\title{
Knowledge, Networks, and Niches
}

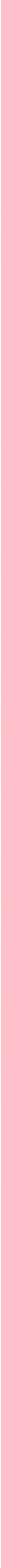




\section{Propositions}

1. The course of Dutch agricultural innovation since the late nineteenth century hinged on expanding government involvement and the high level of self-organization of the Dutch farming population. (this thesis)

2. Proximity to markets should be treated as an explanatory variable when studying the historical development of agricultural innovation. (this thesis)

3. Economists often tend to forget that a lack of growth in production or productivity does not automatically imply a lack of innovative activity.

4. When scholars apply a comparative approach, the similarities between the compared cases are just as important as the differences to clearly identify which determinants are important for the divergence between the compared cases.

5. Coincidence and (mis)fortune are important determinants of one's career.

6. Reading books makes one humble, as it draws attention to the vast knowledge one does not have, the various experiences one has never encountered, or the many places one has never visited.

Propositions belonging to the thesis entitled

'Knowledge, Networks and Niches: Dutch agricultural innovation in an international perspective, c. 1880-1970'

Harm Zwarts,

Utrecht, 20 April 2021 



\section{Knowledge, Networks, and Niches}

Dutch agricultural innovation in an international perspective, c. 1880-1970

Harm Zwarts 


\section{Thesis committee}

\section{Promotors}

Prof. Dr E.H.P. Frankema

Professor of Rural and Environmental History

Wageningen University \& Research

Prof. Dr E.J.V. van Nederveen Meerkerk

Professor of Economic and Social History

Utrecht University

\section{Co-Promotor}

Dr P.J. van Cruijningen

Senior Researcher

Rural and Environmental History Group

Wageningen University \& Research

\section{Other members}

Prof. Dr Ir. J.S.C. Wiskerke, Wageningen University \& Research

Prof. Dr L. van Molle, KU Leuven, Belgium

Dr H. Maat, Wageningen University \& Research

Dr P. Brusse, Utrecht University

This research was conducted under the auspices of the Wageningen School of Social Sciences (WASS). 


\section{Knowledge, Networks, and Niches}

Dutch agricultural innovation in an international perspective, c. 1880-1970

\section{Harm Zwarts}

\section{Thesis}

Submitted in fulfilment of the requirements for the degree of doctor

at Wageningen University

by the authority of the Rector Magnificus,

Prof. Dr A.P.J. Mol,

in the presence of the

Thesis Committee appointed by the Academic Board

to be defended in public on Friday 4 June 2021

at 1:30 p.m. in the Aula. 


\section{Harm Zwarts}

Knowledge, Networks, and Niches: Dutch agricultural innovation in an international perspective, c. 1880-1970,

220 pages.

$\mathrm{PhD}$ thesis, Wageningen University, Wageningen, the Netherlands (2020)

With references, with summaries in English and Dutch

ISBN: 978-94-6395-341-2

DOI: $10.18174 / 517286$ 


\section{ACKNOWLEDGEMENTS}

Although working on a dissertation is very much, as they say, a 'solitary business', I am nevertheless heavily indebted to many people. I am enormously grateful, first and foremost, for the time and effort of my supervisors. Ewout Frankema, Elise van Nederveen Meerkerk, and Piet van Cruyningen together made an outstanding supervision team. Their critical look and constructive feedback always pressed me to search for a deeper understanding, to sharpen my thoughts, and to keep the larger picture in mind. They have had a huge stimulating impact on my personal and academic development, and I think every young scholar deserves such excellent mentors. This dissertation would have been impossible without them.

During the past for years I was also privileged to be part of the Rural and Environmental History Group (RHI) at Wageningen University, which experienced a significant change in personnel during my time there. I want to particularly mention Corinne Boter, Leandre Bulambo, Daniel Gallardo Albarrán, Anton Schuurman, Daniëlle Teeuwen, Pim de Zwart, and Ingrid de Zwarte, and I very much enjoyed sharing a room with Angus Dalrymple-Smith, Michiel de Haas, Kleoniki Alexopoulou, Kate Frederick, Donya Madjdian, and later with Tanik Joshipura, Robert Keenan, and Federica Guardigli. Because of all these people I always very much appreciated working at the office in Wageningen (while Ninon Moreau-Kastler and Elena Díaz Aguiluz had the same effect in Ann Arbor). I am also very thankful for the practical support by Carry Vleeming, Barbara Schierbeek, and Sandra Vermeulen particularly.

I would like to express my gratitude to those who have read earlier drafts of various chapters of this dissertation and who have offered suggestions, corrections, and clarifications though they are not responsible for the shortcomings that remain. I would particularly like to mention (in alphabetical order) Gijs van Campenhout, Michiel de Haas, Jurriën de Jong, Merijn Knibbe, Art-Jan de Kwant, Harro Maat, Ronald Plantinga, Jeroen Touwen, Frank Veraart, and 
Jappe van Zelm. Thanks are also due to Tijmen Groot for his assistance with collecting data, to Jasper Snijders for compiling maps, and to Gerrie Holmer of the Wageningen University Library for her tolerance when I returned books well overdue and when the total number of borrowed books by far exceeded the permitted maximum. Paul Rhode deserves special thanks for the hospitality which I enjoyed during my stay at the University of Michigan during the Fall of 2018 and for being so generous with his time as well as with his thoughts and remarks on my work.

Most significant of all, no doubt, has been the support of Jacomijn. I could not have come this far without her compassion, patience, and tolerance, which are true gifts for which I am forever grateful. She was always understanding and loving in times of doubt, frustration, and tight deadlines, while she also joined me to Michigan without any hesitation. Enjoying life with her is a real privilege. The love we share for each other and for our son points to things far greater than this dissertation.

Harm Zwarts

Utrecht, 2 April 2021 


\section{TABLE OF CONTENTS}

Acknowledgements $i$

Table of Contents iii

List of Figures, Graphs, Tables, and Maps vi

\section{Chapter 1: Introduction}

1.1. Problem Statement and Main Argument 1

1.2. Literature and Concepts 3

1.3. The Dutch case 19

1.4. Approach and Sources $\quad 26$

1.5. Thesis Outline 29

\section{PART I: DUTCH AGRICULTURAL INNOVATION IN CONTEXT}

Chapter 2: Agricultural innovation in its economic context: international trade and economic geography

2.1. Introduction 33

2.2. The development of Dutch agricultural trade 35

2.3. Explaining the growth of Dutch agricultural export 41

2.4. Benefitting from 'geography of innovation' 47

2.5. The shift to 'externally-produced innovation' 52

2.6. Conclusion 56 
Chapter 3: Agricultural innovation in its political context: explaining increased state involvement

3.1. Introduction 58

3.2. Agricultural education until the 1870s 60

3.3. Agricultural research until the 1870s 67

3.4. Explaining the lack of state involvement $\quad 70$

3.5. Explaining the increase in state involvement since the 1870s 76

3.6. The development of state involvement after $1890 \quad 81$

3.7. Conclusion $\quad 88$

PART II: DUTCH AGRICULTURAL INNOVATION AND KNOWLEDGE

EXCHANGE: THREE CASE STUDIES

Chapter 4: Fertilizers and Public Agricultural Consultancy

4.1. Introduction $\quad 89$

4.2. Explaining the increase in fertilizer usage 92

4.3. Diffusing knowledge on artificial fertilizers 99

4.4. Dutch public agricultural consultancy, c. 1890-1960 102

4.5. Dutch public agricultural consultancy in international perspective 106

4.6. J. Elema, State Agricultural Consultant of Drenthe 110

$\begin{array}{ll}\text { 4.7. Conclusion } & 120\end{array}$

\section{Chapter 5: Marketing Cooperatives and Crop Varieties}

5.1. Introduction 122

5.2. The rise of Dutch marketing cooperatives 126

5.3. The internal organisation of the Dutch sugar beet cooperatives 134 
5.4. Sugar beet cooperatives' collaboration on the national level

\section{Chapter 6: Greenhouse Horticulture and Dutch Agricultural Credit Infrastructure}

6.1. Introduction

6.2. The development of Dutch greenhouse horticulture

6.3. Cooperative auctions

6.4. The Agricultural Guarantee Fund

6.5. The knowledge system of the South Holland glass district

\section{Chapter 7: Conclusion}

7.1. Introduction

7.2. Main Argumentation

7.3. Theoretical Contributions

7.4. Limitations and Future Research 


\section{LIST OF FIGURES, GRAPHS, TABLES, AND MAPS}

Figure 1.2. Simplified summary of the innovation adoption process 18

Figure 2.1. Simplified depiction of changing production chains 53

Figure 3.1. Explaining Dutch state intervention since the nineteenth century 86

Graph 2.1. Export in current prices of horticulture, livestock, and arable products, 1846-1926

Graph 2.2. Exports of vegetables, fruits, bulbs, and hedges, 1846-1926 38

Graph 2.3. Exports of potatoes, sugar beets, grains, flax, and seeds, 1846-1926 40

Graph 2.4. Exports of potato starch, beet sugar, bran, and wheat, 1846-1926 41

Graph 2.5. Imports and exports of salpeter, phosphates, potassium fertilizers, and nitrogen fertilizers, 1905-1940

Graph 2.6. Imports and exports of beet seeds and vegetable and flower seeds, 1906-1940

Graph 2.7. Imports and exports of seed potatoes in tons, 1917-1940 51

Graph 4.1. Net imports and exports of fertilizers, 1846-1940

Graph 4.2. Index of prices for artificial fertilizers from the Centraal Bureau relative to prices for wheat, potatoes, and sugar beets, 1900-1940

Graph 4.3. Cooperative purchases of fertilizers in the pasture provinces, the arable provinces, and the mixed provinces, 1904-1924

Graph 4.4. Elema's written and oral advices per year, 1895-1936

Graph 5.1. Acreage of sugar beets, potatoes, and wheat, 1850-1970

Graph 5.2. Sugar beet yields and sugar content at the Puttershoek cooperative

Graph 5.3. Sugar beet acreage in seven areas, 1903-1966

Graph 6.1. Dutch area of hotbeds and greenhouses, 1895-1966

Table 2.1. Index of Dutch agricultural export, 1846-1925

Table 2.2. The knowledge intensification of Dutch agriculture

Table 3.1. Public agricultural colleges in eight nineteenth-century European states

Table 3.2. The main public agricultural institutes in the Netherlands, c. 1870-1950 83

Table 4.1. Use of artificial fertilizers in seven countries, 1870-1985 90

Table 6.1. World greenhouse horticultural area, c. 1900, 1950 and $1970 \quad 165$

Table 6.2. Exports and domestic trade of the three main Westland products, 1939-1960 167

Map 1.1. The six Dutch agricultural areas, c. $1910 \quad 21$

Map 5.1. Location of the seven sugar beet cooperatives, c. $1920 \quad 134$

Map 5.2. Regional variation in sugar beet cultivation in 1920 and $1966 \quad 148$

Map 6.1. Geographical distribution of greenhouse acreage in 1912 and $1930 \quad 162$

Map 6.2. Geographical distribution of greenhouse acreage in $1966 \quad 163$ 


\section{CHAPTER I}

\section{INTRODUCTION}

\subsection{Problem Statement and Main Argument}

The September 2017 issue of the National Geographic magazine contained an article marvelling at the recent performance of Dutch agriculture. How is it possible, the author wonders, that this small, urbanized and densely-populated country is the second world exporter of food? And how is it possible that Dutch farmers increase their yields, while simultaneously cutting on inputs? The author finds the answer to his questions in the innovativeness of Dutch agriculture. With drones, GPS, and artificial intelligence, Dutch arable farmers are able to detect the progress of individual crops and to measure, per square meter rather than per plot, the required inputs. With the future challenges of global agriculture in mind, the National Geographic article concludes that Dutch agricultural innovation 'shows what the future of farming could look like'. ${ }^{1}$ But why is Dutch agricultural innovation world leading?

This study explains the success of Dutch agricultural innovation by looking at its historical roots. Why and how, this study asks, were Dutch farmers able to become among the most innovative in Europe? This question is answered by studying Dutch agriculture between the 1880 s and the 1960s. By 1870, nothing foreshadowed the current success of Dutch agricultural innovation. Despite having been among the most productive and developed of its time during the early modern period, by the nineteenth century Dutch agriculture experienced stagnation. The many small farmers that dominated Dutch agriculture could not follow early forms of mechanization found elsewhere in Europe. Whereas many European governments invested in agricultural education and agricultural research, the Dutch government remained

\footnotetext{
${ }^{1}$ Frank Viviano, 'This tiny country feeds the world. The Netherlands has become an agricultural giant by showing what the future of farming could look like', National Geographic (September 2017). Accessed on https://www.nationalgeographic.com/magazine/2017/09/holland-agriculture-sustainable-farming/, last retrieved on January 21, 2020.
} 
largely uninvolved. With limited public or private investments in research and development (R\&D), knowledge and innovation had to come from abroad: many seeds and artificial fertilizers were imported from Germany, while machineries were mostly of American or British origin. Around 1870 the Netherlands was in no way the agricultural innovator it is today. But Dutch agriculture changed drastically since the 1880s. Specialization accelerated and resulted in an increasing relative importance of high-value products, such as vegetables, root crops, and products processed by the agro-food industry. Productivity growth was achieved not through mechanization but by breeding improved crop varieties and by applying artificial fertilizers on a large scale. Dutch agriculture has ever since been at the forefront of agricultural innovation. How can this rapid transformation since the 1880 s be explained?

To answer this questions, this study concentrates particularly on arable farming, including horticulture. Despite the similarities, a number of differences between Dutch arable farming and Dutch livestock farming make it difficult to combine both in one analysis. Most importantly, whereas Dutch arable farming intensified and specialized at an unprecedented pace since 1870 , in Dutch livestock farming these developments were already launched in earlier decades: the modernization of Dutch livestock farming was not concentrated in the decades around 1900, as was the case with Dutch arable farming, but was spread out more evenly over time.

Focusing on Dutch arable farming, this study comes to the following explanations for the success of Dutch agricultural innovation. This study points out, firstly, that preconditions in the Netherlands were favourable. With their close location to the port of Rotterdam (the main transportation hub of Europe) and urban-industrial agglomerations in Britain and Germany, Dutch farmers could fully profit from the growing demand for higher-value products elsewhere in Europe. Their ongoing specialization brought Dutch farmers at the technological frontier. Secondly, since the late nineteenth century the Dutch government facilitated the Dutch farming 
population in operating at the technological frontier by stimulating agricultural $\mathrm{R} \& \mathrm{D}$, more than was done elsewhere in Europe, where protectionism was often the norm. Publicly funded research institutes and public agricultural consultancy were all vehicles through which knowledge and innovation was exchanged. Thirdly, the high level of self-organization of the Dutch agricultural sector compared to its international counterparts, most clearly visible in the density and variation of Dutch agricultural cooperatives, resulted in a horizontal exchange of knowledge between farmers themselves. The public institutions and the farmer organizations jointly enabled the Dutch agricultural sector, increasingly active in market niches, to adapt foreign innovation to the specific Dutch conditions and, once this high level of specialization had made importing innovation insufficient, to generate innovation and knowledge itself. The public-private networks, in short, provided the knowledge exchange necessary to successfully farm at the technological frontier, which Dutch farmers are still doing today.

\subsection{Literature and Concepts}

With the argumentation that the success of Dutch agricultural innovation can be attributed, simply put, to the ability of the Dutch agricultural sector, through expanding public-private networks, to fully grasp the opportunities presented by the Netherlands' proximity to growing markets of higher-value products in Western Europe, this study contributes to various academic debates, two of which particularly stand out.

\section{Debate I: Factor endowments and ecological constraints}

When aiming to explain innovation, many scholars have pointed at changing relative shares of factors of production. In 1932, Noble Prize laureate Sir John R. Hicks explained innovation by stating that 'a change in the relative price of the factors of production is itself a spur to invention, and to invention of a particular kind - directed to economising the use of a factor which has 
become relatively expensive'. ${ }^{2}$ This proposition has been criticized for being somewhat simplistic and one-dimensional - would firms not want to economize on any production factor, expensive or not? ${ }^{3}$ Daron Acemoglu elaborates on this discussion when introducing the model of 'directed technological change', which prescribes that innovation is not determined by price effects alone. One could innovate, Acemoglu argues, to produce goods of a higher value, thereby achieving what he has coined a 'price effect'. One could also innovate to increase the use of the abundant factor of production, thereby increasing the market, a consequence Acemoglu termed the 'market size effect'. Acemoglu's directed technological change model essentially asserts that innovation is directed towards minimizing the use of the relative expensive production factor (with which Hicks would agree), towards maximizing the relatively cheap production factor, or to both. ${ }^{4}$

Factor endowments have also been applied to the historical development of agricultural innovation. Paul David takes a Hicksian approach when explaining agricultural innovation in nineteenth-century Midwestern US. In a classic 1966 paper, David posed the question why the McCormick reaper, though patented in 1834, was successfully diffused among US farmers only two decades later. In the 1830 s, David finds, US farms were too small to invest in relatively expensive reapers. With farm sizes increasing, a break-even point was reached at which it became profitable to utilize McCormick reapers. David introduced a threshold model that calculates a threshold farm size at which the adoption of McCormick reapers becomes

\footnotetext{
2 J.R. Hicks, The Theory of Wages, 2nd ed. (London: Macmillan, 1963), 124.

${ }^{3}$ Economist W.E.G. Salter, for instance, stated that 'the entrepreneur is interested in reducing costs in total, not particular costs such as labour costs or capital costs. When labour costs rise, any advance that reduces total cost is welcome, and whether this is achieved by saving labour or capital is irrelevant', W. Salter, Productivity and Technical Change (Cambridge: Cambridge University Press 1960), 43-44. Citation found in Nathan Rosenberg, Inside the Black Box: Technology and Economics (Cambridge: Cambridge University Press, 1982), 15.

${ }^{4}$ Acemoglu's work on the model of directed technological change from the 1990s and early 2000s has been synthesized in Daron Acemoglu, "Directed Technical Change," The Review of Economic Studies, 69, no. 4 (October 2002): 781-809.
} 
economically worthwhile, thereby connecting factor endowments - in this case land in the form of farm size - to the adoption of innovation. ${ }^{5}$

The argumentation presented by Hicks and David has been elaborated by Yujiro Hayami and Vernon W. Ruttan. In their comparative analysis of agricultural development in the US and Japan, Hayami and Ruttan argue that farmers innovate to cut one of the production factors that has increased in price relative to the other production factors. In the US, the abundance of land relative to the scarcity of labour has prompted labour-saving innovation, which explains the diffusion of machinery among US farmers. In Japan, on the other hand, land scarcity has generated land-saving innovation, which explains the importance of artificial fertilizers for Japanese farming. Hayami and Ruttan have argued that the economizing on either land or labour induces innovation. ${ }^{6}$

Hayami and Ruttan's 'induced innovation model' has not gone unchallenged. ${ }^{7}$ The model has received criticism for not conforming to historical evidence. In their monograph on biological innovation in nineteenth and twentieth-century US agriculture, Alan L. Olmstead and Paul W. Rhode present two reasons why American biological innovation (innovation concerning living systems, usually plant and cattle breeding) does not fit the induced innovation model. First, American farmers applied biological innovations despite their relatively high

\footnotetext{
${ }^{5}$ Paul A. David, "The Mechanization of Reaping in the Ante-Bellum Midwest," in Industrialization in Two Systems: Essays in Honor of Alexander Gerschenkron, ed. Henry Rosovsky (New York: John Wiley \& Sons, 1966), 3-39. David's explanation for the late diffusion of the McCormick reaper and his threshold model have been criticized by Alan L. Olmstead, who asserted that David's thesis ignores cooperation - farmers purchasing reapers jointly - and does not take into account technological improvements which significantly upgraded the McCormick reaper, which made it more efficient to utilize. Alan L. Olmstead, "The Mechanization of Reaping and Mowing in American Agriculture, 1833-1870," Journal of Economic History, 35, no. 2 (1975): 327-52.

${ }^{6}$ Yujiro Hayami and Vernon W. Ruttan, Agricultural Development. An International Perspective, 2nd ed. (Baltimore: The Johns Hopkins University Press, 1991), 4-5.

${ }^{7}$ Various economists have applied the induced innovation model - also known as 'induced innovation hypothesis' or 'induced innovation theory' - to developed countries, developing countries, and centrally-planned economies, while a number of economic historians have tested the model to long-term historical developments, though mostly doing so for non-agricultural sectors, for instance the textile and mining industry. These studies nuanced or revised the model as it was initially presented by Hayami and Ruttan without altering the model's core elements. For literature reviews, see Colin G. Thirtle and Vernon W. Ruttan, The Role of Demand and Supply in the Generation and Diffusion of Technical Change, 2nd ed. (London and New York: Routledge, 2001).; Bruce M. Koppel, ed., Induced Innovation Theory and International Agricultural Development. A Reassessment (Baltimore: The Johns Hopkins University Press, 1995); Vernon W. Ruttan, Technology, Growth and Development: An Induced Innovation Perspective (New York: Oxford University Press, 2001).
} 
costs. Apparently American farmers did not innovate merely to economize on expensive factors of production. Secondly, the applied biological innovations were land-saving innovations, even though the induced innovation model prescribes that, within the North-American context of land abundance and labour scarcity, farmers would have primarily turned to labour-saving innovations. In short, the successful adoption of biological innovations by American farmers cannot be explained by land/labour ratios alone. ${ }^{8}$

If farmers do not innovate solely to economize on expensive production factors, as Olmstead and Rhode suggest, what then makes farmers innovate? Olmstead and Rhode have found that the many nineteenth-century US farmers migrating into the west had to turn to new crop varieties because traditional crop varieties did not survive on the western soils. Although farmers certainly innovated to increase production, Olmstead and Rhode argue, farmers also did so to secure yields from dropping. Heavily dependent on their direct environment, farmers were often confronted with weeds, diseases, insects or detrimental changes in water availability, soil fertility, climate, and seasonal character. Farmers would go to great lengths to increase control over their direct environment and to lift ecological constraints. ${ }^{9}$

The debate described above consists of two distinct perspectives. On the one hand there is what could be labelled the 'factor endowments approach', voiced most famously by Hayami and Ruttan. This approach argues that agricultural innovation is directed towards economizing on either land or labour. On the other hand one finds what could be called the "ecological approach', represented by Olmstead and Rhode. They argue that agricultural innovations are applied not only to save land or labour, but also to prevent yields from dropping due to weeds, insects, and plant or animal diseases, or due to detrimental changes of location-specific

\footnotetext{
${ }^{8}$ Alan L. Olmstead and Paul W. Rhode, Creating Abundance. Biological Innovation and American Agricultural Development (Cambridge: Cambridge University Press, 2008), 386-402.

${ }_{9}^{9}$ Alan L. Olmstead and Paul W. Rhode, "The Red Queen and the Hard Reds: Productivity Growth in American Wheat, 1800-1940,” Journal of Economic History, 62, no. 4 (2002): 929-66.
} 
variables, such as soil fertility and water availability. In short, farmers in the past also innovated to lift ecological constraints.

Although both approaches have improved our understanding of agricultural innovation, they also contain two problems this study aims to resolve. First, both approaches are largely based on findings from US agricultural history. ${ }^{10}$ Agricultural development in the North American context differs from agricultural development in Western Europe in (at least) two ways. Firstly, in a context of land abundance and low population densities, US farmers operated far from urban markets compared to their Western European counterparts, who operated in a context of land scarcity, higher population densities, and relatively short distances to urban markets. Secondly, US agriculture had a comparative advantage over Western European agriculture. This became particularly clear when the Transport Revolution in the second half of the nineteenth century caused agricultural products from the Americas - and other land abundant regions in Eastern Europe - to invade the Western European food market, with the Agrarian Depression as a consequence. Ever since, Western European farmers have had to react to keep up with their international competitors and to secure their position on international markets.

A second shortcoming of both approaches to agricultural innovation is that they seemingly overlook the significance of access to (foreign) markets. Both approaches do not tell to what extent farmers had to innovate to keep up with commercialization and globalization and to safeguard their access to markets. Market access is key in explaining economic development. Already in 1826 Johann Heinrich von Thünen argued that the proximity of farmers to markets determines the nature of their farming. Close to urban centres, farmers produce goods of a relatively high value, such as dairy or horticultural products, and agriculture is specialized and diverse. In more distant regions, by contrast, farmers produce commodities of a lower value,

\footnotetext{
${ }^{10}$ It should be noted that Hayami and Ruttan compared agricultural development in the US with that of Japan.
} 
with less diversification. Von Thünen's model essentially prescribes that the closer a farmer is located to urban markets, the more he intensifies his farming.

Although Von Thünen's model was consigned to oblivion during the twentieth century, its core principle - economic development is determined by transportation costs and market access - has been revitalized since the early 1990s by economists associated with New Economic Geography, who have argued for a market access explanation for the spatial distribution of economic activity. This New Economic Geography literature argues that, as firms select those locations with minimal transportation costs for their inputs as well as their products, they tend to locate close to markets. This reasoning differs from for instance the Heckscher-Ohlin model, which prescribes that the spatial distribution of economic activity can be attributed to factor endowments. Firms select those locations, this model argues, where the production factor required to produce their goods is most abundantly available. ${ }^{11}$

Although insights from New Economic Geography have been used by economic historians to explain the spatial variation in industrialization, studies applying New Economic Geography to agricultural development in the past have only been appearing since the early 2010s. ${ }^{12}$ Michael Kopsidis and Heinrich Hockmann, for example, explain the sudden increase in agricultural total factor productivity in the German region of Westphalia between 1830 and 1880 by a 'demand push': the rapid expansion of the urban-industrial agglomeration of the Ruhr

\footnotetext{
${ }^{11}$ P.R. Krugman, “Increasing Returns and Economic Geography,” Journal of Political Economy, no. 99 (1991): 483-99. P.R. Krugman and A.J. Venables, "Globalization and the Inequality of Nations," Quarterly Journal of Economics, 4, no. 110 (1995): 857-80. For the connection between Von Thünen's model and New Economic Geography, see P.R. Krugman, A.J. Venables, and Fujita Masahisa, The Spatial Economy: Cities, Regions, and International Trade (Cambridge, MA: MIT Press, 1999), 15-24.

${ }^{12}$ For economic-historical studies with a New Economic Geography approach, see Alexander Klein and Nicholas Crafts, "Making Sense of the Manufacturing Belt: Determinants of US Industrial Location, 1880-1920," Journal of Economic Geography, 2011, 1-33; Joan R. Rosés, "Why Isn't the Whole of Spain Industrialized? New Economic Geography and Early Industrialization, 1797-1910,” Journal of Economic History, 63, no. 4 (December 2003): 995-1022. Nikolaus Wolf, "Endowments vs Market Potential: What Explains the Relocation of Industry after the Polish Reunification in 1918?," Explorations in Economic History, no. 44 (2007): 22-42; Nicholas Crafts and Abay Mulatu, "How Did the Location of Industry Respond to Falling Transport Costs in Britain Before World War I?," Journal of Economic History, 66, no. 3 (September 2006): 575-607.
} 
area. ${ }^{13}$ This study, and others, identify a pattern where agricultural development follows industrialization and urbanization - rather than, as sometimes assumed, the other way around and relate spatial variations in agricultural productivity, intensification, and diversification to proximity to markets. ${ }^{14}$ Yet, the relationship between proximity to markets and agricultural innovation in particular is outside the scope of these studies and has not been sufficiently investigated by economic historians.

The debate about agricultural innovation in the past - why and how did farmers innovate? - is clearly far from closed. This study contributes to this debate in two ways. First, it contributes empirically by studying the Western European case, in particular the Netherlands, which as of yet is understudied. Second, uncovering how market access and commercialization have influenced, determined, or induced agricultural innovation, this study contributes theoretically, by investigating agricultural innovation through a 'Von Thünen lens'.

\section{Debate II: Useful knowledge and the 'agrarian-industrial knowledge society'}

A crucial component of Olmstead and Rhode's explanation for US biological innovation is the access to knowledge. To lift ecological constraints successfully, Olmstead and Rhode propose, farmers must be able to identify the constraints and require the know-how to solve these constraints and to adjust innovations to local circumstances. Innovation can therefore only be successful when knowledge is easy accessible and when information is exchanged smoothly

\footnotetext{
${ }^{13}$ Michael Kopsidis and Heinrich Hockmann, "Technical Change in Westphalian Peasant Agriculture and the Rise of the Ruhr, circa 1830-1880," European Review of Economic History, 14, no. 2 (August 2010): 209-37.

${ }^{14}$ Together with Nikolaus Wolf, Kopsidis has also presented quantitative evidence and constructed an econometric model to show that spatial differences in agricultural productivity across nineteenth-century Prussia were caused by proximity to urban markets, see Michael Kopsidis and Nikolaus Wolf, "Agricultural Productivity across Prussia during the Industrial Revolution: A Thünen Perspective," Journal of Economic History, 72, no. 3 (September 2012): 634-70. Kopsidis and Wolf's econometric model has been applied by Pablo Martinelli to show that agricultural production in Northern Italy and Southern Italy diverged because of a rapid agricultural production growth in Northern Italy after that region industrialized, Pablo Martinelli, "Von Thünen South of the Alps: Access to Markets and Interwar Italian Agriculture," European Review of Economic History, 18, no. 2 (May 2014): 10743.
} 
between farmers and actors developing innovations, such as traders, researchers, and agricultural experiment stations. Knowledge is crucial. ${ }^{15}$

Olmstead and Rhode's emphasis on knowledge resonates with a growing body of literature. Joel Mokyr has added knowledge to the long list of factors explaining the Industrial Revolution. He argues that the Industrial Revolution stemmed from 'useful knowledge', as British eighteenth-century engineers were the first to successfully transform theoretical or 'propositional' knowledge into applied or 'prescriptive' knowledge. The first, Mokyr explains, is knowledge of "what", beliefs about regularities and natural phenomena, the latter is knowledge of "how", instructional knowledge on techniques. ${ }^{16}$ For Mokyr, the diffusion of useful knowledge, resulting from the transformation of propositional knowledge into prescriptive knowledge, was a prerequisite for the Industrial Revolution. ${ }^{17}$

Mokyr comments mainly on artisanal and industrial growth in pre-modern centuries, without applying his argumentation to agricultural development. Since recently, however, his emphasis on useful knowledge is echoed in European agricultural historiography. While Mokyr highlights the importance of the Enlightenment and the Scientific Revolution of the seventeenth and eighteenth centuries for the Industrial Revolution of the nineteenth century, Peter M. Jones uses the cases of Scotland and Denmark to argue that the nineteenth-century Agricultural Revolution in both countries was prepared by what he identifies as an eighteenth-century

\footnotetext{
${ }^{15}$ Alan L. Olmstead and Paul W. Rhode, "Induced Innovation in American Agriculture: A Reconsideration," Journal of Political Economy, 101, no. 1 (1993): 100-118.

${ }^{16}$ Joel Mokyr, The Gifts of Athena. Historical Origins of the Knowledge Economy (Princeton: Princeton University Press, 2002), 4.

${ }^{17}$ Mokyr elaborates on this argumentation in later works. See for instance Joel Mokyr, The Enlightened Economy: An Economic History of Britain 1700-1860 (New Haven and London: Yale University Press, 2012), 9 and 40-62. Mokyr's work can be seen as part of a growing body of literature by economic historians that points at cultural factors (religion, ethics, values, ideas, etc.) to explain economic growth in the past. Examples are David S. Landes, The Wealth and Poverty of Nations. Why Some Are so Rich and Some so Poor (New York and London: W.W. Norton and Company, 1999), Joel Mokyr, A Culture of Growth: The Origins of the Modern Economy (Princeton and Oxford: Princeton University Press, 2017) as well as Deirdre McCloskey's Bourgeois trilogy: Deirdre N. McCloskey, The Bourgeois Virtues: Ethics for an Age of Commerce (Chicago and London: University of Chicago Press, 2006); Deirdre N. McCloskey, Bourgeois Dignity: Why Economics Can't Explain the Modern World (Chicago and London: University of Chicago Press, 2010); Deirdre N. McCloskey, Bourgeois Equality. How Ideas, Not Capital or Institutions, Enriched the World (Chicago and London: University of Chicago Press, 2016).
} 
'Agricultural Enlightenment', during which large landowners increasingly searched, thought, wrote, and corresponded about new ideas concerning farming. Simply put, the Agricultural Enlightenment was to the Agricultural Revolution what the Enlightenment was to the Industrial Revolution. $^{18}$

A point of critique is that Jones mainly studies the eighteenth century, while the transformations of propositional knowledge of 'what' into prescriptive knowledge of 'how' (to paraphrase Mokyr) that significantly spurred agricultural development mainly occurred since the late nineteenth century, when Mendelian genetics (propositional knowledge) resulted in the breeding of improved crop varieties (prescriptive knowledge) and scientific breakthroughs in chemistry (propositional knowledge) resulted in the swift diffusion of chemical fertilizers (prescriptive knowledge). Useful knowledge, as defined by Mokyr, contributed to agricultural development more in the nineteenth and twentieth centuries than it did in preceding centuries.

Whereas Jones has mainly studied knowledge provided by and for the agricultural elite, others have found evidence of useful knowledge diffused among the general farming population. Paul Sharp and Markus Lampe argue that improvements in accounting practices, which they describe as a 'quest for useful knowledge', aided ordinary eighteenth and nineteenth-century farmers in Denmark and northern Germany in achieving efficiency gains. ${ }^{19}$ Merijn Knibbe and Marijn Molema argue in a similar vein, showing that late nineteenth-century improvements in the measurement and documentation of fat percentages of milk by dairy farmers in the Dutch province of Friesland led to the breeding of higher-yielding cows: data gathered by dairy farmers was handed over to breeders, dairy factories, and other experts who could use these provided data in their search for the optimum cattle breed. Useful knowledge,

\footnotetext{
${ }^{18}$ Peter M. Jones, Agricultural Enlightenment. Knowledge, Technology, and Nature, 1750-1840 (Oxford: Oxford University Press, 2016), 215-217.

${ }^{19}$ Markus Lampe and Paul Sharp, "A Quest for Useful Knowledge. The Early Development of Agricultural Accounting in Denmark and Northern Germany," Accounting History Review, 27, no. 1 (2017): 73-99.
} 
Knibbe and Molema show, did not work merely in one direction but was exchanged back and forth. $^{20}$

Knibbe and Molema place this two-sided knowledge exchange in the 'agrarianindustrial knowledge society' into which, they assert, the province of Friesland turned after 1850. Juri Auderset and Peter Moser introduced this concept to explain the capital intensification of European agriculture. Since the mid-nineteenth century, Auderset and Moser argue, an 'ensemble of actors, institutions, discourses, and practices' imposed an 'industrial paradigm' on farmers. This industrial paradigm prescribed that agriculture had to follow the goals, models, and development patterns of the industrial sector. The dominance of this paradigm, Auderset and Moser assert, caused twentieth-century agriculture to scale up massively and resulted in the decline of traditional knowledge and the extinction of traditional ways of farming. ${ }^{21}$

Frank Uekötter, writing a 'Wissensgeschichte' of German agriculture, draws comparable conclusions. Up to the First World War, Uekötter detects an 'agrarian knowledge society' in which experts successfully turned new scientific findings into applicable farming advice, but did so without ignoring the experience, observations, and tacit knowledge of farmers themselves. In subsequent decades, however, new generations of German farmers, more

\footnotetext{
${ }^{20}$ Merijn Knibbe and Marijn Molema, "Institutionalisation of Knowledge-Based Growth: The Case of the DutchFrisian Dairy Sector (1895-1950)," Rural History: Economy, Society, Culture, 29, no. 2 (October 2018): 217-35. ${ }^{21}$ Juri Auderset and Peter Moser, Die Agrarfrage in der Industriegesellschaft. Wissenskulturen, Machtverhältnisse und natürliche Ressourcen in der agrarisch-industriellen Wissensgesellschaft (1850-1950) (Cologne: Böhlau Verlag, 2018), 11 and 20. For an earlier explanation of their concept, see Peter Moser, Juri Auderset, and Beat Bächi, "Die agrarisch-industrielle Wissensgesellschaft im 19./20. Jahrhundert: Akteure, Diskurse, Praktiken," in Geschichte im virtuellen Archiv. Das Archiv für Agrargeschichte als Zentrum der Geschichtsschreibung zur ländlichen Gesellschaft, ed. Beat Brodbeck, Martina Ineichen, and Thomas Schibli, Studien und Quellen zur Agrargeschichte 3 (Baden: Hier und Jetzt Verlag, 2012), 21-38. It should be mentioned that the notion of twentieth-century farming being industrialized is certainly not new nor only studied by European historians. American historian Deborah Fitzgerald, for instance, has described how Montana wheat farming changed dramatically through the growing impact of experts, who diffused an 'industrial ideal' of 'factoryizing' farms, an ideal which contributed to the mechanization, rationalization and the scaling-up of Montana wheat farming. American agricultural historian J.L. Anderson elaborates on Fitzgerald's notion of an 'industrial ideal' when showing that corn farmers in post-Second World War Iowa had to industrialize their farming (applying machineries and agrochemicals), with the disappearance of traditional family farming as a consequence. Deborah Fitzgerald, Every Farm a Factory. The Industrial Ideal in American Agriculture (New Haven and London: Yale University Press, 2003), 188-89.; J.L. Anderson, Industrializing the Corn Belt. Agriculture, Technology, and Environment, 1945-1972 (DeKalb: Northern Illinois University Press, 2009), 191-96.
} 
receptive to innovation, (purposefully or not) left their central place within this knowledge network to become (passive) knowledge recipients, consequently ceasing their contribution to knowledge themselves. As a result, Uekötter argues, the expertise of the German individual farmer diminished (a 'Wissenserosion') and knowledge once taking into account the complexities and local characteristics of farming was replaced for simplistic and generalizing principles which greatly increased German agricultural productivity but did so at the cost of, for instance, biodiversity. ${ }^{22}$

Scholars clearly hold opposing views on the role of knowledge in agricultural development. Some, including Olmstead and Rhode and Jones, hold a positive view of the knowledge intensification of agriculture and see Mokyrian useful knowledge as essential for the structural transformation agriculture experienced in the past two centuries. Others, including Uekötter and Auderset and Moser, hold a more negative view. For them, knowledge intensification followed from the industrial paradigm being imposed on farmers, who consequently saw their agency reduced and were confined to a marginal role.

A number of counterarguments can been given against this negative view of agriculture's knowledge intensification. Firstly, this view seemingly overlooks the political emancipation of farmers. Since the late nineteenth century increased self-organization and suffrage expansion gradually improved the influence of farming populations on public agricultural policy. For example, Jonathan Harwood has found that the Bavarian government, fearing political radicalization of its peasantry, invested in 'peasant-friendly' plant breeding, i.e. plant breeding directed towards the needs of small farmers. ${ }^{23}$ Instead of being uninvolved,

\footnotetext{
${ }^{22}$ Frank Uekötter, Die Wahrheit ist auf dem Feld. Eine Wissensgeschichte der deutschen Landwirtschaft, 3rd ed., Umwelt und Gesellschaft 1 (Göttingen: Vandenhoeck \& Ruprecht, 2012), 43, 270, and 435-36.

${ }^{23}$ Jonathan Harwood, "Why Did Nineteenth-Century States Establish Agricultural Research Stations? The Origins of the South German Plant-Breeding Stations c. 1900," in Integration through Subordination. The Politics of Agricultural Modernisation in Industrial Europe, ed. Peter Moser and Tony Varley, Rural History in Europe 8 (Turnhout: Brepols, 2013), 246. Elsewhere, Harwood argues that publicly-funded research institutes, experiment stations, and extension services were established in late nineteenth-century Prussia mainly to prevent social and political unrest among peasants. See Jonathan Harwood, "Research and Extension in Political Context: Rural Unrest and the Origins of the Prussian Chambers of Agriculture," in The State and Rural Societies. Policy and
} 
farmers often had their share through their societal and political voice. Secondly, expert knowledge was not always imposed upon farmers, but was in many instances produced by cooperatives and other farmer organizations. These organizations reached their objective of granting their members a secure position on markets through various means, including the distribution of expert knowledge. In addition, experts and other actors within knowledge networks typically came from farming families, shared a common rural background, and had often received the same agricultural training as farmers. ${ }^{24}$ In sum, the division between farmers and experts was not as sharp as sometimes assumed.

Ofcourse, this is all not to say that every twentieth-century farmer applauded the many changes he experienced during his lifetime. Many had huge difficulties adjusting. However, this study shows that the industrial paradigm did not travel exclusively from experts to farmers, but went to and fro among those involved and was thus not merely a template into which farmers were coercively forced. For many, 'industrializing' their farming was a way to cope with international competition, to keep up with productivity growth in other sectors of the economy, and to meet higher consumer demands. Although the industrial paradigm proved devastating for some, it was a mode of survival for others.

Education in Europe 1750-2000, ed. Nadine Vivier, Rural History in Europe 4 (Turnhout: Brepols, 2008), 136. For Harwood's critique on Auderset and Moser's monograph and concept, see Jonathan Harwood, "Review Die Agrarfrage in der Industriegesellschaft: Wissenskulturen, Machtverhaeltnisse und natürliche Ressourcen in der agrarisch-industriellen Wissensgesellschaft (1850-1950) by Auderset and Moser," Agricultural History, 93, no. 1 (Winter 2019): 191-93.

${ }^{24}$ Anton Schuurman asserts that Dutch public agricultural policy was shaped by a complex of relationships between public and private agents, which he coins the 'agricultural institutional matrix'. The agents within this matrix, usually active within research institutes, cooperatives, farmer organizations, and the ministry of agriculture, shared a common cultural, economic, societal, and educational background. Anton Schuurman, "Agricultural Policy and the Dutch Agricultural Institutional Matrix during the Transition from Organized to Disorganized Capitalism," in Integration through Subordination. The Politics of Agricultural Modernisation in Industrial Europe, ed. Peter Moser and Tony Varley, Rural History in Europe 8 (Turnhout: Brepols, 2013), 67-69. For a more detailed explanation of the concept of the agricultural institutional matrix, see Anton Schuurman, "The Construction of Dutch Agriculture Inc: From Liberal Capitalism to Organized Capitalism" (ESSHC, Lisbon, 2008). 
As this study deals with agricultural innovation, it is important to specify what exactly this refers to. Scholars of innovation have not found consensus about the concept's demarcation. ${ }^{25}$ An early and classic definition was introduced in 1934 by Joseph Schumpeter, who argued that an innovation is at least one of the following five points: the introduction of a new good; the introduction of a new method of production; the opening of a new market; the conquest of a new source of supply of raw materials or half-manufactured goods; or the carrying out of the new organization of any industry. ${ }^{26}$ Central to Schumpeter's conceptualization is that innovations are not mere inventions. An invention comes into being when a new idea, method or good emerges for the first time, only turning into an innovation once brought into practice. 'While invention is an act of intellectual activity', as one scholar paraphrases Schumpeter, 'innovation is an economic decision: a firm applying an invention or adopting invention.' Innovations are inventions, but inventions do not always become innovations. ${ }^{27}$

Schumpeter's conceptualization also relies heavily upon the distinction between 'process innovation' and 'product innovation'. The first concerns improvements to the processing of products (through efficiency gains, cost reductions, production or productivity enhancements, etc.), while the latter refers to the introduction of an entirely new product or to improvements of an existing product. ${ }^{28}$ Also including practices, institutions, and organizations, innovation can be seen as either 'hardware', 'software', or 'orgware', with hardware referring to the material equipment (new machinery, devices, practices), software concerning knowledge (manuals, modes of thinking, know-how), and orgware involving new organisations and

\footnotetext{
${ }^{25}$ One literature review claims to have collected no less than 60 different definitions. Anahita Baregheh, Jennifer Rowley, and Sally Sambrook, "Towards a Multidisciplinary Definition of Innovation," Management Decision, 47, no. 8 (2009): 1323-39.

${ }^{26}$ Joseph A. Schumpeter, The Theory of Economic Development. An Inquiry into Profits, Capital, Credit, Interest, and the Business Cycle, trans. Redvers Opie, 3rd ed., Harvard Economic Studies 46 (Cambridge, MA: Harvard University Press, 1949), 66.

${ }^{27}$ Benoit Godin, Models of Innovation. The History of an Idea (Cambridge, MA: The MIT Press, 2017), 61.

${ }^{28}$ Schumpeter, The Theory of Economic Development. An Inquiry into Profits, Capital, Credit, Interest, and the Business Cycle, 66.
} 
institutions. ${ }^{29}$ These different forms of innovations can never be fully disentangled. 'Hardware' innovation often demands 'software' and 'orgware' innovation, or vice versa, while 'process innovation' and 'product innovation' might overlap in a similar vein.

All these concepts refer to innovation in general rather than agricultural innovation specifically. Keith Pavitt has categorized agricultural innovation as 'supplier-dominated' innovation, because farmers do not have the resources to do 'in-house' $R \& D$ and are thus, more than other sectors of the economy, heavily dependent on suppliers, extension services, and research institutes for their knowledge and technology. ${ }^{30}$ Olmstead and Rhode also distinguish between agricultural innovation and general innovation by arguing that the former does not have a high degree of portability. A new crop variety, for example, might grow in one particular region but might fail completely in another, where soil conditions, water availability, and other ecological circumstances are different. Many agricultural innovations, Olmstead and Rhode state, 'must be fine-tuned and harmonised to the specific climatic and soil conditions of a given local, maybe even a given plot of land' ${ }^{31}$ Agricultural innovation, and the knowledge required to adopt it, do not travel easily.

Another important characteristic that Olmstead and Rhode highlight is the effect agricultural innovation potentially has. Often being human interventions in biological processes, agricultural innovation may solve problems while simultaneously causing new ones; farmers often have to apply new innovations to solve problems caused by older innovations. Olmstead and Rhode use the concept of the 'Red Queen's dictum' to describe this constant need

\footnotetext{
${ }^{29}$ Ruud Smits, "Innovation Studies in the 21st Century: Questions from a User's Perspective," Technological Forecasting and Social Change, 69, no. 9 (December 2002): 861-83.

30 Apart from supplier-dominated innovation, which also includes for instance house building, the Pavitt Taxonomy, as it is known, also distinguishes scale-intensive innovation (for instance industrial bulk production), science-based innovation (for instance medicine and chemicals), specialised-suppliers innovation (for instance machinery and instruments), and a specific category for 'government and utilities' (for instance defence, energy, communications, and transport). Keith Pavitt, "Sectoral Patterns of Technical Change: Towards a Taxonomy and a Theory," Research Policy, 13, no. 6 (1984): 354 and 370.

31 Alan L. Olmstead and Paul W. Rhode, "Conceptual Issues for the Comparative Study of Agricultural Development," in Agriculture and Economic Development in Europe Since 1870, ed. Pedro Lains and Vicente Pinilla (London: Routledge, 2009), 43.
} 
for innovation. Derived from a scene in Lewis Carrol's Through the Looking Glass in which the Red Queen explains to Alice that one has to keep running to stay in the same place, the 'Red Queen's dictum' was first introduced in evolutionary biology to refer to the evolutionary arms race in which species evolve constantly to avoid extinction. ${ }^{32}$ Farmers are also tied by this Red Queen's dictum: they have to innovate continually to maintain yields. Farmers, Olmstead and Rhode note, 'have to run fast just to stay in one spot'. ${ }^{33}$

As noted, the 'supplier-dominated' character of agricultural innovation causes farmers to be heavily dependent on other actors when adopting innovations. Yet, the location-specific nature of agricultural innovation and the struggle with the Red Queen's dictum also give the individual farmer a pivotal role. The adoption process of agricultural innovation, summarized below in Figure 1.2, can in its most simplified and stylized form be understood in three stages. Firstly, in the invention stage an innovation is developed by, for instance, a firm or research institute. Hereafter the innovation, as well as the knowledge required to use it, is diffused by, among others, traders, agents, advisors, and cooperatives in the diffusion stage. The last stage is crucial for the success of agricultural innovation; during this implementation and adaption stage the location-specific nature of farming becomes evident, as in this stage farmers have the difficult task to adapt the innovation to local circumstances and to actually make the innovation function.

\footnotetext{
${ }^{32}$ The first usage of the Red Queen's dictum (sometimes also called hypothesis, race, or effect) in scholarly work was in Leigh Van Valen, “A New Evolutionary Law,” Evolutionary Theory, 1 (1973): 1-30.

${ }^{33}$ Olmstead and Rhode, "Conceptual Issues for the Comparative Study of Agricultural Development," 43. For Olmstead and Rhode's use of the Red Queen's dictum, see Olmstead and Rhode, "The Red Queen and the Hard Reds: Productivity Growth in American Wheat, 1800-1940."
} 
Figure 1.2. Simplified summary of the innovation adoption process

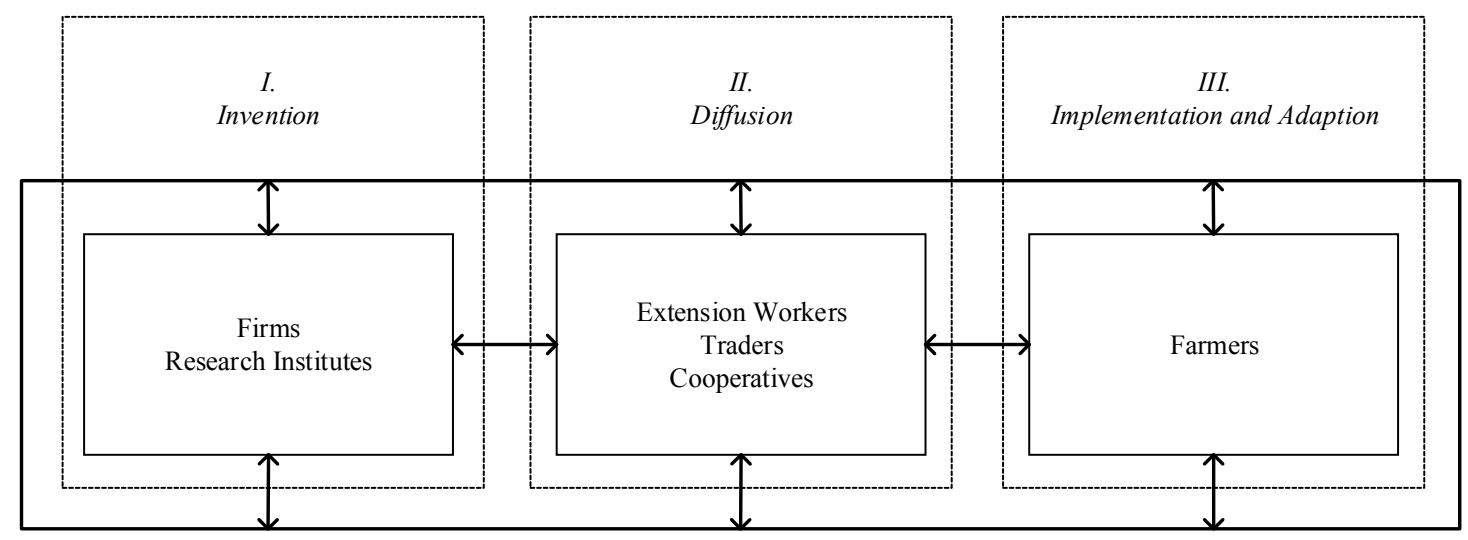

This three-stage innovation adoption process is loosely based on the six-stage 'innovationdecision process' presented by Everett M. Rogers in his classic monograph Diffusion of Innovations. The different stages in the process, Rogers notes, 'are somewhat arbitrary in that they do not always occur in exactly the order shown here, and certain stages may be skipped in the case of certain innovations. ${ }^{34}$ The same goes for the three stages in Figure 1.2. Because an innovation might not function properly or cause new problems, farmers have to communicate with each other and with other actors to discuss improvements, to find solutions, or to provide feedback. Moreover, farmers are most often the ones expressing the need for innovation and identifying where and when innovation is needed. As such, farmers are the end as well as the starting point of a fluid, multi-directional, and on-going knowledge exchange from one agent, or one stage within the process, to another.

The knowledge exchange between different actors, then, represented in Figure 1.2 in the bold line, might go from firms and research institutes (invention stage) to extension workers, traders, and cooperatives (diffusion stage) to arrive at the farmers (implementation and adaption stage), but could just as well work in the opposite direction, while some of the exchange could

\footnotetext{
${ }^{34}$ Everett M. Rogers, Diffusion of Innovations, 5th ed. (New York: Free Press, 2003), 138. After Rogers, many scholar of innovation have developed various versions of the innovation adoption process. For a historical overview, see Godin, Models of Innovation. The History of an Idea, 43-47.
} 
even occur directly between farmers and research institutes or firms. In practice, though, the literal or figurative distance between farmers on the one hand and firms and research institutes on the other makes that most of the knowledge exchange occurs through mediator agents. The innovation capacity of individual farmers, to conclude, is largely determined by the presence of expanding and tightening networks, consisting of various mediator agents, through which knowledge is smoothly exchanged.

\subsection{The Dutch case}

The focus of this study is the Netherlands. Being a river delta, the Netherlands consists of various regions with ranging soil types, ranging farming systems, and ranging agricultural developments. This study follows other Dutch historical literature in that it identifies six distinct agricultural areas (see Map 1.1). ${ }^{35}$ The first distinct agricultural area is known as the pasture regions and includes the vast majority of the western provinces of North Holland, South Holland, and Utrecht, as well as large parts of the north-western province of Friesland. Since the Middle Ages agriculture in these regions was heavily specialized in dairy farming. The second area includes the sea clay regions, which are found particularly in the north-eastern province of Groningen and the south-western province of Zeeland. With fertile soils, these regions had long been specialized in cash crop production, cultivating potatoes, sugar beets, grains, and vegetables, which were often traded to urban centres such as the Holland or Flemish cities. Most parts of the country in the south and the east, the bulk of the provinces of Drenthe, Overijssel, Gelderland, Noord-Brabant, and Limburg, are the sandy regions, the third area. These inland regions were in general less fertile and less developed than the other Dutch regions. It was only during the nineteenth century that farmers in these regions abandoned

\footnotetext{
${ }^{35}$ While the Dutch government recognized twelve agricultural regions during the nineteenth century, by 1910 this was brought back to six. This 1910 division was used in Dutch agricultural statistics until the late 1950s. Jan Bieleman also follows the 1910 division in his monograph on Dutch agricultural history. J. Bieleman, Boeren in Nederland. Geschiedenis van de landbouw 1500-2000 (Amsterdam: Boom, 2008), 38-39.
} 
mixed farming and gradually specialized in either livestock farming (usually dairy, poultry, or pig husbandry) or arable farming.

The sandy dunes along the western coastline comprise the fourth distinct area. Close to the urban centres of Holland, farmers in these regions had produced vegetables and other horticultural products since pre-modern times. Further specialization, with the rise of flower cultivation (tulips, most famously) and greenhouse horticulture, started in the nineteenth century. The fifth area includes all the river clay areas, found in the centre of the country along the shores of the main rivers as well as in southern most part of the south-eastern province of Limburg. ${ }^{36}$ These river clay areas specialized in fruit cultivation, containing many orchards. A set of small regions in the northern provinces of Groningen, Drenthe, and Overijssel are the Veenkoloniën (literally 'peat colonies'), comprising the sixth area. Here, peat extraction was finalized as late as the nineteenth century, and in some instances even only in the early twentieth century, after which it was turned into relatively unfertile arable land where cultivation of cash crops was feasible with intensive fertilizing only.

\footnotetext{
${ }^{36}$ The southern part of Limburg consists of loess. Dutch agricultural statistics nevertheless classified it as part of the river clay areas.
} 


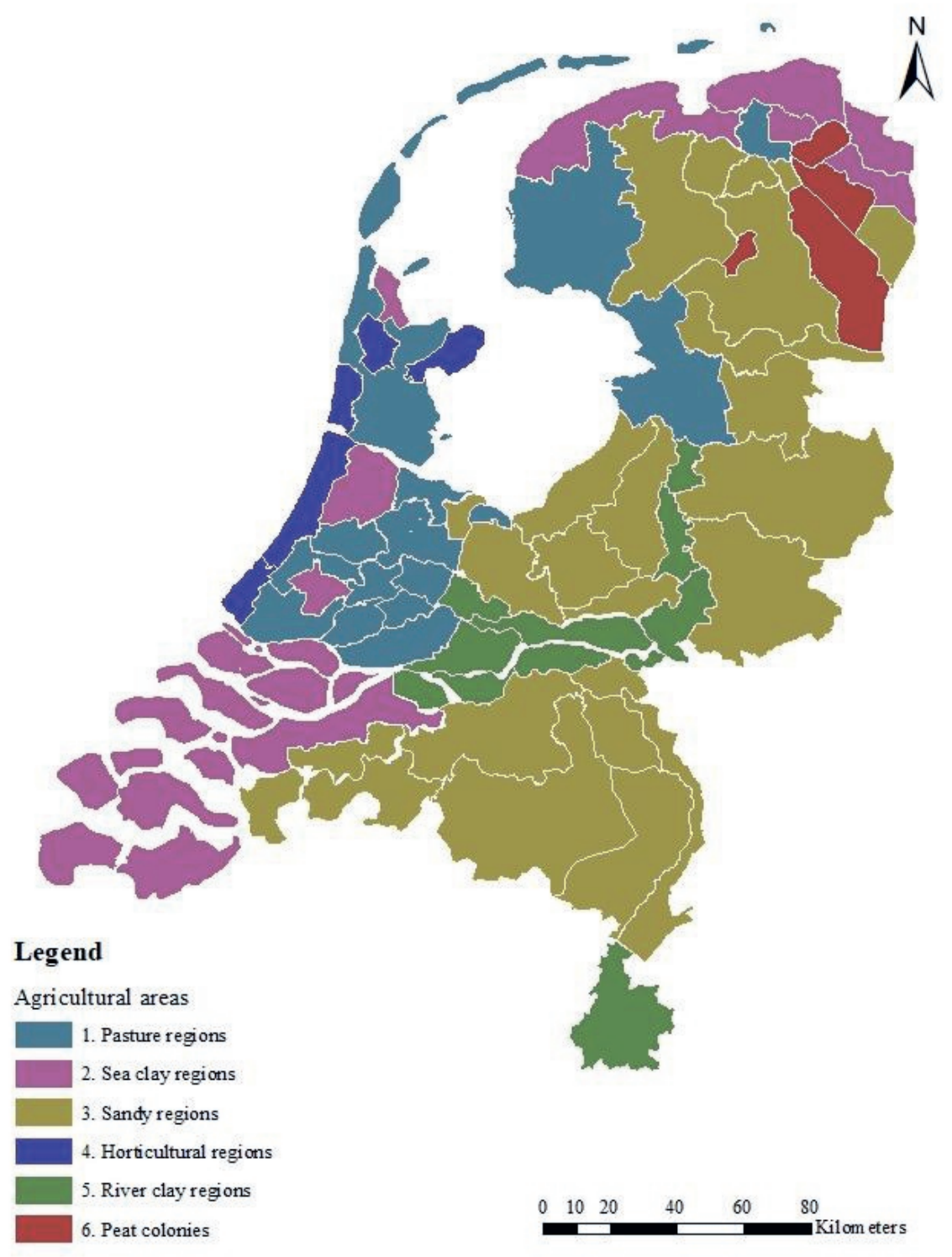

Despite the variation in these Dutch agricultural areas, all with their distinct historical development paths, some general patterns can still be discerned. Together with Britain, Belgium, and Denmark, the Netherlands was part of a region in Europe where yields increased steadily since the fifteenth century. ${ }^{37}$ This production growth in the North Sea area has been

${ }^{37}$ B.H. Slicher van Bath, Yield Ratios, 810-1820, AAG Bijdragen 10 (Wageningen, 1963), 16. 
attributed to an intensified usage of land, caused by urbanization and increasing population densities. ${ }^{38}$ By 1870 , only Belgium had a higher production per hectare and only Denmark and Great Britain had a higher production per farmer. ${ }^{39}$

Despite being among the most developed agricultural sectors of Europe, Dutch nineteenth-century agriculture has not always been assessed positively. Contemporaries noted that expanding export opportunities - especially the repeal of the British Corn Laws in 1846 launched a period of progress - made Dutch farmers 'rich while sleeping', as there was supposedly little need to innovate. ${ }^{40}$ Historians have argued that production and productivity growth generally stagnated - the 75 per cent increase in land productivity between 1830 to 1875 , calculated by economist Jan-Pieter Smits, is attributed to the sandy areas (the third region in Map 1.1) catching up with the more developed regions - and that Dutch agriculture was overall unable to improve its competitiveness, as shown, for instance, by the declining share of Dutch butter on the British market at the expense of higher-quality Danish butter. Since the 1870s, improvements in transportation introduced new competitors on the European markets and resulted in the Agrarian Depression (c. 1873-1896), which slowed down Dutch agricultural production growth. ${ }^{41}$

After the Agrarian Depression, Dutch agricultural production growth accelerated again. This growth was caused by a more intensive use of inputs, particularly fertilizers and animal feed; in 1807 , these inputs amounted to $23 \%$ of gross production, a figure only slightly increased to $24 \%$ by 1880 . Hereafter, the share of inputs increased rapidly to $37 \%$ in 1900 and

\footnotetext{
${ }^{38}$ B.H. Slicher van Bath, The Agrarian History of Western Europe, AD 500-1850, trans. Olive Ordish (London: Edward Arnold (Publishers) Ltd, 1963), 239-43. J.L. van Zanden, "The Development of Agricultural Productivity in Europe 1500-1800," NEHA-Jaarboek voor economische, bedrijfs- en techniekgeschiedenis, 61 (1998): 66-85.

39 J.L. Van Zanden, The First Green Revolution. The Growth of Production and Productivity in European Agriculture 1870-1914, Research Memorandum 1988-42 (Amsterdam: Vrije Universiteit, 1988), 8.

40 J.L. van Zanden and Arthur van Riel, The Strictures of Inheritance: The Dutch Economy in the Nineteenth Century, trans. Ian Cressie (Princeton, NJ: Princeton University Press, 2004), 201.

41 Jan-Pieter Smits, "Technological Change, Institutional Development and Economic Growth in Dutch Agriculture, 1870-1939," in Agriculture and Economic Development in Europe Since 1870, ed. Pedro Lains and Vicente Pinilla (London: Routledge, 2009), 100. Van Zanden and Van Riel, The Strictures of Inheritance: The Dutch Economy in the Nineteenth Century, 201-3.
} 
to $45 \%$ in $1913 .{ }^{42}$ Together with Belgium, Denmark, and Germany (Britain, once the most advanced agricultural sector, lagged behind), the Netherlands experienced, as J.L. van Zanden puts it, the 'First Green Revolution', as these countries took the lead in increasing land and labour productivity, applying inputs more intensively, and rearranging the institutional landscape, particularly with farmer-led cooperatives. ${ }^{43}$ In the Netherlands, farmers joined these cooperatives to profit from economies of scale, jointly organizing the purchase and distribution of their inputs and products. The membership of agricultural cooperatives increased rapidly, from $4 \%$ of the Dutch farming population in 1893 to $30 \%$ in $1904,44 \%$ in 1910 , and $90 \%$ in $1950 .{ }^{44}$

The structural transformation of the Dutch agricultural sector after the Agrarian Depression also included a rapid specialization and diversification. Dutch farmers had reached relatively high levels of specialization in pre-modern centuries. The proximity to Amsterdam, Europe's main staple market for grain since the sixteenth century, enabled Dutch farmers to specialize in livestock farming or in the production of vegetables, horticultural products, or 'industrial' crops used as raw materials in (proto)industry, for instance madder, hop, and hemp. ${ }^{45}$ Since the late nineteenth century, economic growth and rising living standards in many parts of Europe increased the demand for higher-valued products and accelerated specialization and diversification. ${ }^{46}$ Dutch farmers simultaneously integrated heavily into the agro-food industry, the expansion of which since the late nineteenth century mainly occurred in the

\footnotetext{
${ }^{42}$ Van Zanden and Van Riel, The Strictures of Inheritance: The Dutch Economy in the Nineteenth Century, 284.

43 J.L. van Zanden, "The First Green Revolution: The Growth of Production and Productivity in European Agriculture, 1870-1914," Economic History Review, 44, no. 2 (1991): 230, 235-38.

${ }^{44}$ Van Zanden and Van Riel, The Strictures of Inheritance: The Dutch Economy in the Nineteenth Century, 28590 .

${ }^{45}$ Jan de Vries and Ad van der Woude, The First Modern Economy: Success, Failure, and Perseverance of the Dutch Economy, 1500-1815 (Cambridge: Cambridge University Press, 1997), 225.

${ }^{46}$ Merijn Knibbe, Agriculture in the Netherlands 1851-1950. Production and Institutional Change (Amsterdam: NEHA, 1993), 138.
} 
processing industry, which, for instance, extracted sugar from beets, starch from potatoes, and made cardboard from straw. ${ }^{47}$

The progress that Dutch farming experienced after the Agrarian Depression was stopped by the First World War, which paused international market integration and blocked the imports of necessary inputs, such as artificial fertilizers and animal feed. Although experiencing a short boom shortly after the First World War, one particular weakness of the Dutch agricultural sector came to light during the 1920 s. The nearly insatiable (domestic or foreign) food markets and the structure of the Dutch agricultural sector - its export-orientation, the high density of agricultural cooperatives, and the relatively large processing industry - had made small-scale farming feasible. Although Dutch small farmers could secure a living with just a few acres of land during upturns, in times of economic hardship they easily fell into poverty and were unable to mechanize and scale up, as was done elsewhere. ${ }^{48}$

The dominance of small-scale farming in the Netherlands became problematic when agricultural prices fell during the second half of the 1920s, but particularly during the Great Depression of the 1930s. As a result, the Dutch government traded its long-held laissez-faire policy for protectionism and regulation, guaranteeing fixed prices above world market levels for wheat (since 1931) and later for other agricultural products. Between 1933 and 1936 the government paid 200 million Dutch guilders annually, on a total agricultural income of 400 to 500 million guilders and on a total state budget of 1 billion guilders. To safeguard domestic food security, particularly the provision of grains, the state restricted the cultivation of certain cash crops which had been produced mainly for foreign markets. This government intervention into Dutch agriculture intensified the links between agricultural organizations, political parties,

\footnotetext{
${ }^{47}$ Although the Netherlands lagged behind in industrialization compared to other European countries, its agrofood industry was well-developed and could keep up with production growth found elsewhere. See Ewout Frankema, Pieter Woltjer, and Jan-Pieter Smits, "Changing Economic Leadership. A New Benchmark of Sector Productivity in the United States and Western Europe, ca. 1910," Low Countries Journal for Social and Economic History, 10, no. 3 (2013): 80-113.

${ }^{48}$ Knibbe, Agriculture in the Netherlands 1851-1950. Production and Institutional Change, 179-80. Bieleman, Boeren in Nederland. Geschiedenis van de landbouw 1500-2000, 461-81.
} 
and the Dutch ministry of agriculture. The political subsystem resulting from this public-private collaboration, known as the 'Green Front', dominated Dutch public agricultural policy in the following decades. ${ }^{49}$

The bottlenecks obstructing further growth were largely solved after the Second World War. The Marshall Aid issued by the US in the late 1940s was used to import agricultural machinery and to expand agricultural research, consultancy, and education. Mechanization finally breached the limits of labour productivity when Dutch agriculture scaled up, which only occurred after the enormous exodus of many small farmers to other sectors and after the large reallocation of scattered plots into more efficiently organized plots (known as the ruilverkaveling). The Dutch government, meanwhile, continued to guarantee prices above world market levels, a policy extended by the European Economic Community after $1957 .{ }^{50}$

In the past two centuries, to conclude, the Dutch agricultural sector transformed dramatically and increased productivity immensely: Dutch agricultural labour productivity, for example, increased almost 43 -fold between 1810 and $2000 .{ }^{51}$ Although large parts of this expansion was achieved after the Second World War, the foundations of this expansion, as well as most of its characteristics (its export orientation, the high levels of specialization and diversification, the public-private collaboration within the 'Green Front', the many farmer-led cooperatives, and the expanding agro-food industry) were established well before the Second World War. Although the success of Dutch agricultural innovation became most apparent after 1950 , for its historical roots we will have to go further back.

\footnotetext{
49 J.L. van Zanden and R.T. Griffiths, Economische geschiedenis van Nederland in de 20e eeuw (Utrecht: Het Spectrum, 1989), 72-79. J.L. van Zanden, The Economic History of the Netherlands 1914-1915. A Small Open Economy in the "long" Twentieth Century, Contemporary Economic History of Europe (London and New York: Routledge, 1998), 58-60.

${ }^{50}$ Van Zanden, The Economic History of the Netherlands 1914-1915. A Small Open Economy in the "long" Twentieth Century, 141-42.

${ }^{51}$ Merijn Knibbe, "Landbouwproductie en -productiviteit, 1807-1997," in Nationaal goed. Feiten en cijfers over onze samenleving, (ca.) 1800-1999, ed. Ronald van der Bie and Pit Dehing (Amsterdam: Stichting beheer IISG, 1999), 37.
} 


\subsection{Approach and Sources}

Aiming to explain why and how Dutch arable farmers came to be successful innovators, this study deals with a wide variety of determinants. Many of the concepts central to this study, such as 'useful knowledge' and 'knowledge exchange', are highly intangible and elusive and are not easily grasped in general trends or quantitative measures. This study does therefore not apply one single methodology, but combines various approaches to capture the subject in its full depth and to avoid reducing the complexity of the matter - which, admittedly, always happens to some extent when studying the past.

The main part of this inquiry is conducted through case studies. This is done by focusing on specific innovations or on particular subsectors within Dutch agriculture. Chapter 4 is a case study of artificial fertilizers, while chapter 5 focuses on plant breeding (particularly sugar beet production) and chapter 6 gives special attention to greenhouse horticulture. These cases characterize the twentieth-century development of Dutch arable farming: artificial fertilizers and new plant varieties were, no doubt, the main innovations prior to the post-Second World War mechanization of Dutch farming - and also remained highly important hereafter. In fact, Dutch arable farmers, as chapter 4 will show, had the highest usage of artificial fertilizers per hectare worldwide. The Dutch greenhouse horticultural sector - the growth of which, as we will see in the sixth chapter, has been referred to as the 'Greenhouse Revolution' - was by far the largest of its kind worldwide and was arguably the pinnacle of Dutch agricultural innovation.

The case studies in chapters four to six are largely actor-based. Despite the lack of sources making it impossible to study farmers individually, archival records of other actors have sometimes survived and can be used to gain more insight in the knowledge exchange between farmers and other actors. Chapter 4 therefore discusses the work of one single public agricultural consultant: Jacob Elema, the main agricultural consultant in the province of Drenthe during the first decades of the twentieth century. Elema's personal archive, including 
his correspondence with individual farmers, grants insight into the organization of knowledge flows, particularly knowledge concerning artificial fertilizers, which were of upmost importance for the development of Drenthe's farming. Chapter 5 zooms in on seven sugar beet cooperatives. These cooperatives, through which farming shareholders could process their beets into sugar, gave their members access to (international) markets and to knowledge and technology that would otherwise have remained inaccessible. The records of these sugar beet cooperatives, mostly minutes of shareholder meetings, show how farmers' networks functioned and how knowledge was diffused, particularly, as in the case of the sugar beet cooperatives, knowledge about beet seeds.

Chapter 6, in aiming to explain the rapid increase in greenhouse acreage, especially during the Interbellum and between the early 1950 s to the late 1960s, focusses on a body of actors rather than on one individual actor or on a small set of actors. Firstly, attention is given to cooperative auctions, which functioned in such a way, chapter 6 will argue, that Dutch horticultural farmers had quick access to international markets and could swiftly reinvest their earned cash. Secondly, to see how the capital-intensive growth of Dutch greenhouse horticulture was financed, attention will be given to the Dutch agricultural credit infrastructure, consisting mainly of cooperative rural banks and state guarantee funds. The geographical focus of chapter 6 is the South-Holland glass district, a triangle roughly between The Hague and Rotterdam where the bulk of the Dutch greenhouse acreage was located.

Following the need to place the case studies in chapters 4,5 , and 6 into a larger perspective, the case-study approach is accompanied by an analysis on the national level. Although the analysis on the national level is, admittedly, partly source-driven - there is an abundance of archival material on the national level - it also improves our understanding of the growing grip of the central government: knowledge and innovation, this study shows, were increasingly produced by public institutes, while the networks that diffused knowledge and 
innovation were largely - though, important to note, certainly not exclusively - organized topdown, through public consultancy and public education.

This analysis on the national level also enables a comparative approach, which works in two ways. Firstly, an international comparison puts the evidence and findings from the Dutch case into perspective, comparing, when information from secondary literature allows it, with the historical examples of Belgium, Germany, Denmark, Britain, and, in some cases, the United States. Each of these, to state the obvious, shared similarities with the Dutch case while also differing on essential points. The Netherlands and Denmark, to start with, were not as heavily industrialized as Belgium, Britain, and Germany. The Netherlands and Belgium were typical land-scarce countries, while (rural) population densities were lower in Britain, Denmark, and Germany, and much lower in the United States. In the end, all these countries 'industrialized' their agriculture, be it during different periods of time, at different rates, and through different routes. Secondly, this study compares regions within the Netherlands. Agricultural statistics provide quantitative data on provincial or regional levels. Taken together with regional historical studies, these agricultural statistics on the provincial or regional levels bring to light variations in innovation. Because, as noted repeatedly, agricultural innovation is locationspecific, this regional comparison clarifies how and to what extent agricultural innovation differs locally.

Because this study uses different approaches, a wide range of data and sources has been consulted, using both quantitative and qualitative material. Quantitative data, to begin with, are compiled to measure the magnitude of innovation, to following long-term developments, to identify key turning-points, and to connect agricultural innovation to other long-term developments, such as population growth or rising living standards. Data on imports and exports have been compiled from the Dutch national trade statistics, the Statistiek van den In-, Uit, en Doorvoer. Other quantitative data have been taken from historical studies or have been 
compiled from agricultural statistics published annually by the government, the Verslagen van den Landbouw.

Qualitative material has been analysed to identify networks, to track the diffusion process of certain innovations, and to clarify how knowledge exchange functioned in practice, changed over time, and was shaped by farmers and other actors. Agricultural periodicals and journals, for instance, show how contemporaries thought and talked about agricultural innovation. Minutes, annual reports, and correspondence from research institutes, consultants, and farmer organizations (mainly cooperatives) reveal how these actors were involved in agricultural innovation and knowledge exchange. Archival records of the ministry of agriculture (or its predecessors) as well as the minutes of the national parliament (the Handelingen der Staten-Generaal) grant insight into the changing governmental policy.

\subsection{Thesis Outline}

This study is organized in two parts. After this introductory chapter, part I places Dutch agricultural innovation in its wider context. First, in chapter 2 Dutch agricultural innovation is studied within its international economic context. Using insights from New Economic Geography, this chapter finds that Dutch agriculture benefited greatly from its favourable location within Europe. Industrialization, economic growth, and, subsequently, higher living standards in many parts of Europe, but particularly in neighbouring Britain and Germany, increased the demand for higher-value products. This resulted in Dutch agricultural specialization accelerating swiftly: Dutch farmers increasingly shifted from grain production to the production of processed goods, fruits, and vegetables. The proximity to industrializing countries also caused the Dutch agricultural sector to have easy access to various inputs and innovations. Trade statistics reveal that the imports of artificial fertilizers, seeds, and other innovations increased massively since the late nineteenth century. The specialization in higher- 
value products, however, caused the system of importing knowledge and innovation from abroad to reach its limits. The Netherlands started generating its own innovation and gradually transformed into an exporter of knowledge and innovation.

While chapter 2 places Dutch agricultural in its international economic context, the following chapter puts focus on the national political context. Why is it that the Dutch state, having ignored the agricultural cause during most parts of the nineteenth century, heavily invested in agricultural education and $R \& D$ during the twentieth century? While Dutch farmers had for centuries used locally-available inputs and innovation, this farming system ran out of steam, chapter 3 argues, when globalization, international competition, and agricultural specialization caused many Dutch farmers to rely heavily on fertilizers, seeds, and animal feed imported from abroad. As a consequence of this changing nature of innovation, individual Dutch farmers now often lacked the necessary know-how and saw their positions with regard to their suppliers weakened. Together with various changes in the political sphere - most importantly the broadening of the franchise in the closing decades of the nineteenth century weakened liberalism - these market failures caused the Dutch government to step in and to actively stimulate agricultural innovation by funding agricultural education and by setting up agricultural experiment stations and an agricultural consultancy system.

After part I of this study has discussed the economic and political context, part II studies Dutch agricultural innovation at a more disaggregated level. Chapter 4 aims to explain why and how the Netherlands transformed from a small user of artificial fertilizers compared to other European countries at the end of the nineteenth century into the largest user of artificial fertilizers per hectare a few decades later. Although part of the answer lies in, among other things, land-labour ratios or the high level of agricultural specialization of Dutch farmers, the expansive growth in artificial fertilizer usage would have been unlikely without a smooth knowledge exchange. Shortly reviewing the different channels through which useful knowledge 
on artificial fertilizers could be diffused, this chapter assigns an important role to the Dutch agricultural consultancy system which, a quick international comparison reveals, was one of the most elaborate systems of its time. The case of Jakob Elema, agricultural consultant for the province of Drenthe from the 1890s to the 1930s, exemplifies how individual consultants could improve local knowledge networks, could professionalize the 'on the ground' knowledge exchange, and could personify (or were the gateway to) new ways of acquiring knowledge, be it through press, lectures, or formal education.

Although the Dutch agricultural consultancy system was certainly crucial in setting up knowledge networks, a weak spot in this system was that its knowledge exchange largely depended on the willingness of the individual farmer to participate. Chapter 5 articulates that knowledge exchange within agricultural cooperatives, also highly important networks, had a comparative advantage. Once part of a cooperative, individual farmers were more or less obliged to follow and participate in the production methods, the technology, and the knowledge exchange of the larger group to be which they now belonged. The sugar beet cooperatives studied in the chapter 5 balanced between the freedom of their individual members and the uniformity and quality of the cooperatives' products. The sugar beet cooperatives contributed to the innovation capacity of their members by distributing knowledge and giving access to inputs, particularly seeds, and by conducting agricultural $R \& D$ (even investing in their own research institute), especially after the import of German seeds was stopped by the First World War.

Dutch farmers grasped the opportunities granted by integrating European markets, particularly markets for higher-value goods, with the aid of a set of institutions, mostly agricultural cooperatives and publicly-funded research institutes. These forces culminated in Dutch greenhouse horticulture. Chapter 6 explains how the Dutch export of horticultural products, usually perishable goods that had to be transported from the Dutch countryside to the 
German and British urban consumer as quickly as possible, hinged on a network of cooperative auctions and on the proximity of the South Holland glass district to the port of Rotterdam. Moreover, the high geographical concentration of the Dutch greenhouse horticultural sector in South Holland resulted in a high density of experiment fields, study clubs, suppliers, and researchers, which culminated in a dense knowledge network. Together with the willingness of cooperative rural banks and state guarantee funds to invest in greenhouse horticulture, the combination of these factors explain why the Dutch greenhouse horticultural sector became the largest of its kind and became the world leader in greenhouse horticultural technology.

The seventh and last chapter brings this study to its conclusion, as it shortly recaps the main findings and connects this study to academic debates, particularly the two academic debates discussed above. Lastly, this concluding chapter discusses the shortcomings of this study and presents pathways for future research. 


\section{CHAPTER II}

\section{AGRICULTURAL INNOVATION IN ITS ECONOMIC CONTEXT:}

\section{INTERNATIONAL TRADE AND ECONOMIC GEOGRAPHY}

\subsection{Introduction}

This chapter places Dutch agricultural innovation in its wider international economic context. It describes the main economic drivers behind the development of Dutch agricultural innovation and the Dutch agricultural sector more generally. Despite its small size, the Netherlands is currently one of the main exporters of agricultural products worldwide. Whereas most of the world's largest agricultural exporters produce bulk commodities, the Netherlands exports highvalue products, such as livestock products, vegetables, and processed arable products, while simultaneously importing bulk commodities, raw materials, and inputs on a large scale. Dutch agriculture can remain competitive only by relying heavily on foreign markets - for its products as well as its inputs. ${ }^{1}$

Dutch agriculture has been heavily dependent on foreign markets since at least the sixteenth century. With early-modern Amsterdam as Europe's staple market for grains, Dutch farmers had easy access to bulk commodities from abroad and could thus specialize in highvalue products. Since the late nineteenth century this system - importing bulk commodities while exporting high-value products - expanded further, while Dutch agricultural exports also diversified and changed in character. Dutch trade statistics, the Statistiek van den In-, Uit-, en Doorvoer, reveal that since the 1880 s Dutch exports of various high-value arable and horticultural products increased rapidly, including a wide range of products processed by the food industry. At the start of the nineteenth century it had been mainly the livestock farmers in

\footnotetext{
${ }^{1}$ In 2017, the Netherlands was the second largest exporter of agricultural products worldwide, after the US. The Netherlands was also third in net agricultural export, after Brazil and Argentina. M.A. Dolman, G.D. Jukema, and P. Ramaekers, eds., De Nederlandse landbouwexport in 2018 in breder perspectief, Wageningen Economic Research Rapport 2019-001 (Wageningen: Wageningen Economic Research, 2019), 7.
} 
the coastal provinces and the arable farmers in the sea-clay regions in the southwest and the north that were strongly dependent on foreign markets. In the following century, however, virtually all sectors of Dutch agriculture and all regions within the Netherlands became heavily export-oriented. How is this to be explained?

This chapter shows that accelerating globalization, integrating markets, and improving infrastructure ensured that Dutch farmers could exploit their favourable location within Western Europe, close to urban consumers, particularly British and German ones, who demanded increasingly more and diverse high-value products. The proximity to industrializing countries also allowed Dutch farmers to profit from spill-over effects. Lacking anything close to a national agricultural innovation system or network, Dutch farmers innovated by using German artificial fertilizers, German seeds, and foreign machinery, often British or American.

This chapter also argues that this geography argument is not sufficient to understand the export-orientation of Dutch agriculture. The explanation also lies in the ability of the Dutch agricultural sector to react to certain challenges and to fully grasp the potential. The growth of agricultural export resulted in expanding production chains, a wide range of different actors supplying agricultural inputs, and a swift knowledge intensification. The importance of international trade made the Dutch agricultural sector one of the first worldwide to 'industrialize' its farming, as some agricultural historians coin the capital-intensive growth of agriculture during the twentieth century. By 'industrializing', the Dutch agricultural sector could sustain, or even expand, its position on foreign markets. The Dutch agricultural sector, in other words, became organized in such a way that it could fully utilize its favourably geographic position in Western Europe. A growing dependence on international markets had required Dutch farmers to innovate; the innovation applied by Dutch farmers further increased this international orientation. 
This chapter is organized as follows. The following section uses trade statistics to quantify Dutch agricultural export and to highlight the peculiar characteristics of this export, namely its diversity and the growing relative importance of processed goods. Section 2.3 explains this growth of Dutch agricultural export by pointing at urbanization, industrialization, and improving infrastructure. Section 2.4 discusses the changing trade in inputs and narrates how the Netherlands became less dependent on foreign inputs. In section 2.5 the two most important results of the expanding Dutch agricultural export are discussed. The last section concludes.

\subsection{The development of Dutch agricultural trade}

To get insight into Dutch agricultural trade one has to rely upon the national trade statistics, the Statistiek van den In-, Uit-, en Doorvoer (hereafter SIUD), which appeared since 1846. These trade statistics have some serious flaws. Besides the possibilities of errors by state officials or of fraud by traders, the statistics lack product differentiation, as news goods are often recorded as separate categories after a couple of years only. The (current) prices used to calculate the value of the traded goods barely change over time, which makes these prices unreliable. During the nineteenth century, for instance, nearly all prices are based on 1846 or 1871 unit-values, while fully ignoring price fluctuations between and after these years.

Despite these flaws, the Dutch trade statistics have been used by historians to quantify Dutch international trade. Dirk Pilat has compiled data on Dutch agricultural trade between 1846 and 1924, though only gathering data on exports, leaving out imports. ${ }^{2}$ By supplementing Pilat's dataset with data about imports, an overview can be created of the long-term development of Dutch agricultural trade. A couple of distinct changes are discernible.

\footnotetext{
2 Dirk Pilat, Dutch Agricultural Export Performance (1846-1926), Historia Agriculturae 19 (Groningen: Nederlands Agronomisch-Historisch Instituut, 1989).
} 
Combing the SIUD trade data with estimates of total Dutch agricultural production as presented by Merijn Knibbe reveals that from 1849 to the 1870 s the percentage of Dutch agricultural production that was exported fluctuated around $40 \%{ }^{3}$ This percentage is presumably lower-bound, as this total Dutch agricultural production includes a wide variety of fodder crops used to feed cattle herds or draft horses and never intended for (international) trade. After the percentage dropped in the 1870s and 1880s, possibly due to the Agrarian Depression, it increased during the 1890 s, peaking at around $50 \%$ during the early years of the First World War.

Graph 2.1. Export in current prices of horticulture, livestock, and arable products, 18461926 (in thousands of guilders).

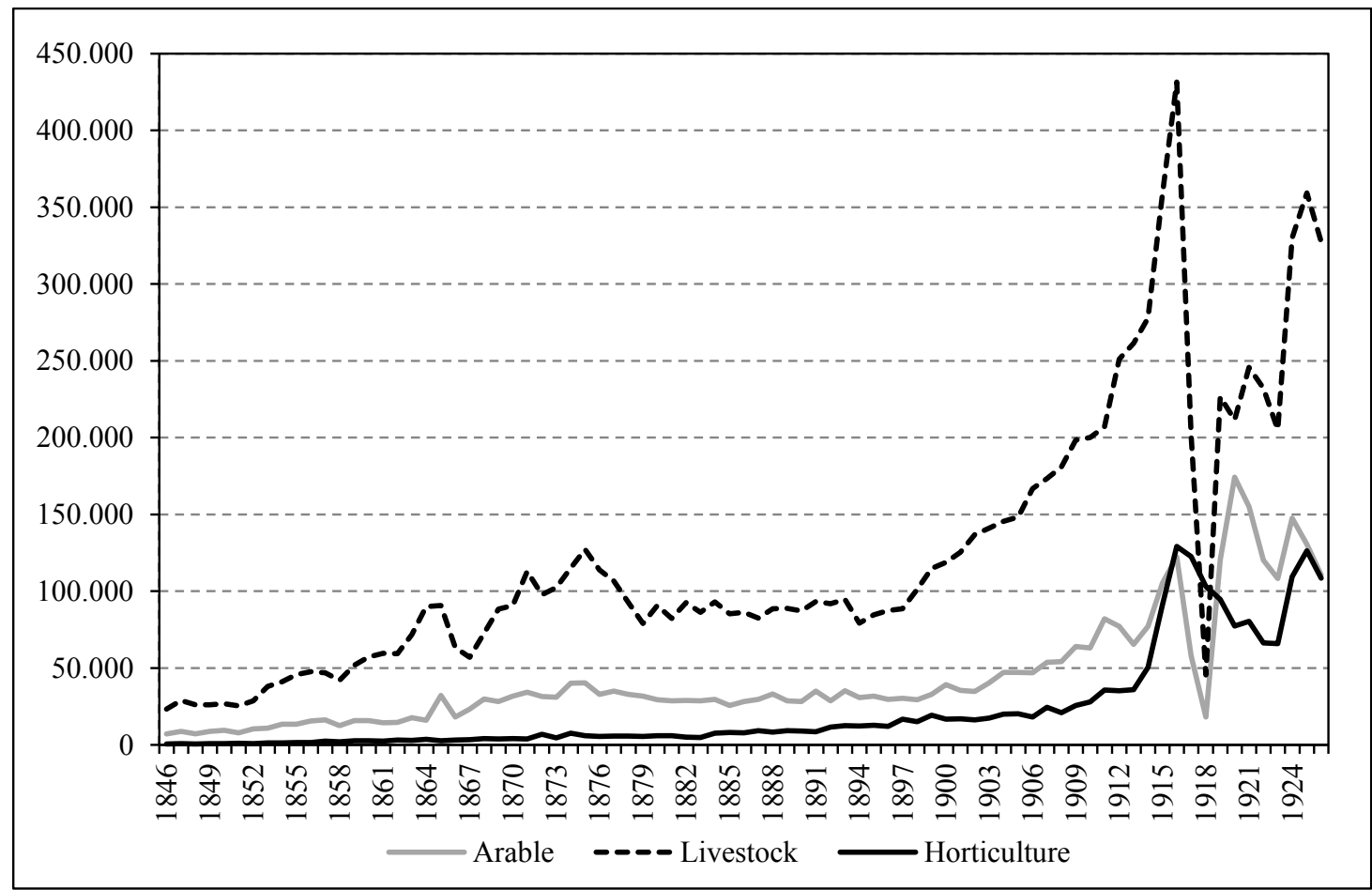

Source: Pilat, Dutch Agricultural Export Performance, 72-74.

\footnotetext{
${ }^{3}$ Merijn Knibbe, Agriculture in the Netherlands 1851-1950. Production and Institutional Change (Amsterdam: NEHA, 1993).
} 
When disentangling Dutch agricultural export between livestock products, arable products, and horticultural products, as Graph 2.1 does, it becomes clear that the value of exports of livestock products was much higher than the value of arable or horticultural products, not surprising when considering that the category of livestock products also includes living animals. The value of livestock exports increased almost continuously since the mid-nineteenth century, and at a strong pace especially since the late mid-1890s. The peak during the First World War is particularly striking, though understandable considering the general distortions of international trade due to the war circumstances.

Table 2.1 Index of Dutch agricultural export, 1846-1925 (1860=100)

\begin{tabular}{rrrrrr}
\hline Year & Arable & Livestock & Horticulture & Unprocessed & Processed \\
\hline 1846 & 51 & 54 & 26 & 47 & 57 \\
1850 & 83 & 64 & 38 & 65 & 69 \\
1855 & 90 & 86 & 55 & 87 & 84 \\
1860 & 100 & 100 & 100 & 100 & 100 \\
1865 & 229 & 139 & 87 & 202 & 121 \\
1870 & 215 & 138 & 130 & 180 & 133 \\
1875 & 239 & 157 & 141 & 208 & 149 \\
1880 & 209 & 123 & 186 & 153 & 138 \\
1885 & 254 & 146 & 291 & 174 & 178 \\
1890 & 316 & 146 & 386 & 199 & 181 \\
1895 & 389 & 153 & 486 & 177 & 235 \\
1900 & 426 & 206 & 681 & 189 & 332 \\
1905 & 499 & 219 & 817 & 232 & 347 \\
1910 & 620 & 262 & 1093 & 280 & 425 \\
1915 & 685 & 301 & 2051 & 319 & 539 \\
1920 & 601 & 147 & 1136 & 213 & 287 \\
1925 & 776 & 363 & 2041 & 395 & 601 \\
\hline Source: Pilat, Dutch Agricultural Export Performance, 68-71, $77-78$ &
\end{tabular}

The most significant growth in Dutch agricultural export occurred after the 1880s. Arable export more than tripled between 1880 and 1915, while horticultural export even increased tenfold in this period. The growth in export of processed products, which also includes processed livestock products (particularly dairy products) stagnated somewhat after the $1860 \mathrm{~s}$, to increase 
four-fold between 1880 and 1915. Export per capita almost doubled between 1880 and 1915. Although these per capita figures are based on the entire Dutch population, it can be safely assumed that these figures would be roughly the same when focusing only on the Dutch farming population - the share of Dutch labour force active in farming did not drop significantly during this period. This implies that, overall, Dutch farmers started exporting about twice as much.

Disentangling the growth in arable export and horticultural export confirms that the 1880 s were a turning point. The growth in horticultural export, as depicted in Graph 2.2, can be fully attributed to a growth in vegetable exports. Between the 1880s and the First World War the export in vegetables increased five-fold, while the export in fruits, bulbs, and hedges was insignificant, at least compared to the exports of vegetables.

Graph 2.2. Exports of vegetables, fruits, bulbs, and hedges, 1846-1926 (in tons).

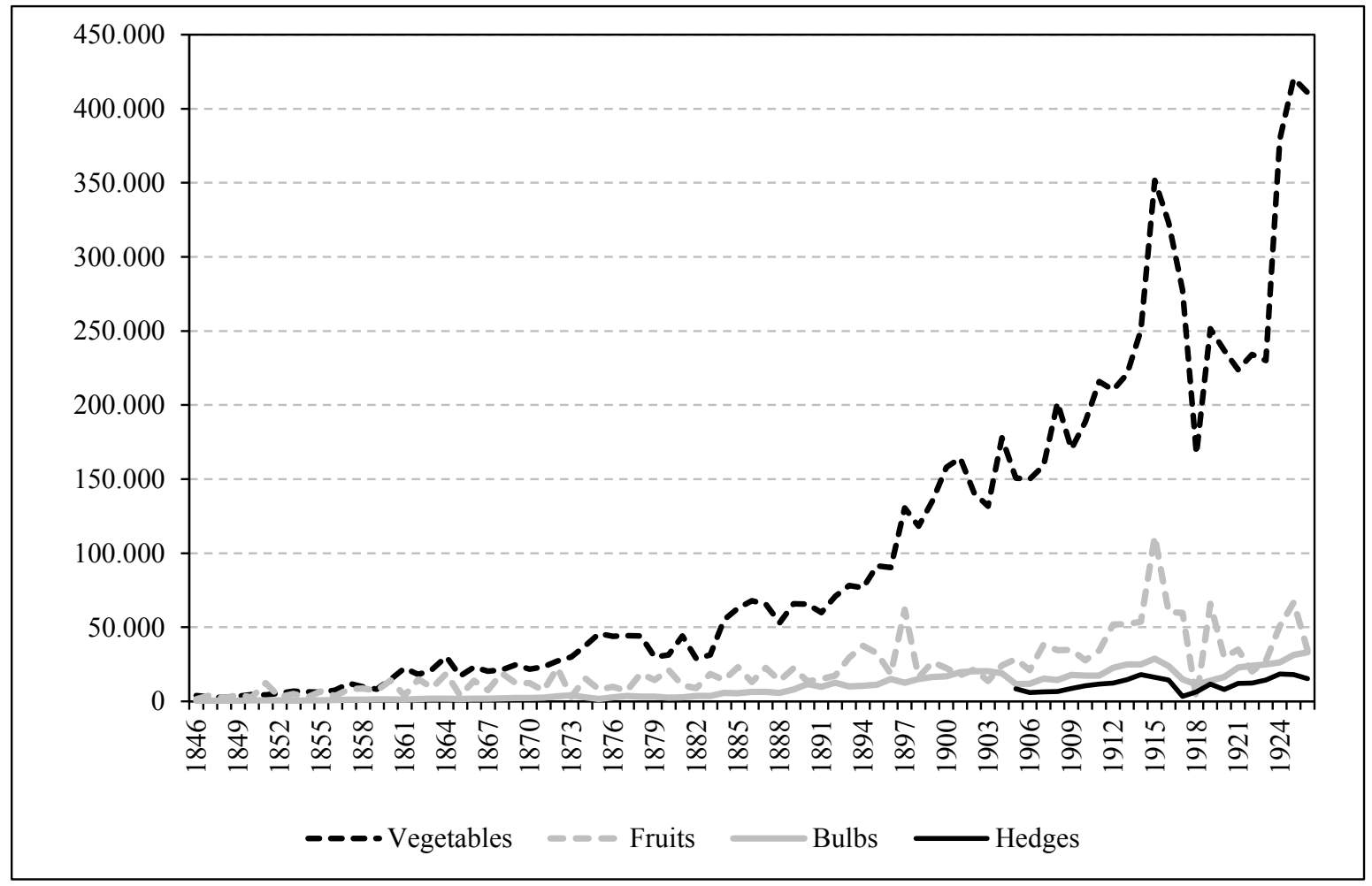

Source: SIUD, 1846-1926. 
Among the arable products, potatoes and sugar beets were the most exported. Graph 2.3. shows the export quantities of the five main unprocessed arable crops. Note that these five crops only represent part of the total unprocessed arable export, as arable export was highly diversified. Until the 1860 s the export of potatoes and sugar beets was not significantly higher than the exports of the other main arable crops. Since then, however, the exports of sugar beets started increasing, which might be attributed to the growing sugar industry in Belgium (see Chapter 5). In the 1880s also the exports of potatoes started to rise, with large growth rates especially in the 1900s. The more than threefold-increase of potato and sugar beet exports between the $1860 \mathrm{~s}$ and the First World War summarizes the link between agricultural export and knowledge intensification: as potatoes and sugar beets require much more fertilizing and treatment than grains, the growing exports of these two root crops lead to a more intensive fertilizing and, ultimately, to a large usage of artificial fertilizers. Belgian economic historian Jan Blomme has shown that in those Belgian regions with a large share of what he calls 'industrial crops' (vegetables, potatoes, sugar beets) the artificial fertilizer usage per hectare was significantly higher than regions with a large share of grain cultivation. ${ }^{4}$

\footnotetext{
${ }^{4}$ Jan Blomme, The Economic Development of Belgian Agriculture 1880-1980. A Quantitative and Qualitative Analysis, Studies in Belgian Economic History 3 (Brussel, 1992), 248.
} 
Graph 2.3. Exports of potatoes, sugar beets, grains, flax, and seeds, 1846-1926 (in tons).

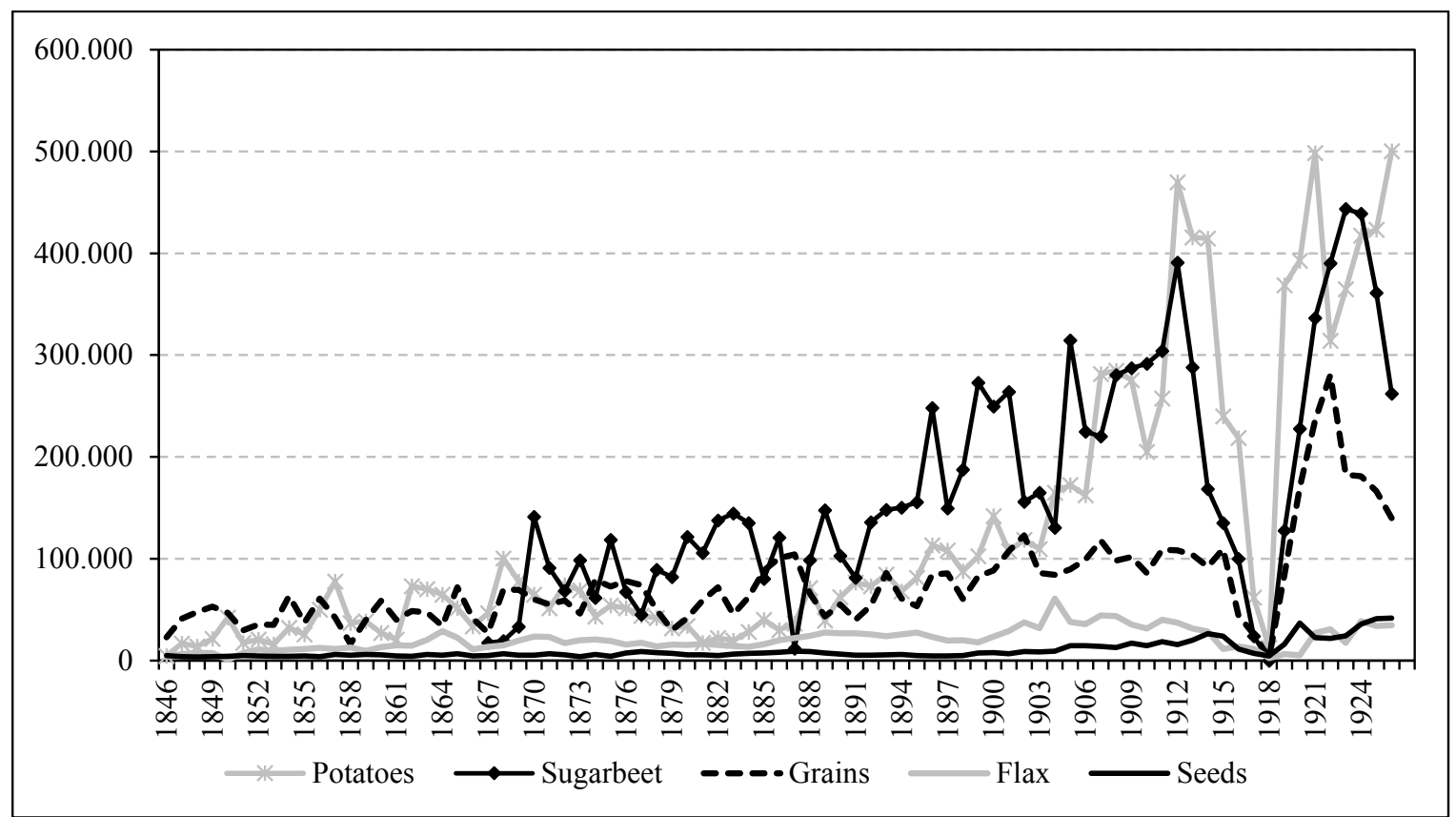

Source: SIUD, 1846-1926.

While potatoes and sugar beets explain the rapid rise in the export of unprocessed arable products, these rootcrops also tell the story of increased processed exports. Graph 2.4 shows the quantities of the four main processed arable products, namely potato starch, beet sugar, bran, and processed wheat. Whereas the exports of unprocessed potatoes and sugar beets had boomed after the 1880 s, comparable developments are discernible with the export of potato starch and beet sugar. Potato starch exports increased at a steady high rate since the $1870 \mathrm{~s}$. Beet sugar exports grew rapidly in the 1900s and 1910s, possibly due to the establishment of seven sugar beet cooperatives (see Chapter 5). During and after the First World War beet sugar exports diminished, because the international sugar market became organized through international trade agreements and because the Dutch central government set a maximum to sugar beet cultivation to stimulate grain production in order to secure domestic food provision. The export of potato starch, though, recovered to pre-war levels swiftly after the First World War. It epitomizes the large influence of the processing industry on Dutch arable farming. 
Graph 2.4. Exports of potato starch, beet sugar, bran, and wheat, 1846-1926 (in tons)

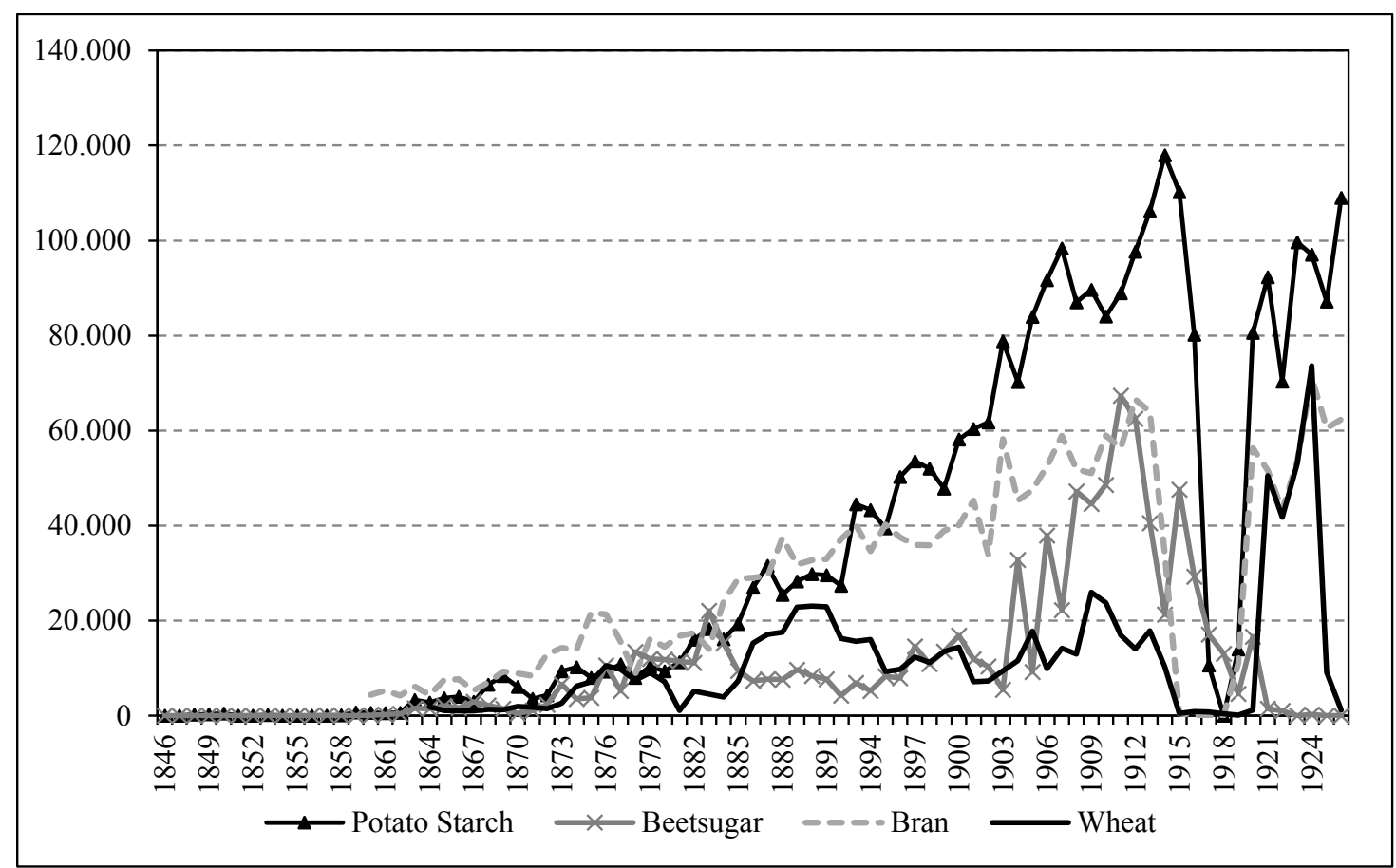

Source: SIUD, 1846-1926.

The figures above clearly reveal the following characteristics of Dutch arable export (including horticultural products). Since the 1880s Dutch arable export rapidly increased in volume. This was largely due, though certainly not confined, to the growth in high-value products such as vegetables, potatoes, and sugar beets. This growth in volume also coincided with the expansion of the Dutch processing industry, which is most clearly illustrated in the growing exports of potato starch, bran, beet sugar, and processed wheat since the $1880 \mathrm{~s}$. The following section presents explanations for this export growth since the 1880s.

\subsection{Explaining the growth of Dutch agricultural export}

The growth of Dutch agricultural export since the 1880s was driven by three developments. First of all, population growth and urbanization led to an increasing food demand. Second, industrialization resulted in higher living standards and in an outflow of labour from agriculture to industry. Because the agricultural sectors of Britain and Germany, shrinking in relative terms, 
were unable to feed their expanding industrial sectors, Dutch farmers eagerly met the increasing British and German demand for higher-value products. This would not have been possible, or would have developed less swiftly, without improving infrastructure. Railways, waterways, and steam-powered shipping connected remotely-located agricultural areas to international markets while also reducing travel time, important particularly for perishable goods.

Even though these three developments accelerated especially after circa 1870 , they surely had an impact on Dutch agriculture well before. Population growth and urbanization rates in the North Sea area had been comparatively high since at least the Middle Ages and had stimulated agricultural specialization and the development of markets. ${ }^{5}$ By the end of the Middle Ages, land pressure in the pasture regions (Holland, Friesland, and parts of Utrecht), had led to a shift from arable farming to animal husbandry: farmers sold their meat, living animals, and dairy products to urban citizens in Holland and Flanders. ${ }^{6}$ The sea-clay regions of Zeeland and Groningen, by contrast, developed in the opposite direction, specializing in arable production by delivering grains and raw materials for proto-industrialization to cities throughout the Low Countries. Although farming in the less fertile inland provinces of the Netherlands was less specialized, various studies convincingly argue that agriculture in these parts was certainly not as stagnant as older historical literature has suggested. Farmers in the

\footnotetext{
${ }^{5}$ The province of Holland had annual growth rates of $0.83 \%$ between 1514 and 1622 and of $0.5 \%$ between 1622 and 1680 - high numbers when considering that the population of many European regions experienced stagnation or decline. Holland had also reached an astonishing high urbanization degree of $54 \%$ by the sixteenth century. Although urbanization rates were lower in other parts of the Low Countries -28 to $31 \%$ in Brabant, 21 to $25 \%$ in Friesland, and less than $20 \%$ in the inland provinces - they were still higher than the 10 to $15 \%$ in most parts of Europe at the time. Figures originally from Jan De Vries, European Urbanization 1500-1800 (Cambridge, MA: Harvard University Press, 1984)., but quoted from J. Bieleman, Boeren in Nederland. Geschiedenis van de landbouw 1500-2000 (Amsterdam: Boom, 2008), 45. For a review of Dutch population growth and urbanization and its correlation with economic growth, see Jan De Vries and Ad van der Woude, The First Modern Economy: Success, Failure, and Perseverance of the Dutch Economy, 1500-1815 (Cambridge: Cambridge University Press, 1997), 57-80. Annual population growth rates come from D.B. Grigg, Population Growth and Agrarian Change. An Historical Perspective, Cambridge Geographical Studies 13 (Cambridge: Cambridge University Press, 1980), $147-48$.

${ }^{6}$ These developments were also partly driven by ecological conditions, such as soil sinking due to peat extraction.
} 
inland provinces specialized in tobacco production or earned extra cash by selling pork or beef at local markets. Here, too, farmers reacted to market changes. ${ }^{7}$

Dutch farming was strongly affected by population growth elsewhere in Europe, particularly in Britain. The British population increased from 5 million in 1700 to 30 million in 1900. British urbanization rates increased from around $25 \%$ in the mid-eighteenth century to more than $75 \%$ around 1900 . This growing urban population relied heavily on food imports. Shortly before the First World War, Britain imported $72 \%$ of its dairy products, $40 \%$ of its meat, and $79 \%$ of the flour required for human nutrition. ${ }^{8}$ Dutch farmers profited greatly from this British food demand, especially after the British Corn Laws, protecting British grain production, were appealed in 1846. Dutch contemporaries described the British food market as 'a bottomless pit which can never be filled'.

While experiencing unprecedented population growth, Britain was also the most wealthy nation of its day, resulted in a growing demand for high-value products - a demand Dutch farmers were happy to meet. Pilat calculated that Dutch cheese exports increased with $130 \%$ between 1846 and 1865, Dutch butter exports with 175\%, and Dutch bovine cattle exports even twenty-fold. Also the exports of Dutch horticultural products, likewise regarded as typically high-value products, boomed. From 1846 to 1926, Pilat estimated, vegetables and fruits as share of total Dutch agricultural export grew from $2 \%$ to $17 \% .{ }^{10}$ Although these figures cannot be explained by developments in Britain alone - most of Western Europe experienced

\footnotetext{
${ }^{7}$ The notion that the inland provinces were in no way stagnant is most vigorously voiced in J. Bieleman, Boeren op het Drentse zand, 1600-1910. Een nieuwe visie op de "oude” landbouw, AAG Bijdragen 29 (Wageningen, 1987). and J.L. van Zanden, De economische ontwikkeling van de Nederlandse landbouw in de negentiende eeuw, 1800-1914, AAG Bijdragen 25 (Wageningen, 1985). For Dutch tobacco production, see H.K. Roessingh, "Tobacco Growing in Holland in the Seventeenth and Eighteenth Centuries: A Case Study of the Innovative Spirit of Dutch Peasants," The Low Countries History Yearbook: Acta Historiae Neerlandicae, no. 11 (1978).

${ }^{8}$ All figures in this paragraph (which exclude Scotland) come from Grigg, Population Growth and Agrarian Change. An Historical Perspective, 163-69.

${ }^{9}$ J. Bieleman, Five Centuries of Farming. A Short History of Dutch Agriculture 1500-2000, Mansholt Publication Series 8 (Wageningen: Wageningen Academic Publishers, 2010), 153.

${ }^{10}$ Bieleman, Boeren in Nederland. Geschiedenis van de landbouw 1500-2000, 275.
} 
economic growth in this era - it was the seemingly insatiable British market particularly that brought Dutch agriculture prosperity. ${ }^{11}$

The period of progress experienced due to the exposure to the British market came to a sudden halt in the 1870s. Integrating markets and falling transportation costs, once to the benefit of Dutch farmers, now worked against them. Large imports of agricultural products from overseas and from Eastern Europe caused the European food market to collapse. Various historians have argued that Dutch agriculture, being highly export-oriented, was hit severely. Others, however, warn not to overestimate the effects of this Agrarian Depression. Knibbe argues that price declines were problematic particularly for Dutch grain producers, but less so for Dutch livestock farmers, who might have profited from lower prices for animal feed. ${ }^{12}$ Pilat points out that the effects of the Agrarian Depression were mitigated by an increasing urban food demand and rising living standards domestically. ${ }^{13}$ With the Dutch home market increasing in size, Pilat argues, Dutch farmers (re)gained previously lost market shares. ${ }^{14}$ Jan Luiten van Zanden, lastly, nuances the view that the Agrarian Depression was the starting-point for the specialization and diversification of Dutch agriculture. The shift towards high-value products, he convincingly argues, started before prices dropped. Indeed, the growth in horticultural export continued throughout the Agrarian Depression, while the decline in processed export was much smaller relative to the vast decline in unprocessed export (see Table 2.1). The Agrarian Depression might have accelerated the transformation of Dutch agriculture. It was not, however, its prime cause. ${ }^{15}$

\footnotetext{
${ }^{11}$ J.L. van Zanden and Arthur van Riel, The Strictures of Inheritance: The Dutch Economy in the Nineteenth Century, trans. Ian Cressie (Princeton, NJ: Princeton University Press, 2004), 201.

${ }^{12}$ Knibbe, Agriculture in the Netherlands 1851-1950. Production and Institutional Change, 138.

${ }^{13}$ Between 1870/72 and 1880/82, as household accounts reveal, expenditure on bread and potatoes dropped from $31.6 \%$ of the total household budget to $20.6 \%$. Relative expenditure on higher-value products (dairy, fish, meat, vegetables, fruits, etc.), by contrast, increased from $24 \%$ to $36.1 \%$. For these as well as the population and urbanization figures, see Van Zanden and Van Riel, The Strictures of Inheritance: The Dutch Economy in the Nineteenth Century, 274-78.

${ }^{14}$ Pilat, Dutch Agricultural Export Performance (1846-1926), 29.

${ }^{15}$ Van Zanden, De economische ontwikkeling van de Nederlandse landbouw in de negentiende eeuw, 1800-1914.
} 
Foreign markets, particularly those in Britain and Germany, became better accessible through improvements in infrastructure. Prior to the nineteenth century basically all freight transport in and to the Netherlands went through waterways. The Netherlands had inherited a network of waterways which, though one of the best transport systems during the early modern centuries, was ill-suited for the nineteenth-century Transport Revolution. Most Dutch ports were not easily accessible for large seagoing vessels and the inland waterways to Germany were often too shallow and too narrow for large cargo. Moreover, the Dutch waterway network, concentrated in the coastal provinces, did not penetrate deep into the inland provinces. ${ }^{16}$

After early nineteenth-century attempts to resolve these issues had largely failed, more success was achieved since the 1860s. Estimates of capital formation show peaks in investments in waterways between 1860 and 1880 and again in the 1920s and 1930s: new canals connected remotely-located industrial regions (particularly peat-extracting areas or textile-producing towns) to the national waterway network, while also the main Dutch ports were made better accessible for seagoing vessels and the navigability of the rivers that reached the German hinterland was improved. ${ }^{17}$ As a result, cargo transported through inland waterways grew fifteen-fold between 1830 and 1913, while the transport to Germany through the Rhine increased from 0.4 million tonnes in 1868 to 19.6 million tonnes in 1913. Most of this transport went through the port of Rotterdam, which became the main port of continental Europe after 1880 as a result of its close location to Britain and the rapid industrialization of the Ruhr area. Technological improvements in steam shipping reduced travel time and costs to Britain's main ports - freight rates between Rotterdam and England dropped with $75 \%$ between 1870 and

\footnotetext{
${ }^{16}$ Ruud Filarski and Gijs Mom, Van transport naar mobiliteit. De transportrevolutie, 1800-1900 (Zutphen: Walburg Pers, 2008), 53.

${ }^{17}$ Peter Groote, "Kapitaalvorming in infrastructuur in Nederland 1800-1913" (Rijksuniversiteit Groningen, 1995), 150-51, 169-71. Ewout Frankema, "Kapitaalvorming in infrastructuur in Nederland 1900-1970" (Rijksuniversiteit Groningen, 2001), 87.
} 
1913. ${ }^{18}$ With the Transport Revolution, in short, the Netherlands accomplished its potential as the transport hub of Western Europe.

Apart from the waterway network and Rotterdam's port, a third pillar of Dutch infrastructure was its railway network. Despite the fact that the Dutch railway network had been connected to the German railway network since 1856, it could not compete with waterway transportation: the railway share in cargo transport to Germany dropped from $30 \%$ in 1880 to $9 \%$ in 1910 . However, railways were pivotal particularly in improving transportation on the local level. Since the late 1870s an expanding system of tramways, smaller and cheaper than railways, connected once remotely-located regions to national ports, waterways, or railways, which was important especially for agricultural areas where waterways had been lacking or where the slowness of waterway transportation was problematic for the trade in perishable goods. A local tramway company in the southeast of the Netherlands, for example, specialized in the transportation of sugar beets, which had to be transported swiftly to not lose sugar content: half of the 200,000 tons of cargo transported by this company in 1910 comprised of sugar beets. ${ }^{19}$ In Groningen, tramway lines had stops at strawboard factories and sugar beet factories to connect these to their suppliers: one local tramway company transported 8,672 tons of straw in 1893 , nearly $40 \%$ of its entire transported cargo that year. ${ }^{20}$

Estimates of capital formation show that the Dutch tramway system experienced its peak between 1900 and 1930, after which the expansion of paved roads and the introduction of truck transport caused severe competition. Total kilometres of paved roads had barely increased in the nineteenth century, but new investments in paved roads, with peaks in the late 1920s, late 1930 s, early 1940 s and persisting growth since the 1950s, resulted in an increase from 16,000 kilometres of paved roads in 1913 to 50,000 kilometres in the early 1970s. Paved roads and the

\footnotetext{
${ }^{18}$ Filarski and Mom, Van transport naar mobiliteit. De transportrevolutie, 1800-1900, 274-77, and 321-25.

${ }^{19}$ Filarski and Mom, Van transport naar mobiliteit. De transportrevolutie, 1800-1900, 245 and 356.

20 Marcel Clement, Transport en economische ontwikkeling. Analyse van de modernisering van het transportsysteem in de provincie Groningen (1800-1914) (Groningen: Wolters, 1994), 118-19.
} 
tramway system functioned simultaneously until the Second World War, after which the tramways were swiftly dismantled and local transportation was instead done with trucks. ${ }^{21}$

Improvements in Dutch infrastructure, to sum up, affected Dutch agriculture in two ways. First, improvements on the local level connected arable farmers to traders, suppliers, and the food industry. Paved roads, tramways, and local canals ensured that that their products could be transported to, say, the local market or the local potato starch factory more easily. Second, the important position of Rotterdam's port within Western Europe and the increased navigability of the main waterways to the German hinterland resulted in a less costly, more swiftly, and larger international trade, ultimately making the Netherlands the main transit centre for Western Europe and for industrializing Germany in particular. Within this integrating international transportation system, Dutch farmers could fully profit from, as one Dutch historian put it, the favourable location of the Netherlands 'between Reich and Empire'. ${ }^{22}$

\subsection{Benefitting from 'geography of innovation'}

The improving Dutch infrastructure and the role of the Netherlands as transit centre of Western Europe decreased the relative distance, in terms of travel costs and travel time, between Dutch farmers and their consumers. It also had effect on the supply of inputs, innovation, and knowledge. Economists associated with New Economic Geography, shortly discussed in the introduction to this study, make the strong case that spatial distribution of economic activity is attributable to proximity to markets, rather than, as other prominent economic theories argue, to factor endowments. Firms, simply put, tend to locate close to their customers and their suppliers. Economic geographers also identify such a spatial dimension to innovation.

\footnotetext{
${ }^{21}$ Gijs Mom and Ruud Filarski, Van transport naar mobiliteit. De mobiliteitsexplosie, 1895-2005 (Zutphen: Walburg Pers, 2008), 51-53. Frankema, "Kapitaalvorming in infrastructuur in Nederland 1900-1970," 40-45, 5864. Groote, "Kapitaalvorming in infrastructuur in Nederland 1800-1913," 89, 129.

${ }^{22}$ H.A.M. Klemann, "Tussen Reich en Empire. De economische betrekkingen van Nederland met zijn belangrijkste handelspartners. Duitsland, Groot Brittannië en België en de Nederlandse handelspolitiek, 19291936" (Erasmus University Rotterdam, 1990).
} 
Innovation, they argue, benefits from geographic clustering. Firms tend to be more innovative when closely located to innovative activity: agglomeration promotes spill-overs. Proximity to the source of innovation, or the decline of the relative distance through improved infrastructure, reduces costs and risks and makes it easier to build on existing innovation. Proximity, in short, improves innovativeness. ${ }^{23}$

Although this theory of 'geography of innovation', as it is called, is based on large modern-day firms and was not created with early twentieth-century farmers in mind, it still presents useful insights. Dutch farmers, too, profited from their proximity to innovative activity. Without large-scale mechanization, most Dutch farmers increased their productivity by applying artificial fertilizers on a large scale, as discussed in more detail in Chapter 4. Lacking a strong chemical industry or fertilizer producers, Dutch agriculture was strongly dependent on the influx of artificial fertilizers from Latin America or from Germany, the global chemical leader at the time. Well-developed infrastructural links to the Ruhr area lowered prices and ensured that the suppliers of artificial fertilizers, be it private traders or supply cooperatives, had relatively easy contacts with German companies, with few intermediaries increasing the price or further complicating the knowledge exchange between producers, suppliers, and farmers.

Graph 2.5 below presents 5-year averages of the Dutch imports of salpeter, phosphates, potassium fertilizers, and nitrogen fertilizers, while also presenting the Dutch exports of phosphates and nitrogen fertilizers. Exports of salpeter and potassium have been omitted, as they were barely noticeable due to their small size relative to the exports of phosphates and

\footnotetext{
23 'Innovation is more the product of group efforts than the result of solitary genius. An area with innovative activity will develop a set of specialized resources which provide comparative advantage for the next round of innovation.' Maryann P. Feldman, “Why Location Matters for Innovative Activity," in The Geography of Innovation, Economics of Science, Technology and Innovation 2 (Dordrecht: Kluwer Academic Publishers, 1994), 23. This paragraph also builds on Maryann P. Feldman and Nadine Massard, "Location, Location, Location: Institutions and Systems in the Geography of Innovation," in Institutions and Systems in the Geography of Innovation, Economics of Science, Technology and Innovation 25 (Dordrecht: Kluwer Academic Publishers, 2002), 1-20.
} 
nitrogen fertilizers. Graph 2.5 shows that besides a sharp decline during the First World War, the imports of artificial fertilizers overall increased. In fact, imports of phosphates and nitrogen fertilizers grew tenfold between the First World War and 1930, while exports merely doubled.

Graph 2.5 Imports and exports of salpeter, phosphates, potassium fertilizers, and nitrogen fertilizers, 1905-1940 (in tons and 5-year averages)

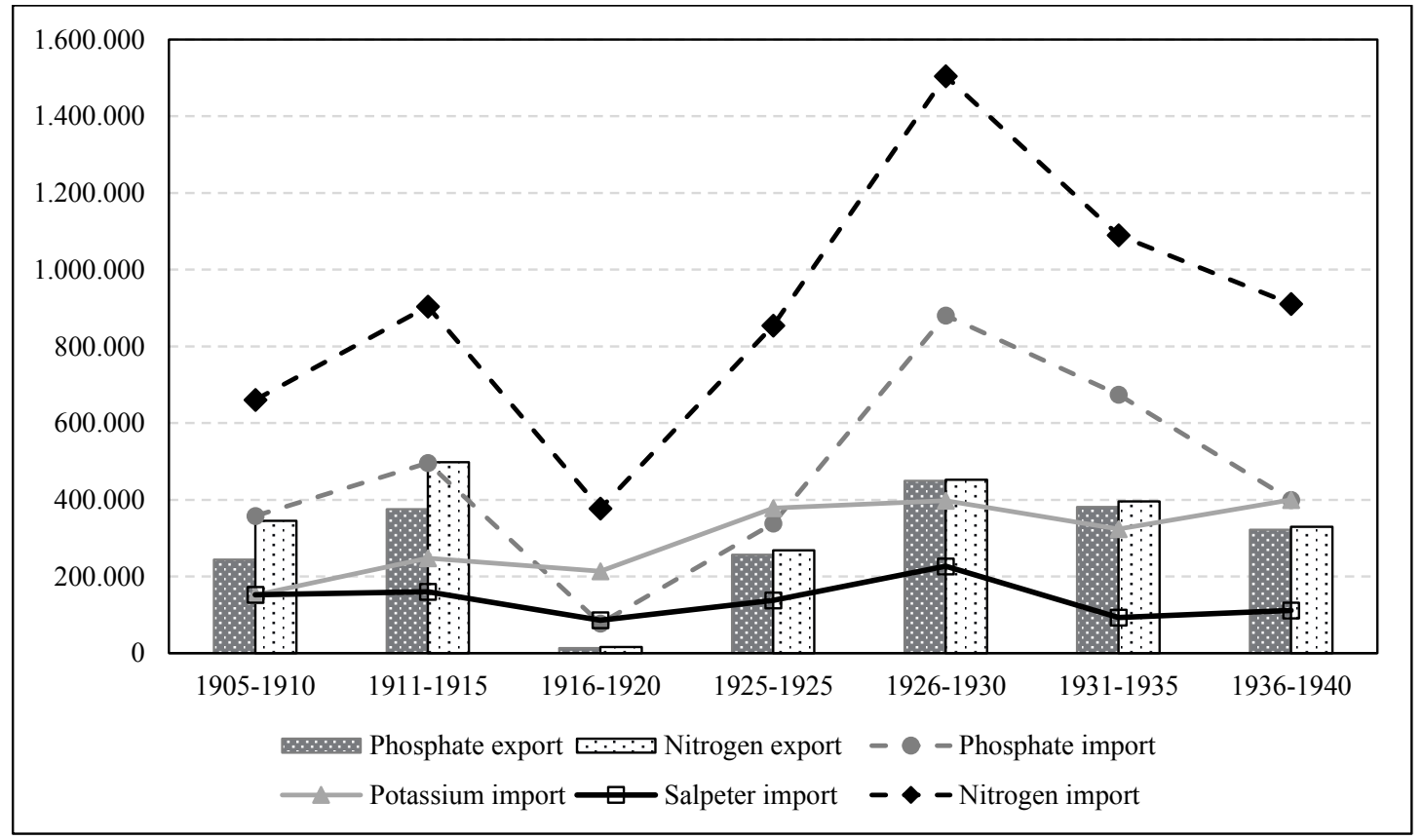

Source: SIUD, 1905-1940.

Graph 2.6 depicts the trade in beet seeds (which could include seeds for sugar beets as well as fodder beets). Until the 1920s, Graph 2.6 shows, the Netherlands was a net importer of beet seeds. Prior to the First World War it even imported almost twice as much beet seeds as it exported. As had been the case with artificial fertilizers, the First World War greatly hindered the imports of beet seeds, which caused production problems for the Dutch sugar beet industry (discussed in Chapter 5). Dutch seed companies thus started breeding their own beet varieties, to such an extent that the Netherlands became a net exporter of beet seeds, even exporting twice what it imported since the 1930s. 
Graph 2.6 Imports and exports of beet seeds and vegetable and flower seeds, 1906-1940 (in tons and 5-year averages)

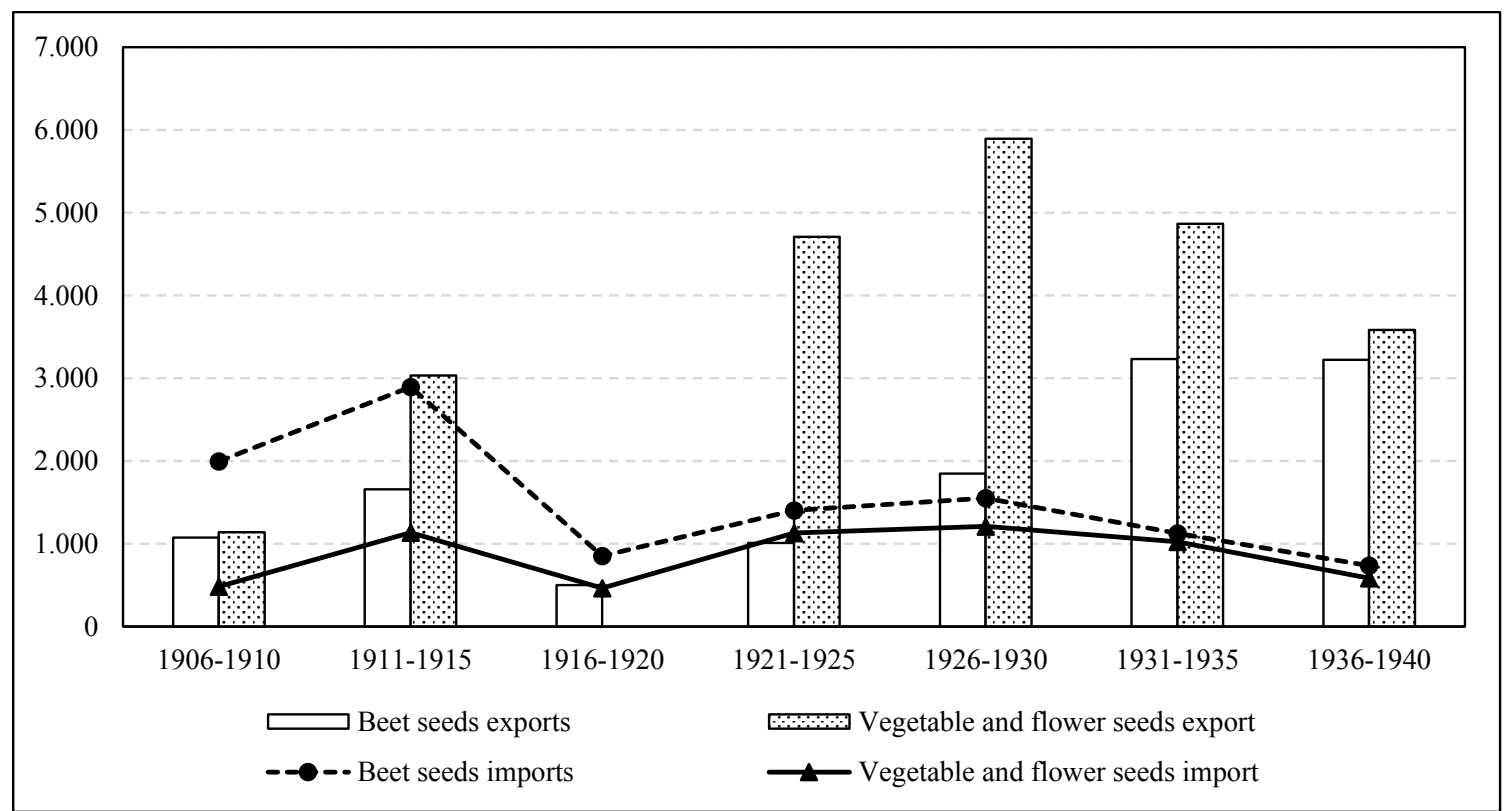

Source: SIUD, 1906-1940

Graph 2.6 also includes the trade in vegetable and flower seeds, which are combined one single category in the trade statistics. The development of trade in vegetable and flower seeds is exemplary for the transformation Dutch agriculture experienced since the late nineteenth century. As the breeding of vegetable and flower seeds is costly and labour-intensive, this is a clear example of a switch to high value products. The increase in the exports of vegetable and flower seeds - from 1,000 tons in the early 1910 s to 3,500 tons in the late 1930 s, with a peak of 6,000 tons in the late $1920 \mathrm{~s}$ - and the simultaneous drop in the imports of vegetable and flower seeds epitomizes the development of the Dutch seed industry, which is currently worldleading but has its early origins, at least when focussing on trade statistics, in the 1920s.

The development of the Dutch seed industry is perhaps better illustrated in the trade of seed potatoes. The Dutch trade statistics start categorizing seed potatoes as separate from regular potatoes in 1917. Graph 2.7 reveals that the export of seed potatoes increased with large growth rates in the latter half of the 1920s, when the export grew no less than ten-fold in five 
years (note the logarithmic scale of Graph 2.7). In the 1930s seed potato exports stabilized at around 100,000 tons yearly, while the imports simultaneously decreased about tenfold (apart from sudden peaks in 1938 and 1939). This means that the Dutch seed potato industry expanded throughout the 1920s and 1930s: it served international markets while also gaining a stronger foothold in the growing domestic market, which relied less and less on imports.

Graph 2.7, Imports and exports of seed potatoes in tons, 1917-1940 (log. scale).

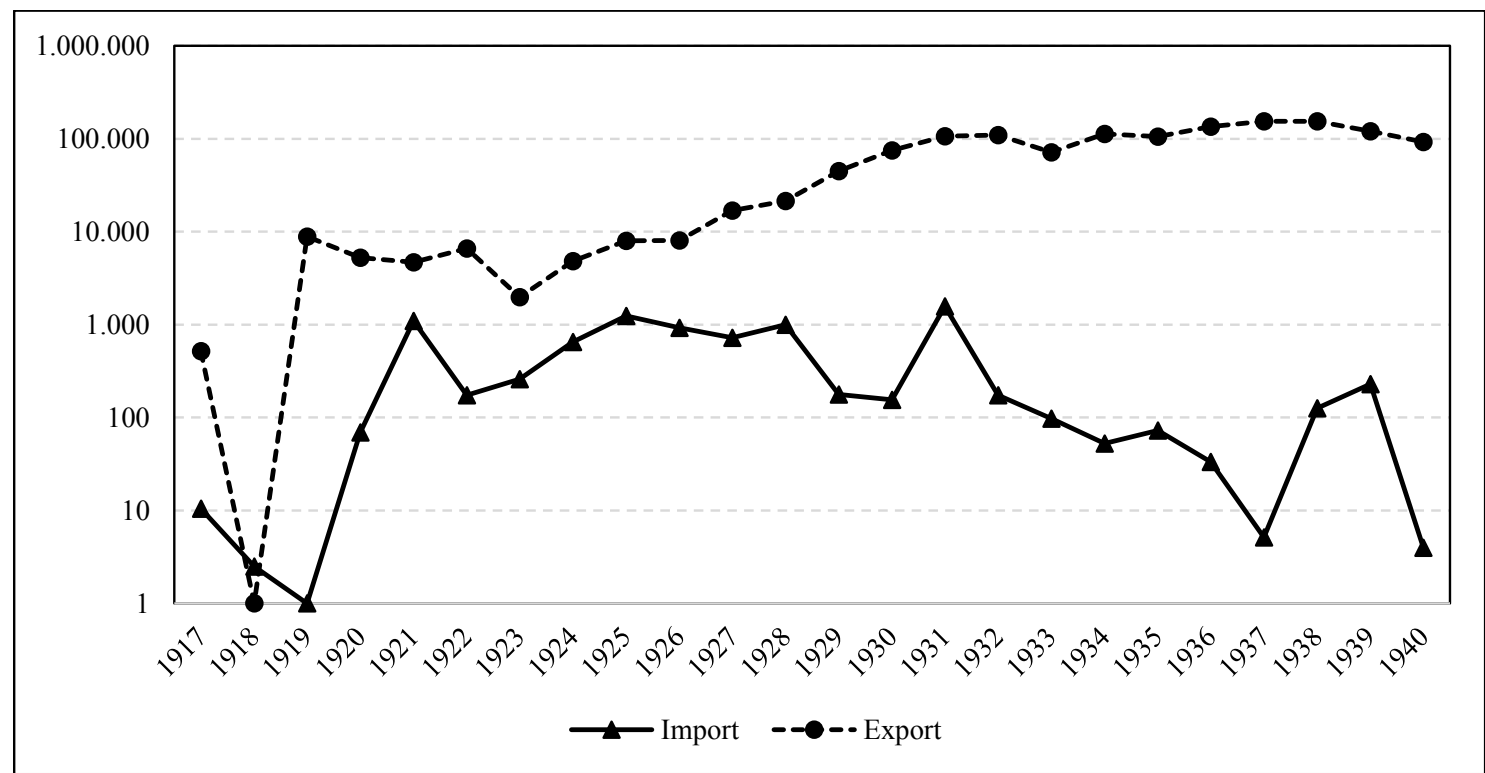

Source: SIUD, 1917-1940.

Note: The export values in 1918 and the import values in 1919 were below 1 ton.

Two main developments can be discerned from the figures discussed above. First, Dutch arable farming gained from innovative activity in the surrounding countries. Lacking heavy industry itself, the Netherlands had to rely on the chemical industry of surrounding countries for its artificial fertilizers, while also many of the seeds came from abroad. Without anything close to a counterfactual, one can only speculate how Dutch arable farmers would have performed without their location close to excellent infrastructure and the port of Rotterdam and without industrializing countries nearby. Second, since the 1920s particularly, but earlier or later for some subsectors, the Dutch agricultural sector aimed at reducing the dependency on imported 
inputs. The following chapters of this thesis will confirm that the food industry, cooperatives, and the government increasingly invested in agricultural R\&D. While innovation for Dutch agriculture had for long consisted of taking full advantage of spill-over effects - or, to put it bluntly, copying from neighbouring countries - the Netherlands increasingly generated knowledge and innovation by itself.

\subsection{The shift to 'externally-produced innovation'}

The relative importance of exports and imported inputs had (at least) two long-lasting effects. First, the relationship between farmers and their suppliers and customers changed drastically. Farmers had once produced their inputs themselves and been in direct contact with their customers, who could be local consumers as well as traders at the local market. The usage of imported inputs, the growth of long-distance trade, and the growing relative importance of the food industry changed this situation completely. Farmers became dependent on a variety of agents and became components of a much larger production chain.

Figure 2.1 contains a stylized depiction of this changing production chain. On the left is the production chain as it was before the rapid changes of the late nineteenth century. This is, admittedly, a great simplification, but it makes clear that within this production chain an individual farmer was barely dependent on other agents. After the late nineteenth century, however, seeds, fertilizers, and credit came to them through supply cooperatives, cooperative banks, traders, or from the food industry. The farmers no longer sold directly to the consumer, but traded with (several) retailers or other middlemen, while products that had to be processed before being marketed had to be delivered to the food industry, often through an agent. 
Figure 2.1. Simplified depiction of changing production chains

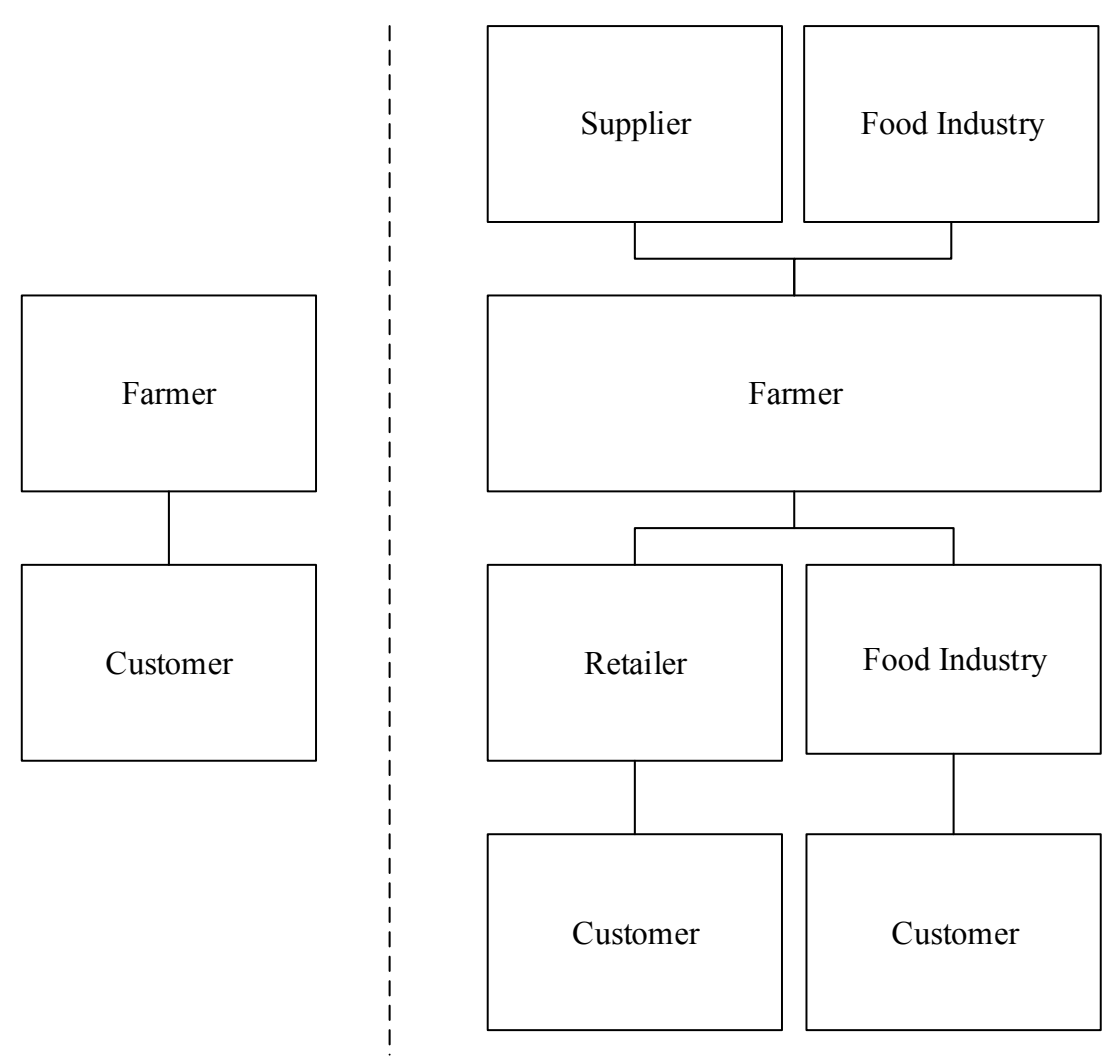

The changing production chains complicated matters for the individual farmer, who lost part of his freedom. His products, his production methods, and his innovation had to be in line with the larger production chain. Farmers became more dependent on their retailers' wishes and their suppliers' goods. Within this production chain, however, farmers could also utilize distribution networks for goods, inputs, and knowledge that would have otherwise remained inaccessible. The changing place of the farmer in production chains presumably decreased the individual farmers' agency, but increased his ability to react to market changes and, ultimately, his innovativeness.

The increasing importance of international markets for products and inputs did not only change production chains; it also changed the role of knowledge. For long, Dutch farmers had produced their inputs themselves - seeds from previous harvests, manure from their own cattle, 
and animal feed from their own fields - or found their inputs relatively close to home: equipment from the local blacksmith, manure from the livestock-farming neighbour, or animal feed from the village retailer. Ongoing specialization increased the need for higher-valued inputs, which Dutch farmers could no longer produce themselves. Following the terminology of business economists, tasks previously done 'in-house' - or, to put it more accurately, 'onfarm' - were now 'outsourced'. The supply of inputs was handed over to (foreign) companies and was organized through formal and impersonal contracts rather than through local and informal barter exchange. Once relying on inputs produced locally or produced by the individual farmer as part of his 'farming system', increasingly more inputs were industrially or chemically produced by companies and institutes - produced 'off-farm', so to speak.

George Grantham, studying agricultural innovation in nineteenth-century Germany, has described this shift in terms of 'traditional innovation' and 'scientific innovation'. German farmers, Grantham argues, for long used locally-available inputs, which caused 'agricultural improvements to reflect materials locally available'. He contrasts this 'traditional innovation' to 'scientific innovation', which, defined in simple terms, is science applied to farming. Until the mid-nineteenth century this 'scientific innovation' was practiced by a small minority of large estate owners only, as the bulk of ordinary farmers still innovated 'traditionally'. With the increased usage of 'off-farm' inputs, innovation of a more 'scientific' nature became widespread. ${ }^{24}$

Grantham's concepts have their weaknesses. Innovation labelled 'scientific' often had a small knowledge base, especially with modern standards in mind. Innovation once regarded 'scientific' could be deemed 'traditional' by later generations. Moreover, 'traditional' could be misunderstood as underdeveloped or obsolete, even though 'traditional' innovation was often

\footnotetext{
${ }^{24}$ George Grantham, "The Shifting Locus of Agricultural Innovation in Nineteenth-Century Europe: The Case of the Agricultural Experiment Stations," in Technique, Spirit and Form in the Making of the Modern Economies: Essays in Honor of William N. Parker, ed. Gary Saxonhouse and Gavin Wright, Research in Economic History 3 (Greenwich and London: Jai Press, 1984), 191-214. Citation from 194.
} 
ingenious for its time. The terms 'scientific' and 'traditional', then, do not fully grasp the changing nature of agricultural innovation since the mid-nineteenth century. It might be more accurate to refer to 'locally-produced innovation' (or 'internally-produced innovation') and 'externally-produced innovation'. The first refers to innovation developed within the farming system or within the local community, the later refers to innovation produced by, among others, research institutes, companies, the food industry, and traders, that is, external to the individual farmer's farming system and outside his direct influence.

Table 2.2 The knowledge intensification of Dutch agriculture

\begin{tabular}{l|l}
\hline $\begin{array}{l}\text { Locally-produced innovation } \\
\text { 'Traditional innovation' }\end{array}$ & $\begin{array}{l}\text { Externally-produced innovation } \\
\text { 'Scientific innovation' } \\
\text { 'On-farm' inputs }\end{array}$ \\
$\begin{array}{l}\text { 'Off-farm' inputs } \\
\text { Knowledge exchange through tradition, } \\
\text { informal networks, village community, etc. }\end{array}$ & \begin{tabular}{l} 
traders, consultancy, cooperatives, etc. \\
\hline
\end{tabular}
\end{tabular}

The shift from locally-produced innovation to externally-produced innovation, summarized in Table 2.2, occurred gradually, and the two often coexisted. Yet, the growing relative importance of externally-produced innovation radically changed the role and nature of knowledge in agriculture. Knowledge on locally-produced innovation, exchanged through informal networks such as family ties and village communities, had been based on trial-and-error, personal observations, and farming traditions. This way of acquiring knowledge had been rather successful for generations without much formal education, agricultural research, or consultancy. With the rise of externally-produced innovation, however, this way of acquiring knowledge reached its limits.

Externally-produced innovation typically required more complicated, qualitatively different, and more diverse knowledge. To select the right kind of seed or artificial fertilizers, for instance, farmers required detailed information on various variables concerning their soils, their crops, and the chemical or biological build-up of their inputs. Although trial-and-error, 
personal observation, and informal networks remained vital tools - and still are - other channels to exchange knowledge had to be set up. As the following chapters reveal, with education, research institutes, public consultancy, cooperatives, and more, the Dutch government and the Dutch agricultural sector did exactly that.

\subsection{Conclusion}

This chapter has placed Dutch agricultural innovation in its international economic context and has shown that Dutch agriculture was influenced by international economic developments, particularly since the $1880 \mathrm{~s}$. Although Dutch agricultural products had been traded on international markets for centuries, the growth rates Dutch agricultural export experienced between the $1880 \mathrm{~s}$ and the end of the First World War were truly unprecedented. The Netherlands was not unique in exporting high-value products to industrializing countries in Europe, but the case of Dutch agricultural exports is set apart by its diversity. Dutch farmers exported dairy products as well as a wide range of rootcrops, vegetables, fruits, and seeds. The processing industry was not confined to producing cheese or butter, but also processed a wide variety of arable and horticultural products. The export-oriented nature of Dutch agriculture cannot be assigned to larger farmers only, but was a common feature of the entire sector.

The export orientation of Dutch agriculture caused Dutch farming to 'industrialize', as some might call it. Because this required an intensification of inputs and knowledge, the 'industrialization' of Dutch farming asked for a restructuring of the agricultural sector, with different organizations, different actors, and different (knowledge) networks. This restructuring came with the demand to generate knowledge and innovation that were applicable particularly to the Dutch case. Dutch agriculture had for long profited from innovation originating from elsewhere, but with the ongoing knowledge intensification and the increasing relative importance of high-value products this was no longer possible - Dutch agricultural innovation 
had to become self-sufficient. Part II of this study reveals how new networks and organizations were set up and how these contributed to Dutch agricultural innovation. First, though, the following chapter discusses the role of the Dutch government. 


\section{CHAPTER III}

\section{AGRICULTURAL INNOVATION IN ITS POLITICAL CONTEXT: \\ EXPLAINING INCREASED STATE INVOLVEMENT}

\subsection{Introduction}

While the previous chapter has discussed Dutch agricultural innovation in its international economic context, this chapter places Dutch agricultural innovation in its national political context. The relationship between farmers and states changed remarkably since the nineteenth century, when European states aimed to create conditions favourable for farming. The Dutch state, too, having funded research, education, and extension work, has received recognition from historians for its involvement in agriculture. ${ }^{1}$ Although Dutch agriculture has been heavily transformed by government involvement during the twentieth century, this cannot be said for the nineteenth century. Dutch state involvement in nineteenth-century agriculture, this chapter shows, was limited, especially when compared to other Western European countries. The Dutch state was relatively late in providing public agricultural education as well as publicly-funded agricultural research - a network of agricultural experiment stations was set up as late as the 1890s.

How can this relative backwardness be explained? Why did the government alter its policies? And how did Dutch agricultural state policy develop in following decades? By answering these questions, this chapter sheds light on the interplay between state involvement and agricultural innovation and argues that standard narratives about public agricultural policy do not capture the full story. One narrative, voiced by Michael Tracy, argues that states invested in agricultural education and research since 1880 to compensate for the lack of protectionism.

\footnotetext{
${ }^{1}$ See, for instance, Harro Maat, "Science Cultivating Practice. A History of Agricultural Science in the Netherlands and Its Colonies 1863-1986" (Wageningen University, 2001); D.J. Maltha, Honderd jaar landbouwkundig onderzoek in Nederland 1876-1976 (Wageningen: Centrum voor landbouwpublikaties en landbouwdocumentatie, 1976).
} 
Whereas many countries on the European continent supported their agricultural sector by taking protectionist measures, Denmark and the Netherlands are the well-known exceptions of states maintaining free trade while stimulating agricultural development through education and research. ${ }^{2}$ Another line of reasoning, introduced by Niek Koning, argues that the expansion of agricultural education and agricultural research since 1850 was a reaction to the decline of large landownership - 'the failure of agrarian capitalism', as Koning calls it - and the growth of small landownership, which states supported with better education and more research. ${ }^{3}$

This chapter argues that explanations for the development towards more state involvement in agricultural research and education should also take into account the changing nature of agricultural innovation. As the previous chapter has shown, Dutch agriculture was heavily dependent on imported inputs. The usage of imported artificial fertilizers increased rapidly. Traditional ways to acquire knowledge fell short and informal networks to diffuse knowledge no longer sufficed. In the absence of improved research, formal education, and widespread knowledge networks, the capital intensification led to market failures which the private sector could not solve by themselves. The state had to step in.

This chapter uses the following empirical material. Firstly, minutes of parliamentary meetings reveal what arguments parliamentarians had for (not) stimulating agricultural innovation. Secondly, the minutes of the 1886 State Committee on Agriculture, investigating how to recover from the Agrarian Depression, show how politicians and representatives of the Dutch farming population, united in this State Committee, thought about agricultural innovation. Thirdly, the voice of the Dutch farming population is captured by analysing two agricultural periodicals, the Vriend van den Landman ('Friend of the Countryman') and the

\footnotetext{
${ }^{2}$ Michael Tracy, Government and Agriculture in Western Europe, 1880-1988, Third Edition (New York: Harvester Wheatsheaf, 1989), 32, 110, 357.

${ }^{3}$ Niek Koning, The Failure of Agrarian Capitalism. Agrarian Politics in the United Kingdom, Germany, the Netherlands and the USA, 1846-1919 (London and New York: Routledge, 1994), 34-36.
} 
Landbouw-courant (literally 'Agriculture Newspaper'). ${ }^{4}$ Although these periodicals presumably attracted attention mainly from larger farmers, they nevertheless provide insight into the Dutch farming population and their relation to the Dutch state.

This chapter is structured as follows. After the following two sections describe (the lack of) Dutch agricultural education and agricultural research before circa 1870 and place this in an international perspective, section 3.4. presents explanations for the late state involvement in Dutch agriculture. Section 3.5. explains why the Dutch government suddenly decided to step in, after which section 3.6. follows the development of Dutch agricultural education and agricultural research in the following century. The last section concludes.

\subsection{Agricultural education until the 1870s}

State support for agricultural education and agricultural research took off in Western Europe after c. 1750. Since the eighteenth century, Europe experienced various outbreaks of rinderpest. The battle against this disease prompted governments throughout Western Europe to intervene, as this was a threat too great for farmers to deal with themselves. Governments took various legal measures, for instance forbidding the trade of cattle from contaminated regions, and set up veterinary schools to train veterinary doctors. ${ }^{5}$ The first veterinary schools were established in France in 1762 (Lyon) and 1767 (Alfort), soon followed by veterinary schools in Copenhagen (1773), Vienna (1777), Dresden (1778), Hannover (1784), Munich (1790), Berlin (1790), and London (1792). ${ }^{6}$ The emergence of veterinary schools coincided with the economic theories of physiocracy and cameralism gaining popularity among many European state rulers. Both economic theories, the first being French and the latter originating in the German-speaking

\footnotetext{
${ }^{4}$ The Vriend van den Landman appeared weekly from 1837 to 1873 and the Landbouw-courant appeared weekly from 1847 to 1878 and twice a week from 1878 to 1891 .

${ }^{5}$ C.A. Spinage, Cattle Plague. A History (New York: Kluwer Academic/Plenum Publishers, 2003), 241-50.

${ }^{6}$ Leen van Molle, "Kulturkampf in the Countryside. Agricultural Education, 1800-1940: A Multifaceted Offensive," in Land, Shops and Kitchens. Technology and the Food Chain in Twentieth-Century Europe, ed. Carmen Sarasua, Peter Scholliers, and Leen van Molle, CORN Publication Series 7 (Turnhout: Brepols, 2005), $139-69$
} 
lands, saw agricultural development as fundamental for a country's economic growth and welfare. State action was considered crucial to augment agricultural output and expand the economy. Economic progress was thought to be in the authorities' hands - a common idea in modern minds, but a novelty in the eighteenth century. ${ }^{7}$

The Dutch Republic did not join these developments. While enlightened absolutism changed the role of central governments in many Western European states, the Dutch Republic clung to its fragmented political system, with no central ruler. The lack of a central government and a strong civil service kept programs against the rinderpest locally-organized and resulted in limited funding or political willingness to establish veterinary education. It was only after the Dutch Republic was reformed into a centrally-organized kingdom that a veterinary school was established in Utrecht in $1821 .^{8}$

While France had led the way in veterinary education, more general agricultural education originated in the German-speaking lands. Since the mid-eighteenth century, German universities provided lectures in agrarian law and agricultural statistics. Because these lectures were considered too theoretical and academic for the vast majority of the farming population, agricultural education with a more practical nature was offered on the tertiary level at agricultural colleges (or 'academies'), of which the first were established in Celle (1802), Weihenstephan (1803), Möglin (1806), and Hohenheim (1818). Outside the German-speaking states, agricultural colleges followed in France at Roville (1819), Grignon (1826), and TroisCroix (1832), in Italy at Pisa (1834), and in England at Cirencester (1842). Whereas these first colleges were often established on a combined public-private initiative, colleges established in later decades were often fully funded by the state, for example the French Institut national

\footnotetext{
${ }^{7}$ Peter M. Jones, Agricultural Enlightenment. Knowledge, Technology, and Nature, 1750-1840 (Oxford: Oxford University Press, 2016), 14-24.

${ }^{8}$ A. Mathijsen, ed., The Origins of Veterinary Schools in Europe - a Comparative View (Utrecht, 1997), 62-68. See also C. Offringa, Van Gildestein naar Uithof. 150 jaar diergeneeskundig onderwijs in Utrecht., vol. Deel I: 's Rijksveeartsenijschool (1821-1918) Veeartsenijkundige Hoogeschool (1918-1925) (Utrecht: Rijksuniversiteit te Utrecht. Faculteit der diergeneeskunde, 1971).
} 
agronomique at Versailles (1848), the Danish Royal Veterinary and Agricultural College at Frederiksberg (1858), and the Belgian Institut agricole de l'Etat at Gembloux (1860). ${ }^{9}$

The German states also pioneered in agricultural education at the secondary level. From the 1820 s onwards, sons of German farmers could receive practice-oriented farming training at Landwirtschaftsschule (agricultural schools) and Ackerbauschule (arable farming schools). This example was followed in the 1840s in France with the creation of agricultural orphanages, fermes-écoles (farm schools), and écoles agricoles régionales (regional agricultural schools). In 1849 and 1850 also the Belgian government opened no less than twelve secondary agricultural schools, two horticultural schools, and an agricultural mechanical school. ${ }^{10}$ In Denmark, children from lower socioeconomic groups could receive education at what were called Folk High Schools. After the first was established in 1844, the number of Danish Folk High Schools increased especially in the 1860s, culminating in 65 schools with 4,000 students per year around $1880 .^{11}$

Agricultural education in Belgium, Denmark, France, and the German states was generally more advanced than agricultural education in the Netherlands and Britain. Apart from the Royal Agricultural College at Cirencester, British agricultural education was very limited, a situation changing after the 1890s only. By 1907, five agricultural colleges had been established, while nine university departments had become involved in agricultural science. ${ }^{12}$ In the Netherlands, publicly-funded agricultural education, on whatever level, had been absent

\footnotetext{
${ }^{9}$ E. Porceddu and R. Rabbinge, "Role of research and education in the development of agriculture in Europe," European Journal of Agronomy, no. 7 (1997): 1-13. Van Molle, "Kulturkampf in the Countryside. Agricultural Education, 1800-1940: A Multifaceted Offensive," 149-50. Michel Boulet, "1848, 1960: Two Laws for Agricultural Education in France. Essay on Comparisons between State's Methods of Intervention," in The State and Rural Societies. Policy and Education in Europe 1750-2000, ed. Nadine Vivier, Rural History in Europe 4 (Turnhout: Brepols, 2008), 247-52.

${ }^{10}$ Van Molle, "Kulturkampf in the Countryside. Agricultural Education, 1800-1940: A Multifaceted Offensive," 153.

${ }^{11}$ Jens Christensen, Rural Denmark, 1750-1980, trans. Else Buchwald Christensen (Copenhagen: The Central Cooperative Committee of Denmark, 1983), 81.

${ }^{12}$ P. Brassley, "Agricultural Education, Training and Advice in the UK, 1850-2000," in The State and Rural Societies. Policy and Education in Europe 1750-2000, ed. Nadine Vivier, Rural History in Europe 4 (Turnhout: Brepols, 2008), 260-63.
} 
for most parts of the nineteenth century. A first step in catching up with surrounding states only came with the founding of the Rijkslandbouwschool (State Agricultural College) at Wageningen in 1876. When comparing the founding year of this sole Dutch agricultural college with public agricultural colleges elsewhere in Europe (see Table 3.1), one can safely conclude that Dutch state funding for agricultural education came late. This delay is more apparent when taking into account that Table 3.1 only includes a selection of larger German states. Various smaller German states, with lower revenues and resources than the Dutch state, had followed the example of the larger German states since the mid-nineteenth century. The Dutch, however, only followed the example of their eastern neighbours in $1876 .{ }^{13}$

\section{Table 3.1. Public agricultural colleges in eight nineteenth-century European states}

\begin{tabular}{l|l|l}
\hline State & College & Founding Year \\
\hline Bavaria & Weihenstephan & 1803 \\
\hline Prussia & Möglin & 1806 \\
\hline Württemberg & Hohenheim & 1818 \\
\hline UK & Cirencester & 1842 \\
\hline Italy & Pisa & 1843 \\
\hline France & Versailles & 1848 \\
\hline Belgium & Gembloux & 1860 \\
\hline the Netherlands & Wageningen & 1876 \\
\hline
\end{tabular}

Source: Leen van Molle, "Kulturkampf in the Countryside. Agricultural Education, 1800-1940: A Multifaceted Offensive," in Land, Shops and Kitchens. Technology and the Food Chain in Twentieth-Century Europe, ed. Carmen Sarasua, Peter Scholliers, and Leen Van Molle, CORN Publication Series 7 (Turnhout: Brepols, 2005), 139-69.; Rossano Pazzagli, "From Private Initiative to State Intervention: The Origins of Agricultural Education in Italy," in The State and Rural Societies. Policy and Education in Europe 1750-2000, ed. Nadine Vivier, Rural History in Europe 4 (Turnhout: Brepols, 2008), 231-46.; Jonathan Harwood, Technology's Dilemma. Agricultural Colleges between Science and Practice in Germany, 1860-1934 (Bern: Peter Lang, 2005), 111-222.

While Dutch public agricultural education only gradually developed since the 1870 s, earlier decades had seen failed efforts to stimulate agricultural development more generally. The replacement of the decentralized Dutch Republic with the centralized Batavian Republic in

\footnotetext{
${ }^{13}$ Jonathan Harwood, Technology's Dilemma. Agricultural Colleges between Science and Practice in Germany, 1860-1934 (Bern: Peter Lang, 2005), 35-76.
} 
1795 had created opportunities for more top-down interventions. In 1799 the government created the Cattle Fund (Veefonds) to compensate farmers who had been compelled to slaughter their infected livestock. In 1805 this fund was expanded into the more encompassing Agricultural Fund (Landbouwfonds), which financed, among other things, the publication of agricultural statistics and the provincial 'Committees for Agriculture' (Commissies van Landbouw). The members of these provincial committees, mostly large landowners, were to advise the government on agricultural progress in their provinces. Although the provincial Committees for Agriculture survived times of political turmoil - in 1806 the Batavian Republic was replaced by the Kingdom of Holland, a client state of France, and in 1810 the Kingdom of Holland was formally integrated into Napoleon's Empire - their influence and significance declined in the following decades. They were abolished altogether in $1851 .{ }^{14}$

In 1815 , shortly after the founding of the new (and short-lived) United Kingdom of the Netherlands, the government granted chairs in agricultural economics (landhuishoudkunde, literally 'land-household studies') to the universities of Leiden, Utrecht, and Groningen. The lectures in landhuishoudkunde, considered too theoretical and too academic and with disappointingly low attendance rates, were not successful and were eventually dismantled in 1876. Apart from the chairs in landhuishoudkunde, the Dutch state did not provide any public agricultural education. ${ }^{15}$ A state committee, installed in 1856 to study the necessity of agricultural education, saw its advice for a public agricultural college ignored. In the 1840 s and 1850s various agricultural societies submitted requests for public agricultural colleges, but saw their requests declined. Despite intensifying calls from the Dutch farming population, the Dutch government restrained from intervening. ${ }^{16}$

\footnotetext{
${ }^{14}$ J. Bieleman, Boeren in Nederland. Geschiedenis van de landbouw 1500-2000 (Amsterdam: Boom, 2008), 3056.

${ }^{15}$ Maat, "Science Cultivating Practice. A History of Agricultural Science in the Netherlands and Its Colonies 1863 1986," 40-42.

16 J.M.G. van der Poel, Het Landbouwonderwijs in Nederland tot 1918 (Wageningen: Centrum voor landbouwpublikaties en landbouwdocumentatie, 1976), 32-35.
} 
Without government support, agricultural education in the Netherlands was fully dependent on private initiative. In 1842 a local agricultural society in Groningen, working together with the University of Groningen professor of landhuishoudkunde H.C. van Hall (1801-1874), established a private agricultural college. This private college, sporadically receiving state subsidies during the 1840s (fortunately, Van Hall's brother was the state secretary of finance during the 1840s), was attended by on average 35 students yearly and remained active until 1873, when falling numbers of students and complaints about the disappointing level of education prevented new funding. ${ }^{17}$ Another private agricultural college, established by a local horticultural society in 1867 , also had financial troubles and low amounts of students, eventually closing down in 1894 . Other private colleges were rare and short-lived: schools in Apeldoorn, Hengelo, Strijp, and Zalk were not more than farms where a few students boarded and received training, and had to close within a few years after opening. ${ }^{18}$

The failure of these private initiatives reveals that Dutch agricultural education in the nineteenth century could not survive without government support. New opportunities were seized, however, when the Dutch parliament confirmed the Secondary Education Act (Wet op het middelbaar onderwijs) in 1863. This Act prescribed that, apart from the already existing academic education at universities, the state was also to provide secondary and higher education of various professions, for instance technology, engineering, and shipping. Even though also public education for farmers was stipulated in the Act, public higher agricultural education was still not provided. Although the Act of 1863 did not directly result in higher agricultural education, it did stimulate agricultural education at the lower level, that is, non-theoretical, 'practical' farm training. The Act invited provinces, towns, and villages to apply for state grants.

\footnotetext{
${ }^{17}$ N.B. Goudswaard, Agrarisch onderwijs in Nederland, 1783-1983 (Culemborg: Educaboek, 1986), 101 and 140. Gerrie Koopman, Van Hall tot Heden. Tachtig jaar hoger agrarisch onderwijs in Groningen (1912-1992) (Groningen: REGIO-PRojekt Uitgevers, 1992), 16.

18 Goudswaard, Agrarisch onderwijs in Nederland, 1783-1983, 101, 140, 156-58. Van der Poel, Het Landbouwonderwijs in Nederland tot 1918, 35-44, 53-55.
} 
Even though various towns applied, merely two agricultural schools opened, in Warffum (1870) and Wageningen (1873), of which solely the school in Wageningen survived for longer than five years. ${ }^{19}$ The Wageningen application was successful because substantial portions of the expenses for the agricultural school were bared by the city of Wageningen, the province of Gelderland, and local agricultural societies, thus keeping the funding that had to be provided by the state to a minimum. ${ }^{20}$

The main problem the agricultural schools in Warffum and Wageningen encountered in their first years of existence was the lack of qualified teachers. Teachers had to be brought in from Germany, or Dutch prospective teachers had to enrol at German colleges. The Dutch government recognized that a college of higher agricultural education was needed, not so much to educate farmers, but to produce qualified teachers. Although the need for higher agricultural education was finally acknowledged, Dutch political leaders were not willing to extend the modest budget. The need to keep costs low gave the city of Wageningen the opportunity to negotiate with the government. Its recently-opened agricultural school was elevated to the nation's sole public agricultural college, the State Agricultural College (Rijkslandbouwschool), only because the city of Wageningen covered parts of the expenses. ${ }^{21}$ The development of Dutch agricultural education in the nineteenth century, once described as a 'long sequence of failures', had come into motion during the 1870 s, when the Dutch government finally stepped in, developing - though slowly - in the following decades. ${ }^{22}$

\footnotetext{
${ }^{19}$ Other towns and villages that applied for grants, but were rejected were Alkmaar, Apeldoorn, Breda, Dokkum, Franeker, Goes, Groningen, Haarlemmermeer, Nijmegen, Sneek, Tiel, Wieringerwaard, Winschoten, Winterswijk, and Zierikzee. Van der Poel, Het Landbouwonderwijs in Nederland tot 1918, 104-11.

${ }^{20}$ J. van der Haar, De geschiedenis van de Landbouwuniversiteit Wageningen. Deel I: van school naar hogeschool, 1873-1945 (Wageningen: Landbouwuniversiteit Wageningen, 1993), 43-45.

${ }^{21}$ Van der Haar, De geschiedenis van de Landbouwuniversiteit Wageningen. Deel I: van school naar hogeschool, 1873-1945, 54-57.

22 'De geschiedenis van het landbouwonderwijs [...] is een lang verhaal van een aaneenschakeling van mislukkingen.' ['The history of agricultural education is a long story of a sequence of failures'], quoted from Van der Poel, Het Landbouwonderwijs in Nederland tot 1918, 13.
} 


\subsection{Agricultural research until the $1870 \mathrm{~s}$}

While the Netherlands following neighbouring countries at a distance where agricultural education is concerned, this trend can also be recognized when looking at agricultural research. Throughout Europe, early forms of agricultural research were conducted by agricultural societies, within which estate owners discussed new machinery, techniques, and other innovations and sometimes these societies bought entire farm holdings to experiment with innovative farming. ${ }^{23}$ The first of these private experimental farms were established in Bechelbronn in France (1834) and Rothamstead in Britain (1843), both of which became models for experimental farms and experimental fields established by agricultural societies all over Europe. ${ }^{24}$

Because the experiments carried out by agricultural societies and by private experimental farms were often of a questionable scientific value, the origins of agricultural research are usually found in academic debates of the 1840s. German chemist Justus Liebig (1803-1873) popularized the idea that certain mineral nutrients - phosphorus $(\mathrm{P})$, nitrogen $(\mathrm{N})$, and potassium $(\mathrm{K})$ - are essential to plant growth. Liebig thus pleaded for the use of nitrogenbased fertilizers to compensate for the - falsely - assumed shortage of nitrogen in the air. The interest in nitrogen-based fertilizing brought together chemistry and agriculture and provoked a call to do chemical tests with fertilizers in laboratories. ${ }^{25}$ The first agricultural experiment station where these tests were done was established by the German state of Saxony in 1851,

\footnotetext{
${ }^{23}$ Van Molle, "Kulturkampf in the Countryside. Agricultural Education, 1800-1940: A Multifaceted Offensive," 148. Nadine Vivier, "European Agricultural Networks, 1750-1850: A View from France," in A Common Agricultural Heritage? Revising French and British Rural Divergence., ed. John Broad, The Agricultural History Review Supplement Series 5 (Exeter: British Agricultural History Society, 2009), 23-36.

${ }^{24}$ Giovanni Federico, Feeding the World. An Economic History of Agriculture, 1800-2000, Second Edition (Princeton: Princeton University Press, 2009), 106.

${ }^{25}$ William H. Brock, Justus von Liebig: The Chemical Gatekeeper (Cambridge: Cambridge University Press, 1997), 72-93. On the joining of chemistry and agriculture, see W. Krohn and W. Schäfer, "The Origins and Structure of Agricultural Chemistry," in Perspectives on the Emergence of Scientific Disciplines, ed. G. Lemaine et al., Maison Des Sciences de l'Homme, Paris Publications 4 (The Hague: Mouton \& Co., 1976), 27-52.
} 
after which other German states followed swiftly in the 1850s and 1860s, resulting in 44 German agricultural experiment stations by 1871 and circa 500 German agricultural experiment stations by $1900 .^{26}$

Other countries quickly imitated the German model. Agricultural experiment stations were established during the 1850 s and 1860 s in Denmark, Norway, Switzerland, and the Habsburg Empire, though the majority of these remained small and poorly funded. ${ }^{27}$ More extensive agricultural experiment stations were established in Sweden, where the first agricultural experiment station was established in Stockholm in 1861 and a second followed in Ultuna shortly afterwards. The Italian government aimed to stimulate its agricultural sector by creating a network of agricultural experiment stations with locations throughout the country: by 1877 , there were no fewer than sixteen different agricultural experiment stations in Italy. ${ }^{28}$ In Belgium, France, and Great Britain the government hesitated to become involved in agricultural research. The establishment of agricultural experiment stations in these countries largely depended on private initiative. Belgian large land owners united their interests in a society, the Association pour la Fondation de Stations Agricoles en Belgique, which made possible the establishment of agricultural experiment stations at Gembloux (1871), Ghent (1874), Liège (1878), and Hasselt (1878). ${ }^{29}$ French and British large landowners did not follow this example. Instead, they held on to the use of private experimental farms and experimental

\footnotetext{
${ }^{26}$ Ursula Schling-Brodersen, Entwicklung und Institutionalisierung der Agrikulturchemie im 19. Jahrhundert: Liebig und die landwirtschaftlichen Versuchstationen, Braunschweiger Veröffentlichungen zur Geschichte der Pharmazie und der Naturwissenschaften 31 (Braunschweig: Technische Universität, 1989), 248-49. The figure of 500 German experiment stations by 1900 is given by George Grantham, "The Shifting Locus of Agricultural Innovation in Nineteenth-Century Europe: The Case of the Agricultural Experiment Stations," in Technique, Spirit and Form in the Making of the Modern Economies: Essays in Honor of William N. Parker, ed. Gary Saxonhouse and Gavin Wright, Research in Economic History 3 (Greenwich and London: Jai Press, 1984), 192.

${ }^{27}$ Mark Russell Finlay, "Science, practice, and politics: German agricultural experiment stations in the nineteenth century" (Iowa State University, 1992), 308-22.

${ }^{28}$ Rossano Pazzagli, "From Private Initiative to State Intervention: The Origins of Agricultural Education in Italy," in The State and Rural Societies. Policy and Education in Europe 1750-2000, ed. Nadine Vivier, Rural History in Europe 4 (Turnhout: Brepols, 2008), 240.

${ }^{29}$ Lyvia Diser, "Laboratory versus Farm: The Triumph of Laboratory Science in Belgian Agriculture at the End of the Nineteenth Century,” Agricultural History, 86, no. 1 (Winter 2012): 31-54.
} 
fields that had been set up in earlier decades, such as the earlier-mentioned experimental farms in Rothamstead and Bechelbrom.

In the Netherlands, agricultural research for long was very limited. Without state involvement, testing and experimenting was done mainly by local agricultural societies and large landowners. Agricultural societies organized competitions, for instance awarding medals for breeding the most healthy cattle or for cultivating the most valuable crops, and set up exhibitions, during which new crop varieties and new tools could be displayed for the public. ${ }^{30}$ In 1860, local agricultural societies in the province of Overijssel jointly established a proeftuin (literally 'experimental garden') in Deventer, which tested the yields of new seeds. ${ }^{31}$ Tests and experiments were also conducted on a small scale by the veterinary school in Utrecht and by Van Hall's private agricultural college in Groningen. However, chemical knowledge and chemical experiments, as done at various agricultural experiment stations in Germany, were fully lacking in the Netherlands. ${ }^{32}$

This changed in 1877. When the State Agricultural College in Wageningen was established in 1876, Dutch political leaders were afraid that its curriculum would be too theoretical and would prevent Dutch farmers from having their sons trained in Wageningen. To free the State Agricultural College from its 'theoretical isolation', as it was called, an agricultural experiment station was attached to the college in 1877 , giving the college a more practice-oriented appearance. ${ }^{33}$ This State Agricultural Experiment Stations

\footnotetext{
${ }^{30}$ Dutch agricultural historian J.M.G. van der Poel has asserted that the innovations in which Dutch large farmers and agricultural were particularly interested usually concerned machinery. For a majority of the Dutch farming population, who did not own large estates, these innovations were probably far too costly. J.M.G. Van der Poel, Honderd jaar landbouwmechanisatie in Nederland, Agronomisch-Historische Bijdragen 11 (Wageningen: H. Veenman \& Zonen N.V., 1967), 185-201.

${ }^{31}$ Besides securing funds from local agricultural societies, the proeftuin received income by selling seeds and crops, for which it advertised in agricultural periodicals, 'Proeftuin te Deventer. Lijst der verkrijgbare zaden en gewassen', Landbouw-courant 16:49 (December 4, 1862).

${ }^{32}$ H.A.M. Snelders, "Landbouw en scheikunde in Nederland in de vóór-Wageningse periode (1800-1876)," AAG Bijdragen, 24 (1984).

${ }^{33}$ Van der Haar, De geschiedenis van de Landbouwuniversiteit Wageningen. Deel I: van school naar hogeschool, 1873-1945, 54.
} 
(Rijkslandbouwproefstation), simply called the 'Experiment Station of the State Agricultural College' in its early years and with its first director also being professor of chemistry, was not much more that the chemical laboratory of the agricultural college. ${ }^{34}$ While various countries had set up networks of agricultural experiment stations in previous decades, Dutch agricultural research was still in its infancy.

\subsection{Explaining the lack of state involvement}

The late state involvement in agricultural research and agricultural education in the Netherlands is remarkable, especially when taking into account the magnitude of the Dutch farming population. Around 1850, approximately $44 \%$ of the Dutch labour force was still active in the agricultural sector. Though a low number compared to France, Denmark, and the German states, this is still higher compared to Great Britain, where around 1850 merely $22 \%$ of the labour force worked in the agricultural sector. By the end of the century this percentage had dropped to $9 \%$, which might explain the British government's indifference with agricultural education and agricultural research. The Dutch government imitated this British policy of restricted government interference in agriculture, even though by 1900 still one third of the Dutch labour force worked in agriculture. ${ }^{35}$ How can this be explained?

Dutch political historians have accentuated that the liberal policy of the Dutch government during the nineteenth century received relatively little opposition. Within the Dutch agricultural sector it was acknowledged that the laissez faire policy was beneficial for agricultural trade. ${ }^{36}$ The agricultural periodicals analysed for this chapter show that it was argued that a more active state would lead to a higher tax burden, which would hit farmers hard.

\footnotetext{
${ }^{34}$ Maltha, Honderd jaar landbouwkundig onderzoek in Nederland 1876-1976, 49. M.B. Van Lennep, "De geschiedenis van het landbouwkundig onderzoek in Nederland," TNO Nieuws, no. 14 (1959): 103-9.

35 These figures come from B.R. Mitchell, European Historical Statistics 1750-1970 (London and Basingstoke: Macmillan, 1975), 153-63.

36 W.H. Vermeulen, Den Haag en de landbouw. Keerpunten in het negentiende-eeuwse landbouwbeleid, Staatkunde en Burgerschap 5 (Assen: Van Gorcum, 1966), 46.
} 
In 1860, for example, a reader of the Landbouw-courant commented that Dutch butter should receive state-authorized quality marks, guaranteeing its quality on international markets. ${ }^{37}$ Another reader responded that the quality of butter should be guaranteed by farmers themselves, without government interference. Stating that he feared 'all state interference in my profession', this reader argued that a growing state bureaucracy would intensify the tax burden, increase the butter price, and ultimately ruin the international competitiveness of the Dutch dairy sector. ${ }^{38}$ Although both readers agreed that the position on international markets was at stake, the first demanded state involvement while the latter saw state involvement as the root of the problem.

While some praised the passive position of the state towards agriculture, others suggested that this passiveness caused Dutch agriculture to be underdeveloped, as the government did not stimulate the rationalization of farming. The editors of the Vriend van den Landman and the Landbouw-courant were part of the small Dutch farming elite that advocated what was called 'scientific agriculture' or 'scientific farming'. Adherents of this ideal pleaded for the rationalization of farming by using theories from the natural sciences. For example, following Liebig's publications and reactions thereon in the 1840s, insights from chemistry were deemed applicable to determine soil fertility and to identify the most useful fertilizers. ${ }^{39}$

Besides news reports, statistical reports, and communiqués of agricultural societies, the Vriend van den Landman and the Landbouw-courant, aiming to pass on the ideal of 'scientific agriculture', dedicated a substantial number of articles to innovation in neighbouring countries. The editors translated foreign articles to republish in their own journal, to make their readers familiar with debates taking place abroad. The Vriend van den Landman, for instance, published

\footnotetext{
${ }^{37}$ J.R. van Maanen, 'De Nederlandse boterhandel, met betrekking tot Engeland' ['The Dutch butter trade with regard to England'] Landbouw-courant 14:16 (April 19, 1860).

${ }^{38}$ J.P. van Amersfoordt stated that '... I fear all interference of the state in my profession. I fear state officials, state formalities ...' ['... ik voor mij vreese alle bemoeijing van het Rijk met mijne nijverheid. Ik vrees Rijksambtenaren, Rijksformaliteiten...']. From JP. Van Amersfoordt, 'Certificaten van oorsprong voor boter', ['Certificates of the origins for butter'], Landbouw-courant 14:19 (May 10, 1860).

${ }^{39}$ E.C. Enklaar, the editor of the Vriend van den Landman, held a speech to a local agricultural society in 1842 entitled 'Verhandeling over de wetenschappelijke beoefening van de landbouw' ['Treatise on the scientific practice of agriculture'] (Zwolle 1842).
} 
various opinion essays which were copied from French and German periodicals and which praised the high development of British agriculture, portraying British agriculture as the standard to be imitated. ${ }^{40}$ Both periodicals kept their readership informed in detail on the rise of agricultural education and agricultural research in neighbouring countries. The Landbouwcourant started every issue with a column on reforms in agricultural education and agricultural research in neighbouring countries. Especially the setting up of agricultural colleges and agricultural experiment stations in Germany was given much attention. ${ }^{41}$

These international comparisons were made to accentuate the lack of state intervention in the Netherlands. When reporting about colleges or agricultural experiment stations being installed in the neighbouring countries, the periodicals would pose the question why the Dutch government did not follow this example. Besides comparisons with France, Germany, and Britain, developments in Belgium were followed with special interest; the - presumed backwardness compared to Belgium, having gained independence from the Netherlands in 1930, was described as particularly humiliating. ${ }^{42}$

The pleas for 'scientific agriculture' (and for government intervention to stimulate this), voiced by the agricultural periodicals as well as by many agricultural societies, did not have much direct effect. The articles in the periodicals - often highly theoretical, consisting of complicated chemical formulas, and containing reviews of equipment unaffordable for most give the impression that the agricultural periodicals were primarily by and for the farming elite. Their influence on the Dutch farming population as a whole should not be overestimated, and

\footnotetext{
40 'Schotland en Engeland als voorbeelden hoe de landbouw verbeterd kan worden' ['Scotland and England as examples of how agriculture can be improved'] Vriend van den Landman 15 (1851), 722-732; 'Hoe beuren wij onze landbouw op? Beschouwingen over den toestand van den landbouw in Groot-Brittannië' ['How do we build up our agriculture? Observations on the condition of agriculture in Great Britain'] Vriend van den Landman 6 (1842), 596-663.

${ }^{41}$ For instance E.C. Enklaar, 'Het landhuishoudelijk onderwijs in Duitschland' ['Agricultural education in Germany'] Vriend van den Landman 19 (1855), 740-743; 'Overzicht der landhuishoudelijke leer-inrigtingen in Pruissen' [Overview of agricultural education institutes in Prussia'] Vriend van den Landman 20 (1856), 181-182. ${ }^{42}$ For instance, 'Wat er door de Belgische regering voor den landbouw gedaan is', ['What the Belgian government has done for agriculture'], in: Vriend van den Landman 17 (1853), 686-689.
} 
the same goes for most of the nineteenth-century agricultural societies. Contemporaries complained that these were too elitist, too locally oriented and organized, and too weak to attract large numbers of farmers and to influence government policy. ${ }^{43}$ For example, the total membership of the largest nine provincial agricultural societies, it has been estimated, reached a peak of 30,000 members by 1880 . This is a low number, considering that there were approximately 100,000 Dutch farmers with at least one horse - and many more with no horse. Moreover, part of these 30,000 society members were local politicians, academics, absentee estate owners, or other urban elite who did not farm themselves.

The failure of agricultural societies and agricultural periodicals to promote scientific agriculture had its effect on political decision making. Parliamentary debates reveal that a majority of the Dutch parliament, dominated by liberal politicians adhering to limited state intervention, had little faith in scientific agriculture. During the debates about the Secondary Education Act of 1863, higher agricultural education was seen as unnecessary. Ordinary farmers, it was said, would see no good in education and scientific agriculture and would rather put their sons to work on the fields than have them receive 'scientific education', as one parliamentarian called it. ${ }^{44}$ 'Sons of farmers', one liberal parliamentarian stated, 'will always learn the conduct much better at home'. Skills in 'practical agriculture', which he contrasted to scientific agriculture, had been successfully passed on from generation to generation without any formal agricultural education and had brought Dutch agriculture success - so why change? $?^{45}$ The presumed success of scientific agriculture in neighbouring countries was

\footnotetext{
43 'Provincialisme in the 19e eeuw', ['Provincialism in the nineteenth century'], Landbouw-courant 22:41 (October $8,1868)$.

44 ،... Het zal nog veel moeijelijker zijn om den boer te bewegen zijne jongens wetenschappelijk onderrigt te doen geven. Let slechts op het bezoek der lagere school ten platten lande. Zoodra de kinderen eenigzins kunnen meewerken, worden zij van de school afgenomen.' ['... It will be much harder to convince the farmer to give his sons scientific education. Only note the attendance at primary schools on the country side. As soon as children can work, they are taken from school.'] Cited from 'Handelingen Tweede Kamer 1862-1863, 54e zitting, zitting van dinsdag 10 maart 1863', 592.

45 'De zoons van landbouwers zullen de praktijk altijd veel beter te huis leeren, en anderen, die bij 't vak overgaan op eene boerderij bij praktikale landbouwers, om aldaar zelf het boerenwerk, de gereedschappen en landbouwwerktuigen te hanteren.' ['The sons of farmers will always learn the conduct much better at home, and
} 
attributed to the efforts of large estate owners rather than to agricultural science and agricultural education - small farmers, the majority of the Dutch farming population, were not in need of agricultural education, so the Dutch parliament agreed upon. ${ }^{46}$ The success of Dutch agriculture during the nineteenth century removed the sense of urgency for reform.

Responding to the indifference of Dutch politicians, the agricultural periodicals blamed the weak bargaining position of agricultural interest groups. The few agricultural societies in the Netherlands, the agricultural periodicals complained, acted on a local level and represented local interests only. ${ }^{47}$ For example, when the government proposed to elevate the agricultural school in Wageningen to the state college in 1876, local agricultural societies from Groningen, lobbying for the state college to be located in their own province, tried to thwart the opening of the Wageningen college. They withheld their support as long as their preconditions for higher agricultural education were not met - preconditions which, they hoped, the government would not easily grant: perfect facilities, education in foreign languages, and an agricultural experiment station. ${ }^{48}$

Not pulling in the same direction, Dutch agricultural societies were unable to represent the agricultural sector at the highest level. A Dutch national agricultural society, comparable to for instance the Royal Agricultural Society in England, did not exist. Large estate owners with political influence, such as the British landed gentry, the Prussian junckers, or the Spanish propietaros, were rare. ${ }^{49}$ During the 1860 s and 1870 s, the agricultural periodicals show,

others, who get into the business, at a farm with practical farmers, to make use of the farmers' work, the equipment, and agricultural tools there themselves.'] Cited from 'Handelingen Tweede Kamer 1862-1863, 55e zitting, zitting van woensdag 11 maart 1863', 607.

46 'In andere landen, bepaaldelijk ook in Engeland, heeft het groote landbezit daartoe zeer veel bijgedragen. Die groote landbezitters, exploiteren daar zelven op groote schaal, hetgeen wij hier slechts op kleine schaal zien.' ['In other countries, especially also in England, large property ownership has contribution a lot to it. Those large property owners there exploit on a large scale, something we see here only on a small scale.'] Cited from 'Handelingen Tweede Kamer 1862-1863, 54e zitting, zitting van dinsdag 10 maart 1863', 594.

47 'Provincialisme in the 19e eeuw', ['Provincialism in the nineteenth century'], Landbouw-courant 22:41 (October $8,1868)$.

48 'Buitengewone vergadering ...' ['Extra meeting ...'], Landbouw-courant 30:30 (July 27, 1876).

49 Brassley, "Agricultural Education, Training and Advice in the UK, 1850-2000." Juan Pan-Montojo, "Landowners, Technicians and Associations: The Formation of the Agricultural Public Institutions in Spain, 18471936," in The State and Rural Societies. Policy and Education in Europe 1750-2000, ed. Nadine Vivier, Rural 
numerous initiatives to establish a national agricultural organization (which could act as an interest group for the entire Dutch agricultural sector) had failed. ${ }^{50}$ The agricultural periodicals published various pleas to establish a Chamber of Agriculture (Kamer van Landbouw), a public institute that could act as intermediary between the government and the sector - based on the Prussian model. ${ }^{51}$ The government, however, regarded a Chamber of Agriculture too costly. ${ }^{52}$

The Vriend van den Landman and the Landbouw-courant also complained that the Dutch government focussed on trade rather than on agriculture. Few politicians, it was argued, had an interest in agriculture. The periodicals regarded it unjustifiable that, even though farmers paid taxes as did everyone, the agricultural sector seemed the only sector of economy to be neglected. ${ }^{53}$ Politicians were excessively concerned with trade, it was claimed, because only a few members of parliament plead for the cause of farmers. ${ }^{54}$ During elections, the periodicals' readership was called to vote for candidates favourable for agriculture, and in 1866 the editor of the Landbouw-courant even presented a list of candidates for which, he thought, his readers should vote. ${ }^{55}$ After complaints about this voting advice, the editor defended himself by arguing

\footnotetext{
History in Europe 4 (Turnhout: Brepols, 2008), 112-16. Jonathan Harwood, "Research and Extension in Political Context: Rural Unrest and the Origins of the Prussian Chambers of Agriculture," in The State and Rural Societies. Policy and Education in Europe 1750-2000, ed. Nadine Vivier, Rural History in Europe 4 (Turnhout: Brepols, 2008), 147-52.

50 'Over 't voorstel van ééne landbouwmaatschappij over geheel Nederland' ['About the proposal for one agricultural society for the entire Netherlands'], Landbouw-courant 18:9 (March 3, 1864); 'Een voorstel aan alle landbouw-vereenigingen in Nederland' ['A proposal for all agricultural societies in the Netherlands'], in: Landbouw-courant 23:15 (April 15, 1869); 'Wat op het congres te Kampen over eene centrale landbouwvereniging gezegd is' ['What was said about one central agricultural society at the congress in Kampen'], Landbouw-courant 24:12 (March 24, 1870).

51 'Kamer van Landbouw' ['Chamber of Agriculture'] Landbouw-courant 28:28 (July 9, 1874).

${ }^{52}$ The government regarded a Chamber of Agriculture too costly, see 'Pruissen bezit een ministerie van landbouw; de magtige "Royal Agricultural College" in Engeland wenscht het - en de Nederlansche Tweede Kamer der StatenGeneraal weigert f. 1200 voor een rijks-collegie van landbouw' ['Prussia has a department of agriculture, the powerful "Royal Agricultural College" in England wants it - and the Dutch parliament refuses f. 1200 for a state body for agriculture'], Landbouw-courant 31:3 (January 18, 1877).

${ }^{53}$ For instance 'Over den achterlijken toestand van den landbouw in vergelijking met dien van handel en fabrijken' ['About the backward state of agriculture compared to trade and factories'] Vriend van den Landman 3 (1839), $556-571$.

54 'De landbouwer en de staat' ['The farmer and the state'], Landbouw-courant 16:20 (July 21, 1864).

55 'Verkiezingen. Een woord ter overweging' ['Elections. A consideration'] Landbouw-courant 18:20 (May 17, 1866).
} 
that farmers should participate in politics much more than they had been doing to better defend their interests. ${ }^{56}$

It is unclear to what extent these complaints in the agricultural periodicals reflect historical reality. Were Dutch politicians really not interested in agriculture? Dutch political historical studies have shown that the Dutch ruling class consisted primarily of the urban elite, which indeed did not have a large interest or stake in the agricultural sector. ${ }^{57}$ Political historian W.H. Vermeulen asserts that during the nineteenth century agriculture was not a much-debated topic in national politics, nor did it receive much attention in non-agrarian periodicals and general newspapers. Vermeulen suggests that other major topics, such as the enlargement of the franchise or the rise of socialism, might have cast aside agricultural issues. ${ }^{58}$ Although the agricultural periodicals may have overemphasized to be more persuasive, it is no exaggeration to say that, for long, agricultural education and agricultural research were not the government's top priority.

\subsection{Explaining the increase of state involvement since the $1870 \mathrm{~s}$}

The Dutch state was late in following the example of neighbouring countries in facilitating agricultural education and agricultural research because the Dutch agricultural sector during the nineteenth century had sufficient possibilities to improve their farming and to prosper economically - without state stimulation. Advocates of 'scientific agriculture', calling for the government to take the lead in agricultural education and agricultural research, lacked the bargaining power to change Dutch government policy. The closing decades of the nineteenth century saw this equilibrium collapse. How is this to be explained?

\footnotetext{
56 'Geen politiek in de Landbouw-courant!' ['No politics in the Landbouw-courant!'], Landbouw-courant 18:21 (May 24, 1866). The editors defence: 'Politiek in de Landbouw-courant' ['Politics in the Landbouw-courant'] Landbouw-courant 18:25 (June 21, 1866).

${ }^{57}$ R. van der Laarse, A Nation of Notables: Class, Politics and Religion in the Netherlands in the Nineteenth Century, Occasional Papers in the Contemporary History and Politics 3 (Salford: European Studies Research Institute, 2000), 3.

${ }^{58}$ Vermeulen, Den Haag en de landbouw. Keerpunten in het negentiende-eeuwse landbouwbeleid, 50.
} 


\section{Capital intensification}

Nineteenth-century globalization, Chapter 2 has shown, resulted in the increased usage of inputs imported from abroad. With seeds and fertilizers being shipped from abroad on an ever-large scale, 'traditional' ways of acquiring knowledge, which had been successful for centuries and which did not involve formal education, research, or consultancy, reached their limits. Family ties, village communities, and other informal networks, though still important in exchanging knowledge, were no longer sufficient. Individual farmers, who had previously used their own observations, trial-and-error, and tradition to determine, for instance, which crops to grow and which rotation system to follow, often lacked the know-how to deal with imported inputs. They used, for example, the wrong type of artificial fertilizer on the wrong kind of crop, they simply applied too large quantities of artificial fertilizers on their lands, or they led the fertilizers wash away and end up in the groundwater. Not fully aware of all the consequences artificial fertilizers could have, the intensifying application of artificial fertilizers was often devastating to soil and water quality. ${ }^{59}$ Because the Dutch government lacked the capacity to conduct chemical tests the agricultural experiment station that opened in 1877 was understaffed - the trade in artificial fertilizers went largely unchecked, making it possible to sell forged fertilizers. Some Dutch fertilizer traders would send samples to German or Belgian agricultural experiment stations to have their products qualified as reliable, hence securing their position on the Dutch fertilizer market. ${ }^{60}$ The late nineteenth-century capital intensification of Dutch agriculture, in sum, outgrew traditional ways of acquiring knowledge and brought market imperfections to the fore.

\footnotetext{
${ }^{59}$ J.L. van Zanden, "Mest en ploeg," in Geschiedenis van de techniek in Nederland. De wording van een moderne samenleving 1800-1890. Deel I: Techniek en modernisering. Landbouw en voeding, ed. H.W. Lintsen (Zutphen: Walburg Pers, 1992), 59-60.

${ }^{60}$ For instance 'Dr. Petermann's gunstig oordeel over de "opgelost-Peru-guano" van Ohlendorff \& Co. te Rotterdam' ['Dr. Petermann's favorable judgment on the "dissolved-Peru-guano" of Ohlendorff \& Co. in Rotterdam'] Landbouw-courant 27:11 (March 13, 1873).
} 


\section{Increased self-organization}

The market imperfections that resulted from the increased usage of imported seeds and artificial fertilizers had (at least) one result that would have a long-lasting effect on the development of Dutch agriculture in the following century. The capital intensification of farming caused smallscaled farmers to cooperate more than they had previously done. Whereas elite farmers had been gathering in agricultural societies since the early nineteenth century - presumably more out of a wish for exclusive group formation than out of direct economic need - smaller farmers only started organizing themselves from the 1870 s onwards, as revealed in the growing number of Dutch agricultural cooperatives. Although the Dutch agricultural cooperative movement cannot be explained by capital intensification alone, and although there is much more to be said about the origins, development, structure, and membership of Dutch agricultural cooperatives, an important objective for many cooperative was to give their members access to reliable inputs against lower prices. Working together, Dutch farmers could join in the capital intensification more effectively and could partly solve market imperfections.

\section{The decline of liberalism}

A third major transformation determining agricultural policy took place in the political sphere. Once dominated by liberal politicians and consequently by classic liberal values - laissez faire, limited state intervention, free trade, low taxes - Dutch politics went through a phase of rapid transformation during the last two decades of the nineteenth century. The dominance of classic liberalism came to an end and was replaced by the swift emancipation of various social groups hitherto barely represented, such as factory workers, Catholics, and orthodox Protestants. With the franchise being broadened step-by-step, Dutch politicians had to establish a firm foothold 
among the voting public. As a result, they were willing to reform education, social rights - and agriculture. ${ }^{61}$

The capital intensification of Dutch farming, the changes in the political sphere, and the increased self-organization of Dutch farmers coincided with the Agrarian Depression. While most Western European states reacted to the Agrarian Depression by imposing trade restrictions, the Dutch government held on to its free trade policy, as did Britain and Denmark. The topic of protectionism, as the agricultural periodicals reveal, was much debated by members of the Dutch agricultural sector itself. In 1885 the Landbouw-courant published a letter in which the editor of the periodical was accused of partiality: if the editor is so concerned about farmers as he claims to be, the writer asked, why not argue for protectionism? The editor defended himself by publishing an extensive list of Dutch agricultural societies and experts that were all against protectionism. Farmers with a preference for protectionism, the editor argued, were only a small minority. ${ }^{62}$ Even during the Agrarian Depression, it seems, the government's free trade policy was agreed upon by a majority of the Dutch agricultural population.

Although the Agrarian Depression apparently did not result in much opposition to free trade, it did bring the self-organization of Dutch farmers a step further, as Dutch agricultural societies and cooperatives started collaborating on the national level. After various initiatives to form national agricultural organizations failed, the Agrarian Depression gave this ideal new momentum, and a national body representing all agricultural societies and cooperatives was finally established in 1884. This Dutch Agricultural Committee (Nederlands LandbouwComité) quickly gained influence and convinced the Dutch government to investigate the role the state could play in recovery from the Agrarian Depression. To conduct this investigation a

\footnotetext{
${ }^{61}$ Remieg Aerts et al., Land van kleine gebaren. Een politieke geschiedenis van Nederland 1780-1990, 9th ed. (Nijmegen/Amsterdam: SUN, 2009), 149-53.

${ }^{62}$ H.D.S. Hasselman, 'Graanrechten of bescherming' ['Grain rights or protection'], in: Landbouw-courant 39:52 (June 28, 1885). This article includes the postscript in which the editor defends himself.
} 
special State Committee on Agriculture (Landbouwcommissie) was installed in 1886. This State Committee on Agriculture consisted of experts, such as the director of the agricultural experiment station in Wageningen and had people from the Dutch Agricultural Committee, representing the Dutch agricultural sector, as its members.

The minutes of the State Committee on Agriculture reveal that its members quickly agreed not to advise the government to take protectionist measures. Calling for protectionism, it was agreed upon, would merely cause discontent among politicians and could cause other recommendations by the Committee to be easily dismissed. ${ }^{63}$ Instead, the Committee advised to contribute to economic recovery by increasing the educational level of Dutch farmers, by improving the quality standards for export products (especially dairy products), and by solving market imperfections in the trade of inputs. The bargaining power of the individual Dutch farmer vis-a-vis the fertilizer trader had to be enhanced, as 'the farmer usually comes out on the losing end when dealing with private initiative', i.e. the trader in inputs. ${ }^{64}$ The State Committee on Agriculture argued that quality control for fertilizers, seeds, and feed was needed, and that this quality control could not be satisfied by the small experiment station in Wageningen alone. $^{65}$

The conclusions of the Committee were discussed in Dutch parliament on December 22, 1887. The Committee found little opposition and was praised for not advocating protectionism. Improving knowledge on fertilizers and other inputs was presented as a good alternative to regular trade protectionism. 'Here,' one politician stated, 'we have a case of healthy protectionism, not a protectionism that harms the great majority by the artificial increase of prices that only benefits a few, but a protectionism that enables farmers, by real increase of

\footnotetext{
${ }^{63}$ NL-HaNA, Landbouwcommissie, 2.11.25, inv. nr. 3. See the minutes of September 17, 1890.

64 ،... dat hier altijd 2 partijen zijn, landbouwer en koopman en de landbouwer gewoonlijk aan ' $t$ kortste eind trekt als hij te doen heeft met particulier initiatief' [' $\ldots$ there are always 2 parties, farmer and trader and the farmer usually comes out on the losing end when dealing with private initiative'], NL-HaNA, Landbouwcommissie, 2.11.25, inv. nr. 3. See the minutes of September 13, 1887.

${ }^{65}$ NL-HaNA, Landbouwcommissie, 2.11.25, inv. nr. 6.
} 
knowledge, to accept and manage competition with foreigners'. ${ }^{66}$ Better access to knowledge for the individual Dutch farmer, it was argued, would increase his international competitiveness. Once being 'fooled by the trade', Dutch farmers could 'arm themselves against deceit' by having their inputs checked by agricultural experiment stations. ${ }^{67}$ The critique that quality control could better be a private responsibility was easily dismissed by arguing that the reliability of the quality control could not be guaranteed by the traders themselves: 'private facilities are not to be trusted, because they let themselves be bribed by traders in seeds and fertilizers. Here only state officials can provide the necessary certainty. ${ }^{, 68}$ It was decided that quality control, and agricultural innovation as such, could not be left to the market alone. The state had to step in.

\subsection{The development of state involvement after 1890}

The Dutch government followed the advice of the State Committee of Agriculture to expand agricultural education and research. New agricultural experiment stations opened in Groningen, Hoorn, and Breda in 1890, followed by an agricultural experiment station in Maastricht in 1898. The agricultural experiment station in Wageningen was disconnected from the Wageningen agricultural college in 1892. It expanded swiftly and was divided into two separate agricultural experiment stations in 1899. Although conducting research was one of the core objectives of

\footnotetext{
66 'Hier hebben wij nu eens een geval van gezond protectionisme, niet een protectionisme dat de groote meerderheid benadeelt door kunstmatige verhooging van prijzen, die ten gunste van enkelen komen, maar een protectionisme dat den landbouwer in staat stelt, door zeer reëele verhooging van kennis, de concurrentie met buitenlanders te aanvaarden en te volbrengen.' 'Handelingen Tweede Kamer 1887-1888, $40^{\mathrm{e}}$ zitting, zitting van donderdag 22 december 1887', 627.

${ }^{67}$ 'De landbouwers worden zeer dikwijls door den handel gefopt; koopen zij zaden, meststoffen, lijnkoeken en dergelijke zaken, dan kunnen zij die laten onderzoeken aan de proefstations en zich op die wijze tegen bedrog wapenen' ['The farmers often get fooled by the trade; buying seeds, fertilizers, feedcakes, and such products, they can have them tested at experiment stations and arm themselves in that way against deceit']. Cited from 'Handelingen Tweede Kamer 1887-1888. 40 zitting, zitting van donderdag 22 december 1887, 634.

68 ‘... particuliere inrichtingen zijn niet te vertrouwen, want zij laten zich omkoopen door handelaars in zaden en meststoffen. Hier kunnen alleen ambtenaren de noodige zekerheid verschaffen.' Cited from 'Handelingen Tweede Kamer 1887-1888. $40^{\mathrm{e}}$ zitting, zitting van donderdag 22 december 1887', 632.
} 
the agricultural experiment stations, most resources were spent on control work, granting quality marks to seeds, fertilizers, and feeds.

Once deemed unnecessary, by the turn of the century state intervention in agricultural research and agricultural education had become one of the solutions to the problems. The emergence of agricultural experiment stations as well as the rise of cooperatives, agricultural organizations, and the agro-food industry - in other words, the 'professionalization' of the Dutch agricultural sector - stimulated the need for agronomists and other well-educated professionals. There were doubts, however, to what extent this need for more expertise could be met by the State Agricultural College in Wageningen alone. Especially after the agricultural experiment station in Wageningen was disconnected from the agricultural college in 1892, the agricultural college lacked the facilities to do much research. The State Agricultural College in Wageningen was criticized for not being the centre of agricultural research and higher agricultural education that it was required to be. 
Table 3.2 The main public agricultural institutes in the Netherlands, c. 1870-1950.

\begin{tabular}{|c|c|c|}
\hline Year & Institute & Location \\
\hline 1876 & State Agricultural College & Wageningen \\
\hline 1877 & Agricultural experiment station & Wageningen \\
\hline 1890 & Three agricultural experiment stations & Groningen, Hoorn, Breda \\
\hline 1898 & Agricultural experiment station & Maastricht \\
\hline 1899 & Agricultural experiment station & Wageningen \\
\hline 1905 & Institute for Farming Machinery & Wageningen \\
\hline 1906 & Institute for Plant Pathology & Wageningen \\
\hline 1912 & Institute for Plant Breeding & Wageningen \\
\hline 1919 & Experiment station for Forestry & Wageningen \\
\hline 1921 & Institute for Poultry & Beekbergen \\
\hline 1926 & Soil Science Institute & Groningen \\
\hline 1936 & Institute for Research on Fruit and Vegetables & Wageningen \\
\hline 1939 & Central Institute for Agricultural Research & Wageningen \\
\hline 1940 & Agricultural Economic Institute & The Hague/Wageningen \\
\hline 1943 & Institute for Breeding Horticultural Crops & Wageningen \\
\hline 1944 & Institute for Horticultural Machinery & Wageningen \\
\hline 1949 & Institute for Pathological Research & Wageningen \\
\hline 1949 & Institute for Agricultural Machinery and Rationalisation & Wageningen \\
\hline
\end{tabular}

Source: Maltha, Honderd jaar landbouwkundig onderzoek in Nederland 1876-1976, 105-107.

Responding to this criticism, a number of professors from the State Agricultural College took the initiative to established new research institutes: the Institute for Farming Machinery (1905), the Institute for Plant Pathology (1906) and the Institute for Plant Breeding (1912). All located in Wageningen and connected to the State Agricultural College, their directors were also professors at the agricultural college, and their facilities and resources were also used to train students and to advise farmers. ${ }^{69}$ Although the Wageningen institutes were at first excluded from doing control work on inputs, which was still mainly the responsibility of the agricultural experiment stations, their added value during this period is sometimes questioned. The Institute for Farming Machinery, for instance, mainly tested and displayed machinery imported from abroad, while the Institute for Plant Breeding had a too modest budget to connect to breeders and farmers. Since 1924 it published the yearly 'List of Varieties' (Rassenlijst), which reported

\footnotetext{
${ }^{69}$ A.P. Verkaik, Organisatiestructuur landbouwkundig onderzoek en achtergronden van haar totstandkoming (The Hague: Nationale Raad voor Landbouwkundig onderzoek TNO, 1971), 35.
} 
the yields, quality, and other characteristics of a wide range of varieties of the main Dutch crops. As such, the Institute for Plant Breeding had become a supervisory body rather than the research institute it was initially intended to be. ${ }^{70}$

At first, the research institutes and agricultural experiment stations mainly imported knowledge and innovations from abroad and tried to make these applicable to the Dutch context. Dutch agricultural research and agricultural education relied heavily on research done abroad, especially in Germany. Developments within Dutch agriculture, however, made clear that this no longer worked - specific Dutch problems required specific Dutch solutions. The unprecedented high usage of artificial fertilizers per hectare, for instance, demanded more knowledge about soil quality and the effects of artificial fertilizers. As a result, in 1926 part of the agricultural experiment station in Groningen was rearranged into the Soil Science Institute.

The growing capital intensification of greenhouse horticulture and its increasing relative importance for Dutch export was another characteristic of the Dutch agricultural sector that posed problems not easily solved. Because horticultural sectors elsewhere in Europe were often not as knowledge-intensive as their Dutch equivalent, knowledge on for instance the breeding of horticultural crops, the (refrigerated) transport of horticultural products, or the processing of horticultural products could not be imported from abroad. The Institute for Research on Fruit and Vegetables was established in 1936, followed by two more institutes concentrating on horticulture in the 1940s and five horticultural experiment stations in the 1950s.

While the Agrarian Depression of the 1870s and 1880s had proved to be a strong stimulus in the development of agricultural research and agricultural education, the same can be said for the Great Depression of the 1930s. Once again, stimulating the knowledgeintensification of Dutch agriculture was seen as a solution to falling prices and increasing international competition. The Dutch government centralized Dutch agricultural research -

\footnotetext{
${ }^{70}$ H. de Haan, “The History of the Plant Breeding Institute I.v.P. 1912-1962,” Euphytica, no. 12 (1963): 130-36.
} 
until the 1930s the agricultural experiment stations and the Wageningen research institutes had a large degree of freedom - by incorporating it more directly with the Ministry of Agriculture or with the 'Dutch Organisation for Applied Natural Sciences' (Nederlandse Organisatie voor Toegepast-Natuurwetenschappelijk Onderzoek, TNO), a public organisation formed in 1930 and set up to organize applied science.

Since the late 1930s, the Ministry of Agriculture and TNO both established various new research institutes, which contributed to a highly complex network with a wide range of public research institutes, experiment stations, and other research facilities. By around 1970, there were approximately 31 different research institutes conducting agricultural research, 25 of which (partly) located in Wageningen. ${ }^{71}$ The government's policy for agricultural innovation has become known as the OVO-drieluik (literally 'OVO triptych'), with OVO standing for 'onderzoek, voorlichting, onderwijs', (research, extension, and education). This policy was expanded especially after the Second World War, when the Ministry of Agriculture, usually dominated by conservative, confessional political parties, worked together closely with agricultural interest groups. This public-private collaboration, with its early origins in the 1890s, dominated the Dutch agricultural sector during the twentieth and became known, due to

\footnotetext{
${ }^{71}$ Verkaik, Organisatiestructuur landbouwkundig onderzoek en achtergronden van haar totstandkoming, 88-97.
} 


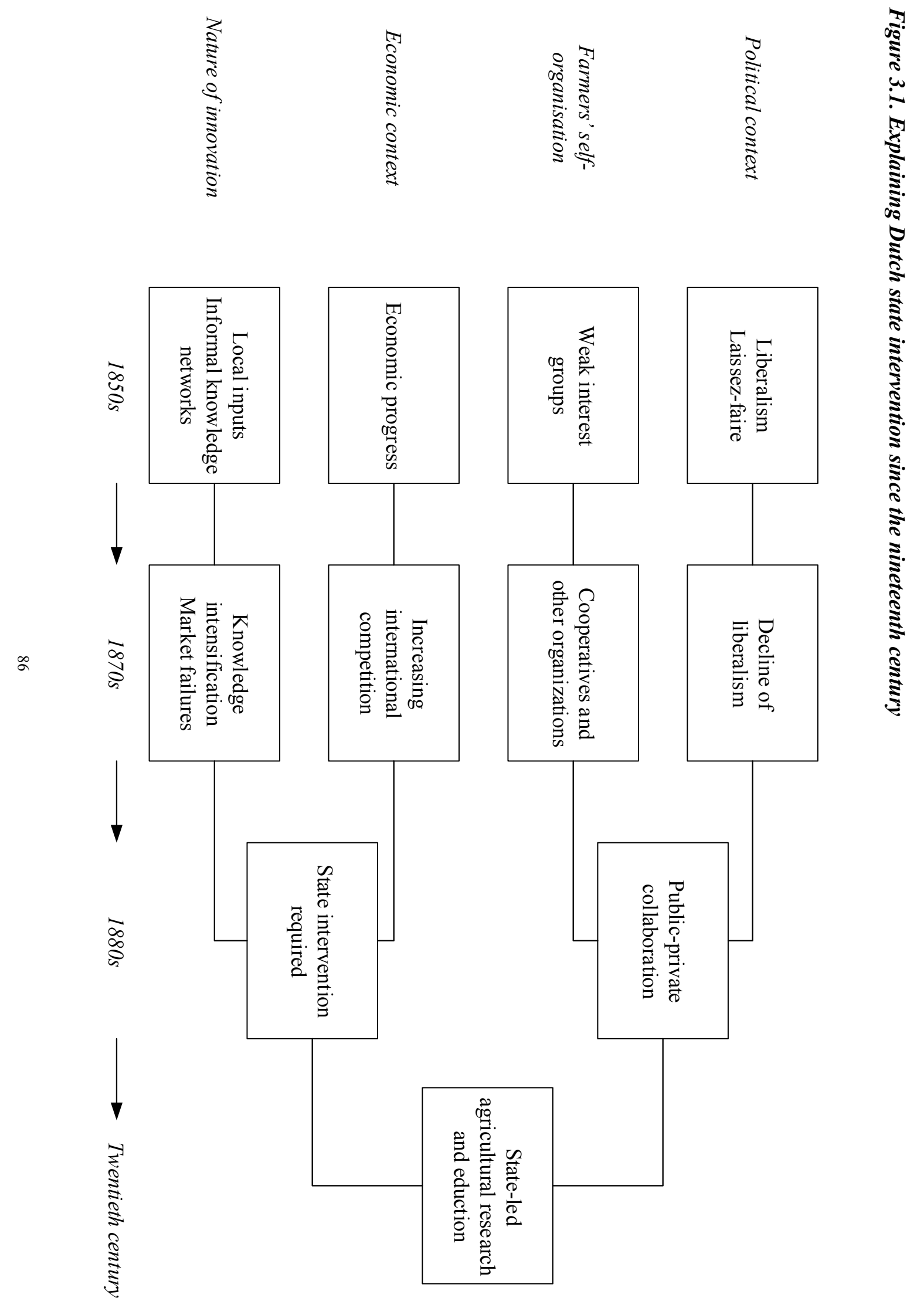


its apparent infrangibility, as 'the Green Front'. Dutch agricultural interest groups, once unable to make themselves heard, had become co-authors of government agricultural policy and influenced the course of Dutch agricultural innovation.

When looking back on the early origins and the subsequent development of state intervention in Dutch agricultural innovation, four pivotal developments can be discerned, as summarized in Figure 3.1. By around 1850, the political context was dominated by liberalism, advocating laissez-faire and limited state intervention. Because farmers did not organize themselves on a large scale, interest groups were weak. This combination, together with the fact that the Dutch agricultural sector was experiencing economic progress and that farmers innovated successfully by applying locally-available inputs and by using informal knowledge networks, made that state intervention was not needed or that the need for state intervention was not recognized or was not communicated convincingly. In the following decades, changes occurred in all these four fields: the Dutch agricultural sector went through a phase of knowledge intensification, which resulted in market failures; the period of economic progress was brought to a halt with the Agrarian Depression (increasing international competition remained an issue also after the Depression had gone); farmers started organizing themselves, locally as well as nationally; within the political context, lastly, liberalism was in decline.

Increasing international competition and market failures in the transfer of knowledge and inputs made that state intervention was required, more than ever. Changes in Dutch politics and the increased self-organization of the Dutch agricultural sector brought about a publicprivate collaboration, which recognized the need for state help. Together, this led to the formation and further expansion of public agricultural research and public agricultural education, from the nineteenth century deep into the twentieth. 


\subsection{Conclusion}

For the largest part of its history, farming in the Netherlands had been done in traditional ways. Dutch farmers had increased yields by fertilizing more intensively, had used locally available inputs, and had based their knowledge on their own observation and on what was passed on through informal networks. State involvement was not necessary. During the second half of the nineteenth century, however, Dutch agriculture started to transform drastically. A larger use of various inputs, often traded over long distances rather than found close by, revealed that traditional ways to gather and distribute knowledge were no longer sufficient. The farmers' capacity to acquire knowledge had reached its frontier, often with market imperfections as a result. Because these market imperfections could not be solved by the agricultural sector itself, the state was needed to step in.

For long the call for state intervention could not be communicated persuasively. Influential interest groups, which could have acted as the voice of the sector, were lacking. The Agrarian Depression gave an impulse to the self-organization of farmers, which culminated in the founding of the Agricultural Committee in 1884. Meanwhile, important transformations in the political arena - the decline of classic liberalism, the emancipation of various social groups, and the enlargement of the franchise - made that the receptiveness for the lobby of this Agricultural Committee had increased. The Dutch government decided to change its stance towards agriculture, and actively stimulated agricultural education and research. It resulted in a rapidly expanding network of public institutes that provided education and research to solve the market imperfections the Dutch agricultural sector was confronted with. The Dutch case, to conclude, shows that when explaining why and how state agricultural policy in the past developed, the ways in which farmers innovated is of great importance. The following chapter zooms in on one of the tools the Dutch government used to stimulate Dutch agriculture: stateled consultancy. 


\section{CHAPTER IV}

\section{FERTILIZERS AND PUBLIC AGRICULTURAL CONSULTANCY}

\subsection{Introduction}

Part I of this study has shown how increasing international trade and intensifying international competition spurred Dutch arable farmers to specialize in high-value crops and to increase the usage of imported inputs. The subsequent knowledge intensification transformed the knowledge exchange between farmers and various innovation-diffusing actors. Part II studies this changing knowledge exchange and investigates particular innovations as case studies. This fourth chapter explains how knowledge on artificial fertilizers was exchanged. A pivotal role, this chapter finds, was played by agricultural consultants funded by the Dutch state. The exchange of knowledge between these public agricultural consultants and farmer communities exemplifies how public-private collaboration contributed to agricultural innovation.

Artificial fertilizers are illustrative for the rapid knowledge intensification that agriculture experienced in large parts of the world in the last 150 years. While for centuries farmers had applied organic fertilizers, the late nineteenth-century Second Industrial Revolution made way for technological advancements that introduced artificial fertilizers. ${ }^{1}$ Arable farming has ever since depended significantly on the ability to transform scientific and theoretical knowledge on chemistry into applicable knowledge on the adoption of artificial fertilizers. To adopt artificial fertilizers successfully, farmers required detailed information about their fields (soil nutrients, acid content, groundwater level, etc.) as well as their crops (required water, required nutrients, root growth etc.). Artificial fertilizers, then, are emblematic not only of the

\footnotetext{
${ }^{1}$ This chapter distinguishes between organic fertilizers, artificial fertilizers, and chemical fertilizers. Organic fertilizers include fertilizers originating from living (or formerly living) matter, such as bones, human waste, manure, birds' excrement, compost, etc. Artificial fertilizers are fertilizers not originating from organic sources but extracted from mines or produced industrially, such as salpeter or slag. Chemical fertilizers are artificial fertilizers chemically extracted from nitrogen and hydrogen. For a historical overview, see Vaclav Smil, Enriching the Earth. Fritz Haber, Carl Bosch, and the Transformation of World Food Production (Cambridge, MA: The MIT Press, 2001).
} 
industrialization and knowledge intensification of farming, but also of the 'location-specific' nature of agricultural innovation.

Artificial fertilizers are also one of the main innovations in Dutch agricultural history. ${ }^{2}$ During the twentieth century the Netherlands became the largest user of artificial fertilizers per hectare in Europe - and possibly worldwide. As shown in Table 4.1, in 1870 and 1880 Dutch agriculture was still only a small user of artificial fertilizers compared to Belgium, Germany, and Britain. Since 1880, however, the use of artificial fertilizers by Dutch farmers expanded rapidly, with the usage of artificial fertilizers on Dutch arable land more than doubling between the 1930 s and the 1980 s.

Table 4.1. Use of artificial fertilizers in seven countries, 1870-1985 (1870-1910 in kg per hectare of total farmland and 1913-1985 in $\mathrm{kg}$ per hectare of arable area).

\begin{tabular}{lrrr|rrr}
\hline Country & $\mathbf{1 8 7 0}$ & $\mathbf{1 8 8 0}$ & $\mathbf{1 9 1 0}$ & $\mathbf{1 9 1 3}$ & $\mathbf{1 9 3 6}$ & $\mathbf{1 9 8 5}$ \\
\hline The Netherlands & 0 & 1 & 36 & 146 & 320 & 784 \\
Belgium & & 9 & 47 & 65 & 172 & 522 \\
Germany & & 4 & 29 & 47 & 64 & 427 \\
Great Britain & 5 & 7 & 9 & 26 & 44 & 356 \\
France & 2 & 2 & 11 & 18 & 35 & 301 \\
Denmark & 0 & 1 & 9 & 18 & 62 & 242 \\
US & & & & 6 & 8 & 94 \\
\hline
\end{tabular}

Source: For the years 1870 and 1880, J.L. van Zanden, "The First Green Revolution: The Growth of Production and Productivity in European Agriculture, 1870-1914," Economic History Review 44, no. 2 (1991): 215-239, 224. For the years 1910-1985, Merijn Knibbe, "Feed, Fertilizer and Agricultural Productivity in the Netherlands, 18801930," Agricultural History, 74, no. 1 (2000): 39-57, 55.

The staggering figures above impose two questions. First, what explains the massive increase in Dutch artificial fertilizer usage? And second, how did Dutch farmers obtain the knowledge to fertilize their fields effectively - how did they know, for instance, when, how, and which fertilizers were to be used on their fields? The answers to these questions are intertwined: the

\footnotetext{
${ }^{2}$ J. Bieleman, Boeren in Nederland. Geschiedenis van de landbouw 1500-2000 (Amsterdam: Boom, 2008), 282 and J.L. van Zanden, De economische ontwikkeling van de Nederlandse landbouw in de negentiende eeuw, 18001914, AAG Bijdragen 25 (Wageningen, 1985), 252.
} 
increase in Dutch artificial fertilizer usage during the twentieth century cannot be separated from the improving exchange of (and access to) knowledge. The knowledge exchange, this chapter shows, improved over time due to the efforts of public agricultural consultants particularly. The improved knowledge exchange is itself one of the explanations for the magnitude of Dutch artificial fertilizer usage: increasing familiarity and decreasing information asymmetry persuaded Dutch farmers to apply artificial fertilizers abundantly.

This chapter is structured as follows. In section 4.2 trade data quantify the usage of artificial fertilizers. ${ }^{3}$ Agricultural statistics then detect regional variation, which reveals that the large upswing in Dutch artificial fertilizer usage in the first decades of the twentieth century can partly be explained by farmers in the less developed regions (the in-land sandy regions dominated by small-scaled farming) following farmers in the other, more developed regions, which had turned to artificial fertilizers earlier. ${ }^{4}$ Section 4.3 , reviewing the various channels through which knowledge was transferred, highlights the important role of Dutch public agricultural consultancy. Hereafter, section 4.4 uses archival material of Dutch public agricultural consultancy to narrate its development since the $1890 \mathrm{~s} .{ }^{5}$ An international comparison in section 4.5 reveals that Dutch public agricultural consultancy was wellorganized compared to equivalents elsewhere in Western Europe. Section 4.6 uses one particular Dutch agricultural consultant as a case study to shed light on the exchange of knowledge between consultants and farmers. The last section concludes.

\footnotetext{
${ }^{3}$ These trade data come from Dutch national trade statistics, Statistiek van den Uit-, In-, en Doorvoer, which were discussed in more detail in Chapter 2.

${ }^{4}$ These agricultural statistics come from Verslagen van den Landbouw, which are annual statistical reports on Dutch agriculture published by the Dutch government.

${ }^{5}$ This archival material is found in the archival records of the Directory of Agriculture: NA, 2.11.01, Directie van de Landbouw: Afdeling Akker- en Weidebouw, 1896-1962.
} 


\subsection{Explaining the increase in fertilizer usage}

Relatively high population densities in the Netherlands had caused Dutch farmers to be large users of fertilizers since as early as the Middle Ages. ${ }^{6}$ Usage and prices of fertilizers increased continuously in the following centuries due to the enduring pressure on land. Farmers consequently turned to compost, urban waste, bones, clay, fish, and other organic substitutes for manure which, they hoped, would increase yields. Nevertheless, by 1880 the costs for fertilizers were estimated to be about one-third of farmers' entire production costs. ${ }^{7}$

Without much quantitative evidence, Dutch trade statistics are the main entry to get a crude picture of Dutch artificial fertilizer usage. Graph 4.1 portrays the import and export of organic fertilizers and artificial fertilizers and reveals that the rapid rise in artificial fertilizer imports occurred since the 1880 s. Until the 1870 s the Netherlands had been a net exporter of organic fertilizers (compost, manure, urban waste, etc.), while the net imports of artificial fertilizers, in this period mainly salpeter, were still relatively small ${ }^{8}$ Prior to the 1870 s, Dutch farmers were not heavily dependent on imported artificial fertilizers, instead relying on domestically-produced organic fertilizers.

This changed after the 1870s. The Netherlands swiftly turned from an exporter into an importer of organic fertilizers, while the net imports of organic fertilizers grew hundred-fold between the early 1870 s and the early 1900s. Hereafter these imports dropped again, to turn into net exports in the 1920s. This decline coincided with the great increase of artificial fertilizer imports - from 167 tons in the late 1860 s to more than a million tons in the late 1920 s. This

\footnotetext{
${ }^{6}$ B.H. Slicher van Bath, De agrarische geschiedenis van West-Europa, 500-1850, Sixth Edition (Utrecht: Spectrum, 1987), 267-78.

${ }^{7}$ The price of urban waste from the city of Groningen, for instance, increased from on average 40.32 guilders per last between 1799 and 1822 to on average 87 guilders between 1870 and 1879 , with a peak of 99.30 guilders in 1876. Also the price of compost increased - from 30 to 40 guilders per shipload around 1810 to 92 guilders per shipload in the 1870s. Van Zanden, De economische ontwikkeling van de Nederlandse landbouw in de negentiende eeuw, 1800-1914, 233. Bieleman, Boeren in Nederland. Geschiedenis van de landbouw 1500-2000, 433.

${ }^{8}$ An exception on the net export of organic fertilizers is guano, a birds' excrement found on the Latin American shores and popular among farmers for its relative high content of nutrients. From the 1840 s to the 1870 s the net import of guano increased from 260 tons in the late 1840 s to around 10,000 tons in the late 1870 s, after which it dropped, fluctuating between 2,000 and 3,000 tons between the 1880 s and the 1900 s.
} 
tremendous growth in artificial fertilizer imports epitomizes the swift knowledge intensification of Dutch agriculture and the heavy dependence on artificial fertilizers.

Graph 4.1. Net imports and exports of fertilizers, 1846-1940 (in tons and 5-year averages, on log. scale)

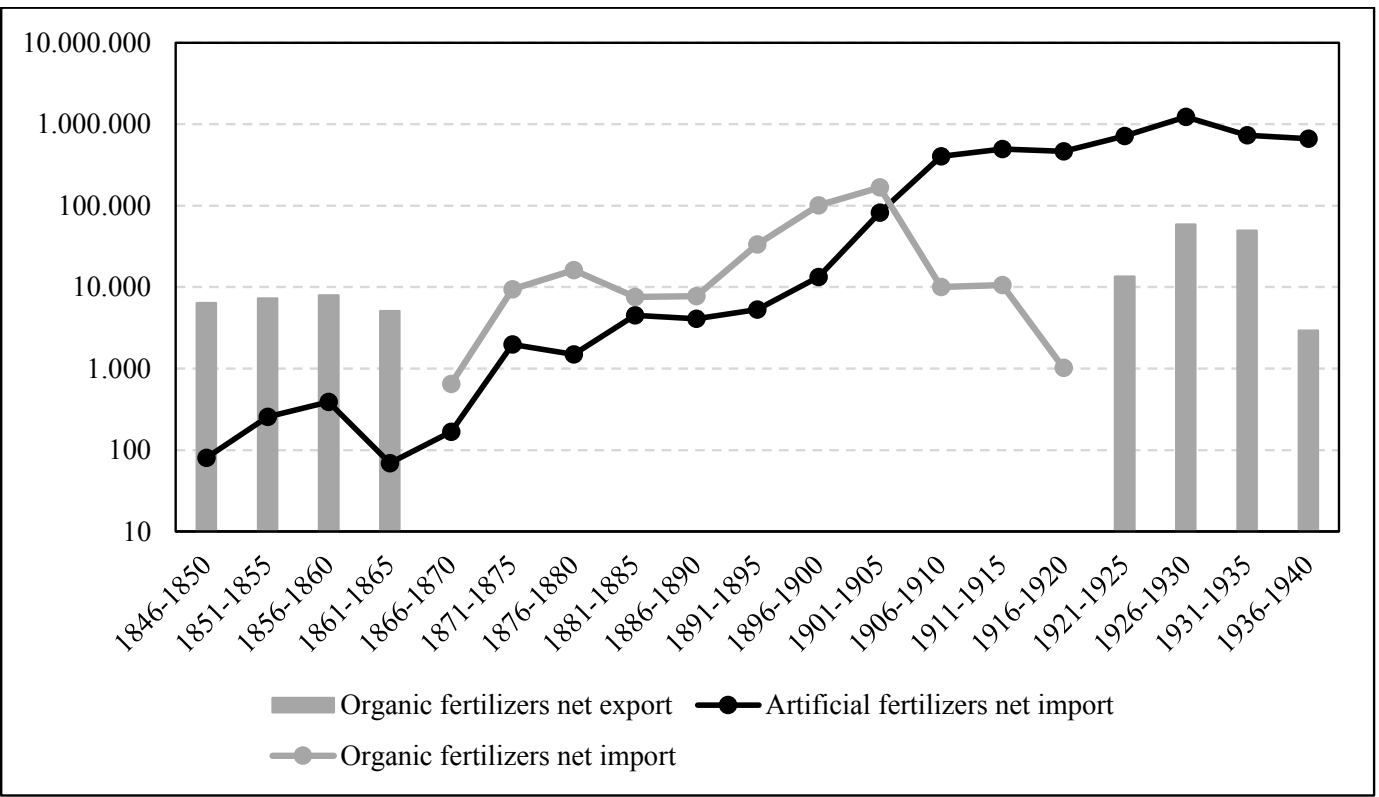

Source: SIUD, 1846-1940.

Note: Organic fertilizers include 'Stalmest', 'Secreetmest', 'Compost', 'Beer', 'Organische stikstofhoudende meststoffen (ledermeel e.a.)' and 'Beenderenmeel'. Artificial fertilizers include 'Superphosphaat', 'Thomasphosphaat (Thomasslakkenmeel)', 'Ruwe phosphaat', 'Chilisalpeter', 'Geraffineerde salpeter', 'Ruwe salpeter', 'Kalksalpeter', 'Kalisalpeter', 'Leunasalpeter', 'Kalkammonsalpeter', 'Salpeterzuur', 'Zwavelzure ammoniak', 'Kalkstikstof of stikstofkalk', 'Ureum', 'Kaïniet', 'Carnalliet', 'Zwavelzure kali', 'Chloorkali', 'Kalizout', 'Patentkali', 'Kalibemestingszout 20\%', 'Kalibemestingszout 40\%', 'Kunstguano', 'Schuimaarde', 'Andere hulp- en kunstmest'.

The figures in Graph 4.1 should be treated with caution, as Dutch international trade statistics provide no insight into domestic trade and production. During the nineteenth century Dutch production of artificial fertilizers was presumably small, as the Netherlands lacked heavy industry. In 1920, however, the main Dutch mining company (Dutch State Mines, DSM) started marketing nitrogen-rich by-products, mainly ammonium sulphate (zwavelzure ammoniak). In 1929 this example was followed by Hoogovens, the main Dutch steel company, and by Compagnie Néerlandaise de l'Azote, (CNA), a nitrogen fertilizer factory connected to a coking plant. Although producing largely for the world market, these three companies had the 
marketing strategy, through advertising and counselling, to increase the application of nitrogen fertilizers in particular among Dutch arable and livestock farmers, in which the companies allegedly succeeded. ${ }^{9}$ Because estimates of Dutch artificial fertilizer usage in the first half of the twentieth century are often based largely on net imports and exclude domestic production, these estimates are presumably too conservative: the trade statistics as found in Graph 4.1 are probably lower-bound figures. This means that Dutch artificial fertilizer usage was (even) larger than the estimates suggest. ${ }^{10}$

The enormous increase in Dutch artificial fertilizer usage is of too large a magnitude to be explained by one single cause. Various factors have to be taken into account. Graph 4.2 presents an index of the average price for various artificial fertilizers at the Centraal Bureau (the largest Dutch overarching supply cooperative that dominated the Dutch fertilizer market) and relates these prices to the average price for the main arable crops (potatoes, sugar beets, and wheat). Although the relative prices of artificial fertilizers certainly declined - by 1940 they had dropped with almost $60 \%$ compared to 1900 - they only did so after the First World War, while the increase in Dutch artificial fertilizer usage had taken off in earlier decades. Although falling prices certainly played a role by reducing the financial risk, particularly when bearing in mind that Graph 4.2 does not take into account the improving quality of artificial fertilizers - by 1940 they were cheaper as well as more reliable than in 1900. Falling prices do not fully explain the rise in Dutch artificial fertilizer usage before the First World War.

\footnotetext{
${ }^{9}$ Ernst Homburg, Groeien door kunstmest. DSM Agro 1929-2004 (Hilversum: Verloren, 2004), 16-23, 32-44.

${ }^{10}$ One of these (probably lower bound) estimates based on imports are the series presented by Knibbe: Merijn Knibbe, Agriculture in the Netherlands 1851-1950. Production and Institutional Change (Amsterdam: NEHA, 1993), 286. These estimates have ended up in the Dutch national statistics and in textbooks. 111 Jaar Statistiek in Tijdreeksen (The Hague: CBS, 2010), 96 and 98.; Bieleman, Boeren in Nederland. Geschiedenis van de landbouw $1500-2000,465$.
} 
Graph 4.2 Index of prices for artificial fertilizers from the Centraal Bureau relative to prices for wheat, potatoes, and sugar beets, 1900-1940 (1900=1).

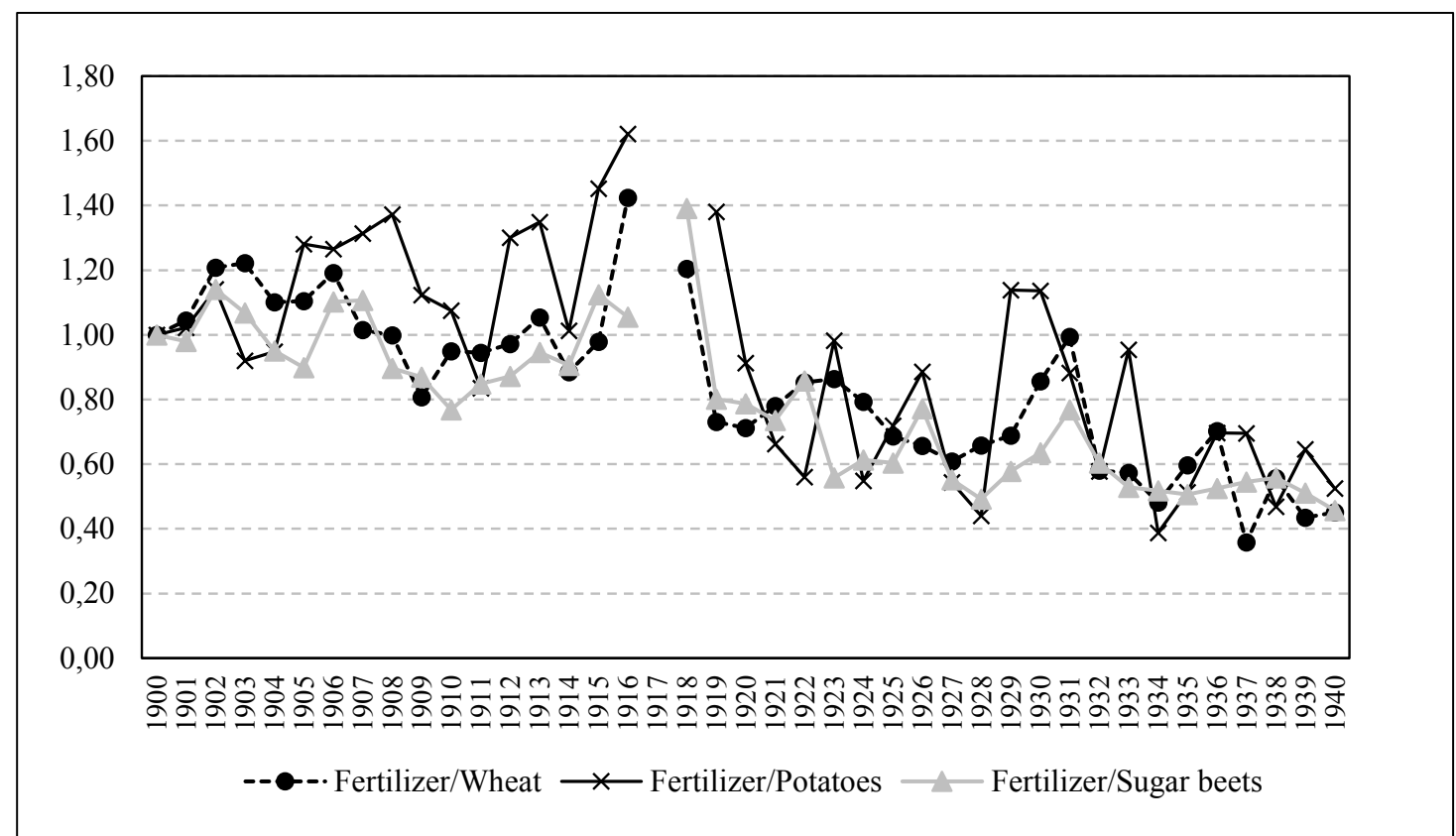

Source: Prices for artificial fertilizers at the Centraal Bureau come from VvdL 1900-1940. These prices are the average of the prices for 'Chilisalpeter', 'Zwavelzuren ammoniak', 'Kalksalpeter', 'Kalkammonsalpeter', 'Kaïniet', 'Kalizout 20\%, 'Kalizout 40\%', 'Thomasphosphaat' and 'Superphosphaat'. Prices for wheat, potatoes, and sugar beets come from Knibbe, Agriculture in the Netherlands 1851-1950, 248-249.

Besides prices, also factor endowments have played a role. When explaining the different trajectories of what he calls "Europe's Green Revolution" (circa 1870-1910), J.L. van Zanden notes that 'the innovations that were adopted by farmers in those countries [Belgium and the Netherlands, HZ], notably chemical fertilizers and purchased feed stuffs were typically land saving, and these innovations proved to be extremely important for the growth of agricultural production by freeing it from its most important bottle-neck, the scarcity of land'. ${ }^{11}$ According to Van Zanden, the land-saving characteristics of artificial fertilizers explain its rapid diffusion in the Netherlands and Belgium, Europe's most densely populated countries.

\footnotetext{
11 J.L. van Zanden, "The First Green Revolution: The Growth of Production and Productivity in European Agriculture, 1870-1914,” Economic History Review, 44, no. 2 (1991): 216.
} 
Merijn Knibbe, however, argues that artificial fertilizers also saved labour. Collecting and spreading animal manure was labour intensive, whereas many substitutes for manure carried unwanted weed seeds, making weeding more time-consuming. The main effect of the diffusion of artificial fertilizers during the second half of the nineteenth century, Knibbe asserts, 'was not an increase in available plant nutrients and yields. It gave farmers the option to change farming systems, to specialize in crop production, and to save on paid as well as family labor'. ${ }^{12}$ According to Knibbe, the diffusion of artificial fertilizers stems from the shift from wage labour to family labour.

The enormous usage of artificial fertilizers by Dutch farmers cannot be attributed to falling prices and changing factor endowments alone. Also other developments have to be taken into account. Continuing international competition, as discussed in Chapter 2, caused a shift from grains to higher-value products, mainly root crops and vegetables. These crops typically required more fertilization than grains. The growth in artificial fertilizer usage also coincided with the increase of the processing industry. Ties to sugar beet factories, potato starch factories, and straw board factories, to name but a few, gave Dutch farmers easy access to inputs. Since the 1880 s Dutch farmers also established supply cooperatives to jointly order fertilizers and other inputs. As such, the bargaining power of farmers vis-a-vis the fertilizer industry improved, particularly after the supply cooperatives jointly formed overarching cooperatives to organize the trade at the international level. Both the expanding processing industry and supply cooperatives provided the infrastructure that gave access to a wide variety of artificial fertilizers. ${ }^{13}$

\footnotetext{
${ }^{12}$ Knibbe extends his reasoning as far as connecting the diffusion of artificial fertilizers to school attendance of farmers' children: '[the introduction of artificial fertilizers] affected family life by increasing the possibilities for children to attend school.' Merijn Knibbe, 'Feed, Fertilizer and Agricultural Productivity in the Netherlands, 1880 1930," Agricultural History, 74, no. 1 (2000): 55-56.

${ }^{13}$ For a history of supply cooperatives and of the Centraal Bureau, see J.H. Van Stuijvenberg, Het Centraal Bureau. Een coöperatief krachtveld in de Nederlandse landbouw 1899-1949 (Rotterdam, 1949); Hans Veldman, Eric van Royen, and Frank Veraart, A Powerful Partner in Dutch Agriculture and Horticulture. The History of Cebeco-Handelsraad, 1899-1999 (Rotterdam: Foundation for History of Technology, 1999); Ronald Rommes,
} 
Problematic in trying to explain the increase in artificial fertilizer usage is circular causality. Artificial fertilizer usage increased due to the shift from grains to root crops and vegetables, but this shift itself was made possible through an increased availability of artificial fertilizers. In a similar vein, were supply cooperatives a result of the diffusion of artificial fertilizers, or its cause? This problematic reasoning might be partially solved by looking at regional variation.

Graph 4.3. Cooperative purchases of fertilizers in the pasture provinces, the arable provinces, and the mixed provinces, 1904-1924 (in total tons and in guilders per $100 \mathrm{ha}$ ).

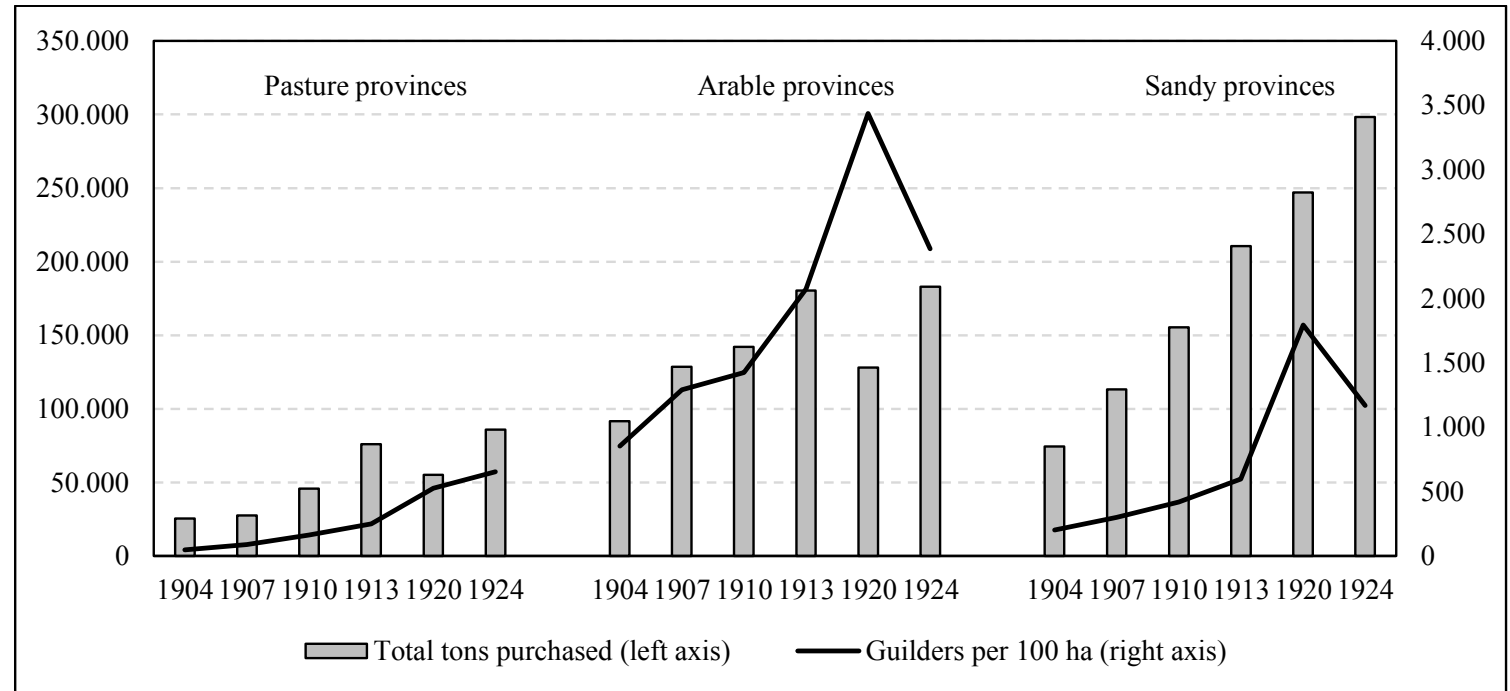

Source: VvdL 1905, 1908, 1911, 1914, 1921, and 1924.

Graph 4.3 presents the purchase of fertilizers by supply cooperatives (in total tons as well as guilders per 100 hectare) in a couple of years between 1904 and 1924 for three sets of Dutch regions. In the pasture provinces (Friesland, Utrecht, Noord-Holland, and Zuid-Holland) the cooperative purchase of fertilizers was low: livestock farming required little fertilizing and the presence of large cattle herds resulted in an abundance of animal manure. In these areas less than 500 guilders was spent on artificial fertilizers per 100 hectares of land. The sea clay areas

Voor en door boeren? De opkomst van het coöperatiewezen in de Nederlandse landbouw vóór de Tweede Wereldoorlog (Hilversum: Verloren, 2014). 
of Zeeland and Groningen and the peat colonies (the Veenkoloniën) in Groningen and Drenthe, jointly referred to in Graph 4.3 as the arable provinces, were the largest users of artificial fertilizers. Here, farmers reached high levels of specialization and pioneered in artificial fertilizer usage. From 1904 to 1924 expenditure on artificial fertilizers per 100 hectares was the highest in these regions, peaking at around 3,500 guilders in 1920.

In the sandy provinces (Overijssel, Gelderland, Noord-Brabant, and Limburg) farming was often mixed, less specialized and market-oriented, and small-scaled. By 1904 these farmers were still reluctant to apply artificial fertilizers on a large scale. In the following decades, however, the total purchase of artificial fertilizers in these provinces increased continuously, even when the growth in the other regions stagnated or declined, as was the case between 1913 and 1920. Whereas between 1904 and 1924 the total tons purchased quadrupled, the guilders spent per 100 hectares increased nearly six-fold. In 1904 only $39 \%$ of the cooperatively purchased artificial fertilizers in the Netherlands were applied in the mixed provinces, but twenty years later this had increased to $53 \%$. Although the figures in Graph 4.3 have their shortcomings - no insight is given in non-cooperative fertilizer trade or in the substantial regional variation within provinces - they clearly show a general trend: once lagging behind, the inland mixed provinces gradually decreased the gap with the arable regions and caused total Dutch artificial fertilizer usage to increase to unprecedented levels.

The rapid increase in Dutch artificial fertilizer usage in the early twentieth century is a story of small farmers following the path taken by larger farmers. The small farmers profited from the pioneering done by others: they followed after infrastructure had developed, after prices had dropped, after quality had improved, and after market problems had been solved through supply cooperatives. Familiarity with artificial fertilizers continuously increased as knowledge became more easily accessible. The staggering increase in Dutch artificial fertilizer usage, then, can also be attributed to an improved exchange and diffusion of knowledge. 


\subsection{Diffusing knowledge on artificial fertilizers}

The introduction of artificial fertilizers and other imported inputs created challenges. Dutch individual farmers could by themselves not keep up with the role and nature of knowledge in farming changing radically. One of the things done by the Dutch government, Chapter 3 has shown, was to unfold a network of agricultural experiment stations. After the first agricultural experiment station opened in Wageningen in 1877 , by 1900 there were six agricultural experiment stations conducting chemical tests with fertilizers and issuing quality marks. This system was reformed in 1915, when the agricultural experiment station in Maastricht became the country's centre for control of fertilizers and feedstuffs and the other experiment stations could focus on other issues. Since 1926 one of the departments of the experiment station in Groningen focused on soil fertility and became the independent Institute for Soil Science. ${ }^{14}$

The knowledge generated by these institutes was diffused among the Dutch farming population by public agricultural consultants particularly. Educated in agronomy, these agricultural consultants had the ability to transform theoretical knowledge into applicable knowledge. With their expertise on the required nutrients of crops and the chemical formation of different soils, the public agricultural consultants were well equipped to advise farming communities on artificial fertilizers.

While public agricultural consultancy was an important channel to diffuse knowledge on artificial fertilizers, other channels were less fit to do so. Supply cooperatives, to start with, gave farmers access to fertilizers against low prices, but it is unclear to what extent they could convert chemical knowledge into applicable knowledge of fertilizing. The supply cooperatives were organized and run by farmers themselves, who lacked chemical training. The supply

\footnotetext{
${ }^{14}$ D.J. Maltha, Honderd jaar landbouwkundig onderzoek in Nederland 1876-1976 (Wageningen: Centrum voor landbouwpublikaties en landbouwdocumentatie, 1976), 105-7. Harro Maat, "Het innovatiesysteem voor de Nederlandse landbouw," NEHA-Jaarboek voor economische, bedrijfs- en techniekgeschiedenis, 66 (2003): 245. K. Harmsen, Het Instituut voor Bodemvruchtbaarheid 1890-1990 (Haren: Instituut voor Bodemvruchtbaarheid, 1990).
} 
cooperatives also did not have the resources to employ educated advisors. The Centraal Bureau employed one academically-trained consultant from 1906 to 1925 and a second one from 1911 to 1922 . These two 'propagandists' advised the member supply cooperatives and managed experimental fields, which were usually financed by companies from which the Centraal Bureau ordered their fertilizers. The Centraal Bureau stopped organizing their own consultancy after 1925, when the expansion of public agricultural consultancy had made it redundant. ${ }^{15}$ Because its consultancy work was small-scaled and directed towards advertising ('propaganda'), the role of the Centraal Bureau as diffuser of knowledge on artificial fertilizers was probably limited.

Another channel through which applicable knowledge on artificial fertilizers could be diffused was the fertilizer industry itself. Because the Dutch fertilizer industry was still in its infancy during the early twentieth century, private consultancy was mainly done by agents representing foreign companies. The Kali-Syndikaat, for example, was a German cartel for potassium fertilizers that opened their 'Landbouwkundig Bureau' ('Agricultural Office') in Utrecht in 1904. Following the example set by equivalents in Germany, information agencies of foreign fertilizer companies gave lectures, handed out brochures, set up experimental fields, and published the results of the experimental fields in agricultural periodicals. In the 1930s Hoogovens and DSM largely followed this example, though they collaborated with Dutch research institutes, with Dutch public agricultural consultancy, and with the Centraal Bureau on a large scale. ${ }^{16}$ Although this might be due to a chauvinistic sentiment - Dutch companies, Dutch cooperatives, and Dutch consultants jointly diffusing Dutch artificial fertilizers - it could

\footnotetext{
${ }^{15}$ Also the work done by 'business advisors' (bedrijfsvoorlichters), occasionally hired by the Centraal Bureau to help the member supply cooperatives improve their businesses, was taken over by public agricultural consultants after the Second World War. J.H. van Stuijvenberg, Het Centraal Bureau. Een coöperatief krachtveld in de Nederlandse landbouw 1899-1949 (Rotterdam, 1949), 201-3.

${ }^{16}$ Homburg, Groeien door kunstmest. DSM Agro 1929-2004, 30-32, 86.
} 
also mean that public consultancy was more efficient, better organized, or more influential than the networks established by the private industry.

Private consultancy had at least three disadvantages. First, the private industry hired consultants to market their products. Discussing German private consultancy, Frank Uekötter argues that German farmers were often hesitant to follow the advices of salesmen, as these 'had a product to sell' ${ }^{17}$ Private consultants, in other words, were thought to lack objectivity. Second, private consultants were specialists in the specific fertilizers their company sold, but lacked an overview of the wide range of other fertilizer types that could also be applied: a consultant selling nitrogen fertilizers obviously had less to say about potassium. Second, private consultants were usually not specialized in one region or soil type, but served the entire Netherlands. As such, they lacked 'location-specific' knowledge of soil quality, water availability, and other variables pivotal to the successful application of artificial fertilizers. Although private consultancy certainly contributed to the exchange of knowledge, it was less influential than other channels.

Historical textbooks correctly emphasize the important role of public agricultural consultants in diffusing knowledge on fertilizers. This claim, however, is presented as a given and is not substantiated with much historical evidence. ${ }^{18}$ Important questions thus remain unanswered. How did Dutch agricultural consultants operate and how and to what extent did they contribute to the exchange of applicable knowledge? The following sections answer these questions and confirm the pivotal role of public agricultural consultants by analysing their work and by comparing the historical development of Dutch public agricultural consultancy with that of equivalents in Western Europe.

\footnotetext{
${ }^{17}$ Frank Uekötter, Die Wahrheit ist auf dem Feld. Eine Wissensgeschichte der deutschen Landwirtschaft, 3rd ed., Umwelt und Gesellschaft 1 (Göttingen: Vandenhoeck \& Ruprecht, 2012), 411.

${ }^{18}$ See for instance Knibbe, Agriculture in the Netherlands 1851-1950. Production and Institutional Change, 16162. Bieleman, Boeren in Nederland. Geschiedenis van de landbouw 1500-2000, 284. Van Zanden, De economische ontwikkeling van de Nederlandse landbouw in de negentiende eeuw, 1800-1914, 262.
} 


\subsection{Dutch public agricultural consultancy, c. 1890-1960}

The first agricultural consultants in nineteenth-century Europe were employed in Germany, where agricultural societies hired agronomists to give lectures and to advise farmers. Since the early 1870s a few Dutch agricultural societies hired wandelleraren (based on the German term Wanderlehrer), who travelled around giving lectures. Because the title of wandelleraar was not protected and quality controls were lacking, the effectiveness and added value of these consultants has been questioned. During the Agrarian Depression, the State Committee on Agriculture, established in 1886 to investigate how the Dutch government could intervene (see Chapter 3), argued for state-led agricultural consultancy. The first Rijkslandbouwleraar (literally State Agricultural Teacher), a title later changed to Rijkslandbouwconsulent (State Agricultural Consultant), was installed for the provinces Gelderland and Overijssel in 1890, and soon followed elsewhere. These consultants, who were required a degree in agronomy from the State Agricultural College in Wageningen or from a foreign agricultural college, were at first assigned to provinces, but later to districts of a smaller geographical size. Within these assigned districts they were to give free advices, to give advisory lectures, to organize experimental fields, to set up education, and to train teachers in agronomy. ${ }^{19}$

Dutch public agricultural consultancy expanded considerably after the 1890 s. While the range of tasks of the consultants initially concentrated around proper consultancy work (i.e. advising, lecturing, and teaching), by the early 1900s the consultants had more tasks, such as writing annual reports and providing data for national agricultural statistics. In 1938 a meeting of consultants recalled that those assigned during the 1890s could not keep up with the widening range of responsibilities. Technological advancements had resulted in an increasing complexity of issues on which advice was asked for' ${ }^{20}$ The consultants assigned since the

\footnotetext{
19 P.J.P. Zuurbier, "De besturing en organisatie van de Landbouwvoorlichtingsdienst" (Landbouwhogeschool Wageningen, 1984), 30-32.

20 'Aanvankelijk had men een Rijkslandbouwleeraar per provincie, die voorlichting had te verschaffen over alles, wat verband houdt met het landbouwbedrijf. Deze vorm van voorlichting was voor de landbouwers de
} 
1890s, which had initially advised on virtually any topic (hence sometimes called 'general' consultants), now started concentrating on issues related to arable farming specifically. Other consultants were employed to focus on livestock farming, horticulture, and even on more specific topics, such as beekeeping and poultry. By 1935, there were 59 public agricultural consultants in total: 24 'general' consultants, 18 horticultural consultants, 12 livestock consultants, three poultry consultants, and two beekeeping consultants. ${ }^{21}$

The Great Depression of the 1930s was yet another stimulus for the expansion of public agricultural consultancy. Up to that point, consultancy had been rather straightforward. The insatiable food demand - domestic or foreign - led to an increase in Dutch farmers' net income through an increase in production, so consultants could concentrate on agronomic issues hindering yield increase. ${ }^{22}$ This focus shifted after the Depression. ${ }^{23}$ Rather than dealing with agronomic problems, consultants now had to advise on production costs, mortgages, and rents, even though most consultants lacked an overview of the financial profitability of farms in their districts. ${ }^{24}$ In the late 1930 s the Dutch government installed six business consultants,

eenvoudigste en gemakkelijkste, daar ze met al hun moeilijkheden, het bedrijf betreffende, terecht konden bij één persoon. Toen echter de voorlichting steeds meer in omvang toenam, kon dit eenvoudige systeem niet worden gehandhaafd. [...] De gang van zaken leidde, vooral ook in verband met het steeds gecompliceerder worden der vraagstukken, waaromtrent voorlichting werd verzocht, in de richting van de specialisatie.' NA, 2.11.01, Directie van de Landbouw: Afdeling Akker- en Weidebouw, 1898-1962, inv. nr. 198, Vergaderingen Rijkslandbouwconsulenten, minutes of a meeting on July 29, 1938, page 1.

${ }_{21}$ NA, 2.11.01, Directie van de Landbouw: Afdeling Akker- en Weidebouw, 1898-1962, inv. nr. 173, Landbouwconsulenten algemeen.

22 'Voor het optreden van de wereldcrisis, doorleefde de Nederlandsche Landbouw een tijdperk van bloei en vooruitgang [...] het prijspeil was meestal zoo ruim tegenover de productiekosten afgestemd, dat een vergrooting der bruto-opbrengst vrijwel altijd een stijging der netto-opbrengst beteekende. Dit hield in, dat men er maar lustig op los kon produceeren om aan het eind van zijn boekjaar zijn ijverig streven meestal met klinkende munt te zien beloond. [...] dit streven naar verhoogde productie was het eenige embleem, dat de voorlichtingsdienst in zijn banier had, doch het is wél waar en alleszins ook begrijpelijk, dat men ook in dien kring de vergrooting van het netto-overschot gaarne zocht in een verhooging van de bruto-opbrengst.' NA, 2.11.01, Directie van de Landbouw: Afdeling Akker- en Weidebouw, 1898-1962, inv. nr. 198, Vergaderingen Rijkslandbouwconsulenten, minutes of a meeting on July 29,1938 , page 8 .

23 'Toen de crisis op ontstellend snelle wijze om zich heen greep, werden producenten zoowel als voorlichters er op gevoelige wijze aan herinnerd, dat er nog zoo iets bestond als een wet der verminderende meeropbrengsten.' NA, 2.11.01, Directie van de Landbouw: Afdeling Akker- en Weidebouw, 1898-1962, inv. nr. 198, Vergaderingen Rijkslandbouwconsulenten, minutes of a meeting on July 29, 1938, page 8.

24 'Aanvankelijk had men een Consulent voor het geheele bedrijf, maar vorderingen in de wetenschap maakten dat geen enkel mensch het bedrijf in zijn geheel onder de knie kon hebben, en kregen we geleidelijk de specialisten als landbouw-, tuinbouw-, veeteelt- en zuivelconsulenten. Aan de specialisatie is uiteraard het bezwaar verbonden van het geheel niet voldoende te overzien, vandaar de Bedrijfsconsulent die deze onderdeelen tot een harmonisch geheel moet trachten te combineeren, omdat het op de totaal uitkomst aankomt.' NA, 2.11.0.1, Directie van de 
economists who were to advise specifically on financial and economic issues. ${ }^{25}$ The government also installed extra specialized consultants who advised the other consultants about specific topics, such as mechanization, refrigeration, and plant breeding. In addition, assistants were hired to help the consultants in their day-to-day business. ${ }^{26}$ These assistants, 65 in total, were assigned to regional units within the consultants' districts and represented the consultants by conducting soil surveys, collecting data, maintaining experimental fields, and keeping in close contact with farmer communities. ${ }^{27}$

The growth and specialization of Dutch public agricultural consultancy since 1900 had resulted in fragmentation. Without an overarching masterplan, individual consultants had a considerable degree of freedom. The Depression of the 1930s, though, caused public agricultural consultancy to be more directed at small farmers in particular. The Dienst voor Kleine Boeren (Small Farmers' Service), a state fund set up in 1937 to aid small farmers impoverished during the Depression, financed the growth in personnel. The consultants and their assistants were to 'rationalize' small farming. The Directory of Agriculture understood 'rationalization' as the optimum combination of the following parameters: (1) absolute increase in production (2) absolute decrease of inputs (3) producing goods of a higher value without increasing production costs (4) using cheaper inputs without decreasing absolute production. ${ }^{28}$

Landbouw: Afdeling Akker- en Weidebouw, 1898-1962, inv. nr. 173, Landbouwconsulenten algemeen, minutes of the meeting of public agricultural consultants in Noord-Holland on Augustus 6, 1936, page 1.

${ }^{25}$ NA, 2.11.01, Directie van de Landbouw: Afdeling Akker- en Weidebouw, 1898-1962, inv. nr. 173, Landbouwconsulenten algemeen, minutes of the meeting of the agricultural consultants of Groningen on November 24, 1936.

26 'Er werd uiteengezet, dat tot dusverre de assistenten voor het allergrootste gedeelte werkzaam waren voor den Bedrijfsconsulent. Zij waren door dezen aangesteld en met werkzaamheden door dezen belast. Zoo nu en dan werden in overleg ten behoeve van den Rijksveeteelconsulent, den Cultuurconsulent en den Rijkslandbouwconsulent in een naburig gebied werkzaamheden verricht. [Het] werd vastgesteld, dat de assistenten mede in de eerste plaats beschikbaar zouden zijn voor de uitvoering van objecten, die door het College als nuttig en noodzakelijk werd geacht, terwijl een verrichten van werkzaamheden ten behoeve van de afzonderlijke leden van het College in overleg met den Bedrijfsconsulent plaats zou kunnen vinden.' NA, 2.11.01, Directie van de Landbouw: Afdeling Akker- en Weidebouw, 1898-1962, inv. nr. 173, Landbouwconsulenten algemeen, minutes of the meeting of the agricultural consultants of Groningen on November 24, 1936, page 2

${ }^{27}$ The number of 65 assistants is based on a 1937 list found in the archival records of the Directory of Agriculture: NA, 2.11.01, Directie van de Landbouw: Afdeling Akker- en Weidebouw, 1898-1962, inv. nr. 197, Vergadering Rijkslandbouwconsulenten 1937.

${ }_{28}$ A.W.G. Koppejan, 'Doel en werkwijze der economische bedrijfsvoorlichting in den landbouw', Maandblad voor den Landbouwvoorlichtingsdienst, 1 (October 1944), 383-394. 
Aiming to bring this ideal of 'rationalized farming' into practice, public agricultural consultancy further expanded after the Second World War. In 1947 the country was divided into 23 districts, each with their own consultant, while the government also installed eighteen specialized consultants, 40 deputy consultants, 160 head assistants, and no less than 600 assistants, approximately one assistant per 350 farms. Links with research institutes and experiment stations were tightened and 'vertical' consultancy, from consultant to farmer, was accompanied by 'horizontal' consultancy, which referred to farmers advising each other in 'organizations for business consultancy'. These organizations resulted in an emphasis on group consultancy at the expense of individual consultancy, which was far less efficient. Lastly, consultants and their assistants regularly had to follow training courses to better keep up with scientific and technological advancements. ${ }^{29}$ Since the 1930s, in sum, Dutch public agricultural consultancy professionalized and expanded continuously, reaching its peak around the 1960s. Hereafter it was partly privatized or handed over to research institutes. ${ }^{30}$

It would be misleading to confine the added value of Dutch public agricultural consultancy to the communication between farmers and consultants. Besides providing expert knowledge, Dutch public agricultural consultancy established platforms that facilitated communication among farmers themselves. Farmers exchanged information at societies or cooperatives set up with consultants' advice, through periodicals established on the initiative of consultants, or at public lectures. The most far-reaching component of Dutch public agricultural consultancy, however, was arguably the education it organized. Between 1900 and 1940 the number of winter courses, at which students received training during two or three

\footnotetext{
${ }^{29}$ Koppejan, 'Doel en werkwijze der economische bedrijfsvoorlichting in den landbouw'; S.W. Meurs, 'Verenigingen voor Bedrijfsvoorlichting', Maandblad voor den Landbouwvoorlichtingsdienst 4 (1947), 108-112; L.H.M. Hartmans, 'De wezenlijke grondbeginselen van een doeltreffende bedrijfsvoorlichting', Maandblad voor den Landbouwvoorlichtingsdienst 10:10 (Oktober 1953), 369-376; J.H. Brinkgreven, 'Over de methodiek van de landbouwvoorlichting’, Maandblad voor den Landbouwvoorlichtingsdienst 10 (1953), 466-471; J.M.A. Penders, 'Rondom de landbouwvoorlichting III', Maandblad voor den Landbouwvoorlichtingsdienst 11:9 (September 1954), 405-407.

${ }^{30}$ P.J.P. Zuurbier, De relaties tussen onderzoek, voorlichting en de boer (Den Haag: Directie Bedrijfsstructurele Aangelegenheden, 1978), 6. Zuurbier, "De besturing en organisatie van de Landbouwvoorlichtingsdienst," 55.
} 
evenings a week, increased from 130 to 1,703 , whereas the number of agricultural schools increased from 7 to 104 . Through this education, farmers became acquainted with the basic principles of the natural sciences and were trained in plant diseases, fertilizing, and cattle fodder. This system increased the level of education of the Dutch farming population considerably: while by 1900 educated farmers were very scarce, by the 1950 s nearly half of the Dutch farming population had received some form of agricultural education. ${ }^{31}$ With the expansion of Dutch public agricultural consultancy, informal knowledge networks and intergenerational training were supplemented - though certainly not replaced - by new knowledge channels and formal education, making Dutch farmers better equipped for the rapid knowledge intensification following the large usage of artificial fertilizers.

\subsection{Dutch public agricultural consultancy in international perspective}

In retrospect, the development of Dutch public agricultural consultancy can best be summarized as a two-fold specialization. This specialization was first and foremost geographical. While in the 1890 s every Dutch province had merely one consultant, after 1900 the consultants were assigned to smaller districts. By the 1930s these districts themselves were divided into smaller units which were assigned to assistants. This geographical specialization enabled more careful attention to the location-specific character of farming.

The specialization of Dutch public agricultural consultancy was also content-driven. After 1900 the Dutch government hired consultants specialized in livestock farming and horticulture, later followed by other experts who, the more specific their expertise became, operated nation-wide and advised the region-based consultants. As such, knowledge could be

\footnotetext{
31 The number of winter courses and agricultural schools come from A.W. van den Ban, Boer en landbouwonderwijs. De landbouwkundige ontwikkeling van de Nederlandse boeren, Bulletin Afdeling Sociologie en Sociografie van de Landbouwhogeschool 8 (Wageningen: Afdeling Sociologie en Sociografie van de Landbouwhogeschool, 1957), 7. The percentages of Dutch farmers having received agricultural education come from A.W. van den Ban, "Hoeveel boeren hebben landbouwonderwijs gevolgd?," Landbouwvoorlichting, June 1956, 314-17.
} 
passed on from the more specialized consultant, who kept up-to-date with the newest inventions and the latest insights and breakthroughs, to the region-based consultants, who adapted the new innovations and knowledge to the specific local circumstances of their district.

How does the organization of Dutch agricultural consultancy compare to agricultural consultancy elsewhere in Western Europe? In Germany, to begin with, the government became involved with agricultural consultancy during the last two decades of the nineteenth century, as was the case in the Netherlands. While the Dutch government gained nearly full control over agricultural consultancy, German public agricultural consultancy remained in strong competition with private consultancy. Besides the private industry (mainly seed and fertilizer companies), also agricultural societies, colleges, and research institutes were active in consultancy, making German agricultural consultancy a cacophony of different views. What is more, the German public agricultural consultants were usually connected to winter schools and thus had to confine their consulting work to the summer months. ${ }^{32}$

More structure was given to German public agricultural consultancy after the Second World War only. Agricultural consultancy became a tool in the government's hands to improve the nation's food security and to lift the German farming population out of poverty. By the late 1950s, Western Germany had 2,980 agricultural consultants, of whom 1,483 were connected to an agricultural school (thus combining consulting with educational duties) and 1,497 could fully concentrate on consultancy. This meant that there was on average one consultant per 445 farms (with more than two hectares). ${ }^{33}$

\footnotetext{
32 This in contrast to the Dutch public agricultural consultants. Although they were officially responsible for agricultural education in their assigned districts, the actual teaching was done by teachers and not, as in Germany, by the consultants themselves. In fact, the reform of Dutch public agricultural consultancy after the Second World War disconnected education and consultancy: the Dutch public agricultural consultants nog longer had agricultural education as one of their mission statements.

${ }^{33}$ Uekötter, Die Wahrheit ist auf dem Feld. Eine Wissensgeschichte der deutschen Landwirtschaft, 72-78, 334, 411.
} 
British agricultural consultancy followed a different development path, as it for long fully remained in private hands. ${ }^{34}$ The Royal Agricultural Society of England (RASE) hired consultants as early as the 1840s. These consultants were hired to solve the problems the members of RASE, mostly large estate owners, were confronted with. ${ }^{35}$ The consultants were not assigned to specific regions, but had to cover the entire country. Because RASE saw its membership decline and because its consultants addressed issues relevant to estate holders rather than smaller farmers, their actual impact was small. ${ }^{36}$ British public agricultural consultancy was only set up on a small scale since the 1910s. In 1914 the Board of Agriculture established eleven consultancy centres, attached to universities. With a small staff and few resources, the influence of these consultancy centres was limited. ${ }^{37}$ The consultancy centre for Yorkshire, for example, was connected to the University of Leeds and consisted of seven consultants, who had 20,000 farm holdings (not including holdings smaller than twenty acres) in their district, which means that there were at least 2,858 farm holdings per consultant. ${ }^{38}$ Although this number might have been lower elsewhere, the general picture is clear: British agricultural consultancy was underdeveloped compared to equivalents elsewhere.

The development of agricultural consultancy in Belgium, by contrast, closely resembled its Dutch counterpart. After the government installed nine consultants in the 1890s, specialization took place, with dairy consultants installed in 1896 , horticultural consultants in 1909, and livestock and business consultants shortly after the First World War. ${ }^{39}$ The total number of public agricultural consultants increased from 9 in 1885 to 30 in 1914, which

\footnotetext{
${ }^{34}$ The following mainly concerns England and Wales.

${ }^{35}$ Nicholas Goddard, Harvests of Change. The Royal Agricultural Soceity of England 1838-1988 (London: Quiller Press, 1988), 94-104.

${ }^{36}$ E.J.T. Collins, ed., 1850-1914, The Agrarian History of England and Wales 7 (Cambridge: Cambridge University Press, 2000), 609-10, 657-59.

${ }^{37}$ The eleven consultancy centres were in Newcastle, Manchester, Leeds, Nottingham, Aberystwyth, Bangor, Bristol, Reading, Cambridge, Wye, and Exeter.

${ }^{38}$ Edith H. Whetham, ed., 1914-1939, The Agrarian History of England and Wales 8 (Cambridge: Cambridge University Press, 1978), 66-67., 282-283, citation from 282.

${ }^{39}$ Yves Segers and Leen Van Molle, Leven van het land. Boeren in België 1750-2000 (Leuven: Davidsfonds, 2004), 91.
} 
corresponds to a growth of one consultant per 85,000 farmers in 1896 to one consultant per 15,000 farmers in $1910 .{ }^{40}$ In the following decades the number of farmers per consultant further decreased to 2,700 farmers per consultant in 1952 and to 1,000 farmers per consultant in the 1980s. Apart from this increase in personnel, agricultural consultancy was also expanded by conveying consultancy tasks to the various specialized experiment stations (concentrating on, for instance, floriculture or vegetable growth) that were established after the Second World War. $^{41}$

The international comparison above shows that Dutch public agricultural consultancy was among the most expanded and well-organized in Western Europe. The network of consultants improved the infrastructure through which knowledge was exchanged. It is important to note that the added value of Dutch public agricultural consultancy was not confined to the direct communication between farmers and consultants. The work of the consultants caused various spillover effects. Farmers could exchange information with each other at the public lectures of the consultants, through the periodicals established on the consultants' initiatives, and at the experimental fields administered by the consultants. The most far-reaching and influential component of public agricultural consultancy on the long-term was arguably the education consultants had to set up. Through winter schools, generations of Dutch farmers' sons got acquainted (or, one could argue, almost indoctrinated) with 'rationalized' farming, receiving education in for instance accounting, plant breeding, soil chemistry, and fertilization. With the expansion of Dutch public agricultural consultancy, informal knowledge networks and intergenerational training were supplemented - though certainly not replaced - by other knowledge networks and more formal forms of education. Through public agricultural

\footnotetext{
${ }^{40}$ Leen Van Molle, 100 jaar Ministerie van Landbouw. Het Belgisch landbouwbeleid in de wisselwerking tussen economische en sociale toestanden, politiek en administratie 1884-1984, Agricontact, koerier van het Ministerie van Landbouw, 154 (September 1984): 32.

${ }^{41}$ Segers and Van Molle, Leven van het land. Boeren in België 1750-2000, 160-61.
} 
consultancy, Dutch arable farming was better equipped for the rapid knowledge intensification it experienced.

\subsection{J. Elema, State Agricultural Consultant of Drenthe}

To show how public agricultural consultancy functioned in practice, this section focusses, as a ‘working example', on one single consultant. During his four decade long tenure (1895 to 1936) as the State Agricultural Consultant for the province of Drenthe, Jakob Elema kept detailed records, which give a clear insight into his daily activities. By following his work over the years, insight is given into the relationship between (small) farmers and consultants and the otherwise rather abstract exchange of knowledge is made somewhat more tangible.

Born in 1872, Jakob Elema, the son of a Groningen farmer, became the assistant to the consultant for Noord-Brabant shortly after graduating in agronomy in 1894. Elema's provision of services to the many small farmers in Noord-Brabant was met with much satisfaction: because he had the ability to be 'plain' in 'speaking, appearance, and acting' and was able to conform to the 'mores and manners' of the small farmer, Elema earned a reassignment to Drenthe, where he became the province's sole consultant in 1895 , merely 22 years old. ${ }^{42}$ First advising on any topic, Elema later concentrated on fertilizing, soil condition, and arable farming, as other tasks were transferred to a dairy consultant (appointed in 1913) and a livestock consultant (appointed in 1918). ${ }^{43}$ Elema's growing authority on fertilizing and soil chemistry resulted in the (part time) position of distinguished professor at the State Agricultural College in Wageningen in 1918. He usually stayed in Wageningen a couple of weeks per year to teach courses in soil improvement. ${ }^{44}$

\footnotetext{
${ }^{42}$ A. Vedder, "Prof. Ir. Jacob Elema," Nieuwe Drentse Volksalmanak, 75 (1957): 10.

${ }^{43}$ Drents Archief (hereafter DA), 0154 Rijkslandbouwleraar/Rijkslandbouwconsulent voor Drenthe (hereafter RvD), inv. nr. 22, Ingekomen stukken en kopieën van verzonden stukken 1918, letter from December 12, 1918.

${ }^{44}$ DA, RvD, inv. nr. 22, Ingekomen stukken en kopieën van verzonden stukken 1918, correspondence with the State Agricultural College in Wageningen in February 1918.
} 
When Elema first arrived in Drenthe in 1895, the province was the least populated, industrialized, and urbanized of all the Dutch provinces. The male labour population active in agriculture, though decreasing since the mid-nineteenth century, remained relatively high at $48.3 \%$ in 1920 , well above the national average. ${ }^{45}$ The bulk of these farmers were small: whereas the number of farmers with more than 20 hectares of land decreased in absolute and relative terms, the share of farmers with merely 1 to 5 hectares - the smallest property class in the 1910 census - had increased to $51.9 \% .{ }^{46}$ For long these small farmers had been largely cut off from urban markets and had conducted mixed subsistence farming. Since the late nineteenth century significant improvements in infrastructure and the growth of the food processing industry, in particular potato starch factories, caused Drenthe's farmers to produce for urban markets. ${ }^{47}$ Elema's tenure in Drenthe, then, coincided with its agricultural sector modernizing and integrating into expanding domestic and foreign markets.

Elema's arrival in Drenthe in 1895 was not met without scepticism. Looking back two decades later, an agricultural society noted that Elema had to deal with 'outdated ideas', with 'a desire for preservation', and with 'village despots hindering the efforts of the 22-year old'. ${ }^{48}$ In 1895 he had received merely 34 letters from farmers, while his stand at the weekly farmers' market in the town of Hoogeveen, set up to promote his work and to increase his visibility, was only visited by 75 farmers in 1898 - on average 1.43 farmers weekly, not a particularly high number. ${ }^{49}$ Also giving advisory lectures was not easily done. Because local agricultural societies were still rare, Elema could not be hosted by an organization. As local newspapers or

\footnotetext{
${ }^{45}$ P.Th.F.M. Boekholt, "De nieuwste tijd 1850-1945," in Geschiedenis van Drenthe, ed. J. Heringa et al., 2nd ed. (Meppel: Boom, 1986), 611-12.

${ }^{46}$ The 1910 census reveals that there were also 4,141 agricultural labourers who owned less than 1 hectare. These labourers ran their own farms while simultaneously having to perform wage labour for larger farmers to survive. See J. Bieleman, Boeren op het Drentse zand, 1600-1910. Een nieuwe visie op de "oude" landbouw, AAG Bijdragen 29 (Wageningen, 1987), 542-47.

47 J. Bieleman, "De landbouw in de periode 1850-1945," in Geschiedenis van Drenthe, ed. J. Heringa et al., 2nd ed. (Meppel: Boom, 1986), 547-90.

${ }^{48}$ Quotes from Boekholt, "De nieuwste tijd 1850-1945," 624-25.

${ }^{49}$ Drents Archief, 0154 Rijkslandbouwleraar/Rijkslandbouwconsulent voor Drenthe (hereafter DA, RvD), inv. nr. 30, Jaarverslagen 1895-1914, 'Verslag van den Rijkslandbouwleeraar voor Drenthe van het jaar 1895'.
} 
agricultural periodicals, which could have pre-announced his lectures, were still largely absent, Elema often had to initiate his visits to villages himself, contacting mayors, local church leaders, and school masters to organize meetings with the local farming community and to spread the word of his coming. Moreover, without local newspapers and agricultural periodicals he could not publish the content of his lectures, as was done by other agricultural consultants elsewhere. ${ }^{50}$ In sum, channels through which knowledge could be exchanged were still largely lacking.

Elema's work improved knowledge exchange and established platforms at which discussion and communication could take place. Besides his weekly visits to the Hoogeveen market, since the early 1900s Elema also organized a weekly consultation hour at his home in the town of Assen. More importantly, in 1917 he helped set up the Drents Landbouwblad, the province's main agricultural periodical. This journal published his answers to questions that farmers submitted into the journal's 'question box', presumably one or more actual boxes found at market places, pubs, or other public places. ${ }^{51}$ The Drents Landbouwblad also published the results of Elema's experimental fields. Although some of these were used to test crop varieties, most of them concerned fertilizers, the bottleneck of farming in Drenthe. Some experimental fields tested different kind of artificial fertilizers on various soil types, others functioned as 'demonstration fields' to visually show and convince farmers, visiting or passing by coincidentally (the fields had to have, Elema dictated, 'a favourable location close to a public road with as much traffic as possible') of the positive results artificial fertilizers had. ${ }^{52}$ Although the actual impact of the experimental fields cannot be quantitatively assessed - the number of farmers visiting the fields are not documented - the fact that the experimental fields remained a major part of Elema's work is proof of their believed effectiveness as communication tools.

\footnotetext{
${ }^{50}$ DA, RvD, inv. nr. 30, Jaarverslagen, 1895-1914, 'Verslag van den landbouwlezingen in Drenthe gedurende den Winter 1896-1897'.

${ }^{51}$ DA, RvD, inv. nr. 30, Jaarverslagen 1895-1914, 'Verslag van de Rijkslandbouwleeraar voor Drenthe van het jaar 1900'.

52 DA, RvD, inv. nr. 28, Ingekomen stukken en kopieën van verzonden stukken 1931-1933, 'Overzicht van de antwoorden der landbouwconsulenten op de circulaire dd 9 september 1932 van den Inspecteur van den Landbouw' and 'Overzicht van de onderwerpen, waarvoor de consulenten veldonderzoek wenschelijk achten'.
} 
Another channel which Elema established were his public lectures. These lectures were usually given in local pubs, churches, or schools, often after dinner time, and rarely during the summer months. In the 1890s and 1900s Elema held more than twenty lectures annually, but after parts of his tasks were transferred to other consultants he reduced his lectures to between ten and twenty per year. Although it could vary - in some instances, Elema noted, bad weather or the poor condition of roads reduced participation - average attendance increase from about 50 farmers per evening in the 1890 s to around 70 per evening in the $1920 \mathrm{~s}$ and $1930 \mathrm{~s} .{ }^{53}$ The topics Elema lecture on were, ofcourse, not randomly picked. His lectures had two main aims. First, he wanted to increase interest in a more 'progressive' way of farming, as Elema called it. In the 1890s and early 1900s, Elema scribbled his perception of his audiences in one of his notebooks. While some groups of listeners were 'distrustful', 'underdeveloped', 'conservative', or simply had a 'wrong spirit', other audiences, Elema noted contently, were 'developed', 'woke up', were 'ambitious', and 'started to accept new ideas'. ${ }^{54}$

The second aim of Elema's lectures was to familiarize farmers with 'rational fertilizing'. Other topics, he thought, deserved attention only after farmers had learned how to maintain or increase the fertility of their fields. ${ }^{55}$ Fertilization was indeed the most discussed topic, while also most questions during the Q\&A sessions after the lectures revolved around fertilizing (some public lectures did not even center around one specific topic at all, but simply had 'questions and answers' on the agenda), and during some lectures the audience was not

\footnotetext{
${ }^{53}$ DA, RvD, inv. nr. 44, 45, and 46, Boekje en schriftjes met overzichten van door J. Elema gehouden landbouwlezingen, 1896-1937.

${ }^{54} \mathrm{DA}, \mathrm{RvD}$, inv. nr. 44, Boekje en schriftjes met overzichten van door J. Elema gehouden landbouwlezingen, 1896-1937. The notebook is entitled "Lijst van landbouwlezingen in Drenthe".

55 "Als grond bij het kiezen der onderwerpen voor de lezingen is genomen, dat getracht moet worden - vooral op de zandstreken geldt dit - in de eerste plaats de landbouwers meer en meer op de hoogte te brengen met eene rationeele bemesting en bewerking hunner gronden. Eerst dan wordt een vaste grondslag verkregen voor een betere veevoedering en daarna komen de maatregelen ter verbetering van het vee tot meer volledig resultaat.' DA, RvD, inv. nr. 30, Jaarverslagen 1895-1914, 'Verslag van de werkzaamheden in 1898 van de Rijkslandbouwleeraar voor Drenthe'.
} 
interested in any other topic but artificial fertilizers. ${ }^{56}$ Elema's lectures on artificial fertilizers were organized in such a way that Elema could concentrate on subtopics depending on the local 'characteristics of the soil and the farm' and the 'needs of the region', while sometimes he had to clarify issues introduced earlier or he had to answer questions that had come up since he last spoke in the village. ${ }^{57}$ These questions and discussions were very valuable, Elema noted, as they brought him in direct contact with individual farmers and granted a quick insight into their problems. ${ }^{58}$ The topics of his lectures make clear that Elema was indeed responsive to the issues farmers dealt with. In 1915 and 1917, for instance, he lectured about the scarcity of fertilizers caused by the First World War, while from 1933 to 1935, during the peak of the Great Depression, four lectures were entitled 'crisis fertilizing'. ${ }^{59}$ It seems that, over time, Elema's lectures became more detailed and complex. Whereas his early lectures were about fertilizing in general - the need to keep his lectures understandable narrowed down the number of topics and caused the lectures to be, in his own perception, somewhat superficial - since the 1920s the

\footnotetext{
${ }^{56} \mathrm{DA}, \mathrm{RvD}$, inv. nr. 44, Boekje en schriftjes met overzichten van door J. Elema gehouden landbouwlezingen, 1896-1937, "Lijst van landbouwlezingen in Drenthe".

57 'De lezingen over bemesting, een zeer geliefkoosd onderwerp voor de landbouwers, regelden zich natuurlijk naar den aard van den bodem en het bedrijf. Naar de behoefte van de streek en met het oog op de zaken vroeger op de lezingen in dezelfde plaats behandeld, werden verschillende hoofdpunten meer uitvoerig besproken als groenbemesting, kalkaanwending, resultaten van proefvelden, enz. DA, RvD, inv. nr. 9, Ingekomen stukken en kopieën van verzonden stukken 1898, 'Verslag van de Landbouwlezingen gehouden in den winter 1897/98 door den Rijkslandbouwleeraar voor Drenthe', 1.

$58 \mathrm{Na}$ iedere lezing werden gelegenheid gegeven tot het doen van vragen, waarvan meestal, wanneer maar eerst één is begonnen of op den weg geholpen, druk gebruikt wordt gemaakt. Volgens onze meening is dit z.g. debat het voornaamste nut, dat eene lezing sticht. Ieder heeft gelegenheid vragen te doen direct uit zijn eigen practijk; tegelijk heeft men daardoor gelegenheid vroeger vertelde zaken nog eens weer uit te leggen.' Some meetings with farmers did not even center around one specific topic at all, but simply had 'questions and answers' on the agenda: 'In één geval n.l. te Kloosterveen werd zelfs de geheele avond besteed met "vragen en antwoorden", hetgeen schijnbaar goed voldeed. Dit kan echter alleen op die plaatsen waar ontwikkelde landbouwers wonen die in de praktijk reeds ervaringen met de nieuwe hulpmiddelen in het landbouwbedrijf hebben opgedaan'. DA, RvD, inv. nr. 9, Ingekomen stukken en kopieën van verzonden stukken 1898, 'Verslag van de Landbouwlezingen gehouden in den winter 1897/98 door den Rijkslandbouwleeraar voor Drenthe', 1. 'Hoewel over het directe nut dier lezingen verschillend geoordeeld kan worden, meent ondergeteekende dat ze noodig zijn om in persoonlijke aanraking met de landbouwers te blijven; vele adviesaanvragen zijn er het gevolg van.' DA, RvD, inv. nr. 30, Jaarverslagen 18951914, 'Verslag van de werkzaamheden van den Rijkslandbouwleraar voor Drenthe over het jaar 1902', 1.

${ }^{59}$ DA, RvD, inv. nr. 31, Jaarverslagen 1915-1925, inv. nr. 32, Jaarverslagen 1926-1936.
} 
lectures became more specific, focusing in more detail on topics such as nitrogen, phosphorus, potassium, or chalk. ${ }^{60}$

The most effective platform for knowledge exchange that Elema set up was education. In the 1890s, agricultural education in Drenthe was nearly non-existent, consisting of a few winter courses with low numbers of students. At the winter course in the village of Beilen, for example, merely 10 students received classes from the local school master during two nights per week, from late October to early April. ${ }^{61}$ Without sufficient teachers, Elema complained, formal agricultural education could not be expanded and farmers' sons would continue to receive their training at home.$^{62}$ Rather than educating farmers' sons himself, Elema chose to spent all his working hours allocated to education on training school masters for the earliermentioned official teacher's qualification for agronomy (the Landbouwakte). ${ }^{63}$ Although these teachers were educated in various topics (dairy production, fodder, physics, botany), a substantial part of their class hours was spent on chemistry, fertilizing, and soil treatment. ${ }^{64}$ By making these teachers acquainted with these issues, Elema created a network of agents diffusing his ideas, methods, and convictions.

While agricultural education in Drenthe had been meagre in the 1890s, it expanded rapidly in the subsequent decades. By 1917, for instance, Elema oversaw 21 winter courses with 285 students jointly, 23 courses for adult farmers with 390 students, five courses for girls and women with 97 students, and one teachers' course with 10 students. ${ }^{65}$ He successfully

\footnotetext{
${ }^{60}$ DA, RvD, inv. nr. 30, Jaarverslagen 1895-1914, 'Verslag van de werkzaamheden van den Rijkslandbouwleraar voor Drenthe over het jaar 1902', 1. Elema usually mentioned the topics he lectured on in his annual reports to his superiors.

${ }^{61} \mathrm{DA}$, RvD, inv. nr. 8, Correspondence 1896-1897, 'Verslag van den Wintercursus voor Onderwijs in landbouwkunde 1896-1897 te Beilen', 1.

${ }^{62}$ DA, RvD, inv. nr. 30, Jaarverslagen 1895-1914, Jaarverslag 1895, page 9.

${ }^{63}$ In his year reports Elema accounted for the way he spent his working hours.

${ }^{64}$ In 1915, for instance, 99 hours were spent on the course 'natural sciences' (which included physics, chemistry, and 'practical chemistry'), 30 hours were spent on dairy production, 30 hours on 'knowledge about soil', 30 hours on fertilizing, 12 hours on botany, and 39 hours on cattle breeding and cattle feed. DA, RvD, inv. nr. 21, Ingekomen stukken en kopieën van verzonden stukken 1914-1917, report on the teachers' course, 17 March 1915.

${ }^{65}$ DA, RvD, inv. nr. 21, Ingekomen stukken en kopieën van verzonden stukken 1914-1917, no. 581, Letter from 18 April 1917. Unfortunately not all of Elema's year reports on agricultural education in Drenthe have survived.
} 
lobbied for more state funding, which led to seven agricultural schools (established in 1907, $1917,1922,1928,1932$, and 1933) at which students followed classes during the day rather than, as with the winter courses, only during evenings. ${ }^{66}$ Once asked how Drenthe's agricultural sector could be made resilient for future challenges, Elema replied that farmers should send their children to agricultural schools, so that in the future 'the youth can profit from scientific discoveries'. ${ }^{67}$ Elema's emphasis on education seems to have been affirmed by the farming population of Drenthe. A survey in 1955, nearly twenty years after Elema's retirement, reveals that $34 \%$ of the Drenthe farmers above age 35 had followed agricultural education, while this percentage was $70 \%$ for farmers below age 35 . Although slightly below the national average, these figures are nevertheless telling of the rapid diffusion of agricultural education in Drenthe, particularly given that Elema established Drenthe's agricultural education from scratch and that these figures include agricultural labourers, who usually had a relatively low level of education. ${ }^{68}$

Through his personal ties Elema connected Drenthe with national or international networks. Elema's correspondence shows that he urged government officials to increase funding for consultancy and education and he pleaded with railway companies, local authorities, and other stakeholders to improve Drenthe's infrastructure. He consciously kept in contact with experts and knew when his expertise fell short, corresponding, among others, about plant diseases with the Plant Pathology Laboratory in Amsterdam and about crop varieties with

\footnotetext{
${ }^{66}$ After his retirement, more agricultural schools followed in 1937, 1941, 1945, 1947, 1948, 1949, and 1953, leading to a total of 25 agricultural schools. H. Dekker, Landbouwonderwijs in Drenthe. Kwantitatieve en $k$ walitatieve analyse van de belangstelling van de boerenzoons voor het landbouwonderwijs, LandbouwEconomisch Instituut Afdeling Streekonderzoek 361 (The Hague: Landbouw-Economisch Instituut, 1961), 61. ${ }^{67}$ DA, RvD, inv. nr. 27, Ingekomen stukken en kopieën van verzonden stukken 1928, Letter from 24 May 1918. ${ }^{68}$ By 1955, 21\% of all Dutch farmers with 1-5 hectares (many of which agricultural labourers who had to perform wage labour to secure a living) had received agricultural education. The 1955 survey on which these data are based was the agricultural census (the Landbouwtelling), conducted by the Centraal Bureau voor de Statistiek in May 1955. The outcomes of this survey have been discussed in A.W. van den Ban, Boer en landbouwonderwijs. De landbouwkundige ontwikkeling van de Nederlandse boeren, Bulletin Afdeling Sociologie en Sociografie van de Landbouwhogeschool 8 (Wageningen: Afdeling Sociologie en Sociografie van de Landbouwhogeschool, 1957) and, for Drenthe in particular, in Dekker, Landbouwonderwijs in Drenthe. Kwantitatieve en kwalitatieve analyse van de belangstelling van de boerenzoons voor het landbouwonderwijs.
} 
the Plant Breeding Institute in Wageningen, while sending samples of fertilizers and soils to experiment stations. Fertilizer traders, including the Centraal Bureau, the United Kali Company (Vereenigde Kalimaatschappij), and IG Farben, wrote Elema to introduce new fertilizers, to have him test the applicability of their products on Drenthe's soils, or to complain about advices in which he allegedly sold their product short. ${ }^{69}$ Elema was the entry to Drenthe's agricultural sector, while he himself upheld his network to maintain access to new knowledge and information.

\section{Graph 4.4, Elema's written and oral advices per year, 1895-1936}

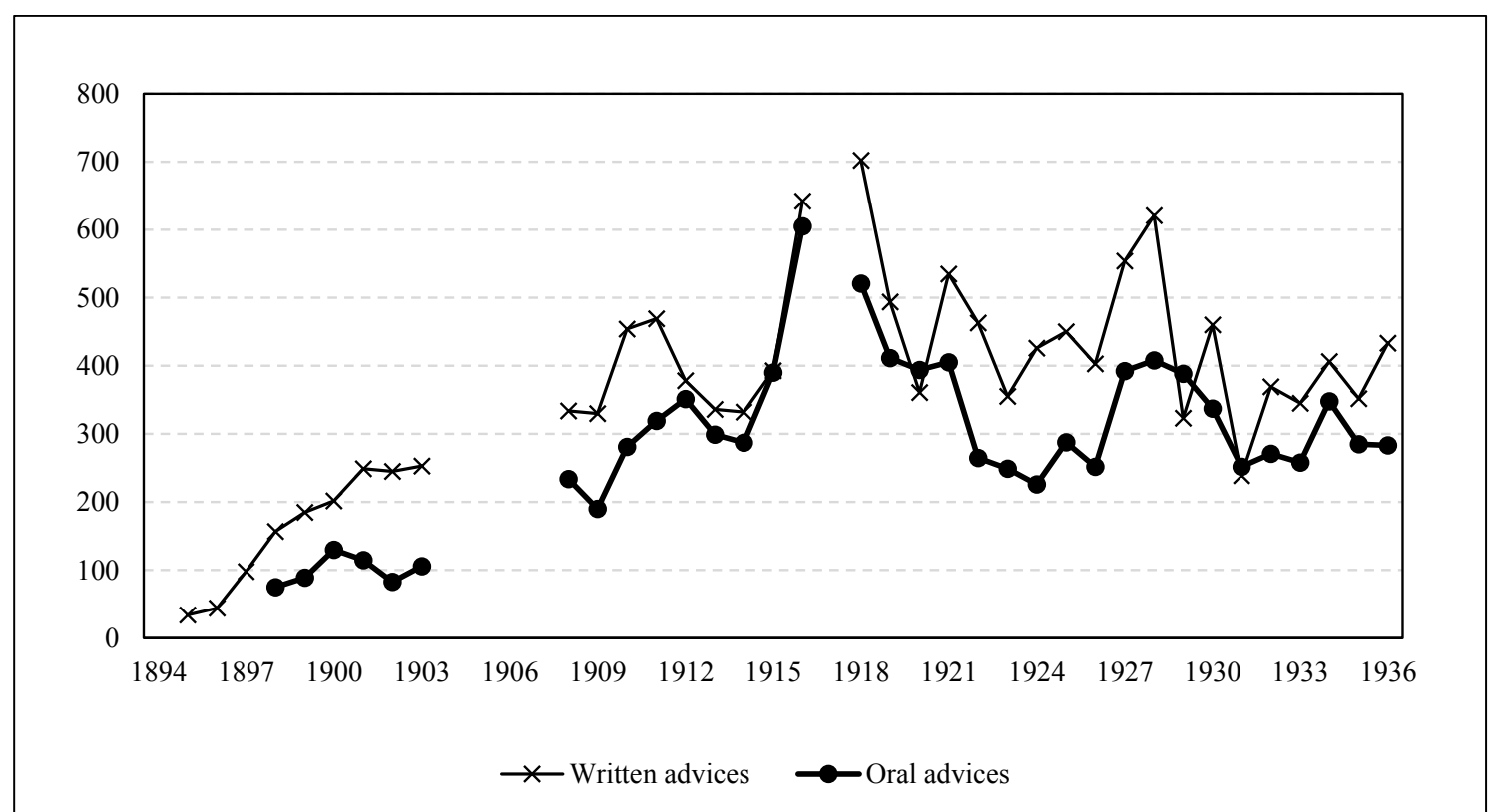

Source: DA, RvD, inv. nr. 30, Jaarverslagen 1895-1914, inv. nr 31, Jaarverslagen 1915-1925, inv. nr. 32, Jaarverslagen 1925-1936.

By setting up various knowledge networks, Elema eventually gained the trust of the local farming population. Throughout his tenure in Drenthe, farmers found their way to their consultant more easily. Graph 4.4 shows that his written and oral advices increased gradually

\footnotetext{
${ }^{69}$ In March 1928 Elema had a dispute with the Dutch agent of IG Farben, who had analysed 31 of Elema's advices published in the Drents Landbouwblad in 1927 and 1928. The agent complained that none of these advices included products from IG Farben. DA, RvD, Inv. Nr. 27, Ingekomen stukken en kopieën van verzonden stukken 1927-1930, correspondence in March 1928.
} 
until the 1910s and peaked during the First World War and at the end of the 1920s (particularly the written advices).$^{70}$ The overall increase in advices stem from a growing need among Drenthe's farmers to profit from Elema's expertise. Although Elema disposed of most of his written advices, his correspondence contains some illuminating examples of what Elema and individual farmers wrote about. Fertilization was the most discussed topic. Some wrote to Elema out of desperation: harvests had failed or production costs had risen - might artificial fertilizer be the solution? In October 1899, for instance, one farmer wrote that the potatoes he had cultivated on former wood lands had failed to grow, even though the plot had been fertilized with urban waste. How much artificial fertilizers, this farmer wondered, would make potato cultivation on this plot possible $?^{71}$ Another farmer, writing in 1901, also required advice on how to shift from urban waste to artificial fertilizers, and included a sketch and a short description of his fields ('the soil lets water through perfectly') to give an idea of how the plot in question looked like. ${ }^{72}$

In other instances, farmers were familiar with artificial fertilizers, but wrote to get more detailed information or to give feedback on earlier recommendations. In 1899 one farmer wrote that Elema's earlier advice on fertilization had worked out for potato cultivation, but not for the cultivation of rye. ${ }^{73}$ In 1901 one farmer, having successfully applied patent-kali, was advised by other farmers to combine this particular fertilizer with legumes and now wrote Elema to

\footnotetext{
${ }^{70}$ The oral advices in 1930 do not include the huge amount of 800 sugar beet plots which Elema visited. Because the price of sugar was guaranteed by the government during the Depression, many farmers in Drenthe shifted to this crop with which they had little familiarity - Elema had to visit the field ('in loco inquiry', as he called it) to offer information on the right fertilization.

${ }_{71}$ ' $\mathrm{Nu}$ wil ik het bemesten met kunstmest en hoe veel moet ik daar op hebben, het is ongeveer een half bunder en is zandgrond. Mijnheer ik hoop dat $u$ aan mijn verzoek zult voldoen'. DA, RvD, inv. nr. 10, Ingekomen stukken en kopieën van verzonden stukken 1899-1900, Letter from October 29, 1899, numbered 405.

72 'De grond (ongeveer 1 bunder) wordt jaarlijks bemest met groninger koemest en is in goeden staat; nu wou ik wel eens kunstmest probeeren. De schetsen aan de achterzijde geven u eenigsinds de wijze van de bebouwing te zien.' DA, RvD, inv. nr. 11, Ingekomen stukken en kopieën van verzonden stukken 1901, Letter from October 21, 1901 , numbered 493.

73 'Dit jaar heb ik aardappels en rogge verbouwd op aangemaakte dalgrond en geheel behandeld volgens uw advies. De uitkomst aan aardappelen is bevredigend met het oog op de omstandigheden en de rogge slecht. [...] Ik heb toen bemest met $40 \mathrm{hl}$. kalk, 1700 kainiet, $1000 \mathrm{~kg}$ slakken. Gaarne zou ik nu weer uw advies inwinnen welke en hoeveel aan de kunstmeststoffen ik nu weer in datzelfde land moet gebruiken.' DA, RvD, inv. nr. 10, Ingekomen stukken en kopieën van verzonden stukken 1899-1900, Letter from October 10, 1899, numbered 364.
} 
have these recommendations validated. ${ }^{74}$ In 1909 another farmer wrote to gather information about alternatives for Thomas slag, to which Elema responded with a review of various different fertilizers, including their nitrogen content and the soil types for which they were most suitable - apparently Elema did not underestimate this farmer's ability to apprehend chemical information. ${ }^{75}$ Another farmer, as a last example, wanted to specialize in the production of seeds and asked Elema to recommend relevant literature, also suggesting that Elema publish his answer in the Drents Landbouwblad so that others might benefit. ${ }^{76}$ These examples indicate that farmers trusted Elema's expertise as well as the various knowledge channels (press, literature, etc.) he provided.

Although not all Dutch public agricultural consultants might have been as impactful as Elema seems to have been, they did share Elema's convictions, methods, and aims. They all had as their core assignments to propagandize 'rationalized farming' and to facilitate the knowledge exchange between farmers themselves and between farmers and innovationproducing actors through press, public lectures, and education. The role of public agricultural consultants in the knowledge exchange on the local level, the case of Jakob Elema has shown, can best be summarized in two points. First, they established the necessary infrastructure, as they often were the driving force behind agricultural press, education, and public lectures, all platforms where their expertise and the experience of individual farmers could meet. Second, they gained the trust of local farming populations. Once gaining knowledge through 'traditional' channels (family tradition, village community, etc.), Dutch farmers had to increasingly rely on knowledge based on scientific findings and produced by experiment

\footnotetext{
${ }^{74}$ DA, RvD, inv. nr. 11, Ingekomen stukken en kopieën van verzonden stukken 1901, Letter from July 23, 1901, not numbered.

${ }^{75}$ DA, RvD, inv. nr. 16, Ingekomen stukken en kopieën van verzonden stukken 1909, Letter from May 25, 1909.

76 'Als beginnende teler van fijne zaden, zou ik gaarne in bezit komen van literatuur in dezen, bevattende eene beschrijving van cultuurwijze, afzet, verbruik, enz. Ook interesseer ik me voor graszaden. Is U wellicht in staat en bereid me een(ige) werkje(s) op te geven met vermelding zoo mogelijk van uitgevers en prijs? Bijvoorbaat mijn vriendelijke dank. Een antwoord in het Drentsch Landb. Blad zou misschien meerdere kunnen dienen.' DA, RvD, inv. nr. 27, Ingekomen stukken en kopieën van verzonden stukken 1927-1930, Letter without date and not numbered.
} 
stations, research institutes, and formal education. Public agricultural consultants were the personification of, as well as the gateway to, this new way of acquiring knowledge.

\subsection{Conclusion}

The transformation of Dutch arable farming since the late nineteenth century is most clearly illustrated by the growing usage of artificial fertilizers. This chapter has aimed to understand the large increase in Dutch artificial fertilizer usage between the 1890s and the 1940s. Prior to the 1890 s, the Netherlands was only a small user of artificial fertilizer. At the end of the nineteenth century, however, a combination of economic and agronomic factors caused Dutch artificial fertilizer usage to increase - ultimately making the Dutch average of artificial fertilizer usage per hectare the highest in Europe. This resulted in a growing need for reliable, objective, and detailed knowledge on artificial fertilizers. An improved knowledge exchange was required to deal with various challenges - the weak position of individual farmers vis-a-vis traders and the fertilizer industry, for instance - and to apply artificial fertilizers efficiently; individual farmers had to know, simply put, when, how, and which artificial fertilizers to use.

This need was largely met by public agricultural consultancy. Agricultural consultants, as the example of Jakob Elema has shown, introduced channels and platforms, be it press, education, or public lectures, at which knowledge exchange took place. Dutch public agricultural consultancy established a knowledge exchange on the national level while also facilitating a knowledge exchange on the local level, between farmers themselves. The improved and accelerating knowledge exchange was the required condition without which the diffusion of artificial fertilizers could not have taken place. This argument also works in the opposite direction: the knowledge exchange itself was a spur for a more intensive usage of artificial fertilizers, as it increased familiarity with artificial fertilizers and decreased information asymmetry, reducing the risk to innovate and persuading Dutch farmers to apply 
artificial fertilizers more abundantly. The improved knowledge exchange, in other words, was a reaction to knowledge intensification, but was itself a driver for ongoing knowledge intensification. Although Dutch public agricultural consultancy was an important component of this knowledge intensification spiral, this is not to say that all the knowledge-intensification of Dutch agriculture resulted from top-down policy. The following chapter shows how cooperatives, organized and governed by farmers themselves, also played their part. 


\section{CHAPTER V}

\section{MARKETING COOPERATIVES AND CROP VARIETIES}

\subsection{Introduction}

The success of Dutch agricultural innovation, this study has thus far shown, can partly be attributed to state efforts. The knowledge intensification of Dutch farming since the late nineteenth century prompted the Dutch government to set up agricultural education, to fund R\&D, and to organize consultancy. The previous chapters have also hinted at another characteristic of the Dutch agricultural sector that partly resulted from knowledge intensification: the high degree of self-organization of the Dutch farming population. Chapter 3 has shown that Dutch farmers organized themselves, voiced their needs, and consequently shaped government agricultural policy. Supply cooperatives, chapter 4 noted, gave Dutch farmers access to fertilizers, feed, and other inputs.

The emergence of cooperatives since the late nineteenth century drastically changed Dutch agriculture. Around 1850 Dutch farmers traded their products and their inputs with the village grocer, at local markets, or with each other. Yet, the rise of the processing industry and the increasing reliance on imported inputs impersonalized this relationship with suppliers and purchasers. The exchange of goods became organized through formal contracts rather than through informal ties and the bargaining power of an individual farmer with regard to food companies, not rarely multinationals, diminished significantly. Cooperatives gave back this previously lost control and granted access to foreign markets.

This story is not uniquely Dutch. Agricultural cooperatives played an important role in many parts of Europe, as is illustrated in the famous cases of the dairy cooperatives in Denmark and the Raiffeisen banks in Germany. What does set the Dutch case apart, however, is its wide variety of agricultural cooperatives. Dutch cooperatives did not only dominate Dutch livestock 
farming, but were also hugely influential in the horticultural and arable sector. What is more, Dutch cooperatives had an unusually high membership rate. Around 1950, at least $90 \%$ of the Dutch farmers was a member of a cooperative. By the outbreak of the Second World War, about $65 \%$ of the artificial fertilizers and feed came from supply cooperatives and approximately $80 \%$ of the butter, $75 \%$ of the cheese, $90 \%$ of the potato starch, $60 \%$ of the beet sugar, $90 \%$ of the flowers, $60 \%$ of the fruit, and a full $100 \%$ of the vegetables produced in the Netherlands were processed or traded by cooperatives. ${ }^{1}$ To say that the Dutch agricultural sector was shaped by cooperatives is an understatement.

This chapter seeks to understand the relationship between cooperatives and agricultural innovation. Historians have long discussed to what extent economic organizations promote innovation. ${ }^{2}$ Some have claimed that economic organizations such as guilds, firms, cartels, and trade associations prevented technological progress through their efforts for rent-seeking and protection of privileges. ${ }^{3}$ Others, by contrast, argued that these economic organizations provided networks which accumulated social and human capital and diffused innovation. ${ }^{4}$ The first view highlights the presumed conservatism of these economic organizations, the latter presents them as vehicles of progress.

\footnotetext{
${ }^{1}$ Ronald Rommes, Voor en door boeren? De opkomst van het coöperatiewezen in de Nederlandse landbouw vóór de Tweede Wereldoorlog (Hilversum: Verloren, 2014), 16.

${ }^{2}$ I follow the definition of economic organizations as introduced by Douglass North: 'If institutions are the rules of the game, organizations and their entrepreneurs are the players. Organizations are made up of groups of individuals bound together by some common purpose to achieve certain objectives'. Quote from North's Nobel Prize Lecture on December 9, 1993. See Torsten Persson, ed., Nobel Lectures, Economics 1991-1995 (Singapore: World Scientific Publishing, 1997).

${ }^{3}$ See, for instance, the chapter on innovation in Sheilagh Ogilvie, The European Guilds. An Economic Analysis (Princeton and Oxford: Princeton University Press, 2019).

${ }^{4}$ S.R. Epstein and Maarten Prak, "Introduction: Guilds, Innovation, and the European Economy, 1400-1800," in Guilds, Innovation, and the European Economy, 1400-1800, ed. S.R. Epstein and Maarten Prak (Cambridge: Cambridge University Press, 2008), 1-24. Alain Cortat, "How Cartels Stimulate Innovation and R\&D: Swiss Cable Firms, Innovation and the Cartel Question," Business History, 51, no. 5 (September 2009): 754-69. Francesca Carnevali, "Social Capital and Trade Associations in America, c. 1860-1914: A Microhistory Approach," Economic History Review, 64, no. 3 (August 2011): 905-28. The connection between firms and innovation is extensively studied by business historians. For a literature overview, see Geoffrey Jones and Walter A. Friedman, "Business History: Time for Debate," Business History Review, 85, no. 1 (March 2011): 1-8.
} 
Also agricultural cooperatives have been gradually attracting attention from historians interested in innovation. Some have described agricultural cooperatives as 'information machines' characterized by their ability to easily share knowledge and grant access to technology. The alternative account is that the democratic organizational structure made agricultural cooperatives stagnant; they served their stakeholders' interests by maintaining the status quo. Lack of capital, especially when the cooperatives were set up by smallholders, might have also made them risk-averse. ${ }^{5}$

Whereas these notions are based on cooperation within the dairy industry, the wine industry, and in rural banking, this chapter gives special attention to marketing cooperatives, which are heavily understudied. ${ }^{6}$ The focus of this chapter is particularly on the link between marketing cooperatives and biological innovation. Since the late nineteenth century Dutch productivity was increased by, among other things, breeding crop varieties with higher yields, with improved disease resistance, or with better responsiveness to artificial fertilizers. The availability of an increasingly wide range of different crop varieties increasingly complicated the choice of which variety to growth, also known as the 'variety question' (rassenvraagstuk). Although farmers had multiple channels through which information on crop varieties could be accessed, this chapter argues that marketing cooperatives were of particular importance. Marketing cooperatives gave access to seeds (and other inputs) that would have otherwise remained inaccessible, they facilitated an exchange of knowledge between farmers, and they accumulated specialized information on one single crop, variety or product through their R\&D. The internal organisation of the marketing cooperatives, with strong communal identity, mutual

\footnotetext{
5 T.W. Guinnane, "Cooperatives as Information Machines: German Rural Credit Cooperatives, 1883-1994," Journal of Economic History, 61, no. 2 (2001): 366-89. Ingrid Henriksen and Morten Hviid, "Diffusion of New Technology and Complementary Best Practice: A Case Study," European Review of Economic History, 9 (2005): 365-97. Jordi Planas, "The Emergence of Winemaking Cooperatives in Catalonia," Business History, 58 (2016): 264-82.

${ }^{6}$ Marketing cooperatives process, package, and market agricultural products for their members. They are therefore different than supply cooperatives, which buy, store, and distribute inputs for their members.
} 
trust, and peer pressure, stimulated members to improve their farming methods and to meet higher standards.

This argument is mainly based the archival records (particularly minutes, year reports, and correspondence) of seven sugar beet cooperatives between circa 1890 and 1970. Once fully controlled by the private industry, Dutch sugar beet production was dominated by cooperatives within less than two decades after the first sugar beet cooperative was established in 1899 . The success of these sugar beet cooperatives, discussed in more detail below, as well as the richness of their archival records make them excellent objects of study. As innovation within sugar beet production for long consisted of breeding improved varieties rather than mechanization, the case of the Dutch sugar beet cooperatives gives a clear insight into the link between marketing cooperatives and the 'variety question'. Moreover, as the Dutch sugar beet cooperatives resembled other Dutch marketing cooperatives (particularly potato starch cooperatives and strawboard cooperatives) in their raison d'être, historical development, and structure, conclusions drawn from sugar beet cooperatives can be applied to other Dutch marketing cooperatives.

This chapter continues as follows. The following section shows that the prevalent narrative about the cooperative movement in European agriculture - smallholders set up cooperatives to jointly have access to certain technology - does not apply to Dutch marketing cooperatives, which were instead set up to break the monopsony power of the private industry. Section 5.3 explains how the internal organisation of Dutch sugar beet cooperatives stimulated its members to improve farming methods. Section 5.4 shows that the Dutch sugar beet cooperatives jointly set up R\&D to improve the knowledge of various sugar beet varieties. The last section concludes. 


\subsection{The rise of Dutch marketing cooperatives}

International historiography on agricultural cooperatives has focused largely on Danish dairy cooperatives. The literature on Danish dairy cooperatives finds the motivation to cooperate in the need of farmers, particularly smallholders, to jointly take advantage of new technology. Danish farmers established dairy cooperatives to utilize a specific technological innovation: the automatic cream separator invented in $1878 .{ }^{7}$ Ingrid Henriksen et al write that 'the technological and institutional determinants of the success [of the Danish dairy industry] are thus clearly interdependent: the invention of the automatic cream separator led to the success of the cooperative movement which in turn allowed for the successful use of the technology' ${ }^{8}$

This resource-pooling argument seems to have been dominating historiography. Eva Fernández, for instance, has compared European agricultural cooperation with equivalents in the New World, especially in North America. North American farmers cooperated to solve market failures, such as asymmetric information, hold-up problems, or monopsony. ${ }^{9}$ They cooperated to gain access to markets without having profits absorbed by interfering intermediates. When discussing Europe, Fernández applies the resource-pooling argument, originally based on the Danish case, to explain the entire European agricultural cooperative movement. She argues that European farmers cooperated to get access to technology which would be inaccessible for the individual farmers. ${ }^{10}$

When looking at the sudden rise of marketing cooperatives in Dutch arable farming since the late nineteenth century, the resource-pooling argument does not hold. A close look at

\footnotetext{
${ }^{7}$ Ingrid Henriksen, “Avoiding Lock-in: Cooperative Creameries in Denmark, 1882-1903," European Review of Economic History, 3, no. 1 (April 1999): 57-78.

${ }^{8}$ Ingrid Henriksen, Markus Lampe, and Paul Sharp, "The Role of Technology and Institutions for Growth: Danish Creameries in the Late Nineteenth Century," European Review of Economic History, 15, no. 3 (2011): 476.

${ }^{9}$ Asymmetric information refers to a situation in which a buyer has more or better knowledge than a seller (or vice versa), creating an imbalance of power. Hold-up problems might occur when one of two parties, having agreed upon a future transaction, is reluctant (or unable) to respect the contract. A monopsony is the opposite of a monopoly: one buyer (or a small number of buyers) and a large number of sellers.

${ }^{10}$ Eva Fernández, "Selling Agricultural Products: Farmers' Co-Operatives in Production and Marketing, 18801930,” Business History, 56, no. 4 (2014): 547-68.
} 
the order of events reveals that Dutch arable farmers did not cooperate exclusively to collectively invest in certain technologies. Somewhat older Dutch historical literature, which seems not to have been picked up by international historiography, has since long argued that Dutch marketing cooperatives were set up to break with the processing industry. ${ }^{11}$ Since the mid-nineteenth century Dutch arable farmers became increasingly linked with the processing industry. Discontent with the industry's monopsony power caused Dutch arable farmers to set up processing factories themselves, thereby circumventing the private industry. By cooperating, farmers organized the processing industry on their own terms, with a stronger say for the individual farmer.

A telling example is the emergence of the cooperative potato starch factories. The cultivation of starch potatoes in the Netherlands took off in the mid-nineteenth century. The potato starch industry, clustered in the northern provinces of Groningen and Drenthe, was largely dominated by one enterprise, the W.A. Scholten Company. ${ }^{12}$ This company, established in 1841, was often at odds with its suppliers, local potato farmers, particularly in times of falling prices. In the 1890s, during another price drop, Scholten persuaded its smaller competitors to make agreements about the prices they would pay for potatoes. In 1897 discontent with this cartelization resulted in the establishment of the first potato starch cooperative and other potato starch cooperatives swiftly followed. As early as 1911 the cooperatives processed more starch than the private industry and by 1919 twelve cooperatives jointly formed one central sales centre, the Aardappelmeelverkoopbureau ('Potato Starch Selling Centre', shortly known as Avebe). The potato starch cooperatives and Avebe started dominating Dutch potato starch

\footnotetext{
${ }^{11}$ Particularly Van Stuijvenberg has written extensively about the Dutch agricultural cooperative movement. On the origins of Dutch marketing cooperatives, see for instance J.H. van Stuijvenberg, De ontstaansgronden van de landbouwcoöperatie in her-overweging (Den Haag: Nationale Coöperatieve Raad voor Land- en Tuinbouw, 1977). ${ }^{12}$ Dorien Knaap, "Voor geld is altijd wel een plaats te vinden": de firma W.A. Scholten (1841-1892) De eerste Nederlandse industriële multinational, Groningse Historische Reeks 27 (Assen: Koninklijke Van Gorcum, 2004).
} 
production at the expense of the private industry. By 1950, fifteen of all twenty Dutch potato starch factories were cooperatively organized. ${ }^{13}$

The rise of the Dutch strawboard cooperatives is remarkably similar. As with the potato starch industry, the strawboard industry expanded in the second half of the nineteenth century and had its early origins in Groningen in the north. Straw, a by-product of wheat production, had long been used as cattle feed. Mechanization and the introduction of imported feeds allowed straw to be used for other purposes. After the first private strawboard factory was established in 1869 , the first strawboard cooperative was established in 1899. By 1939 there were nine private factories and nine cooperatively-organized factories, with all but one of these eighteen location in the province of Groningen. ${ }^{14}$

The history of the Dutch sugar beet industry follows the same pattern: expanding gradually after the 1850 s, the industry was at first fully privately owned, only to become predominantly farmer-owned in the early twentieth century. The early origins of the Dutch sugar beet industry and the rise to power of sugar beet cooperatives, discussed below in more detail, granted farmers more control and a stronger voice over inputs, including the varieties to be cultivated, which, as the following sections will argue, benefitted agricultural innovation.

Because Dutch sugar refining factories for long used sugarcane as their raw material, sugar beet cultivation in the Netherlands was rare during most parts of the nineteenth century. In 1865 , for instance, merely 2,146 hectares were cultivated with sugar beets, an extremely low figure compared to potato and wheat, two other major Dutch cash crops (see Graph 5.1). ${ }^{15}$ During the second half of the nineteenth century, however, Dutch sugar beet cultivation increased rapidly, with larger growth rates than for the cultivation of potatoes and wheat. While potato starch production and strawboard production were fully concentrated in the north, the

\footnotetext{
${ }^{13}$ J. Bieleman, Boeren in Nederland. Geschiedenis van de landbouw 1500-2000 (Amsterdam: Boom, 2008), 43032.

${ }^{14}$ Bieleman, Boeren in Nederland. Geschiedenis van de landbouw 1500-2000, 348-49.

${ }^{15} 111$ jaar statistiek in tijdreeksen (CBS 2010), 96-99.
} 
increase in sugar beet cultivation occurred mainly in the south-western sea clay areas, where farmers - since long exporting cash crops to Belgium - were affected by the growing demand for sugar beets from Belgian sugar factories and where the discovery of artificial alizarin made madder (an important crop in the sea clay areas) unneeded as a raw material for dyes. ${ }^{16}$ Moreover, at the end of the 1870s the Agrarian Depression reduced profits made with other cash crops, which gave many Dutch farmers no other options but to turn to sugar beets. ${ }^{17}$

The expanding Dutch sugar beet industry was fully owned by private investors, as was the case with sugar industries in other Western European countries. Private sugar beet factories purchased sugar beets from farmers or, less common, had wage labourers cultivate sugar beets on leased land. ${ }^{18}$ By committing themselves to the private industry, Dutch sugar beet farmers not only secured the sale of their crops but also guaranteed advance payments with which they could purchase necessary inputs, mainly fertilizers and seeds. ${ }^{19}$ As the ties between farmers and private industry intensified, problems came to the fore. Because the Dutch private sugar

\footnotetext{
${ }^{16}$ The price for madder dropped from 30 guilders per 10 kilos in 1869 to 12 guilders in 1876. Bieleman, Boeren in Nederland. Geschiedenis van de landbouw 1500-2000, 344. The demand for sugar beets further increased in the early 1870s when London replaced Amsterdam as the European staple market for sugarcane, after which Dutch sugar factories shifted to sugar beets as their raw material and moved from Amsterdam to the Dutch countryside. In her dissertation on the business history of the sugar beet cooperative at Puttershoek, Frida Terlouw shows that the so-called cultivation system in the Dutch Indies, in which the Dutch state organized the production of sugar cane, was abolished in 1870, privatizing the trade in sugar cane. In 1874 the British government repealed import duties on sugar cane, which opened up the British market for sugar (cane) from the Dutch Indies. As a result, import of cane sugar from Java to the Netherlands declined from 1,515,000 tons in 1871 to 7,000 tons in 1905. Dutch sugar consumption, on the other hand, expanded continuously from the mid-nineteenth century until the Second World War. Frida Terlouw, "De geschiedenis van de bietsuikerindustrie in Nederland en van de Coöperatieve Suikerfabriek en Raffinaderij g.a. Puttershoek 1912-1966 in het bijzonder met inachtneming van de overheidspolitiek en de verhouding tussen de coöperatieve en de particuliere industrie" (Nederlandse Economische Hogeschool, 1969), 5, 10 and 204.

${ }^{17}$ In his monograph on the history of agriculture in the province of Zeeland, Peter Priester also mentions the increased availability of artificial fertilizers and improved infrastructure as possible explanations for the sudden expansion of sugar beet cultivation. Peter Priester, Geschiedenis van de Zeeuwse landbouw circa 1600-1910, AAG Bijdragen 37 (Wageningen, 1998), 398-402.

${ }^{18}$ J.A. Perkins, “The Organisation of German Industry, 1850-1930: The Case of Beet-Sugar Production,” Journal of European Economic History, 19 (1990): 551. J.A. Perkins, "The Agricultural Revolution in Germany 18501914," Journal of European Economic History, 10 (1981): 96-97. Martine Goossens and Koen Dries, "Twee vroege voorbeelden van agro-business: de suikerbietindustrie en de graanstokerijen," in Nijver België. Het industriële landschap omstreeks 1850, ed. Bart van der Herten, Michel Oris, and Jan Rogiers, Ortelius Series (MIM, 1995), 269.

${ }_{19}$ M. Bakker, Ondernemerschap en vernieuwing. De Nederlandse bietsuikerindustrie, NEHA-Jaarboek voor economische, bedrijfs- en techniekgeschiedenis 3 (Amsterdam: NEHA, 1989), 92-95. For a business history of the Dutch private sugar beet industry in the twentieth century, see Keetie E. Sluyterman, Driekwart eeuw CSM. Cash flow, strategie en mensen (CSM, 1995).
} 
factories were the only potential buyers of sugar beets, Dutch farmers were confronted with a weak bargaining position. Even though discontent with the private industry became widespread among Dutch farmers, they often had no other alternative than to concede to unfavourable contracts. In 1897 a Dutch socialist cynically portrayed the private factories as 'angels sent by God', who 'delivered' farmers from their financial obligations by issuing 'sugar sweet' contracts, by granting advance payments, and by providing the farmers with 'blessed seed for holy sugar beets'. When farmers instead cultivated other varieties they were breaking 'the Eleventh Commandment' and would be thrown into the 'deepest darkness', as their crops would be rejected, and no payment would be made. Sugar beet cultivation, this author concluded, ultimately caused soil depletion and would thus bring farmers deeper into trouble. ${ }^{20}$

\footnotetext{
20 'Er kwamen engelen, die luisterden naar den naam van Heere \& Co., Beetwortelsuikerfabrikanten te Statendam bij Geertruidenberg. (...) En om u op te heffen uit den poel van ellende (...) zullen wij u desverkiezend honderd gulden op voorschot geven voor elken bunder die gij zult bezaaien met het gezegende zaad der heilige suikerbieten, en voor dit alles behoeft gij niets te doen dan uw naam te teekenen, onder een suikerzoet kontrakt (...). Sommige boeren hadden zonder scheikundig onderzoek bemerkt, dat, wanneer ze zelf suikerbietenzaad teelden en dát zaaiden, dat dan de suikerbieten oneindig veel zwaarder groeiden, maar dezulken zondigden tegen de laatste alinea van 't Elfde Gebod van Heere \& Co. en zij werden uitgeworpen in de buitenste duisternis, d.w.z.: Heere \& Co. verkozen hunne suikerbieten niet in ontvangst te nemen. De suikerbieten-kontrakten maaken dus voor de boeren 'n gaatje om ' $n$ gat te stoppen; maar naarmate de suikerbieten dunner werden, werd 't gat grooter, zoodat ten slotte menig boer verzonk in 't groote gate gemaakt door suikerbieten.' A. van Emmenes, Kikkerdorp en de Kikkerdorpers. Geldersche Historische Novelle, bewerkt in de Strafgevangenis te Nieuwer-Amstel, vol. 3, Bibliotheek voor Ontspanning en Ontwikkeling 7 (Amsterdam: De Roode Bibliotheek, 1897), 95-97.
} 
Graph 5.1. Acreage of sugar beets, potatoes, and wheat, 1850-1970 (in hectares).

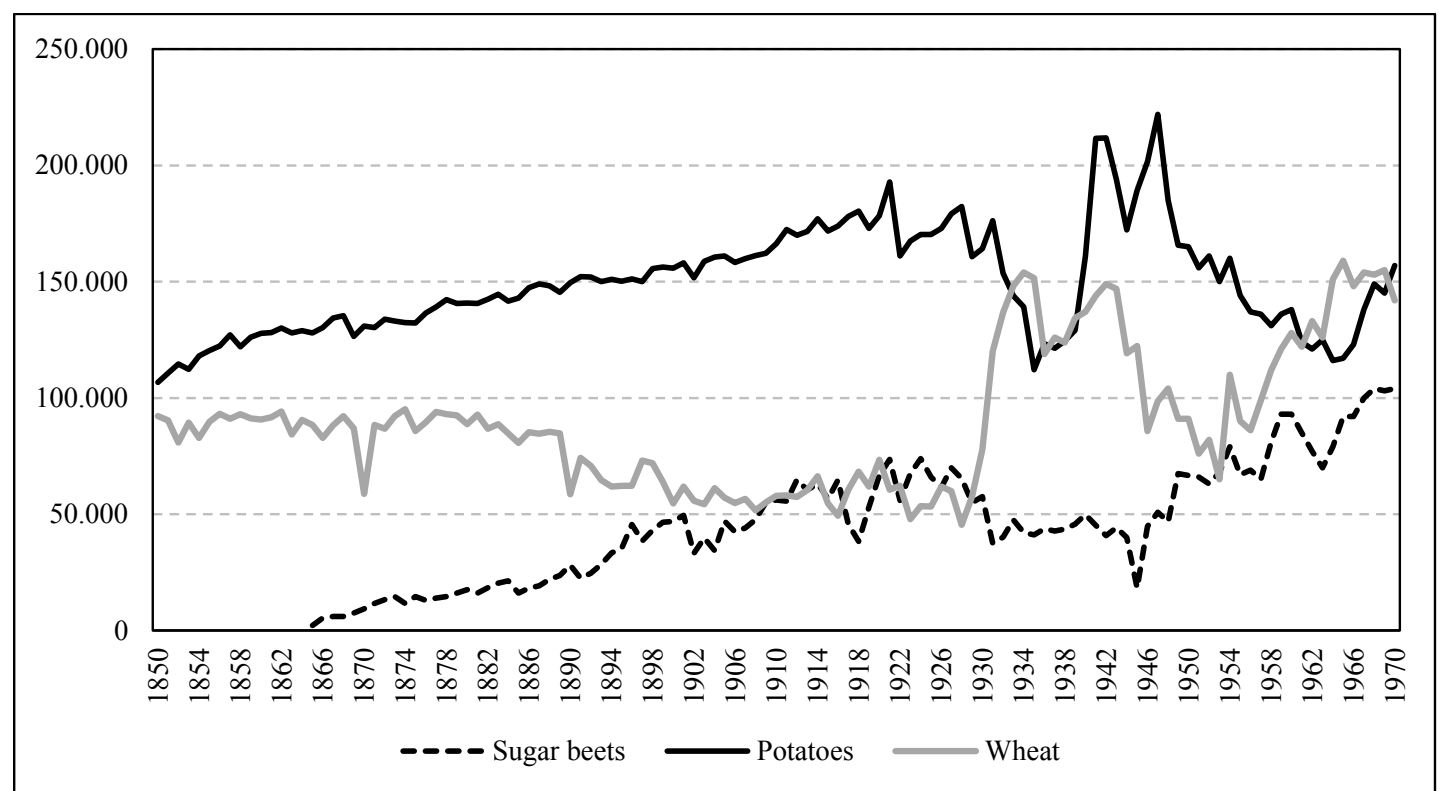

Source: Table VII.2 in Knibbe, Agriculture in the Netherlands 1851-1950, 294-297 and Table 8a in 111 jaar statistiek in tijdreeksen (CBS 2010), 96-99.

The unbalanced power over varieties and other inputs caused farmers to lose their influence on the inputs they wanted to use. Agreements between factories and farmers were usually documented in one-year contracts. Apart from stipulating the price and the quantity of beets to be delivered, these contracts dictated in detail which varieties, fertilizers and cultivation methods were to be used. ${ }^{21}$ The industry usually provided varieties and fertilizers directly and against low payments (or without charge altogether) as these were often hard to come by for individual farmers themselves. These inputs improved yields but often intensified the labour of the individual farmers and depleted the soil of their fields. ${ }^{22}$ This issue was related to another source of controversy: the price for the beets. Farmers were initially paid by the weight of sugar beets. It was discovered, however, that the weight of the beets does not correlate directly with

\footnotetext{
${ }^{21}$ In some instances the contracts did not even allow farmers to prepare their fields and sow their seeds themselves. Instead, the private sugar beet factories would send well-instructed wage labourers to ensure that the sowing was done properly.

${ }^{22}$ Terlouw, "De geschiedenis van de bietsuikerindustrie in Nederland en van de Coöperatieve Suikerfabriek en Raffinaderij g.a. Puttershoek 1912-1966 in het bijzonder met inachtneming van de overheidspolitiek en de verhouding tussen de coöperatieve en de particuliere industrie," 16.
} 
their sugar content. The private industry thus started breeding new sugar beet varieties, which had a higher sugar content but a lower overall weight, which consequently lowered the prices farmers received for their crops. ${ }^{23}$ Discontent with the private industry increased particularly when factories made price agreements. The Association of Sugar Factories (Bond van Suikerfabrikanten), established in 1875 , prescribed fixed prices for all its members since $1885 .{ }^{24}$ The farmers reacted on this cartelization by enhancing their bargaining power through local agricultural societies, which negotiated on their behalf. After initiatives to set up sugar beet cooperatives in 1878 and 1889 had failed, a local agricultural society in the region of Zeeuws-Vlaanderen mobilized enough farmers to jointly invest in a sugar beet factory. This first Dutch sugar beet cooperative, which had opened in Sas van Gent in 1899, paid its member for the sugar content of delivered beets rather than their weight, a price arrangement though to be more in line with the farmers' labour input. ${ }^{25}$

The example set in Sas van Gent was only followed elsewhere after the south-western part of the Netherlands, the centre of Dutch sugar beet cultivation, became dominated by one large enterprise, the Algemeene Suikermaatschappij ('General Sugar Company’, known as Asmij), which was notorious for its particularly unfavourable beet contracts. This company's growing monopsony power led to a counter-movement among farmers and the establishment of sugar beet cooperatives in Dinteloord (1908), Puttershoek (1912), Zevenbergen (1912), Roosendaal (1913), Groningen (1913), and Bergen op Zoom (1917-1929). Apart from the one in Groningen, organized by farmers in the northern provinces of Friesland and Groningen and thus called the 'Friesch-Groningsche', all sugar beet cooperatives were located in or around the

\footnotetext{
${ }^{23}$ Terlouw, "De geschiedenis van de bietsuikerindustrie in Nederland en van de Coöperatieve Suikerfabriek en Raffinaderij g.a. Puttershoek 1912-1966 in het bijzonder met inachtneming van de overheidspolitiek en de verhouding tussen de coöperatieve en de particuliere industrie," 15-16. Huub Surendonk, Groei uit suiker. Oorsprong en ontwikkeling van Coöperatie Cosun U.A. (1899-1999) (Breda: Cosun, 1999), 14.

${ }^{24}$ See the introduction to the archive inventory of the Friesch-Groningsche Coöperatieve Beetwortelsuikerfabriek: GA, FGCB.

${ }^{25}$ Rommes, Voor en door boeren? De opkomst van het coöperatiewezen in de Nederlandse landbouw vóór de Tweede Wereldoorlog, 118.
} 
southwest of the country (see Map 5.1). ${ }^{26}$ Besides the Bergen op Zoom cooperative, which closed down in 1929, all sugar beet cooperatives expanded swiftly. Already by 1913 two of the sugar beet cooperatives were among the hundred largest Dutch companies. ${ }^{27}$ While the sugar beet cooperatives jointly provided $47 \%$ of the total Dutch sugar production in 1920 , since the 1930 s they processed approximately $60 \%$ of the sugar beets grown in the Netherlands. ${ }^{28}$

The swift establishment of six sugar beet cooperatives between 1908 and 1917 coincided with a period during which sugar beet acreage increased significantly, even equalling wheat acreage (as shown in Graph 5.1). Apart from some short-lived dips, Dutch sugar beet cultivation followed an overall upward trend until the 1930s. Sugar beet cultivation expanded again after the Second World War only, an increase caused by farmers in the east, the southeast, and in the polders (reclaimed during the 1940s and the 1950s, particularly the Noordoostpolder and the Flevopolder), turning to sugar beet cultivation. ${ }^{29}$ In the century after the 1860 s, sugar beet cultivation had grown from non-existent to approximately 100,000 hectares.

\footnotetext{
${ }^{26}$ Surendonk, Groei uit suiker. Oorsprong en ontwikkeling van Coöperatie Cosun U.A. (1899-1999), 22. Terlouw, "De geschiedenis van de bietsuikerindustrie in Nederland en van de Coöperatieve Suikerfabriek en Raffinaderij g.a. Puttershoek 1912-1966 in het bijzonder met inachtneming van de overheidspolitiek en de verhouding tussen de coöperatieve en de particuliere industrie," 19-23.

${ }^{27}$ The two sugar beet cooperatives on the 1913 list of largest Dutch companies were the Sas van Gent cooperative and the Dinteloord cooperative. The Suiker Unie (Sugar Union) into which the sugar beet cooperatives merged in 1970 was the $15^{\text {th }}$ largest Dutch company by 1990 . See E. Bloemen, J. Kok, and J.L. van Zanden, De Top 100 van Industriële Bedrijven in Nederland 1913-1990 (The Hague: Adviesraad voor het Wetenschaps- en Technologiebeleid, 1993), 29-39.

${ }^{28}$ The 1920 data are found in a letter from the Dutch department of agriculture to the Sas van Gent sugar cooperative, 10th of November 1920. See Zeeuws Archief (hereafter ZA) entry nr. 455, Eerste Nederlandsche Coöperatieve Beetwortelsuikerfabriek, Sas van Gent, 1882-1991 (hereafter ENCBS), inv. nr. 38, Ingekomen en minuten van uitgaande stukken, 1900-1935. For the 1930s data, see Terlouw, "De geschiedenis van de bietsuikerindustrie in Nederland en van de Coöperatieve Suikerfabriek en Raffinaderij g.a. Puttershoek 1912-1966 in het bijzonder met inachtneming van de overheidspolitiek en de verhouding tussen de coöperatieve en de particuliere industrie," 48.

${ }^{29}$ Bieleman, Boeren in Nederland. Geschiedenis van de landbouw 1500-2000, 352-53.
} 


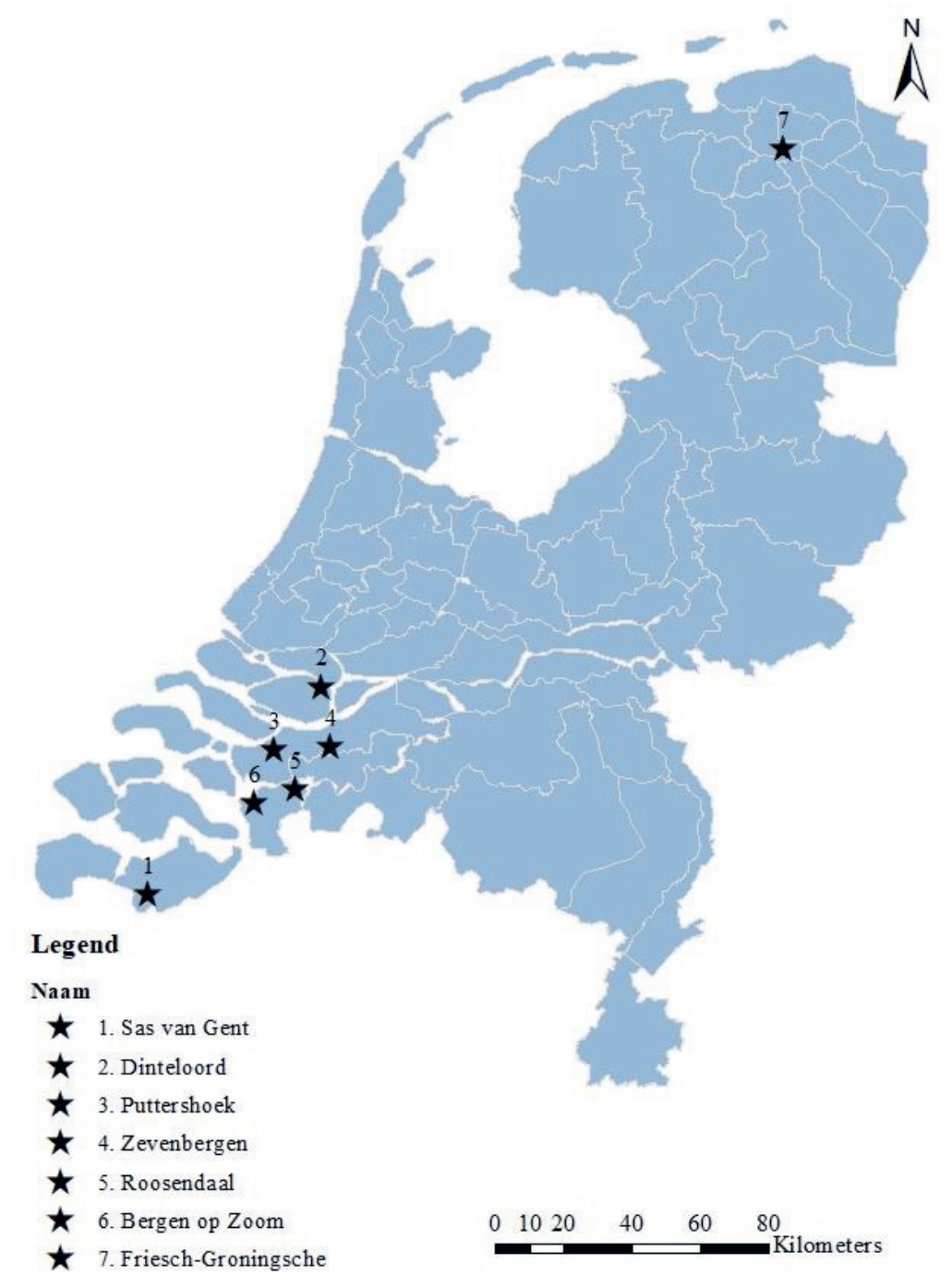

\subsection{The internal organisation of the Dutch sugar beet cooperatives}

Given their apparent success, it can be assumed that the Dutch sugar beet cooperatives contributed to innovation. Because sugar beet cultivation was only mechanized since the $1960 \mathrm{~s}$, productivity gains were mostly achieved by intensifying fertilizing and by breeding varieties with higher yields or with a higher sugar content. Graph 5.2 shows that Dutch sugar beet yields showed a downward trend from the 1860 s to the 1890 s, after which yields increased during the 1890s. The yields plateaued during the 1900s and 1910s, only to increase again since the 1920s. 
These yields are measured in kilograms per hectare and do not capture the sugar content of the beets. The sugar content at the Puttershoek cooperative rose from about $15 \%$ by 1900 to $17 \%$ in the $1960 \mathrm{~s}$, peaking at between 17.5 and $18.5 \%$ in the late $1920 \mathrm{~s} .^{30}$ This seemingly small increase could cause a significant increase in income, as the prices paid by the cooperatives were based on the sugar content of the delivered beets. The downward trend in sugar content since the late $1930 \mathrm{~s}$ - possibly related to a shifting focus in plant breeding, from an emphasis on increasing sugar content to an emphasis on growth in yields - was compensated by an overall yield increase.

The figures in Graph 5.2 reveal that, over time, Dutch sugar beet farmers found ways to increase productivity and to reach efficiency gains, thus becoming, simply put, better farmers. Ofcourse this improved innovation capacity cannot be attributed solely to the sugar beet cooperatives - innovation capacity could be enhanced by a wide range of factors. Still, the sugar beet cooperatives contributed to agricultural innovation in a number of ways, which are discussed below.

\footnotetext{
${ }^{30}$ Unfortunately, the Puttershoek cooperative figures are the only long-term time series of sugar content available. The Puttershoek cooperatives seems to have had excellent record-keeping given that their figures on sugar content were copied in the Dutch national agricultural statistics, the Verslagen van den Landbouw. Terlouw, "De geschiedenis van de bietsuikerindustrie in Nederland en van de Coöperatieve Suikerfabriek en Raffinaderij g.a. Puttershoek 1912-1966 in het bijzonder met inachtneming van de overheidspolitiek en de verhouding tussen de coöperatieve en de particuliere industrie," 200-201.
} 
Graph 5.2. Sugar beet yields (100 kg per hectare) and sugar content at the Puttershoek cooperative (measured as percentage of beet weight used for sugar extraction), 1865-1970

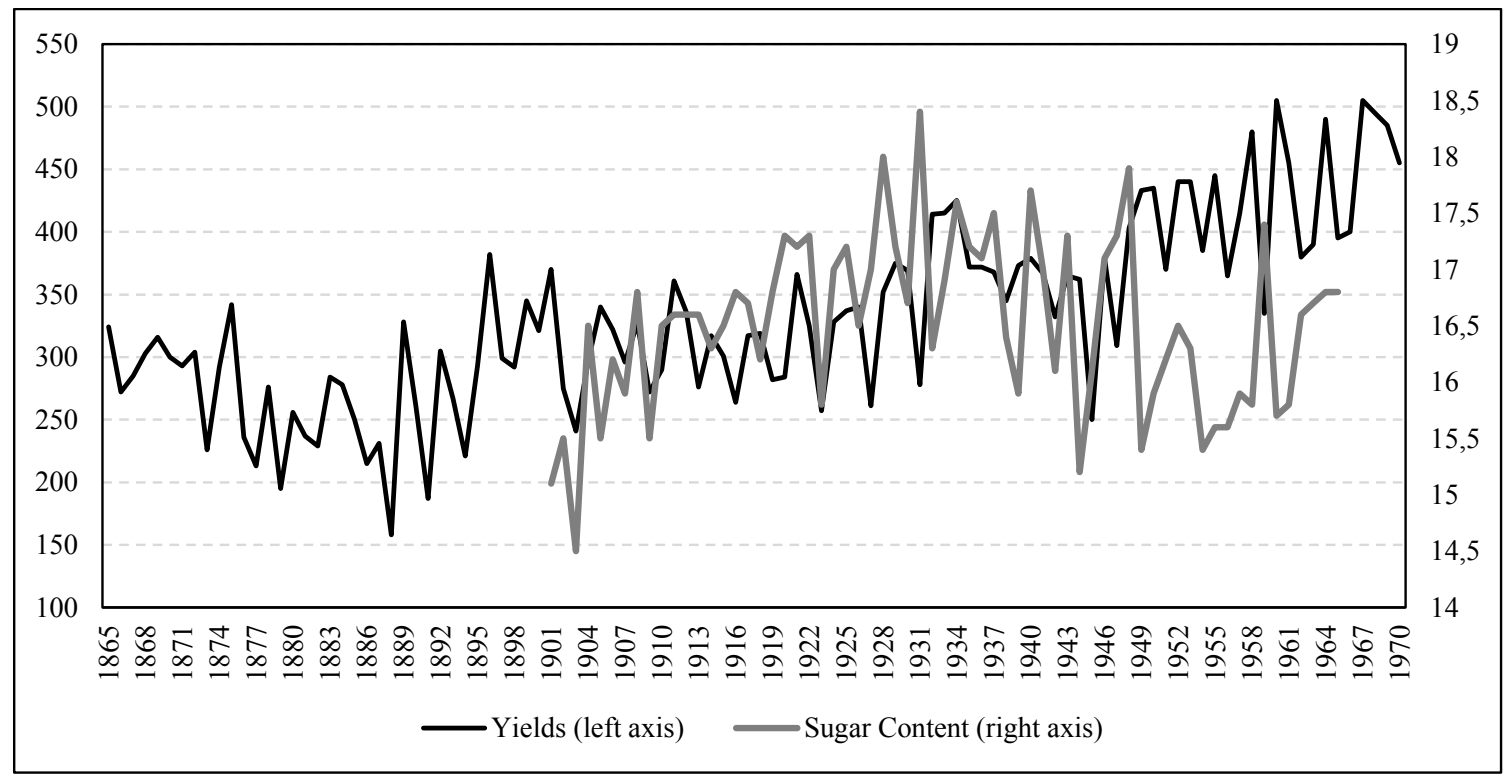

Source: Yields from 200 jaar statistiek in tijdreeksen (CBS 2000), 31. Sugar content (in yearly averages) from Terlouw, 'De geschiedenis van de bietsuikerindustrie in Nederland', 200-201.

It should be noted first that the sugar beet cooperatives had an increasingly far-reaching range.

Lacking reliable membership records, the combined membership of the sugar beet cooperatives can only be estimated. In 1899 the first sugar beet cooperative started with 173 members only, but by 1920 the seven sugar beet cooperatives together had about 7,000 members and in the late 1940s they had about 9,000 members. ${ }^{31}$ These were relative large numbers relative to the estimates of the total number of arable farmers, as we will now see.

\footnotetext{
${ }^{31}$ The estimates are based on the known membership of five sugar beet cooperatives plus an educated guess for the two other sugar beet cooperatives. In 1920, the five cooperatives with known membership had $1,772+932+1,065+1,737+465=5,993$ members. The last two cooperatives were smaller than the largest four cooperatives, but larger than the smallest cooperative. The membership of these last two cooperatives have been (conservatively) estimated to be c. 500 member each. At the end of the $1940 \mathrm{~s}$, three of the four cooperatives together had 5,282 members. Taking into account that a) the other large cooperative probably also had c. 1,500 members; b) the two smaller cooperatives had c. 1,000 members; c) one cooperative was dissolved in 1929, the estimated membership in the late 1940s was about 9,000. Terlouw, "De geschiedenis van de bietsuikerindustrie in Nederland en van de Coöperatieve Suikerfabriek en Raffinaderij g.a. Puttershoek 1912-1966 in het bijzonder met inachtneming van de overheidspolitiek en de verhouding tussen de coöperatieve en de particuliere industrie," 208; Brabants Historisch Informatie Centrum (hereafter BHIC), entry nr. 181 Archief Suikerfabriek Dinteloord, Zevenbergen, Roosendaal, 1908-1968 (hereafter SDZR), inv. nr. 360, Statistiek betalingen aan aandeelhouders fabriek, 1909-1950; BHIC, SDZR, inv. nr. 40, Exploitatierekening, 1918-1949; Groninger Archieven (hereafter GA), entry nr. 1435 archief Friesch-Groningsche Coöperatieve Beetwortelsuikerfabriek, 1913-1970 (hereafter FGCB), inv. nr. 1139, 'Algemene statistiek'. Register met gegevens over kosten, opbrengsten en ledenaantallen,
} 
Consider the following estimation. According to the agricultural census of 1921 there were 13,414 farmers in the south-western part of the Netherlands, where sugar beet cultivation by then was concentrated. ${ }^{32}$ Given that the sugar beet cooperatives in the south-western part of the Netherlands (so excluding the Friesch-Groningsche cooperative in the north) together had an estimated membership of 5,228 in 1920, it can be assumed that the sugar beet cooperatives had a considerable outreach - particularly when taking into account that the number of 13,414 farmers includes farmers not producing sugar beets, as the 1921 census did not distinguish between arable and dairy farmers. ${ }^{33}$ The growing membership of the sugar beet cooperatives seems to have mirrored the overall increase in sugar beet cultivation. The growth in membership slowed down in the 1930s and 1940s, but increased again significantly after the Second World War. When the sugar beet cooperatives merged into one cooperative to form the Suiker Unie ('Sugar Union') in 1970, they jointly had no less than 15,000 members. ${ }^{34}$

How did the Dutch sugar beet cooperatives contribute to agricultural innovation? The first part of the two-fold answer to this question lies in the internal organisation of the cooperatives. The cooperatives granted their members access to inputs. Within a sugar beet cooperative, farmers partly regained their previously lost agency. Though having to comply to certain standards, the members enjoyed a considerable degree of freedom to use the varieties, fertilizers, and cultivation methods they deemed best. The regelementen ('regulations') of the cooperatives only stipulated that the board had the authority to reject sugar beet deliveries with a sugar content below $14 \%$, when the sugar beets were or had been frozen, when the sugar beets

1914-1951; ZA, ENCBS, inv. nr. 38, Ingekomen en minuten van uitgaande stukken, 1900-1935. Surendonk, Groei uit suiker. Oorsprong en ontwikkeling van Coöperatie Cosun U.A. (1899-1999), 7.

${ }^{32}$ The figure of 13,414 farmers is the sum of the number of farmers in the following regions: 1) Hoeksche Waard, 2) Voorne, Putten en Rozenburg, 3) Goeree en Overflakkee (all in the province of Zuid-Holland), 4) Noordwestelijke zeekleigronden (in the province of Noord-Brabant), and the entire province of Zeeland. See Het Grondgebruik in Nederland in 1921, Verslagen en Mededeelingen van de Directie van den Landbouw 2 (The Hague, 1923), 52-53.

${ }^{33}$ The figure of 5,228 members in 1920 is calculated by taking my estimate of the full 1920 membership of 7,000 members and deducting the members of the Friesch-Groningsche cooperative $(1,772)$.

${ }^{34}$ Surendonk, Groei uit suiker. Oorsprong en ontwikkeling van Coöperatie Cosun U.A. (1899-1999), 7. 
were rotten, and when the member had cultivated varieties not permitted by the board. ${ }^{35}$ The members could not cultivate any variety they deemed fit, as the board preselected three to seven varieties. The board preselected those varieties which had proven their reliability in previous seasons and which met the quality standards of the cooperative. Per share a fixed amount of seeds could be ordered for free or against reduced charges. Circulars were distributed among the members between early December and late February, asking which of the preselected varieties they wanted to order. ${ }^{36}$

While giving their members options to innovate, the cooperatives seem to have rarely if at all - obliged the use of certain inputs or innovations. The members of the cooperatives were granted a degree of freedom they did not receive from the private industry. This freedom did not always work out favourably. The cooperatives were often confronted with substandard beets, particularly in their early years of existence. ${ }^{37}$ In 1905, for instance, the Sas van Gent cooperative had to deal with internal troubles. Some members complained that other members had sold their high-quality sugar beets to a private factory against high prices while dumping lesser-quality sugar beets at the cooperative. Some of these fraudulent members even ordered cheaper and substandard sugar beets from other farmers to meet the requirements of their share. This free-riding behaviour, it was agreed upon, jeopardized the proper functioning of the cooperative and should thus be avoided. A majority of members recognized the need for quality

\footnotetext{
${ }^{35}$ See article 16 in the Reglementen of the Zevenbergen sugar beet cooperative. BHIC, SDZR, inv. nr. 91, Statuten en Reglementen 1916-1960.

${ }^{36}$ If the members would not pass on their preference before the deadline, usually in March or April, the board of the cooperative would simply select seeds for them. Many distributed circulars with seed selections have been preserved in the archival records of the sugar beet cooperatives in Puttershoek and Dinteloord. See Regionaal Archief Dordrecht (hereafter RAD), entry nr. 746, Suiker Unie te Puttershoek en haar rechtsvoorgangers (hereafter SUP), inv. nrs. 55, 56, 57, 58 and 247 for circulars from 1915 to 1954. See also BHIC, SDZR, inv. nr. 368, circulaires 1934-1939.

${ }^{37}$ In 1903, for instance, one member of the Sas van Gent cooperative, who was installed as inspector to oversee the deliveries by other members, rejected entire deliveries for the (presumed) unusual shape of the beets. Other inspecting members, this inspector complained, would always simply accept all delivered sugar beets, regardless of shape and quality, which, according to this inspector, harmed the sugar production process of the cooperative's factory - and ultimately the cooperative itself. ZA, ENCBS, inv. nr. 1, 'Notulen der Algemeene Vergaderingen, 19 Oct. 1899 - 5 Febr. 1903', 71.
} 
standards and product uniformity and valued the freedom of the individual members while acknowledging that this freedom needed to be checked. ${ }^{38}$

The cooperatives had various methods to maintain their standards. Apart from issuing fines, the cooperatives could 'name and shame' those breaking the rules. Meetings of shareholders were occasionally opened by reading aloud a list of members who had received penalties. ${ }^{39}$ Additionally, when the quality of the beets of one particular farmer gradually declined over the years, this farmer would be addressed in private and would be asked to consider changing his farming methods, for instance by using other cultivation methods or other inputs. Networks of inspectors (usually members themselves) kept the boards of the cooperatives well informed about the members. The records of the Sas van Gent cooperative contain a membership list, presumably circulating among the board members, with notes scribbled in the side-lines. While it was said of one member that his land was contaminated with a contagious disease, other members were accused of providing beets to the private industry, of being 'a less skilled farmer', of 'being always in opposition', or were simply described as a 'dolt' or 'queer little man'. ${ }^{40}$ A close eye was kept on the members, particularly on their farming abilities. In short, the internal organisation of the sugar beet cooperatives was based on mutual trust. Members were granted access to inputs and received a degree of flexibility to apply these inputs in the quantities and in the manner they thought best - individual farmers themselves were thought to be the experts on their fields - but those violating this confidence by purposefully delivering substandard sugar beets were filtered out and punished.

The mutual trust within the cooperatives also came with a degree of peer pressure. Members of the cooperatives were encouraged by the board, or encouraged each other, to improve their farming methods. This was done, first of all, by helping members to deal with the

\footnotetext{
${ }^{38}$ ZA, ENCBS, inv. nr. 2, 'Notulen der Algemeene Vergaderingen, 6 Aug. 1903 - 23 Juli 1919’, 20.

${ }^{39}$ ZA, ENCBS, inv. nr. 2, 'Notulen der Algemeene Vergaderingen, 6 Aug. 1903 - 23 juli 1919', 6-7.

40 'besmet met bietenaaltjes', 'levert ook nog aan CSM', 'minder goede boer', 'is altijd in de oppositie', 'sukkel', 'apart manneke', quotations from ZA, ENCBS, entry nr. 39, Correspondentie 1935-1943.
} 
problems they were confronted with. Problems were discussed during the meetings of shareholders, but a more effective way to improve the resilience of members was by distributing pamphlets. In 1929 the Puttershoek cooperative gave detailed instructions on how to apply the chemical Kiezelfluornatrium to exterminate the beet fly (Pegomya betae) and in 1938 on how to use soap and methylated spirit to exterminate blackflies. ${ }^{41}$ In the late 1920 s the Dinteloord cooperative distributed various pamphlets about how and in what quantities to use the chemical Germisan to disinfect seeds. ${ }^{42}$

While the cooperatives had provided information on various varieties in earlier years, after the Second World War the presented knowledge became more detailed, structured, and reliable. Since 1950 the circulars that had to be filled in to order seeds contained results of experimental fields (divided between the south and the north of the country) and gave information on root yield, sugar content, 'grubbingness' (rooibaarheid), foliage growth, and resistance against diseases and bolters. The circulars advised which varieties to use in which time of the season (early, middle, or late) and in which regions, as the circulars divided the Netherlands in the north, the southern sea-clay regions, the sandy regions, and the polders. Since 1953 the circulars also gave information on which varieties could be used in seeding machines, which were divided into 'normal' seeding machines and 'precision' seeding machines. $^{43}$

The sugar beet cooperatives contributed to the innovation capacity of their members through their internal organisation. The cooperatives, firstly, had a high degree of exclusivity. Members of the sugar beet cooperative had to make themselves identifiable, had to sign legal contracts, and had to comply to certain access rules (for instance owning enough capital to purchase a share and producing enough to deliver a certain amount of beets every year). This

\footnotetext{
${ }^{41}$ RAD, SUP, inv. nrs. 55, circulars from 1915 to 1935, circular from 1929.

${ }^{42}$ SDZR, 367A, Circulaires 1901-1931.

${ }^{43}$ RAD, SUP, inv. nrs. 57, 58, and 247, circulars from 1943 to 1954.
} 
exclusivity resulted in a high degree of reciprocity. Secondly, the sugar beet cooperatives were self-regulating. Although the day-to-day activities within the sugar factories were often done by employees, the policy of the cooperative, including disciplinary matters, was the responsibility of the board, which consisted of members elected by the meeting of shareholders. Although some members were no doubt more influential than others, the governance structure of the cooperatives was in principal based on egalitarian and democratic values. Thirdly, both the self-regulating and exclusive character resulted in a strong communal identity. The archival material of the sugar beet cooperatives show that such a communal identity, in the form of the cooperative ideal, was very much present among the members. When in 1920 the board of the Friesch-Groningsche cooperative proposed to build a new sugar factory in collaboration with two private sugar companies, one member immediately declined this idea. 'We started the battle against speculation,' he stated, 'should we now get into a comparable monopoly? We should keep the essence and character of cooperation in our society as pure as possible'. Another member exclaimed that he saw nothing in a 'marriage between Cooperation and Speculation', asking the rhetorical question how a cooperative could have ever come up with such an idea. ${ }^{44}$ The sugar beet cooperatives, so it was perceived, were set up for and by farmers to prevent industrial capitalists enriching themselves at the expense of the individual farmer.

Fourthly, the sugar beet cooperatives solved local problems. Although the sugar beet cooperatives collaborated with each other on the national level and had supralocal issues to solve, they had partly originated in the desire to dispose of the one-size-fits-all approach of the private industry. Rather than imposing the use of certain inputs, the cooperatives acknowledged the location-specific nature of arable farming. The internal organisation of the sugar beet

\footnotetext{
44 'Wij zijn deze strijd tegen de speculatie begonnen, en zullen wij thans een zelfde monopolie gaan binnenhalen? (...) Wij moeten het wezen en het karakter in onze Vereniging liefst zo zuiver mogelijk houden'. 'Zo op het eerste gezicht voelt spreker heel weinig voor het aangaan van een huwelijk tussen Coöperatie en Speculatie' (...) 'hoe kan een coöperatie als deze er toekomen, haar richting prijs te geven; haar plaats instede te versterken te verzwakken?' Quotations from GA, FGCB, inv. nr. 1, Notulen van de algemene ledenvergadering. Afschriften, 1913-1923, page 3 of the meeting on September 16, 1920.
} 
cooperatives, in sum, facilitated the diffusion of knowledge, aided the individual farmer when having to make complicated choices, and stimulated him to improve his farming.

\subsection{Sugar beet cooperatives' collaboration on the national level}

Apart from their internal organization, the sugar beet cooperatives also contributed to agricultural innovation through their collaboration on the national level. The sugar beet cooperatives jointly organized $\mathrm{R} \& \mathrm{D}$, which originated in the quest for improved varieties. For long, most sugar beet varieties in the Netherlands were imported from Germany, which was the world leader in sugar beet breeding. ${ }^{45}$ This became a reason for concern when the influx of German seeds diminished during the First World War. With international markets inaccessible, the Dutch sugar beet cooperatives were handed over to the domestic market, consequently becoming heavily dependent on one Dutch breeding company in particular, Kuhn \& Co.

The Dutch sugar beet cooperatives had a difficult relationship with Kuhn \& Co. Without a strong domestic competitor for this company, the cooperatives had a weak bargaining position and had to submit themselves to unfavourable contracts. The seeds delivered by Kuhn \& Co did not always satisfy. Members of the Friesch-Groningsche cooperative, for instance, complained about the Kuhn variety repeatedly and urged the cooperative, to no avail, to breed its own variety. The cooperative was tied to a multiple-year contract with Kuhn - a contract presumably signed during or shortly after the First World War and still mentioned in the cooperative's minutes in 1926 ! - and the board of the cooperative countered criticism from its

\footnotetext{
${ }^{45}$ The total production of German sugar beet seeds in the early 1910s has been estimated at 90,000 tonnes annually, of which approximately 57,000 tonnes were exported. Jonathan Harwood, Europe's Green Revolution and Others Since. The Rise and Fall of Peasant-Friendly Plant Breeding, Routledge Explorations in Economic History 56 (London and New York: Routledge, 2012), 37. Perkins, "The Agricultural Revolution in Germany 1850-1914," 115. Thomas Wieland, "Wir beherrschen den pflanzlichen Organismus besser,..." Wissenschaftiche Pflanzenzüchtung in Deutschland 1889-1945, Abhandlungen und Berichte, Neue Folge 20 (München: Deutsches Museum, 2004), 31.
} 
members by arguing that the results of the Kuhn variety on testing fields elsewhere in the Netherlands were not unsatisfactory. ${ }^{46}$

Yet, complaints about the Kuhn variety were not confined to the north. During a heated discussion at the Puttershoek cooperative in 1921 many members complained about the poor quality of the Kuhn variety. One speaker, surprisingly, stood up for the company and dismissed all criticism. The chairman of the cooperative reacted that it was commonly known that commercial breeders occasionally got in contact with members to speak in favour of their company - suggesting that the earlier speaker was instructed (and possibly paid) by Kuhn \& Co to defend their interests within the cooperative. ${ }^{47}$ The discomfort with Kuhn's monopoly even caused the Dinteloord cooperative to try to avoid the Kuhn variety entirely. In March 1917 the board assured its members that it searched international markets for varieties from smaller commercial breeders in Germany - German seeds were on their way, the board exclaimed almost relieved. Even though it was unclear when the delivery was to be expected, which varieties it would consist of, or from which breeders the seeds would actually come, the simple fact that the varieties were German - and not Kuhn's - was apparently enough reassurance. ${ }^{48}$

The problems with the supply of seeds from the international markets, the monopoly of Kuhn \& Co on the Dutch domestic market, and the disappointing quality of the Kuhn variety caused the Dutch sugar beet cooperatives to join forces. In the early 1920s a small Dutch breeding company, the Nederlandsche Elitezaad Maatschappij ('Dutch Elite Seed Company', hereafter NEM) got into financial difficulty and requested a loan from the sugar beet cooperatives. When representatives of the cooperatives came together to discuss this issue, it was recalled how 'dangerous' it was when 'Germany had abandoned' the cooperatives during

\footnotetext{
${ }^{46}$ GA, FGCB, inv. nr. 1, Notulen van de algemene ledenvergadering. Afschriften 1913-1923, page 3 and 4 of the minutes of June 24, 1919; pages 3 and 4 of the minutes of June 29, 1920; page 10 of the minutes of September 27, 1922; inv. nr. 2, Notulen van de algemene ledenvergadering. Afschriften 1924-1935, page 4 of the minutes of September 7, 1926.

${ }^{47}$ RAD, SUP, inv. nr. 11, Notulen 1912-1926, page 164.

${ }^{48}$ BHIC, SDZR, inv. nr. 367A, circulaires 1909-1931, circulaire 27 maart 1917.
} 
the First World War and when the cooperatives were 'handed over to Kuhn'. ${ }^{49}$ A competitive Dutch breeding company besides Kuhn \& Co was asked for, as there was need for 'two seed companies, so that we are not fully dependent on foreign countries ${ }^{5}{ }^{50}$ Because it was deemed important, 'with regard to Germany', to 'have a competitor on the market' [for Kuhn, HZ], it was decided that NEM was to be supported. ${ }^{51}$

Wanting to avoid low-quality varieties, the Dutch sugar beet cooperatives installed a committee to investigate the quality and reliability of NEM. 'The issue with NEM', this committee stated, 'has made clear that there is a great need for scientific, reliable experimental fields for sugar beets' [emphasis in the original, HZ]. Without experimental fields, the quality of NEM varieties, or any variety for that matter, could not be easily determined. 'Would it not be possible', the committee thus concluded, 'to form one organization to manage these experimental fields? ${ }^{52}$ These words proved to be prophetic when the cooperatives formed the Bond van Coöperatieve Suikerfabrieken in Nederland ('Association for cooperative sugar factories in the Netherlands'). ${ }^{53}$

The Association organized its research through the Proefvelden Commissie ('Committee on Experimental Fields'). This committee administered a number of experimental fields and was in contact with public agricultural consultants and with scientists at the State Agricultural

\footnotetext{
49 'Dhr Kakebeek wijst op het feit, hoe gevaarlijk het was, toen Duitschland ons in den steek liet, geheel aan Kuhn overgeleverd geweest te zijn', quote from ZA, ENCBS, entry nr. 81, Geldleningen Nederlandse Elitezaad Maatschappij, minutes of a meeting on February 2, 1924.

50 'Ook deze spreker betoogt de wenschelijkheid van het bestaan in Nederland van twee zaadfirma's, opdat wij niet geheel van het buitenland zouden afhangen'. Quote from GA, FGCB, entry nr. 355, Notulen van de Bond van Coöperatieve Suikerfabrieken, 1926-1934, minutes of a meeting on November 24, 1927.

51 'Ook met het oog op Duitschland moet men trachten een concurrent op de markt te houden. De Voorzitter ondersteunt dit en zegt, dat wij, door zaad te bestellen, dan ook vermoedelijk onze eigen zaak dienen'. Quote from a copy of a meeting of representatives of all sugar beet cooperatives on February 13, 1924. See ZA, ENCBS, entry nr. 81, Geldleningen Nederlandse Elitezaad Maatschappij.

52 'Bij deze kwestie is nog eens duidelijk gebleken de groote behoefte die er bestaat aan wetenschappelijk gedreven betrouwbare varieteitsproefvelden voor suikerbieten. Indien die er waren zou de waarde die aan N.E.M. zaad gehecht moet worden veel beter te beoordelen zijn. (...) Zou het niet mogelijk zijn een organisatie te vormen vanwege de gezamenlijke suikerfabrikanten om tot zulke proefvelden te komen?' Quote from ZA, ENCBS, entry nr. 38, Correspondentie 1900-1935. Letter on November 22, 1923.

${ }^{53}$ Although it is unclear when exactly the Association was established, its earliest minutes start in 1926. Copies of these minutes are found in the archival records of the Friesch-Groningsche cooperative. See GA, FGCB, entry nr. 355, Notulen van de Bond van Coöperatieve Suikerfabrieken, 1926-1934 and entry nr. 356, Notulen van de Bond van Coöperatieve Suikerfabrieken, 1935-1942.
} 
College in Wageningen. Its ultimate goal, however, was to determine which varieties were reliable on which types of soils. ${ }^{54}$ In 1930 the research activities of the Association and its Committee on Experimental Fields were taken over by the Instituut voor Rationele Suikerproductie ('Institute for Rational Sugar Production') at Bergen op Zoom, established in 1930. Financed by the six sugar beet cooperatives and one private sugar company, the Institute dealt with fertilizing, plant breeding, mechanization, and plant diseases. ${ }^{55}$ The Institute especially aimed at reducing regional variation. In 1938 the Friesch-Groningsche cooperative mentioned that, due to the Institute's efforts, the differences between yields in the north and yields in the south, a serious concern for this northern, had finally started declining. ${ }^{56}$ The Institute also adapted foreign inputs (seeds and fertilizers in particular) to the specific Dutch ecological characteristics. It was noted during a meeting of the Institute's board that German sugar beet varieties reached higher yields in Germany than in the Netherlands, 'from which it can be concluded that in the Netherlands we need other seeds than in Germany'. ${ }^{57}$ Through research and development the Dutch sugar beet cooperatives hoped to be less dependent on imported knowledge and innovation.

The Institute distributed its information to the members of the sugar beet cooperatives. Scientific progress, the board of the Institute emphasized repeatedly, was not an end in itself: the Institute was to generate knowledge useful for the members of the cooperatives. ${ }^{58}$ Results from experiments were distributed among the members to grant more background information

\footnotetext{
${ }^{54}$ For the activities of the Association, as well as various experiments done under its supervision, see its minutes in GA, FGCB, entry nr. 355, Notulen van de Bond van Coöperatieve Suikerfabrieken, 1926-1934.

${ }_{55}$ Willem Heijbroek and Jurgen Maassen, eds., Zoete invallen. 75 jaar onderzoek en voorlichting voor de Nederlandse suikerbietenteelt (Bergen op Zoom: Stichting IRS, 2005).

56 'Wat de bietenbouw betreft meent Uw Bestuur te kunnen constateren, dat vooral tengevolge van het werk van de Groninger Bietencommissie en het Instituut voor Suikerbietenteelt gevestigd te Bergen op Zoom, het grote verschil in opbrengst tussen het Zuiden en het Noorden geleidelijk kleiner begint te worden.' Quote from GA, FGCB, inv. nr. 3, Notulen algemene ledenvergadering, 1936-1948. Page 1 of the meeting on September 13, 1938. 57 ‘... waaruit geconcludeerd kan worden, dat voor Nederland ander zaad nodig is dan voor Duitschland.' Quote from GA, FGCB, inv. nr. 357, Correspondentie van de Bond van Coöperatieve Suikerfabrieken, 1920-1925. Copy from the minutes of a meeting on February 23, 1938.

${ }^{58}$ GA, FGCB, inv. nr. 355, Notulen van de Bond van Coöperatieve Suikerfabrieken, 1926-1934. See especially the meeting on March 8, 1933.
} 
on the reliability of various varieties, a recurring point of discussion within the cooperatives. ${ }^{59}$ The Institute used the networks of the cooperatives to reach individual farmers, sending a small journal - 'the Sugar Beet' - to all the members of the cooperatives. The Institute itself also became a link in a larger, nation-wide network of knowledge-diffusing and innovationproducing actors. Various private fertilizer companies, including the German $I G$ Farben, the Dutch Chili Handelsmaatschappij, and the Dutch Kali Handelsmaatschappij, paid the Institute to study the effects of their artificial fertilizers on sugar beet cultivation and to distribute the results, positive or negative, among the members of the cooperatives. ${ }^{60}$ Since its establishment in 1930 the Institute had developed into the central authority on Dutch sugar beet cultivation.

The last contribution of the sugar beet cooperatives to agricultural innovation is the ability of the cooperatives to integrate smaller farmers into their organization. Due to a lack of source material, it can only be assumed that the early members of the cooperatives were large farmers. Consider the following calculation. When established in 1912, the Puttershoek cooperative had 468 members who jointly owned 2,041 shares, which means 4.36 shares on average per member. Per share one had to deliver between 20,000 and 30,000 kilograms of beets annually, so at least between 87,200 and 130,800 kilograms per member. ${ }^{61}$ Given that in 1912 the average yield per hectare was 33,600 kilograms, a member of the Puttershoek cooperative in 1912 would hypothetically have to reserve between 2.6 and 3.9 hectares to meet

\footnotetext{
59 'De heer Veenstra deelt mede, dat de wensch om zelf de zaadkeuze te bepalen bij de bietentelers aanwezig is. (...) De heer Smit merkt op, dat men het verband tusschen telers en fabriek uit het oog verliest. Het is niet mogelijk, den telers toe te staan zelf op willekeurige wijze hun zaadkeuze te bepalen. Dit zou tot schade zoowel van telers als van de fabrieken leiden. Overigens hebben de telers de keuze tusschen 3 of 4 beste rassen. Er volgen discussies. Tenslotte wordt besloten, dat een overzicht over 5 jaar zal worden samengesteld. Dit zal aan de leden ter beoordeeling worden toegezonden.' Quote from GA, FGCB, inv. nr. 357, Correspondentie van de Bond van Coöperatieve Suikerfabrieken. Page 5 of a copy of the minutes of a meeting on March 11, 1936.

60 'De Chili Handel Mij deed aan het Instituut het verzoek om proeven te nemen met chilisalpeter ter bestrijding van gebreksziekten bij bieten. Deze proeven zouden geheel door het Instituut genomen moeten worden, waartegenover de Chili Mij een zekere bijdrage zou verleenen, terwijl de resultaten van het onderzoek volgens het oorspronkelijke plan door het Instituut zouden worden gepubliceerd. Ongeveer eenzelfde verzoek werd gedaan door de IG Farbenindustrie (...). Ook de Kali Mij kwam met een soortgelijk verzoek.' GA, FGCB, entry nr. 357, Correspondentie van de Bond, 1920-1925. Copy of the Minutes of the Institute's board on March 11, 1936.

${ }^{61}$ This information was found in the bond loan the Puttershoek cooperative issued in 1912. See RAD, SUP, inv. nr. 235.
} 
the requirements of his shares. ${ }^{62}$ Though not a strikingly large portion of land at first glance, it is unlikely that a farmer would grow sugar beets on all his plots - he would spread the risk by also growing potatoes and grains and would reserve some of his plots to feed his draft animals. From this it can be reasoned that the first generation of members of the Puttershoek cooperative, or of any of the sugar beet cooperatives, were certainly not small farmers.

Sugar beet cultivation in the Netherlands took off in the south-eastern sea clay regions. Graph 5.3 and Map 5.2. shows that, prior to the Second World War, the centre of sugar beet cultivation was Zeeland, followed by neighbouring regions in Zuid-Holland (particularly the southern part of this province) and in Noord-Brabant (particularly the western sea-clay area) and the northern sea clay regions in Groningen and Friesland. After the Second World War, however, sugar beet cultivation increased continuously in Limburg and Drenthe, where sugar beet cultivation had previously been rare, and in the newly-reclaimed polder regions, which were only colonized in the 1940s and 1950s. Once cultivated mainly on the sea-clay regions, sugar beets had now become an important crop on other soil types as well. Dutch sugar beet cultivation thus became more evenly distributed among the various Dutch regions.

${ }^{62}$ The 1912 average yield comes from 200 jaar statistiek in tijdreeksen (CBS 2000), 31. 


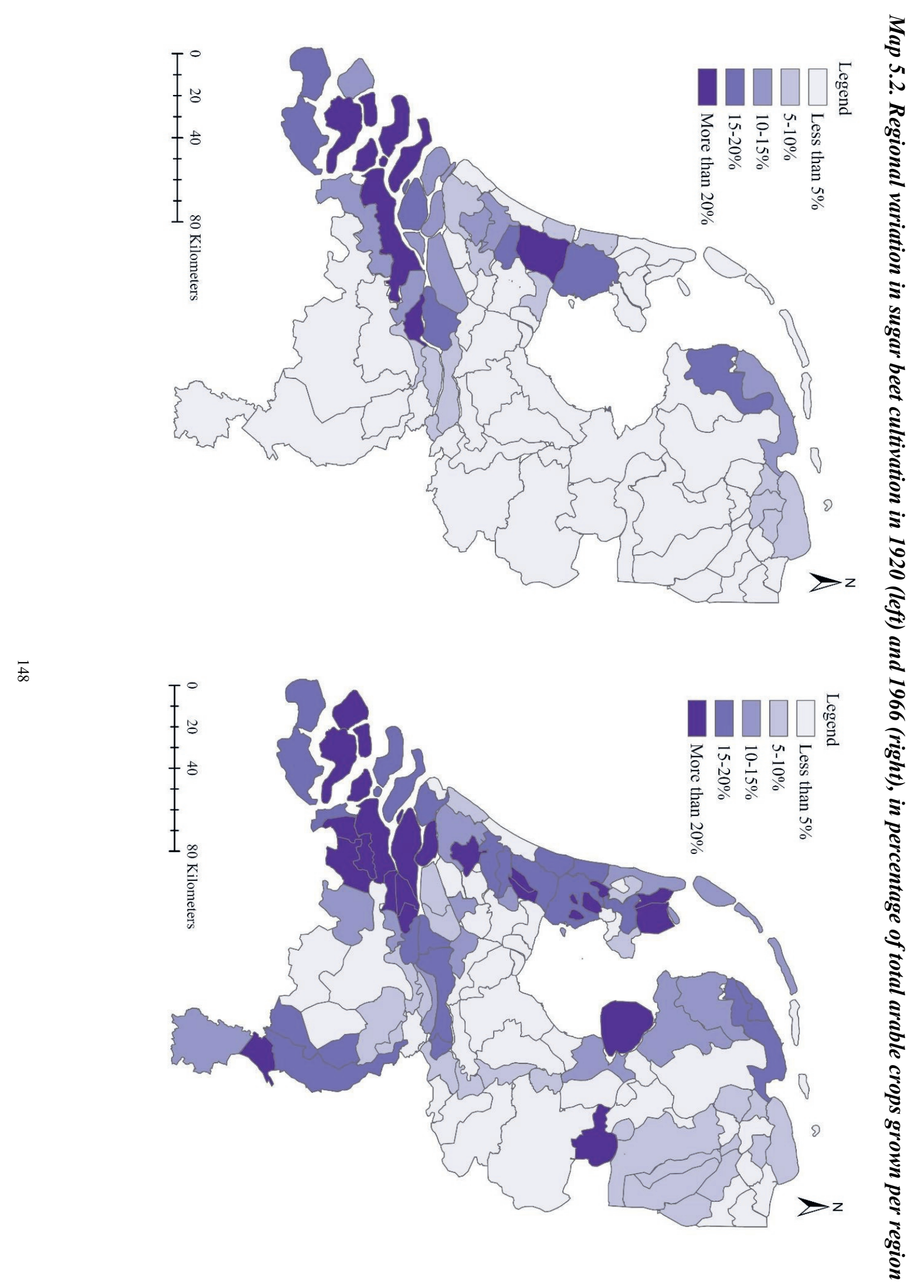


Graph 5.3. Sugar beet acreages in seven areas, 1903-1966 (in hectares).

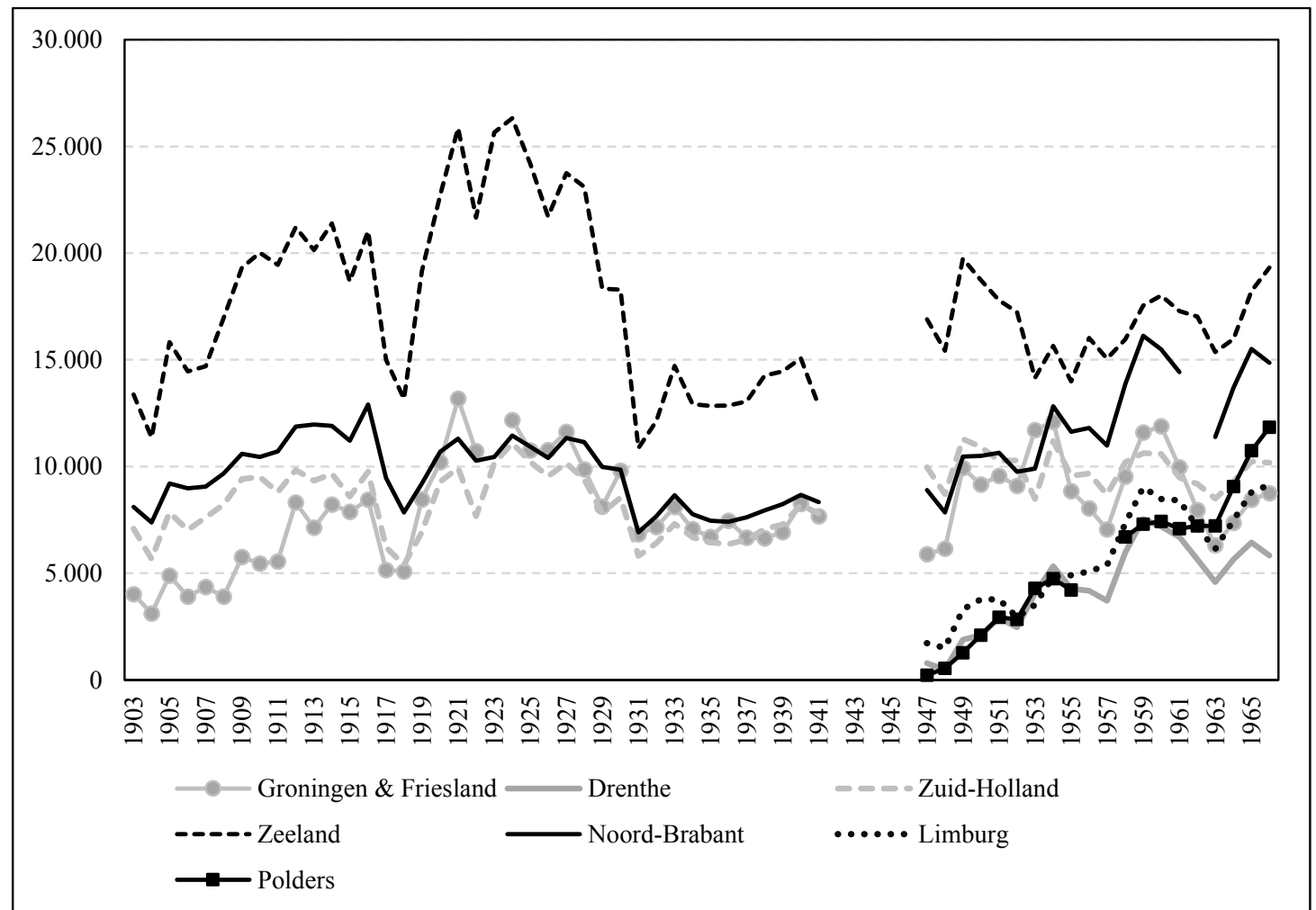

Source: Verslagen van den Landbouw, 1903-1966. The graph does not include Noord-Holland, Gelderland, Utrecht, and Overijssel. The polders are the Noordoostpolder and the Flevopolder.

Many of the 'new' sugar beet farmers in the regions where sugar beet cultivation was relatively new were small farmers, and thus did not grow enough sugar beets to individually meet the requirements that came with a share of a cooperative. They could not become members in their own right. They instead united themselves in societies which were also organized according to the cooperative principle. In 1947, sugar beet farmers in Limburg formed the Coöperatieve Vereniging voor de Afzet van Suikerbieten (Cooperative Society for the Marketing of Sugar Beets), shortly COVAS. In that same year, farmers in the recently reclaimed Noordoostpolder united themselves in the Coöperatieve Suikerbietentelersvereniging 'Beta' (Cooperative Sugar Beet Cultivators Society 'Beta'). Lastly, in 1953 farmers in the eastern part of the NoordBrabant province formed the Coöperatieve Suikerbietentelersvereniging (Cooperatives Sugar Beet Cultivators Society), shortly CVS. The members of COVAS jointly bought shares of the 
Roosendaal, Dinteloord, and Zevenbergen cooperatives, while the 'Beta' cooperative became a member of the Roosendaal, Dinteloord, Zevenbergen, Friesch-Groningsche, and Sas van Gent cooperatives. The CVS from eastern Noord-Brabant joined the Roosendaal, Dinteloord, and Zevenbergen cooperatives. ${ }^{63}$

With this system - cooperatives joining cooperatives - the sugar beet cooperatives extended their range and increased their output, which was important to stay competitive internationally. This system also gave advantages to the many smaller farmers who were unable to join sugar beet cooperatives before the Second World War. The contributions to agricultural innovation - the knowledge networks, the peer pressure to meet certain quality standards, etc. - were now available to smaller farmers without having to comply to various financial demands, such as buying a share and committing to the yearly delivery of a certain amount of beets. As the first steps in cooperation and innovation, including the risks involved, had been taken by (presumably larger) farmers in the southeast and the north, now (presumably smaller) farmers from elsewhere could join to take advantage of the improved infrastructure.

The integration of farmers from the other parts of the Netherlands coincided with a scaling up. The sugar beet cooperatives in Roosendaal, Dinteloord, and Zevenbergen, all three located in the western part of Noord-Brabant, merged into one cooperative, the Verenigde Coöperatieve Suikerfabrieken (United Cooperative Sugar Factories, hereafter VCS) in 1947. ${ }^{64}$ In the meantime the Dutch sugar industry formed various consultative bodies in which the sugar beet cooperatives collaborated on a national level for marketing and political lobbying. In the early 1950s the sugar beet cooperatives, together with a private factory, opened the Veevoeder Bureau van de Nederlandse Suikerindustrie ('Fodder Bureau of the Dutch Sugar Industry') which marketed the fibrous pulp used as cattle feed. After the establishment of the European

\footnotetext{
${ }^{63}$ Surendonk, Groei uit suiker. Oorsprong en ontwikkeling van Coöperatie Cosun U.A. (1899-1999), 50-51.

${ }^{64}$ Terlouw, "De geschiedenis van de bietsuikerindustrie in Nederland en van de Coöperatieve Suikerfabriek en Raffinaderij g.a. Puttershoek 1912-1966 in het bijzonder met inachtneming van de overheidspolitiek en de verhouding tussen de coöperatieve en de particuliere industrie," 63-64.
} 
Economic Community in 1958 the sugar beet cooperatives and other stakeholders from the Dutch sugar industry also formed the Suikerraad ('Sugar Council'), which was to present the interests of the Dutch sugar industry in Europe. ${ }^{65}$ The collaboration between the sugar beet cooperatives eventually culminated in a full merger. In 1966 the VCS, the Puttershoek cooperative, the Sas van Gent cooperative, and the Friesch-Groningsche cooperative together formed one overarching cooperative, in which each cooperative had one vote. A few years later, in 1970, the sugar beet cooperatives were dissolved entirely and its members jointly formed one cooperative, the Suiker Unie (Sugar Union).

This scaling up drastically changed the cooperative organization of Dutch sugar beet production. Some of the unique characteristics of the sugar beet cooperatives were lost. With 15,000 members, individual farmers had limited influence on the policy of the Suiker Unie and presumably felt less personally and emotionally attached. Also the peer pressure and the local character of the cooperatives, once the strength of the cooperatives, were largely lost. The contributions of the sugar beet cooperatives to agricultural innovation might have started diminishing with this scaling up.

\subsection{Conclusion}

Since the end of the nineteenth century Dutch arable farmers saw themselves integrated into a dense network of different actors diffusing knowledge and generating innovation. A large part of this network, the previous chapter has shown, was orchestrated top-down: public agricultural consultants organized public lectures, managed experimental fields, gave individual advice to farmers, and set up agricultural education. However, these components of the knowledge networks lacked certain qualities that only marketing cooperatives had. Agricultural consultants and other actors could provide knowledge and assistance, but it was up to the individual farmer

\footnotetext{
${ }^{65}$ Surendonk, Groei uit suiker. Oorsprong en ontwikkeling van Coöperatie Cosun U.A. (1899-1999), 53.
} 
how to respond. Without regulation, this transfer of knowledge depended on the power of persuasion of the agricultural consultants and on the receptivity and willingness of the individual farmer. Within marketing cooperatives other forces were at play: as part of a larger group with a common goal, members were under peer pressure to use the knowledge, assistance, and innovations that the cooperatives provided.

The case of the Dutch sugar beet cooperatives has shown that marketing cooperatives were organized in such a way that members (re)gained power over inputs, which they had previously lost to the private industry, and that members were allowed a considerable degree of freedom, though in exchange for certain quality standards. As such, Dutch marketing cooperatives balanced between the need of the individual farmer and need of the cooperative at large, a tension the private industry was not willing - or not able - to solve. Despite the individual freedom, members were encouraged to improve the quality of their products and the fertility of their fields. This was done through a dense but nation-wide network that accumulated specialized knowledge on matters related to sugar beet cultivation, backed by investments in plant breeding and R\&D. While the sugar beet cooperatives as well as this nation-wide network had been established by large farmers, smaller farmers became part of the sugar beet cooperatives in later decades, now integrating into the organization and the networks once the risk had declined.

Because anything close to a counterfactual is lacking, it remains unclear how Dutch arable farming would have developed without marketing cooperatives. What this chapter has shown, however, is that the Dutch marketing cooperatives added a sense of community - a community with common goals, solidarity, and group pressure - to agricultural innovation that other (public) agents could not. The Dutch marketing cooperatives were certainly not stagnant entities protecting the status-quo. Instead, they actively sought for improvement and helped 
their members to deal with market changes, increasing international competition, and new technology - in short, arming farmers to earn a livelihood in a constantly changing context. 


\section{CHAPTER VI}

\section{GREENHOUSE HORTICULTURE AND DUTCH AGRICULTURAL CREDIT \\ INFRASTRUCTURE}

\subsection{Introduction}

The foregoing chapters have shown how an expanding public-private institutional network, including public actors and agricultural cooperatives, facilitated the capital-intensive growth that was required for Dutch farmers to grasp new market opportunities, which followed from globalization and international market integration. This capital-intensive growth of Dutch agriculture found its pinnacle in greenhouse horticulture. ${ }^{1}$ During the twentieth century the Netherlands experienced what has been referred to as a 'Greenhouse Revolution': Dutch greenhouse acreage increased from merely 46 hectares in 1904 to no less than 6,287 hectares in $1966 .^{2}$ This tremendous growth occurred in two periods (see Graph 6.1). First, greenhouse acreage increased tenfold between the First World War and the mid-1930s. Second, after growth in greenhouse acreage had stabilized since the 1930s and had even turned into a decline during the closing years of the Second World War, since 1951 greenhouse hectares again increased almost every year, leading to a threefold growth until the late 1960s. Given that this growth in greenhouse acreage occurred before gas reserves in the northern Netherlands were exploited in the late 1960s, the Dutch greenhouse revolution cannot be attributed to cheap fossil fuels, as might be assumed. Although the Dutch greenhouse sector certainly profited from cheap Dutch gas, the growth in greenhouse acreage has other origins.

\footnotetext{
${ }^{1}$ Throughout this chapter greenhouse horticulture refers to the cultivation of vegetables, fruits, and flowers in greenhouses. In literature, greenhouses are sometimes also known as glasshouses or hothouses (when heated). Greenhouses are structures of translucent material, usually glass, in which various environmental variables, particularly heat, humidity, and light, can be regulated.

2 The term 'Greenhouse Revolution' comes from Julian Nicholson, The Dutch Glasshouse Industry. An Economic History (Wye: Wye College Press, 1995), 31.
} 
The growth in Dutch greenhouse acreage is all the more striking when taking into account that around 1900 Dutch greenhouse horticulture was still small compared to equivalent sectors in Britain, Belgium, or the United States, where greenhouse horticulture originated. By the mid-twentieth century, however, the greenhouse horticultural sector in the Netherlands was the largest in size, as one-fourth of all world greenhouse horticultural area was located in the Netherlands. The spectacular growth in Dutch greenhouse acreage during the first half of the twentieth century coincided with rapid technological advancement, with Dutch farmers searching for the optimum greenhouse to improve control over temperature, precipitation, light, and other variables. Within decades, the Dutch greenhouse horticulture sector had not only become the largest, but also arguably the most knowledge-intensive of its kind.

Graph 6.1. Dutch area of hotbeds and greenhouses, 1895-1966 (in hectares)

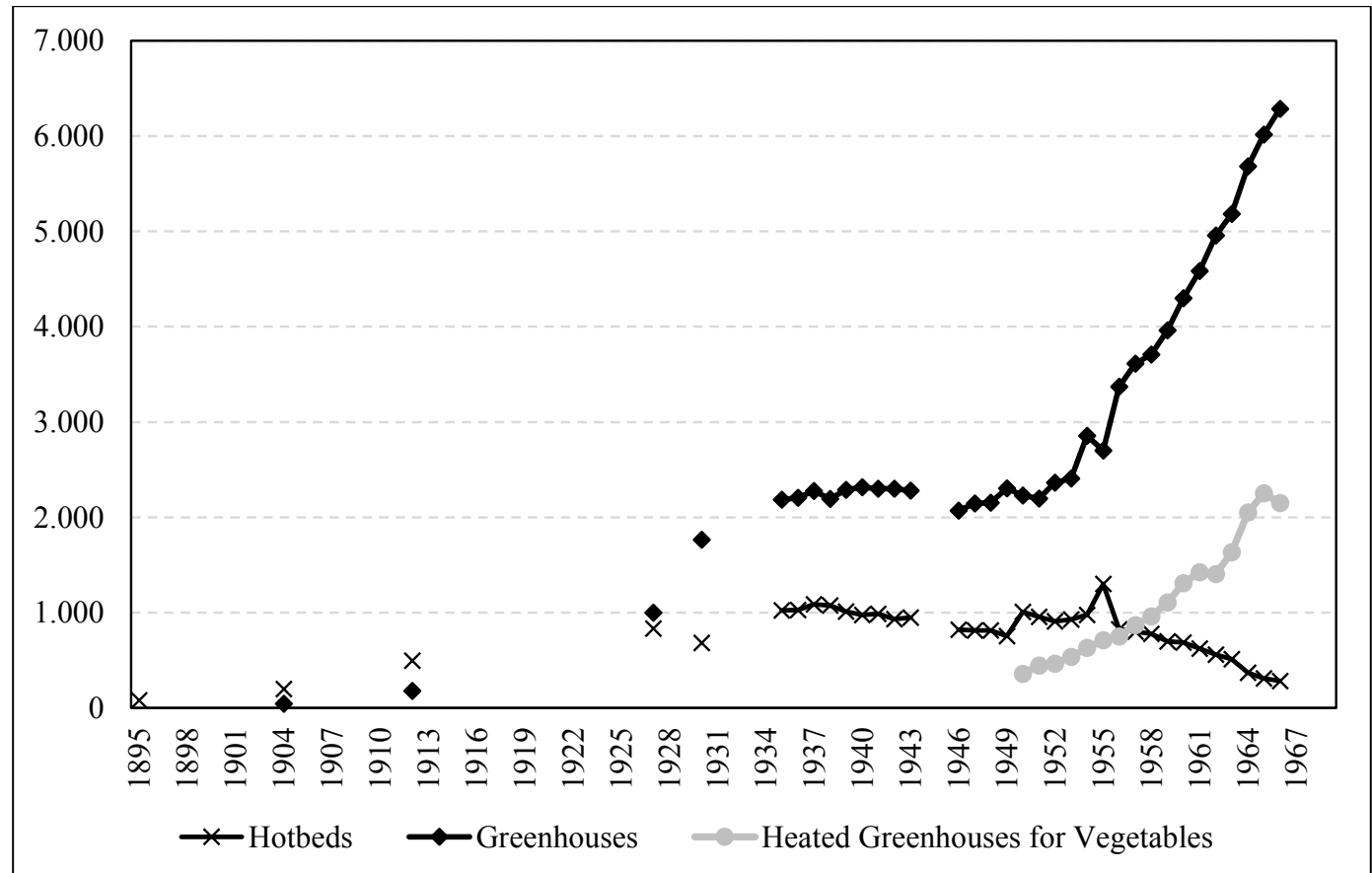

Source: Sangers, De ontwikkeling van de Nederlandse tuinbouw (tot het jaar 1930), 234; Beschrijving van den Tuinbouw in Nederland, Verslagen en Mededeelingen van de Directie van den Landbouw (1906); Verslag der in 1912 gehouden tuinbouwtelling (1913); Tuinbouwtelling 1927, Jaarboek van het Centraal Bureau van de Veilingen in Nederland (1927); Grondgebruik in Nederland in 1930 (1935), 29; Verslagen van den Landbouw, 1937-1967. 
The Dutch greenhouse revolution has not yet been sufficiently explained. ${ }^{3}$ This chapter aims to improve our understanding of the development of Dutch greenhouse horticulture by closely tracking market developments and institutional changes during the 1910s and the 1920s and during the 1950s and the 1960s, the two periods of rapid growth as observed in Graph 6.1. Particular attention will be given to credit and marketing institutions. While sharing many characteristics with other subsectors of agriculture, greenhouse horticulture also has two main features setting it apart. Firstly, horticultural products are more perishable than most arable products. As a result, the marketing in horticultural products was determined by the speed at which horticultural products could be shipped from farmer to customer. With a system of cooperative auctions, this chapter argues, the Dutch greenhouse sector had found a way to organize the trade in perishable goods. Secondly, the building and the maintenance of the glass and wooden or iron constructions of which greenhouses consist as well as the heating machines, the sprinklers, and other specific greenhouse technology made greenhouse horticulture considerably more dependent on cash flows than non-greenhouse agriculture. As a result, the success of greenhouse horticulture largely depended on access to credit and on the ability of greenhouse farmers to rapidly reinvest cash earned on international markets.

With this in mind, this chapter attributes the Dutch greenhouse revolution, firstly, to the system of cooperative auctions, which, though not credit institutes by their very nature, granted their farming members cash to be reinvested, and, secondly, to the well-functioning credit infrastructure which was facilitated by both private and government initiative, particularly since

\footnotetext{
${ }^{3}$ Despite its economic success, the history of Dutch greenhouse horticulture has received limited scholarly attention. Besides anniversary books, regional histories, publications on the technological improvements of greenhouses, and popularizing books on the international fame of Dutch greenhouses by the end of the twentieth century, an academic study on the socioeconomic history of Dutch greenhouse horticulture is lacking. An exception is the short study of Nicholson. He compares Dutch greenhouse horticulture with its British equivalent, but focuses on the period after the 1970s: Nicholson, The Dutch Glasshouse Industry. An Economic History. This lacuna in historiography is presumably due to a lack of archival sources; archival records of cooperative auctions from the early twentieth century have gone missing after the many post-Second World War mergers, while also the archives of Dutch research institutes related to greenhouse horticulture contain very limited pre-Second World War material.
} 
the 1950s. The Dutch greenhouse revolution can also hardly be imagined without an expanding knowledge system. A geographically-dense network, highly concentrated within the core greenhouse horticultural region, consisted of companies, research stations, consultancy centres, and study clubs that together contributed to a swift knowledge exchange.

The forces at play in Dutch greenhouse horticulture were not unlike what we have observed for the entire Dutch arable sector in the foregoing chapters: the high level of Dutch farmers' self-organization, expressed most clearly in the establishment of agricultural cooperatives, in combination with government stimulation of agricultural $\mathrm{R} \& \mathrm{D}$, aided the Dutch agricultural sector to profit wholly from the insatiable food demand in neighbouring countries. Dutch greenhouse horticulture, this chapter argues, also conjured out of the possibilities that the close location to the Von Thünen-like centre of the European market granted - possibilities that would not have been easily grasped without a transformed institutional landscape. As we have seen in chapter two, horticultural export volumes, though still small compared to livestock and arable export, had the largest growth rates. The export of vegetables, fruits, and flowers increased no less than twenty-fold between 1860 and $1925 .{ }^{4}$ Before we will sketch the role of cooperative auctions and credit institutions in capitalizing the profits made from this enormous horticultural export, the following section shortly narrates the historical development of the Dutch greenhouse horticultural sector and places it in an international perspective.

\subsection{The development of Dutch greenhouse horticulture}

For long greenhouses were rare in Europe. In the early modern period, princely courts and botanic gardens used orangeries to grow exotic plants, fruits, and flowers, not rarely as a display

\footnotetext{
${ }^{4}$ These figures, it should be noted, also contain horticultural crops not grown in greenhouses. Dirk Pilat, Dutch Agricultural Export Performance (1846-1926), Historia Agriculturae 19 (Groningen: Nederlands AgronomischHistorisch Instituut, 1989), 68-78.
} 
of grandeur and prestige. Eighteenth-century urban elites occasionally built (heated) greenhouses at their country residences to enjoy the luxury of a garden flowering out of season. The most famous greenhouse was the Crystal Palace, a 360 meter long, 137 meter wide, and 7.28 hectare covering glass and iron construction which housed the Great Exhibition of 1851 in London. Before the nineteenth century the function of most greenhouses was largely recreational. $^{5}$

The usage of glass constructions for commercial agricultural production originated in the United States in the early nineteenth century. Hotbeds, which are low glass constructions, were used to protect vegetables from wind, precipitation, and cold. Later, hotbeds were often lifted and turned into greenhouses to enable grape production in unfavourable climatic conditions. In 1900, a quarter of world greenhouse horticultural area (including hotbeds) was to be found in the US. Of these 1,000 hectares of glass, mainly found close to urban centres on the East Coast and in the Midwest, 90\% consisted of greenhouses, while the usage of hotbeds declined. A comparable development pattern can be observed in Europe: the usage of hotbeds to improve the production of high-value crops (usually in or close to urbanized regions) was followed by a shift to greenhouses, often for grape production. The main European greenhouse concentrations were located around the Channel and the North Sea: greenhouses were used on the Channel Island of Guernsey to produce grapes since the 1830 s and, since the 1880 s, to produce tomatoes. Since the 1860 s greenhouses were also built around London to produce grapes and, later, also tomatoes and cucumbers, which culminated to 200 hectares of greenhouses by 1900. In Belgium the production of grapes in greenhouses started in the hinterland of Brussels in 1868, increasing to 180 hectares by 1910 and 240 hectares by $1924 .{ }^{6}$

\footnotetext{
${ }^{5}$ For an extensive and detailed history of greenhouses prior to the nineteenth century, see the first four chapters of Erwin W.B. van den Muijzenberg, A History of Greenhouses (Wageningen: Institute for Agricultural Engineering, 1980).

${ }^{6}$ Nicholson, The Dutch Glasshouse Industry. An Economic History, 17-18.
} 
In the Netherlands the usage of glass constructions in agricultural production started and concentrated in the Westland region, the triangle between The Hague, Rotterdam, and the North Sea coastline. With its proximity to many of the Holland towns and its fertile soils - clay topped with sand from the nearby dunes - this region had become a centre of fruit and vegetable production as early as the seventeenth century. The Westland region was characterized by a high concentration of estates owned by abbeys or urban elites. These estates often consisted of orchards producing high-value products, such as ornamentals or specific uncommon vegetables. $^{7}$

In the early nineteenth century many of these orchards were transformed into small plots where farmers earned a living by producing grapes, peaches, apples, plums, and pears. Producing goods more suitable for warmer climates for wealthy consumers in English and Dutch towns, these small farmers in the Westland region were part of a highly competitive market and thus had to operate on the technological and agronomic frontier of their day. For example, an important Westland crop were 'early potatoes', which were germinated in a warm place during winter (often inside) to be planted in February and harvested in June, when they could receive a higher price on the English market. Between 1859 and 1869 potato area in the Westland region tripled, and in specific parts of the Westland region it even increased with 450 percent from 1852 to $1878 .^{8}$

The expediting of crop cultivation to get higher prices earlier in the season, called 'forcing' (forceren), was also the main reason behind the introduction of hotbeds. Referred to in Dutch as broeiramen ('brewing windows'), éénruiters ('single window glasses') or platglas

\footnotetext{
${ }^{7}$ It has been argued that the presence of these estates set the example for the common Westland farmer and pushed the Westland horticultural sector to higher levels; the estates were sometimes sold to local farmers and the labourers at these estates profited from their acquired know-how when starting their own businesses. Jan Barendse, Hollands tuin. De Westlandse tuinbouw van vroeger tot nu ('s-Gravenzande: Drukkerij A. Sonneveld, 1951), 4963. W.J. Sangers, De ontwikkeling van de Nederlandse tuinbouw (tot het jaar 1930) (Zwolle: Tjeenk Willink, 1952), 158-59.

${ }^{8}$ Frans Groot, Roomsen, rechtzinnigen en nieuwlichters. Verzuiling in een Hollandse plattelandsgemeente, Naaldwijk 1850-1930 (Hilversum: Verloren, 1992), 25-31. Jan van Doesburg et al., eds., Honderd jaar praktijkonderzoek voor de glastuinbouw. Meten = weten (Doetinchem: Elsevier, 1999), 15-16.
} 
('flat glass'), hotbeds were used to protect strawberries, spinach, lettuce, radish, cucumbers, cauliflower, and tomatoes from birds, wind, precipitation, and cold. ${ }^{9}$ Presumably already used in flower production in earlier years, the first hotbeds used for vegetable cultivation was seen in 1872 , although the wider diffusion of hotbeds occurred mainly during the $1880 \mathrm{~s} .{ }^{10}$

Another telling example of how international competition spurred the technology of Westland farmers is grape production. By 1878 , there were 18 kilometres of 'grape walls' (druivenmuren) in the Westland region, as grapes were often grown against brick walls. ${ }^{11}$ Since 1885 glass constructions were built diagonally against these grape walls to stop the wind, retain sun warmth, and grant the opportunity to produce higher-quality grapes earlier in the season. The need to further improve grape cultivation also led to the introduction of greenhouses. The first Dutch greenhouse for grape cultivation was built in the Westland region in 1888 , allegedly by a farmer who had first visited grape greenhouses near Brussels. The advantage of greenhouses was that the brick walls previously used for grape cultivation were no longer needed, which meant that more grape plants could be grown on a given area of land. Moreover, in greenhouses the cultivation of grapes could be combined with vegetable cultivation, while temperature could be better managed and more accurate care could be given to soil and plant treatment, which both had been notoriously labour intensive in hotbeds. ${ }^{12}$ Graph 6.1. above shows that hotbeds were still more widely used than greenhouses until at least the 1910s. By 1927, however, hectares used for greenhouses had surpassed hotbed hectares. Hotbed acreage stabilized at around 1,000 hectares hereafter, to drop heavily (in absolute terms as well as relative to greenhouses) after the late 1950s.

\footnotetext{
${ }^{9}$ Barendse, Hollands tuin. De Westlandse tuinbouw van vroeger tot $n u, 138-39$.

${ }^{10}$ A.J. Vijverberg, Glastuinbouw in ontwikkeling. Beschouwingen over de sector en de beïnloeding ervan door de wetenschap (Delft: Eburon, 1996), 55-57.

${ }^{11}$ Of these 18 kilometres, six were in the village of Naaldwijk, in the centre of the Westland. Sangers, De ontwikkeling van de Nederlandse tuinbouw (tot het jaar 1930), 188.

${ }^{12}$ The harsh winter of 1903 was allegedly a stimulus to turn from hotbeds to greenhouses, as heavy snowfall covered the hotbeds, consequently ruining the fertilizer used in the hotbeds and eventually leading to crop failure. Vijverberg, Glastuinbouw in ontwikkeling. Beschouwingen over de sector en de beïnloeding ervan door de wetenschap, 57.
} 
Whereas the growth in hotbed acreage had stagnated during the mid-1920s, the usage of greenhouses meanwhile increased, from 46 hectares in 1904 to a peak of 1,088 hectares in 1937, to drop back to around 800 hectares in the late 1940s (see Graph 6.1). Comparing Dutch greenhouse horticulture with its equivalent in Guernsey, another European centre of greenhouse horticulture, Nicholson notes that Guernsey greenhouse horticulture was largely financed by entrepreneurs who reinvested profits earned in trading and shipbuilding; greenhouses in Guernsey were thus not rarely company-owned. ${ }^{13}$ While the Guernsey greenhouses were often made of iron, Westland farmers, usually with less resources, developed greenhouse constructions that were relatively cheap in purchase and maintenance. The greenhouse type used in the Westland, which became known internationally as 'Dutch light glasshouses' or 'Dutch frames' and referred to in the Netherlands as 'Westland warenhuizen', consisted of simple wooden constructions, with glass that could be easily taken off to be used for hotbeds. ${ }^{14}$ This multifunctional use and the relatively cheap wooden construction of the Westland greenhouse type increased its popularity and contributed to the swift diffusion of greenhouse horticulture during the Interbellum and during the 1950s and 1960s (see Map 6.1. and 6.2). Close to the Westland, just northeast of Rotterdam, a second greenhouse centre emerged: together with the Westland, this De Kring region became known as the South Holland glass district. Although Dutch greenhouse acreage also increased in other Dutch regions - most notably around Venlo at the south-eastern border and around Aalsmeer, south of Amsterdam and highly specialized in bulb and flower production - the South Holland glass district remained the core. Sometimes colloquially referred to as 'Holland's Garden' or 'the City of Glass', the South Holland glass district, and the Westland region in particular, has often been the synonym, as a pars pro toto, of the entire Dutch greenhouse horticultural sector.

\footnotetext{
${ }^{13}$ Nicholson, The Dutch Glasshouse Industry. An Economic History, 20.

14 Van den Muijzenberg, A History of Greenhouses, 223. Vijverberg, Glastuinbouw in ontwikkeling. Beschouwingen over de sector en de beïnloeding ervan door de wetenschap, 57.
} 


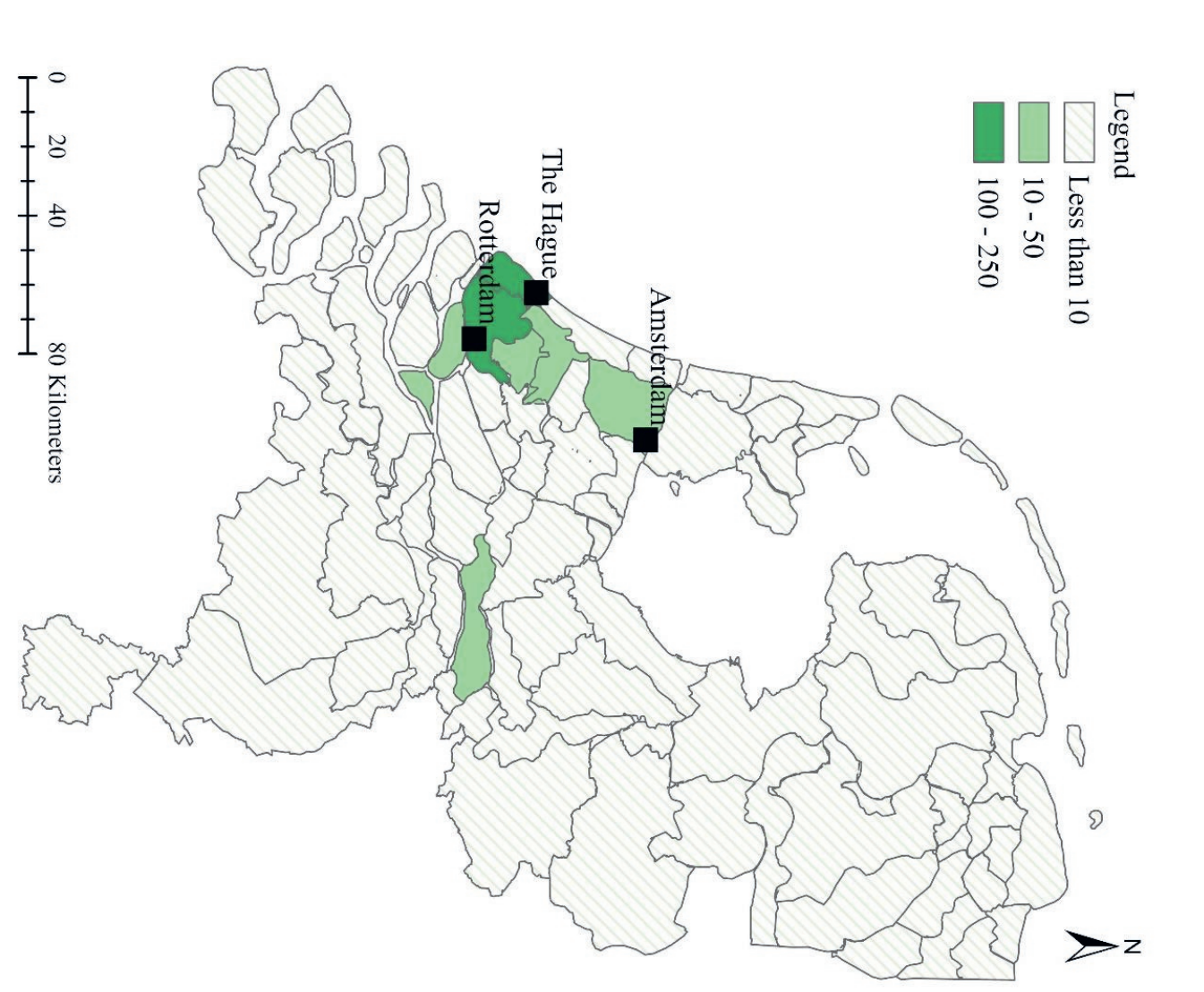

可

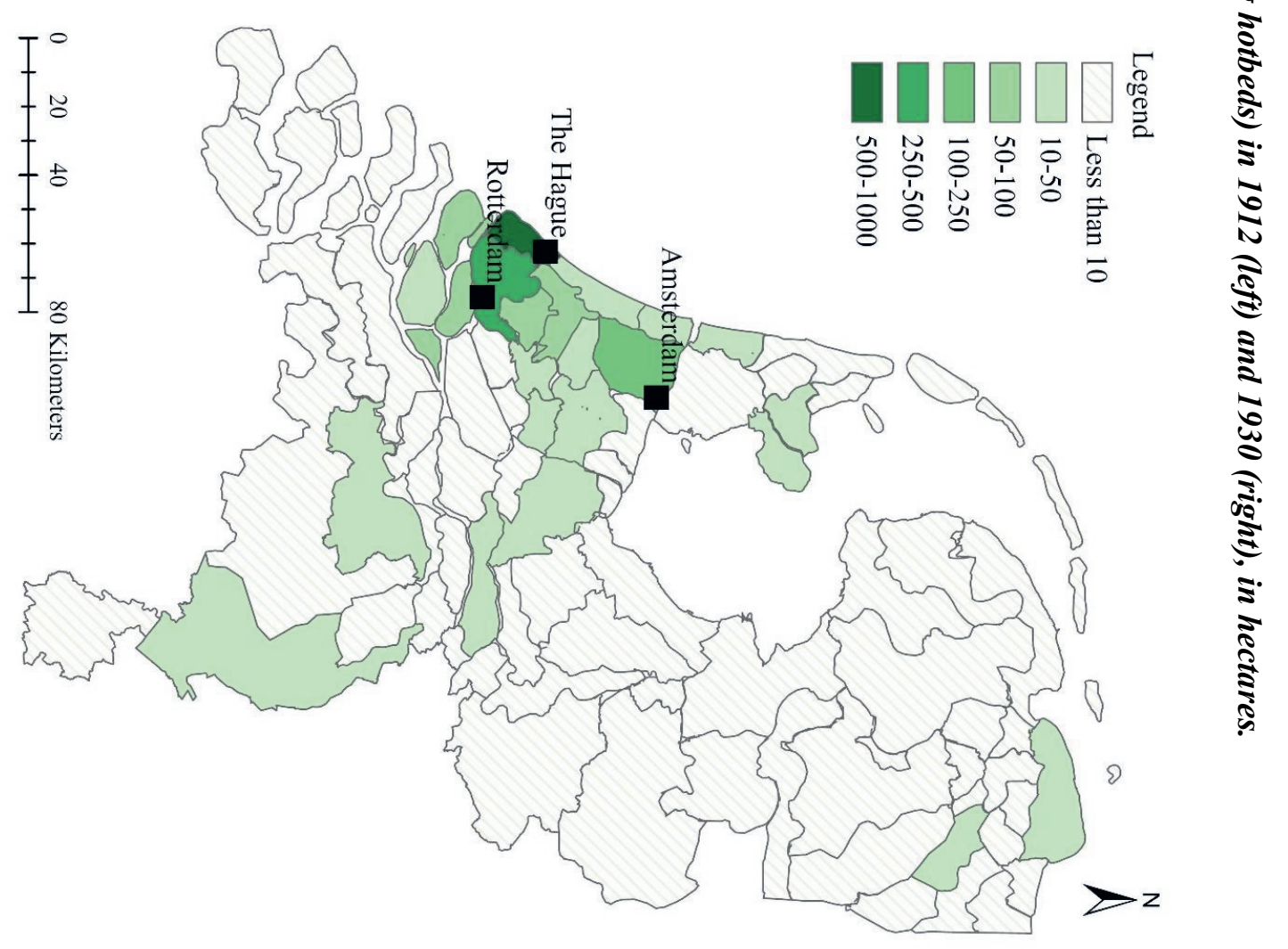



hectares

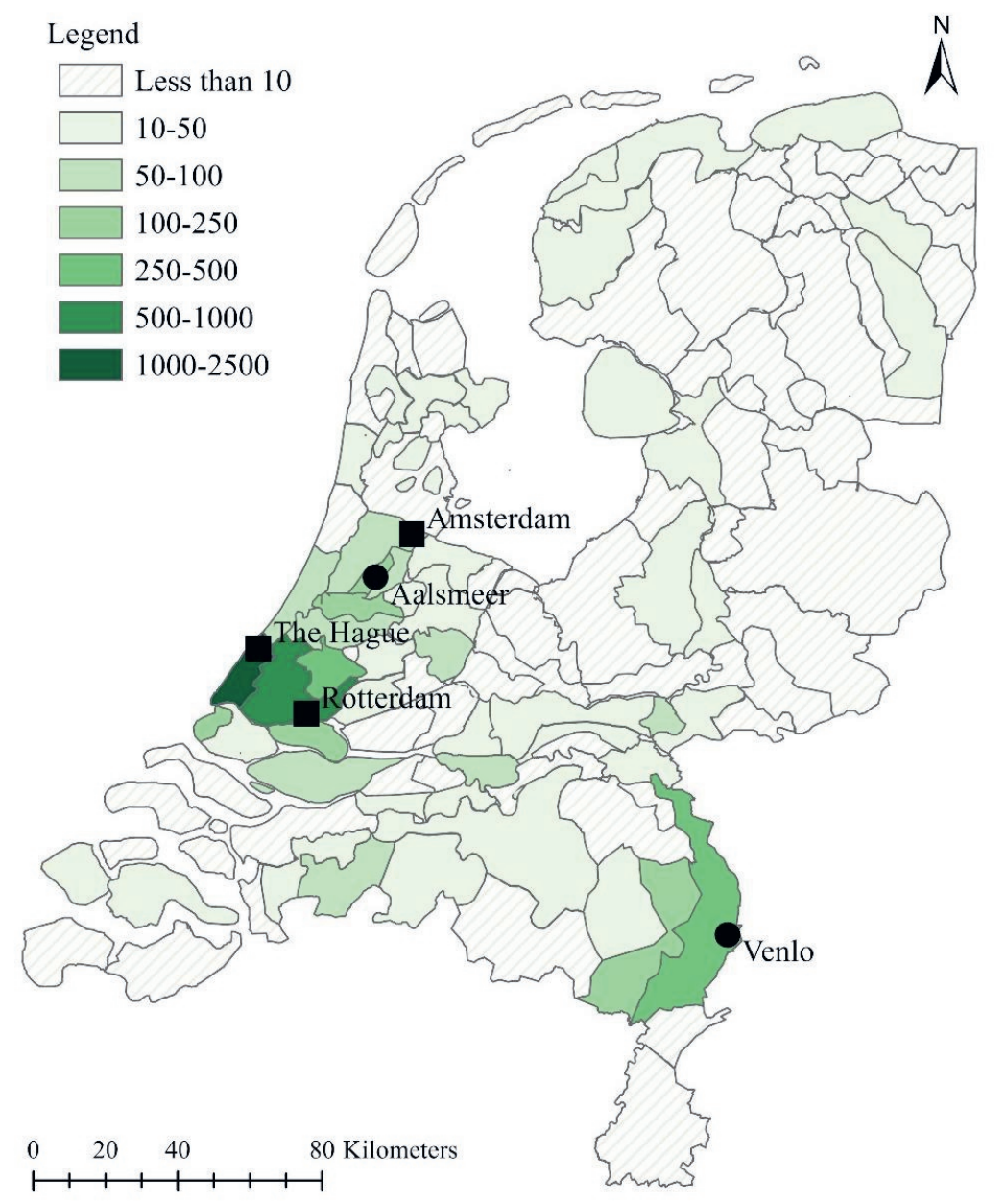

Greenhouse farmers in the South Holland glass district took the lead in the technological advancement of heating their greenhouses. Anecdotal evidence suggests that Westland farmers had started heating their greenhouses by at least the 1920s. Water was heated in boilers by burning coal, after which the steam and heated water circulated through iron pipes. This technique presumably diffused swiftly, as coal transports from the port of Rotterdam to the Westland region increased from 38,000 tons in 1926 to 143,000 tons in $1929 .{ }^{15}$ The heating

\footnotetext{
${ }^{15}$ Van den Muijzenberg, A History of Greenhouses, 223. Nicholson, The Dutch Glasshouse Industry. An Economic History, 34 .
} 
issue, as well as the need to reduce construction and maintenance costs, drove an ongoing search for the optimum greenhouse and resulted in the popularity of the Westland greenhouse type to shift to the newer Venlo kas. First introduced in the south-eastern town of Venlo in 1937, this greenhouse type was constructed from iron instead of wood, had a higher sun light transmission, and had fewer cracks, which made temperature management more efficient. The Venlo type became particularly popular after the Second World War and was the main Dutch greenhouse type during the rapid growth of the sector during the 1950s and the $1960 \mathrm{~s} .{ }^{16}$ Besides the introduction of the Venlo greenhouse, the heating of greenhouses also became more efficient with the introduction of heat pumps in the 1950s. With these heat pumps, less water, smaller boilers, and narrower pipes were needed. The post-war growth of the Rotterdam fossil fuel industry simultaneously reduced energy costs and caused coal to be substituted by oil in the 1960s and by gas in the 1970s. ${ }^{17}$ The acreage of heated greenhouses used for vegetable cultivation, Graph 6.1 has shown, increased from 356 hectares in 1950 (16\% of total Dutch greenhouse area) to 2,150 hectares in 1966 (35\% of total Dutch greenhouse area). These proportions, it should be noted, only include greenhouses heated for vegetable cultivation and are thus presumably lower-bound estimates; also greenhouses used for fruit or flower cultivation were often heated.

\footnotetext{
${ }^{16}$ Vijverberg, Glastuinbouw in ontwikkeling. Beschouwingen over de sector en de bë̈vloeding ervan door de wetenschap, 58-59.

${ }^{17}$ Van den Muijzenberg, A History of Greenhouses, 223. Nicholson, The Dutch Glasshouse Industry. An Economic History, 34.
} 
Table 6.1. World greenhouse horticultural area (in hectares), c. 1900, 1950 and 1970

\begin{tabular}{lrr|rr|rr}
\hline Country & Year & Hectares & \multicolumn{2}{r|}{ Year } & Hectares & \multicolumn{2}{r}{ Year } & Hectares \\
the Netherlands & 1904 & 46 & 1950 & 3,251 & 1970 & 7,238 \\
South Holland Glass District & & & 1952 & 2,404 & 1970 & 3,978 \\
England & 1900 & 200 & 1946 & 1,900 & 1970 & 2,363 \\
Belgium & 1910 & 180 & 1949 & 759 & 1970 & 1,232 \\
USSR & & & 1949 & 900 & 1970 & 2,166 \\
France & & & 1949 & 200 & 1970 & 1,200 \\
Germany & & 1949 & 989 & 1970 & 861 \\
Denmark & & 1949 & 350 & 1970 & 570 \\
\hline Europe total & & & $\mathbf{9 , 4 6 9}$ & & $\mathbf{2 3 , 5 0 0}$ \\
USA & 1900 & 900 & 1949 & 2,051 & 1970 & 2,105 \\
\hline World total & & & & c. $\mathbf{1 2 , 0 0 0}$ & & c. $\mathbf{2 6 , 8 0 0}$
\end{tabular}

Source: Erwin W.B. van den Muijzenberg, A History of Greenhouses (Wageningen: Institute for Agricultural Engineering, 1980), 285; A.F. Bosma, S. van Veen, and H.J.M. Vis, De ontwikkeling van de tuinbouwvestiging in het Zuidhollands Glasdistrict, LEI Studies 17 (The Hague: Landbouw-Economisch Instituut, 1965), 14; Julian Nicholson, The Dutch Glasshouse Industry. An Economic History (Wye: Wye College Press 1995), 41 and G.G. van Leeuwen, Tuinarbeid in het Zuidhollands Glasdistrict. Een onderzoek naar de arbeidsvoorziening in de tuinbouw in het Westland en de Kring, LEI Studies 299 (The Hague: Landbouw-Economisch Instituut, 1977),78. Note: the 200 hectares of greenhouses in England in 1900 does not include greenhouse acreage on Guernsey, the English figures for 1946 and 1970 do.

The swift diffusion of the Westland greenhouse type and, later, the Venlo greenhouse type contributed to the truly revolutionary growth of Dutch greenhouse horticulture. Whereas greenhouse horticulture had initially originated in the United States, by the mid-twentieth century it was clearly a Western European phenomenon. In fact, as revealed in Table 6.1, by 1950 one-fourth of all world greenhouse horticulture area was concentrated in the Netherlands, and about $20 \%$ in the South Holland glass district specifically. Although the size of the Dutch greenhouse horticultural sector decreased in relative terms between 1950 and 1970 - the total European greenhouse acreage doubled - it was still, by far, the largest of its kind. Indeed, the South Holland glass district alone still contained more greenhouse hectares than England in its entirety, which includes the greenhouse concentrations in the Channel Islands. 


\subsection{Cooperative auctions}

Dutch greenhouse farmers found ways to get the highest possible price for his products through cooperative auctions. After the first cooperative auction had been established in 1889 in the Westland region, the number of cooperative auctions increased particularly in the 1900s and 1910s. ${ }^{18}$ By 1940, already $90 \%$ of the flowers, $60 \%$ of the fruits, and a full $100 \%$ of the vegetables were marketed through cooperative auctions. ${ }^{19}$ By 1917 , about 130 cooperative auctions jointly formed the Central Bureau of Dutch Horticultural Auctions, a top cooperative representing its members abroad and at the Dutch national government. While by 1900 all cooperative auctions together had a turnover of 19 million guilders, by 1940 the members of the Central Bureau of Dutch Horticultural Auctions jointly had a turnover of 1,039 million guilders, an amount quadrupling to 4,324 million guilders by $1991{ }^{20}$

Dutch agricultural cooperatives, as we have seen in chapter 5 , were usually established to give their members better access to foreign markets against fairer prices. Resistance against powerful food companies, traders, and other interfering middlemen caused many Dutch farmers to join forces and to organize the selling, distributing, and processing of their products themselves. The most important feature of the Dutch cooperative auctions was the way the actual auctioning was done. Most auctions, be it for agricultural products or, say, artefacts, work with the 'English auction' method. This method works with an ascending price, in which traders bid openly against one another. In what has become known as the 'Dutch auction' system, by contrast, the price descends from a high asking price until a trader accepts the price or until a fixed reservation price is reached, which is the minimum the selling party is asking for its product. In the Dutch cooperative auctions, in which the descending price was often displayed

\footnotetext{
${ }^{18}$ P. Plantenberg, ed., 100 jaar veilingen in de tuinbouw (Amstelveen: ACT, 1987), 12-16.

${ }^{19}$ Ronald Rommes, Voor en door boeren? De opkomst van het coöperatiewezen in de Nederlandse landbouw vóór de Tweede Wereldoorlog (Hilversum: Verloren, 2014), 16.

20 These amounts are in 1991 Dutch guilders. By 1991, the membership of the Central Bureau of Dutch Horticultural Auctions had, due to mergers, declined to 23. Membership had its peak in 1947, with 162 members. W. Kemmers and L. Gijsberts, 75 jaar Centraal Bureau van de Tuinbouwveilingen in Nederland (Vianen: Habo Dacosta, 1992), 177-183.
} 
on a (counter-clockwise-turning) clock, the descending-price system increased competition among traders while also making the bidding more efficient and swift, as the first bidder could not be outbid by a competitor, as is the case in the 'English auction' method. ${ }^{21}$

Apart from granting access to better prices and working with a more efficient and more competitive bidding system, the Dutch cooperative auctions also contributed to the success of Dutch greenhouse horticulture by functioning as normative and regulative institutions. Their members had to conform to certain rules, such as quality standards. As was the case with the sugar beet cooperatives discussed in the previous chapter, the cooperative auctions could function partly because of trust, peer pressure, and social control. The cooperative auctions granted a sense of collective entrepreneurship that gave individual greenhouse farmers and the greenhouse horticultural sector as a whole a stronger position on international markets.

Table 6.2. Exports and domestic trade of the three main Westland products, 1939-1960 (in tons)

\begin{tabular}{|c|c|c|c|c|c|c|}
\hline & $\begin{array}{l}\text { Export } \\
\text { Grapes }\end{array}$ & Lettuce & Tomatoes & $\begin{array}{r}\text { Domestic trade } \\
\text { Grapes }\end{array}$ & Lettuce & Tomatoes \\
\hline 1939 & 6,600 & 18,650 & 32,970 & 9,860 & 19,610 & 4,670 \\
\hline 1946 & 6,010 & 10,050 & 14,970 & 8,310 & 33,090 & 18,920 \\
\hline 1950 & 7,610 & 12,770 & 41,220 & 7,410 & 27,540 & 18,700 \\
\hline 1953 & 6,200 & 17,500 & 71,600 & 6,800 & 28,500 & 18,100 \\
\hline 1961 & 2,000 & 43,900 & 179,500 & 8,700 & 35,200 & 29,600 \\
\hline
\end{tabular}

Source: L. Gijsberts, 'De vraag naar Westlandse groenten en fruit', in: W.H. Kemmers, ed. Van Crisis to Kracht. Gedenkboek ter gelegenheid van het vijfenzeventig-jarig bestaan van de Bond Westland (Naaldwijk: Bond Westland, 1964), 133-154.

Apart from the sudden export growth shortly after the First World War, also the export boom in the 1950s is remarkable and was arguably the foundation for the second phase of greenhouse acreage growth during the 1950s and 1960s, as identified in Graph 6.1. In the 1950s and the 1960s the cooperative auctions again aided the greenhouse farmer in accessing international

\footnotetext{
${ }^{21}$ Plantenberg, 100 jaar veilingen in de tuinbouw, 12-16.
} 
markets. The growth in tomato exports from the Westland region since the Second World War, as depicted in Table 6.1. above, is particularly eye-catching and reveals that the Westland greenhouse farmers opened up new (international) market niches (tomatoes and, to a lesser extent, lettuce) once other niche markets had closed, as was the case with the declining export of grapes, which had once been the most important Westland product. This example gives a simple indication of the dynamics of the Dutch greenhouse revolution: through institutional innovation and cutting-edge technology Dutch greenhouse farmers aimed to walk ahead of international competitors.

\subsection{The Agricultural Guarantee Fund}

The astonishing growth of Dutch greenhouse horticulture during the twentieth century would not have been possible without a well-functioning agricultural credit infrastructure. Dutch agricultural credit infrastructure was characterized by the many cooperative rural banks, in which farmers, as shareholders, pooled their savings to create credit funds. ${ }^{22}$ Since the late 1890s the number of Dutch cooperative rural banks increased rapidly. By 1900, there were 67 cooperative rural banks, increasing to 838 cooperative rural banks by 1913 and culminating in 1,320 cooperative rural banks, with in total 434,000 members, by $1960 .{ }^{23}$ Since the late $1890 \mathrm{~s}$ these cooperative rural banks had organized themselves in two central cooperatives: the Centrale Raiffeisen Bank, located in Utrecht, which attracted cooperative rural banks from Protestant regions, and the Centrale Boerenleenbank, located in Eindhoven, which mostly had Catholic cooperative rural banks as its members. These two central cooperative banks

\footnotetext{
${ }^{22}$ Rommes, Voor en door boeren? De opkomst van het coöperatiewezen in de Nederlandse landbouw vóór de Tweede Wereldoorlog, 239-46.

${ }^{23}$ M.L. Saxena, Agricultural Credit in the Netherlands (The Hague: Institute of Social Studies, 1962), 16 and 20 21.
} 
eventually merged in 1972 to become the Rabobank, currently still one of the major Dutch banks. $^{24}$

The cooperative rural banks were particularly important for Dutch greenhouse horticulture. In the South Holland glass district specifically, by 1959 more than fifty percent of the financial liabilities of greenhouse farmers came from cooperative rural banks. ${ }^{25}$ A 1957 survey conducted by the Eindhoven central cooperative bank and the Utrecht central cooperative bank calculated that in the Westland region there were 102 loans per 100 farmers (meaning that some farmers had multiple loans). In other regions in the Netherlands these figures were much lower, namely between 33 and 76 loans per 100 arable or livestock farmers. The Eindhoven and Utrecht central cooperative banks jointly had 3,852 debtors in the Westland region, who together had received 29.8 million guilders. The average of 14,950 guilders per Westland debtor was the highest for the entire country. ${ }^{26}$ Dutch greenhouse horticulture, in sum, relied heavily on credit provided by cooperative rural banks.

Although the Dutch agricultural credit infrastructure was characterized by the many cooperative rural banks, the Dutch central government also played a crucial role, particularly in solving the issue of low creditworthiness of small farmers. During the Great Depression of the 1930s, cooperative rural banks became sometimes hesitant to entrust money to farmers who did not own sufficient private property to be used as guarantee. ${ }^{27}$ As a response, in 1930 the Eindhoven central cooperative bank set up its Guarantee Fund for Agriculture and Horticulture (Garantiefonds voor de Land- en Tuinbouw). When in need of a guarantee, farmers could apply to this fund to have a maximum of $10 \%$ of a loan guaranteed. The Utrecht central cooperative

\footnotetext{
${ }^{24}$ Keetie Sluyterman et al., Het coöperatieve alternatief. Honderd jaar Rabobank 1898-1998 (The Hague: Sdu Uitgevers, 1998), 129-38.

${ }^{25}$ R.R.W. Folley, The Role of Credit in Business Growth: An Example from the Netherlands. An Examination of Dutch Glasshouse Growers' Use of Agricultural Credit Banks and Other Credit Sources during the Expansion Period 1952-1965. (Ashford: Wye College, 1968), 10.

${ }^{26}$ Het landbouwkrediet in Nederland. Rapport van de Commissie Landbouwkrediet (The Hague: Cedo Nulli, 1960), Bijlage II, 6; Bijlage II, 8; Bijlage II, 10; Bijlage II, 11.

${ }^{27}$ Sluyterman et al., Het coöperatieve alternatief. Honderd jaar Rabobank 1898-1998, 42-44.
} 
bank had a comparable fund, as in 1946 the Mutual Guarantee Fund (Onderling Waarborgfonds), initially set up as an insurance fund for individual cooperative rural banks, was opened up for individual farmers in need of a guarantee for high-risk loans. ${ }^{28}$

Despite these private initiatives, state intervention was still required. After the Second World War limited access to credit was recognized as preventing further rationalization of Dutch farming. One of the proposed solutions was to establish state funds, following the US example, from which small farmers with a low creditworthiness could directly borrow credit when private financial institutions dared not take the risk. Although this plan was presumably deemed too costly, the Dutch government did reserve 25 million guilders from the Marshall Aid to establish the Agricultural Guarantee Fund in 1951. In addition, special provincial guarantee funds, known as the Waarborginstituten (Guarantee Institutes), were set up between 1950 and 1958 as extra financial support for horticulture. In the 1950s these Waarborginstituten jointly already guaranteed 5.5 million guilders. ${ }^{29}$

After the Agricultural Guarantee Fund was established in 1951, its first guarantees were issued in 1952. The Fund, governed by a representative from the agricultural sector and two civil servants from the Ministry of Agriculture and the Ministry of Finance, was advised by three committees, one advising on arable and livestock farming, one on horticulture, and one on trade and industry..$^{30}$ These advisory committees, also made up of representatives of the agricultural sector and of civil servants, were to judge the applications. Although the Fund was initially meant to stimulate mechanization, in practice a majority of the loans the Fund guaranteed concerned barns and greenhouses. The rule of thumb was that the loans guaranteed

\footnotetext{
${ }^{28}$ Saxena, Agricultural Credit in the Netherlands, 52-58.

${ }^{29}$ All provinces but Limburg and Friesland had its own Waarborginstituut. In 1957 the Dutch government also introduced the ' $2 \%$ credit arrangement' ( $2 \%$ krediet regeling), a special fund from which small horticultural farmers could get a loan of maximum 10,000 guilders against merely $2 \%$ interest. It is unfortunately unknown how many farmers used this fund and until when it existed. Het landbouwkrediet in Nederland. Rapport van de Commissie Landbouwkrediet, 71, 210, and 229.

${ }^{30}$ This last advisory committee was appointed to deal with applications concerning for instance cooling houses, potato storage units, and milling companies.
} 
by the Fund had to improve productivity, although in some instances the board of the Fund felt obliged to grant financial aid in times of crises, as with water or hail damage or with limited access to fuel or certain raw materials. ${ }^{31}$

Applications for guarantees from individual farmers had to be handed in to their local cooperative rural bank or to a public agricultural consultant, who passed on the application to one of the three advisory committees. When it was certain that the applicant had difficulty finding guarantees, that the applicant was considered to be of good conduct, and that the applicant was expected to keep his financial obligations, his application would be approved. The Fund only guaranteed a maximum of $50 \%$ (later $40 \%$ ) of the entire loan, as the applicant was expected to also apply to the earlier-mentioned Waarborginstituten or to find guarantees at his local cooperative rural bank or through his personal network. As the limitations to the guarantees could pose a problem especially for young farmers, exceptions were occasionally made. In some instances, the Fund went as far as to guarantee a loan for a full $100 \%$. The advisory committee for arable and livestock farming declined $25 \%$ of its applications, while the advisory committee for horticulture had to decline $40 \%{ }^{32}$

It has been estimated that the Agricultural Guarantee Fund has guaranteed 800 million guilders of investments in the first two decades of its existence. Given that the Fund only guaranteed a maximum of $40 \%$ of an entire loan, it can be calculated that the Fund has enabled a total of two billion guilders of investments. ${ }^{33}$ More than $90 \%$ of these two billion guilders was provided by cooperative rural banks, and within its first 25 years the Fund improved the creditworthiness of approximately 30,000 farmers. ${ }^{34}$ The Agricultural Guarantee Fund, in sum,

\footnotetext{
${ }^{31}$ Peter Priester, "Boeren met machines," in Techniek in Nederland in de twintigste eeuw. Deel III: Landbouw, voeding, ed. H.W. Lintsen (Zutphen: Walburg Pers, 2000), 64-71. P.J. Boutkan, "Wat deed het Borgstellingsfonds," Bedrijfsontwikkeling, 7, no. 7/8 (August 1976): 514.

${ }^{32}$ Het landbouwkrediet in Nederland. Rapport van de Commissie Landbouwkrediet, 73-74.

${ }^{33}$ W. de Wit, "Twintig jaar Borgstellingsfonds voor de Landbouw (1951-1971)," Bedrijfsontwikkeling, 3, no. 10 (October 1972): 871.

${ }^{34}$ A. de Zeeuw, "25 jaar Borgstellingsfonds voor de Landbouw," Bedrijfsontwikkeling, 7, no. 7/8 (August 1976): $507-8$.
} 
improved the Dutch agricultural credit infrastructure, enhancing the creditworthiness of a large number of small farmers, and reduced the risk for cooperative rural banks.

The Agricultural Guarantee Fund was particularly important for Dutch greenhouse horticulture: the guarantees granted to Dutch greenhouse horticulture were usually higher than the guarantees to the Dutch arable and livestock sector combined. ${ }^{35}$ The importance of the Agricultural Guarantee Fund for Dutch greenhouse horticulture is supported by qualitative evidence. The earlier-mentioned 1957 survey into Dutch agricultural credit distributed questionnaires to farmers all over the country. When asked if the Agricultural Guarantee Fund was well-known among farmers, $88 \%$ of the Westland respondents answered positively, as did $58 \%$ of the respondents from the remaining part of the South Holland glass district. In other regions, by contrast, this percentage was much lower, between merely $7 \%$ in the Veenkoloniën and $37 \%$ in the sandy regions of Noord-Brabant and Limburg. Also, when asked whether the Agricultural Guarantee Fund functioned properly, slightly more than half of the respondents in the horticultural regions answered positively $-59 \%$ in the Westland region being the highest whereas these rates did not exceed $46 \%$ in the non-horticultural parts of the country. ${ }^{36}$

The connection between the Agricultural Guarantee Fund and greenhouse horticulture can obviously be explained by the high capital intensity of greenhouse horticulture as well as its nature - with few hectares of land, many greenhouse farmers often had little private property to be used as guarantee. The overrepresentation of greenhouse horticulture in the financial support by the Agricultural Guarantee Fund tells us that after the Second World War the government was willing to solve the inconsistencies in the Dutch agricultural credit infrastructure that potentially hampered agricultural development. It is illustrative for the way public-private collaboration solved market problems in order to help the Dutch agricultural

\footnotetext{
${ }^{35}$ Verslagen van den Landbouw, 1952-1966.

${ }^{36}$ Het landbouwkrediet in Nederland. Rapport van de Commissie Landbouwkrediet. Question 18.1 and 18.2 in Bijlage III, 4 blad 5.
} 
sector achieve on international markets; it is also telling of the state agricultural policy shortly after the Second World War, which was concentrated on stimulating the capital intensification of small farming.

\subsection{The knowledge system of the South Holland glass district}

As suggested in the introduction to this chapter, greenhouse horticulture has always been much more knowledge-intensive than other non-greenhouse agriculture. It can thus be presumed that greenhouse horticulture had a heavier reliance on knowledge exchanged through 'formal' channels, such as research institutes and publicly-funded education. In his sociological study on the relationship between Dutch greenhouse horticulture and science, Vijverberg, himself a former greenhouse horticultural consultant, explains why greenhouse horticulture has a high knowledge intensity. Whereas arable farmers can only influence the growth of their crops by carefully treating the soil, by adding water when necessary, and during the sowing phase of the season, greenhouse farmers have more options to intervene in the production process of their crops. Greenhouse farmers have a certain degree of control over temperature, light, and air quality, a control that their non-greenhouse counterparts lack. When the temperature, light, air quality, or any other variable in a greenhouse is less than optimal, the quality of the product, and consequently its market value, swiftly decreases. ${ }^{37}$

It is not surprising, then, that the South Holland glass district, with its high density of greenhouse farmers, cooperative auctions, research institutes, horticultural schools, and supply companies (greenhouse construction builders, seed companies, etc.), has since long been an international centre for horticultural research and education. The early origins of this knowledge network can be traced back to the first government involvement in this sector. As we saw in chapter three, the Agricultural Committee of 1886, investigating how the Dutch government

\footnotetext{
${ }^{37}$ Vijverberg, Glastuinbouw in ontwikkeling. Beschouwingen over de sector en de bënvloeding ervan door de wetenschap, 52-54.
} 
could solve the Agricultural Depression, came to the conclusion that publicly-funded education was required, also for horticulture. Following this advice, the government erected the first State Horticultural Winter School (Rijkstuinbouwwinterschool) in Naaldwijk in the Westland region in 1896, after which more followed elsewhere. Apart from horticultural education, the government also funded horticultural consultancy, as it employed 9 horticultural consultants, one of which was stationed in Naaldwijk. Local agricultural societies, meanwhile, joined forces to establish an 'Experimental Garden' (Proeftuin) in Naaldwijk in 1898, which was later transformed into an experiment station. In the following decades this experiment station worked together with the local horticultural consultant to study, among other things, fertilizers, plant breeding, and greenhouse temperature management. ${ }^{38}$

In the early years, there was not enough know-how within the South Holland glass district to meet the demand for knowledge and innovation. Van Rooij et al study a relatively large greenhouse farmer from the Westland region in the first decade of the twentieth century who travelled abroad and asked his traders to gain the information necessary to successfully expand his business. With this case study in hand, Van Rooij et al nuance the idea, prevalent among innovation scholars, that knowledge systems originate and develop primarily on the level of the nation state. The South Holland glass district, by contrast, was a regional knowledge network that gained from the international contacts of some of its components. ${ }^{39}$ First copying foreign innovations and importing knowledge, the knowledge system matured and gradually started producing its own novel technology later on.

Important components of this knowledge system were the study clubs (tuinbouw studieclubs) in which greenhouse farmers participated. Starting in the 1920s, by the 1950 s there

\footnotetext{
38 J. Barendse, 25 Jaar Tuinbouwonderwijs, -Voorlichting, -Onderzoek in Het Zuid-Hollands Glasdistrict 19241949, 1949.

${ }^{39}$ Arjan van Rooij et al., "National Innovation Systems and International Knowledge Flows: An Exploratory Investigation with the Case of the Netherlands," Technology Analysis \& Strategic Management, 20, no. 2 (2008): $153-56$.
} 
were 17 study clubs with 3,000 members in the Westland area alone. Within these clubs, greenhouse farmers not only discussed technological improvements and shared experiences, but also communicated directly with the experiment station in Naaldwijk, the local horticultural consultant, and later also with researchers from the agricultural college in Wageningen, as the study clubs provided valuable feedback. ${ }^{40}$ Berkers and Geels, who study the knowledge system of the South Holland glass district between 1930 and 1980 with special attention for innovation in tomato production and greenhouse construction, stress that this strong public-private collaboration was needed because greenhouse farmers lacked the resources to conduct their own R\&D. Many innovations in the South Holland glass district, Berkers and Geels argue, were 'first developed by universities, research institutes and technology suppliers, and subsequently adopted in the greenhouse system' ${ }^{41}$ For example, the private company Philips, in collaboration with scientists from the agricultural college in Wageningen and the experiment station in Naaldwijk, investigated the usage of artificial light for crop growth in greenhouses as early as the late 1920 s, even though fluorescent tubes were only implemented by the mid-1950s. ${ }^{42}$

Berkers and Geels also pose that most innovations were add-ons or replacements which cumulatively altered greenhouse horticulture but standing alone were not too risky for greenhouse farmers to adopt. Within this knowledge system, the public-private collaboration facilitated a top-down flow of knowledge, though without disregarding the needs of the individual greenhouse farmer. ${ }^{43}$ The success of this public-private collaboration is illustrated by the fact that since the 1960 s the national association of horticultural study clubs got a say in the direction of horticultural research at public research institutes. The intensity of this public-

\footnotetext{
${ }^{40}$ Van Doesburg et al., Honderd jaar praktijkonderzoek voor de glastuinbouw. Meten $=$ weten.

${ }^{41}$ Eric Berkers and Frank W. Geels, "System Innovation through Stepwise Reconfiguration: The Case of Technological Transitions in Dutch Greenhouse Horticulture (1930-1980)," Technology Analysis \& Strategic Management, 23, no. 3 (2011): 224.

${ }^{42}$ For the greenhouse horticultural research of Philips, see K. Boersma, "Creating an Agricultural Research Network: Irradiation of Plants with Artificial Light at Philips Research in the 1930s," Business and Economic History On-Line, 2 (2004): 1-27.

${ }^{43}$ Berkers and Geels, "System Innovation through Stepwise Reconfiguration: The Case of Technological Transitions in Dutch Greenhouse Horticulture (1930-1980),” 224.
} 
private collaboration, Dutch scholars of innovation have noted, was not easily found in other Dutch agricultural subsectors and explains the innovative character of Dutch greenhouse horticulture in general and the South Holland glass district in particular. ${ }^{44}$

\subsection{Conclusion}

This chapter has aimed to explain what has been referred to as the Dutch greenhouse revolution. Only a small sector compared to counterparts in England, Belgium, and the United States in 1900, in the following decades the Dutch greenhouse sector grew to become, by far, the largest of its kind. This growth occurred particularly during the late 1910s and the 1920s and during the 1950 s and the 1960s, two periods during which, as we have seen in chapter two, international trade flourished and Dutch greenhouse farmers fully profited from increasing demand for fruits, vegetables, and flowers. Meeting this demand was successfully done largely by restructuring the institutional landscape, which occurred in three ways.

Firstly, since the early 1900s cooperative auctions gave better access to international markets against better prices. Secondly, since the early 1900s cooperative rural banks jointly constituted the Dutch agricultural credit infrastructure, into which the Dutch government intervened with the Agricultural Guarantee Fund during the 1950s and the 1960s to improve the creditworthiness of small horticultural farmers particularly, hence stimulating the international competitiveness of the Dutch greenhouse horticulture. Thirdly, since the 1890 s the South Holland glass district developed into a knowledge network, at first depending heavily on foreign innovation but later becoming a world leader in its own right, largely by a successful and rather unique collaboration between public institutes and private parties, most notably the

\footnotetext{
44 J.W. Grooters, "Tuinbouw onder glas en varkenshouderij. Vergelijking tussen twee landbouwkennissystemen in Nederland," Landbouwkundig Tijdschrift 103, no. 5 (1991): 27-29. Vijverberg, Glastuinbouw in ontwikkeling. Beschouwingen over de sector en de beïnloeding ervan door de wetenschap, 18 and 142.
} 
horticultural study clubs. These three institutional changes, this chapter has argued, have driven the Dutch greenhouse revolution.

When overseeing the economic development of Dutch greenhouse horticulture between c. 1880 and 1970, it is not farfetched to see Dutch greenhouse horticulture as the pinnacle of the entire Dutch agricultural sector; the forces driving the Dutch greenhouse revolution can also be observed in other subsectors of Dutch agriculture. As discussed in the foregoing chapters, the development of Dutch agriculture since the late nineteenth century was very much determined by the Netherlands' proximity to expanding urban-industrial agglomerations, the high rate of self-organization of Dutch farmers, and government interference, while the combination of these three factors lead to a high level of innovativeness. For Dutch greenhouse horticulture, however, these developments seem to have been even larger, at a higher rate, and with a higher impact, leading to the Dutch greenhouse horticultural sector as we know it today. 


\section{CHAPTER VII}

\section{CONCLUSION}

\subsection{Introduction}

Currently, the Netherlands is a global leader in agricultural innovation, although this dominance was far from evident at the end of the nineteenth century. Nevertheless, the historical roots of the Netherlands' important position have scarcely been traced. This study has analysed the development of innovation in Dutch agriculture between 1880 and 1970. It aims to look for the main explanations of the successful innovative climate that had emerged during this period and finds that agricultural innovation is not determined merely by changing land-labour ratios and the need to lift ecological constraints but also by proximity to markets, an insight inspired by the field of New Economic Geography, which emphasizes, simply put, that economic activity is heavily determined by distance to customers. In close proximity to markets for their products as well as their inputs, Dutch farmers heavily specialized in niche markets. To defend their position in these small markets, or to find new niches, they had to operate at the technological frontier, which required a steady knowledge exchange. This exchange was made possible by an expanding network of agricultural cooperatives and public institutes.

Part I of this study has placed Dutch agricultural innovation in its international economic context (chapter 2) and in its political context (chapter 3), while the three chapters comprising part II have focused on specific innovations or on particular subsectors of Dutch agriculture, namely artificial fertilizers and state-led agricultural consultancy (chapter 4), plant breeding and marketing cooperatives (chapter 5), and Dutch greenhouse horticulture (chapter 6). This concluding chapter highlights the overarching arguments emerging from these preceding five chapters, detects the main limitations of this study, and delineates how this study's findings could potentially lead to further research. 


\subsection{Main Argumentation}

Contemporaries in the 1870s would never have foreseen the success of Dutch agricultural innovation in later decades. By the 1870 s, Dutch state investments in agricultural education and $\mathrm{R} \& \mathrm{D}$ were small relative to state investments in agriculture elsewhere in Europe. As private investments were also rare, the Dutch agricultural sector was heavily dependent on foreign countries for its knowledge, innovation, and technology. Yet, this picture had changed radically a century later. By the 1960s, the Dutch agricultural sector stood out for its many publicly funded research institutes, its well-functioning and expansive consultancy system, and its relatively high density of agricultural cooperatives. The Dutch agricultural sector had become highly export-oriented, not only in terms of agricultural products but also of knowledge and innovation. But why and how had Dutch farmers been able to become among the most innovative of Europe?

First of all, it is important to note that preconditions for agricultural innovation were favourable in the Netherlands. Its well-situated geographical position within Western Europe made the Netherlands a major transit centre for European trade. Because of a relatively advanced infrastructure inherited from the ancien régime, which provided good connections to London and the urban centres of Holland and Flanders, parts of the Netherlands had reached relatively high levels of agricultural specialization as early as the seventeenth century. Improvements in transportation since the mid-nineteenth century also integrated the more remote parts of the country into international markets.

The location of the Netherlands was a crucial condition to benefit from the international economic context. Due to the repeal of the British Corn Laws in 1846, Dutch agricultural products could be dumped on the nearly insatiable British food market against high prices. However, trade liberalization also had its drawbacks. Prices plummeted once arable products from distant regions, such as Eastern Europe and the Americas, invaded the Western European 
food markets, resulting in the Agrarian Depression of the 1870s and the 1880s. As argued in chapter 2, the Agrarian Depression stimulated Dutch farmers to continue specializing. Industrialization, urbanization, and rising living standards in surrounding countries increased the demand for higher-value products. Their proximity to urban-industrial agglomerations in Britain and Germany provided Dutch farmers the opportunity to specialize in higher-value products, to profit from integrating markets, and to position themselves in specific niche markets, as illustrated, for instance, by the straw board industry, the potato starch industry (both discussed in chapter 5), and Dutch greenhouse horticulture (chapter 6).

However, the favourable location within Western Europe and the international economic context are not sufficient to fully explain the success of Dutch agricultural innovation nor do they imply that this success was inevitable. Other European countries, such as Belgium, Ireland, and the Scandinavian countries, were also closely located to urban-industrial agglomerations in Germany and Britain, yet followed very different development patterns. This study argues, therefore, that the success of Dutch agricultural innovation should also be attributed to institutional factors. First, there was the stimulating, facilitating, and steering role of the Dutch government, and, secondly, a relatively high degree of self-organization of the Dutch farming population.

Although Dutch agriculture had since long been relatively export-oriented, chapter 2 has revealed on the basis of trade statistics that the 1880s and the 1890s, at the end of the Agrarian Depression, showed a particularly fast increase and diversification in Dutch agricultural export. Between 1880 and 1915 the export of processed products, both livestock and arable products, increased four-fold, while vegetable exports increased fivefold. The shift from grain production to higher-value arable products, such as potatoes, sugar beets, fruits, and vegetables, resulted in more intensive cultivation systems and in a higher usage of artificial fertilizers. As explained in chapter 2, 'locally-produced innovation', which included 'on-farm' 
inputs and knowledge being exchanged through tradition, informal networks, and village communities, was supplemented (or substituted) by 'externally-produced innovation', with 'off-farm' inputs provided by external suppliers. The traditional networks no longer sufficed, which implied that knowledge had to be exchanged through more 'formal' networks, such as education, media, consultancy, and cooperatives.

Chapter 3 has argued that the weak bargaining position of Dutch farmers with regard to their input suppliers and the inadequacy of the existing networks to provide farmers with knowledge were the main reasons for the Dutch government to abandon its passive agricultural policy. Although first steps for public agricultural education and R\&D had been taken in the 1870 s, government involvement increased particularly during the 1890 s and 1900 s, which is best illustrated by the expanding agricultural consultancy system and the growing number of agricultural experiment stations and research institutes. In this same period, the Netherlands saw a rapid increase in agricultural cooperatives. Although these existed throughout Europe in all forms and sizes, the Dutch case stands out for the wide range of cooperatives. Nearly all subsectors of Dutch agriculture, be it the dairy sector, the potato starch industry, the sugar industry, the straw board industry, or the fruit and vegetable industry, were dominated by cooperatives, which functioned as buyers of products, processors of products, and suppliers of inputs. Chapter 4 shortly highlighted the importance of supply cooperatives for the distribution of artificial fertilizers, while chapter 5 went into detail on the various ways marketing cooperatives improved the innovation capacity of their farming members. Chapter 6 stressed the role of cooperative auctions in marketing vegetables, fruits, and flowers and explained how credit provided by cooperative rural banks was pivotal for the growth of Dutch greenhouse horticulture.

From the 1880s until the First World War, the expanding public-private networks of agricultural cooperatives and government institutes mainly diffused innovation and knowledge 
imported from abroad. With its connections to foreign industrialized centres and its proximity to trade hubs, most notably the port of Rotterdam, the Dutch agricultural sector profited from 'geography of innovation'. Chapter 2 has presented evidence that Dutch farmers gained from innovative activity in surrounding countries: both artificial fertilizers and high-quality seeds were largely imported from Germany. However, the First World War disrupted the imports of inputs, while the ongoing specialization of Dutch agriculture in the following decades, which brought Dutch farmers at the technology frontier, was another stimulus to reduce dependency on foreign knowledge and innovation. Since the 1920s, though sooner or later for some subsectors, the Dutch agricultural sector generated its own knowledge and innovation. This shift from imported innovation to 'home-grown' innovation is telling for the resilience of the Dutch agricultural sector as well as its capacity to respond to changes and its ability to selforganize. Chapter 5 has shown how the Dutch sugar beet cooperatives set up their own knowledge networks, invested in a Dutch seed company, and established their own research institute.

During the Interbellum, then, the Dutch cooperative movement was at its peak (in terms of numbers of cooperatives) and public-private collaboration, which occurred on the local and the national level, intensified. In the South Holland glass district, for instance, greenhouse farmers joined local study clubs that collaborated with the horticultural experiment station in Naaldwijk and that were in direct contact with researchers at the agricultural college in Wageningen. Agricultural consultants used local farmer organizations as vehicles to reach the individual farmer. On the national level, the collaboration between agricultural cooperatives, sometimes leading to the establishment of overarching top cooperatives, increased the bargaining power of the Dutch agricultural sector as a whole.

The well-established networks of agricultural cooperatives and public institutes also contributed to the success of Dutch agricultural innovation by integrating smaller farmers, often 
from Dutch regions that had previously lagged behind, into their networks. Chapter 5, for instance, showed how sugar beet cultivation diffused from the south-western corner of the Netherlands to other regions during the 1940s and 1950s, while chapter 6 has shown how greenhouse farmers all over the Netherlands profited from innovative activities in the South Holland glass district. This converging effect of agricultural innovation was strengthened by the governmental policy to improve the competitiveness of small farmers. Since the Great Depression of the 1930s, Dutch agricultural consultancy was especially directed towards stimulating small farmers to specialize and to intensify fertilizing. After this only proved partly successful, many small farmers left the agricultural sector, which made way for the scaling-up and mechanization of Dutch agriculture after the 1960s.

To sum up, the necessary condition for the success of Dutch agricultural innovation was the combination of high degree of self-organization of the Dutch farming population and strong state involvement. This mixture put the Netherlands in an optimal position to gain from the proximity to the growing numbers of urban consumers all over Western Europe. Since the 1880s the need to specialize in niche markets pushed Dutch farmers to the technological frontier. This mechanism proved to have a 'snowball effect': niche markets urged Dutch farmers to innovate, and once innovation capacity was improved through knowledge networks established by agricultural cooperatives and public institutes, new niche markets could be found.

\subsection{Theoretical Contributions}

How do the findings in this study relate to theories on agricultural innovation? As discussed in the introductory chapter, one dominant approach to agricultural innovation is what I have labelled the 'factor endowments approach', which is represented most clearly in the work of Yujiro Hayami and Vernon W. Ruttan. They argue that innovation is induced by economizing 
either on land or labour: when land prices increase relative to labour prices, this prompts landsaving innovation, whereas when labour prices increase relative to land prices, this leads to labour-saving innovations. ${ }^{1}$ An important counterargument has been presented by Alan L. Olmstead and Paul W. Rhode. Their 'ecological approach' emphasizes that, besides saving on the relatively scarce production factor, farmers also go to great lengths to increase control over their direct environment and to lift ecological constraints, such as weeds, diseases, insects or detrimental changes in water availability, soil fertility, climate, and seasonal character. ${ }^{2}$

Both approaches, largely based on North American agricultural history, pay limited attention to access to (foreign) markets as an explanatory factor for the development of agricultural innovation. The Dutch case, this study argues, points to the importance of the New Economic Geography and a Von Thünen perspective when studying agricultural innovation in the past. In its most simple terms, the Von Thünen model prescribes that, the closer a farmer is located to the urban market, the more diversified, specialized, and intensified his farming is. Closely located to British and German urban-industrial agglomerations, Dutch farmers operated nearby the Von Thünen centre of the agricultural markets they were part of. As a result, their farming was often more diversified, specialized, and intensified than the farming of their international competitors. International competition urged Dutch farmers to shift from grain production to the cultivation of higher-value cash crops, which required a different cultivation system, a more laborious soil treatment, and a more intensive usage of fertilizers. The ongoing need to find market niches and to compete with international counterparts, who often had a comparative advantage (with better climatic conditions or lower production costs), brought Dutch farmers to the technological frontier.

\footnotetext{
${ }^{1}$ Yujiro Hayami and Vernon W. Ruttan, Agricultural Development. An International Perspective, 2nd ed. (Baltimore: The Johns Hopkins University Press, 1991), 4-5.

${ }^{2}$ Alan L. Olmstead and Paul W. Rhode, Creating Abundance. Biological Innovation and American Agricultural Development (Cambridge: Cambridge University Press, 2008), 386-402.
} 
Dutch greenhouse horticulture is the most vivid example of a subsector in which technological advancement was directly determined by the access (and proximity) to international markets. In the early 1900s, the need to grow grapes for urban consumers had introduced the usage of greenhouses. Once this market was lost to Mediterranean competitors during the 1920s, the new niche of tomatoes propelled Dutch greenhouse farmers to start heating their greenhouses, which was only possible with coal imported through nearby Rotterdam. Their location, close to the port of Rotterdam with excellent connections to Britain and Germany, as well as their capacity to organize themselves in cooperatives and study clubs made Dutch greenhouse horticultural farmers the pinnacle of Dutch agricultural innovation. This specific case illustrates how market access can explain variations in agricultural innovation in the past.

Dutch farmers, then, were successful in niche markets largely because they had access to knowledge. Historians have not reached consensus on the role of knowledge in the development of agriculture in the twentieth century. Some highlight that without knowledge, particularly 'useful knowledge' as defined by Joel Mokyr, European agriculture could never have developed in the way it did, possibly with detrimental effects for food security, economic development, and general welfare. Others, however, argue that the knowledge-intensive growth of agriculture was enforced upon the European farming population at great costs. Juri Auderset and Peter Moser argue that an 'industrial paradigm' was imposed on farmers, which changed Europe into an 'agrarian-industrial knowledge society' in which traditional ways of farming ultimately disappeared. ${ }^{3}$ Frank Uekötter adds that when agriculture is 'industrialized', the tacit

\footnotetext{
${ }^{3}$ Juri Auderset and Peter Moser, Die Agrarfrage in der Industriegesellschaft. Wissenskulturen, Machtverhältnisse und natürliche Ressourcen in der agrarisch-industriellen Wissensgesellschaft (1850-1950) (Cologne: Böhlau Verlag, 2018), 11 and 20.
} 
knowledge of the individual farmer, once taking into account the complexities and local characteristics of farming, is forever lost. ${ }^{4}$

Whereas Auderset, Moser, and Uekötter base their views on German and Swiss agricultural history particularly, evidence from the Dutch case shows, firstly, that the 'industrial paradigm' was often supported by the Dutch farming population, and, secondly, that the ‘industrialization' of farming was not necessarily detrimental to location-specific knowledge. The tightening grip of the Dutch government on Dutch agriculture provided opportunities for the top-down encouragement of a what contemporaries called 'modern' farming, particularly after the Agrarian Depression of the 1930s, which had made painfully clear that the many Dutch small farmers were unable to keep pace with competitors. Dutch agricultural consultants, chapter 4 has explained, advocated the 'rationalization' of small farming, stimulating the usage of more artificial fertilizers, better machinery, and other seeds. The ideal of a more 'rational' farming was also passed on through local agricultural education, through local agricultural organizations, and through cooperatives. It is difficult to assess, however, to what extent this ideal was actually imposed. The archival records of the agricultural consultant Elema, explored in chapter 4, contain evidence of farmers eagerly following the advice to use artificial fertilizers more intensively. Evidence from Dutch marketing cooperatives, studied in the fifth chapter, suggests that their members supported technological advancement and knowledge-intensive growth; members of the sugar beet cooperatives, for instance, were aware that their industry could withstand international competition only by 'industrializing'.

The introductory chapter of this study has followed Olmstead and Rhode's argumentation that the location-specific nature of farming implies, firstly, that farmers innovate continuously to solve problems caused by older innovations (illustrated by the concept of the 'Red Queen's dictum'), and, secondly, that farmers are at the centre of innovation adoption,

\footnotetext{
${ }^{4}$ Frank Uekötter, Die Wahrheit ist auf dem Feld. Eine Wissensgeschichte der deutschen Landwirtschaft, 3rd ed., Umwelt und Gesellschaft 1 (Göttingen: Vandenhoeck \& Ruprecht, 2012), 43, 270, and 435-36.
} 
since they adapt innovations to location-specific circumstances. ${ }^{5}$ Evidence of the locationspecific nature of agricultural innovation was found throughout this study. The Dutch agricultural consultancy system, for example, was organized in geographical districts, which decreased in size over time, in order for consultants and their assistants to better take into account soil conditions, water availability, and other location-specific variables. The sugar beet cooperatives set up their own R\&D and organized experimental fields to determine why certain crop varieties did or did not function on certain soil types. The horticultural study groups in the South Holland glass district, as a last example, searched for the greenhouse construction most suitable for their local conditions and provided researchers with feedback on how certain technologies functioned locally.

Auderset, Moser, and Uekötter have argued that the 'industrialization' of European agriculture disregarded location-specific knowledge and circumstances. The knowledgeintensive growth of Dutch agriculture, however, seems to have increased the knowledge of Dutch farmers on local variables, such as soil conditions. Rather than only imposing simplistic and generalizing principles top down, the expansion of knowledge networks since the late nineteenth century stimulated Dutch farmers to better adapt innovations to local circumstances.

\subsection{Limitations and Future Research}

The research in this study has its limitations, in particular due to its source material and its analytical approach. First of all, this study is based mainly on archival material from government institutes and agricultural cooperatives and on agricultural periodicals (particularly in chapter 3). Because most archival sources come from organizations that constituted formal knowledge networks, the significance of informal knowledge networks, i.e. family ties, village

\footnotetext{
5 Alan L. Olmstead and Paul W. Rhode, "Conceptual Issues for the Comparative Study of Agricultural Development," in Agriculture and Economic Development in Europe Since 1870, ed. Pedro Lains and Vicente Pinilla (London: Routledge, 2009), 43.
} 
communities, etc., all typically without archival material, might be underestimated. As of yet it is unclear how informal and formal knowledge networks interacted, to what extent they overlapped, and if the formal knowledge networks replaced the informal knowledge networks or merely supplemented them. Also, the conclusions drawn from these sources might apply to larger Dutch farmers but less to smaller ones. Although by 1940 an estimated $90 \%$ of Dutch farmers was a member of a cooperative, in earlier decades only the larger farmers could afford being a shareholder of a cooperative. When studying archival records of sugar beet cooperatives from the early 1900s, this provides insight particularly in how larger Dutch farmers operated and communicated, but might tell us less about smaller farmers.

Secondly, because the approach of this study consisted for a large part of actor-based case studies, which provides opportunities for in-depth investigation, other components of the larger picture are excluded. Focussing on Dutch arable farming, this study has given less attention to developments in those regions where livestock production dominated, such as the provinces of Friesland and Holland. Also other specific agricultural regions, such as the river clay areas in the centre of the country, have not been extensively studied.

A last issue is the sometimes unclear causality. The innovativeness of Dutch farmers, this study has found, can for a significant part be attributed to the high density of agricultural cooperatives. However, was the high density of cooperatives an explanatory variable for the success of Dutch agricultural innovation or was it an effect of the success of Dutch agricultural innovation? The presence of agricultural cooperatives in the Netherlands has been presented as a given; explaining why the Netherlands had such a high density of cooperatives was outside this study's scope. Yet, when going one step further in understanding the history of Dutch agriculture, one has to explain why since the 1880 s the Netherlands saw such a rapid and expansive growth in agricultural cooperatives. Where did all this social capital come from? Was the Dutch cooperative movement stimulated by the rural elite, as Paul Sharp and Markus Lampe 
have shown for the Danish dairy industry, or did it originate in the poldermodel, which allegedly followed from the presumed familiarity of the Dutch population with negotiating and collaborating due to its shared battle against water? ${ }^{6}$

Questions in a similar vein could be raised about the Dutch agro-food industry, which, not rarely farmer-owned through cooperatives, gave Dutch farmers better access to inputs and provided extra knowledge networks, thereby increasing the innovativeness of Dutch farmers. How can the swift rise of the Dutch agro-food industry since the mid-nineteenth century be explained? Is it a consequence of the lack of heavy industry, which lead Dutch urban elite to invest in food companies instead, or might other forces be at play? In sum, this dissertation shows that a deeper understanding of specific aspects of the development of Dutch society and the Dutch economy is still required.

Knowledge, Networks, and Niches, the title of this dissertation, refers to the attributes of the Dutch agricultural sector that explain the current success of Dutch agricultural innovation. Due to international competition, the Netherlands' location in Western Europe, and the growing demand for higher-value goods throughout Europe, Dutch agriculture experienced a continuing specialization in niche markets since the 1880s. This high level of specialization brought Dutch agriculture at the technological frontier, a situation maintained by to the ability of the Dutch agricultural sector, in close collaboration with the government, to set up suitable networks. Agricultural cooperatives, publicly funded research institutes, and public agricultural consultants diffused knowledge among the Dutch farming population, helped adapt foreign knowledge and technology to the specific Dutch conditions, and generated new knowledge and technology that could not be imported from abroad. Moreover, also smaller Dutch farmers, once

\footnotetext{
${ }^{6}$ Markus Lampe and Paul Sharp, A Land of Milk and Butter. How Elites Created the Modern Danish Dairy Industry (Chicago: University of Chicago Press, 2018). Jan Luiten van Zanden and Maarten Prak, Nederland en het poldermodel. De economische en sociale geschiedenis van Nederland, 1000-2000 (Amsterdam: Bert Bakker, 2013).
} 
unable to follow their larger counterparts, were integrated into these networks, resulting in convergence. With these findings, this dissertation has two main contributions. Firstly, this dissertation has presented evidence that proximity to markets has been a driving force behind agricultural innovation in the past, besides changing land-labour ratios and ecological constraints. Secondly, the case of Dutch agricultural innovation points out that the knowledgeintensive growth of agriculture did not exclusively follow from expert knowledge trickling down or being enforced upon the general farming population. Rather, many Dutch farmers recognized that their farming had to intensify in order to withstand international competition and to safeguard their livelihoods - to survive, knowledge was needed. 


\section{SUMMARY}

The September 2017 issue of the National Geographic magazine contained an article wondering why the Netherlands, this small, urbanized, and densely-populated country in Western Europe, is the second world exporter of food. The answer is found in the innovativeness of Dutch agriculture. With drones, GPS, and artificial intelligence, Dutch arable farmers detect the progress of individual crops and measure, per square meter rather than per plot, the required inputs. But why is Dutch agricultural innovation world leading?

This study explains the success of Dutch agricultural innovation by looking at its historical roots. Why and how, this dissertation asks, were Dutch farmers able to become among the most innovative in Europe? This dissertation points out, firstly, that preconditions in the Netherlands were favourable. With their close location to the port of Rotterdam (the main transportation hub of Europe) and urban-industrial agglomerations in Britain and Germany, Dutch farmers could fully profit from the growing demand for higher-value agricultural products. In combination with growing international competition, this lead to ongoing specialization and diversification, which brought Dutch farmers at the technological frontier.

Secondly, since the late nineteenth century the Dutch government facilitated the Dutch farming population in operating at the technological frontier by stimulating agricultural $R \& D$,

more than elsewhere in Europe, where protectionism was often the norm. Publicly funded research institutes and public agricultural consultancy were all vehicles through which knowledge and innovation was exchanged. Thirdly, the high level of self-organization of the Dutch agricultural sector compared to its international counterparts, most clearly visible in the high density and variety of Dutch agricultural cooperatives, resulted in a horizontal exchange of knowledge between farmers themselves. The public institutions and farmer organizations jointly enabled the Dutch agricultural sector, increasingly active in market niches, to adapt 
foreign innovation to the specific Dutch conditions and, once the high level of specialization had made importing innovation insufficient, to generate innovation and knowledge itself. In short, the public-private networks provided the knowledge exchange necessary to successfully farm at the technological frontier, which Dutch farmers are still doing today.

With these findings, this dissertation makes two important contributions. Firstly, whereas many scholars see agricultural innovation as a product of changing land-labour ratios or as a product of the need to lift ecological constraints, this dissertation has shown that also proximity to markets is an important determinant for the course of agricultural innovation. For Dutch farmers, the need to innovate was very much driven by the fact that they were closely located to the centre of the Von Thünen model (which prescribes that the closer a farmer is located to an urban market, the more specialized, intensified, and diversified his farming becomes) and that they had to secure their position on German and British urban markets.

Secondly, a number of agricultural historians claim that the knowledge-intensive growth of agriculture in large parts of the world during the twentieth century was driven by an 'industrial paradigm', which prescribed that agriculture should follow the methods, goals, and productivity growth of the industrial sector. This paradigm, allegedly spread among farmers by agricultural experts, disregarded the tacit knowledge of the individual farmer on, for instance, local conditions. However, evidence from the Dutch case suggests that the knowledge-intensive growth of Dutch agriculture, though certainly driven by a kind of 'industrial paradigm', was supported by the Dutch farming population, as an intensification of agriculture was one of the ways to cope with international competition. The access to knowledge improved, which made Dutch farmers more resilient to deal with competition and crises and to safeguard their livelihood. 
The main part of the inquiry is conducted through case studies, focusing on specific innovations or particular subsectors within Dutch agriculture. These case studies are put into larger perspective by an analysis on the national level. This enables a comparative approach, which works two ways. Firstly, findings from the Dutch case are compared with the historical examples of Belgium, Denmark, Germany, Britain, and in some cases the United States. Secondly, this study compares regions within the Netherlands, to clarify how and to what extent agricultural innovation differs locally. Because of this diversity of approaches this study uses a wide range of data and sources. The quantitative data consist of Dutch national trade statistics and Dutch agricultural statistics, while qualitative material comes from agricultural periodicals and archival records, such as minutes, annual reports, and correspondence from agricultural cooperatives, research institutes, and other actors.

Chapter 1 is the introductory chapter that presents the relevant literature, discusses the methodology and approach, and demarcates the main concepts. Important to note is that agricultural innovation differs from general innovation in two ways. Firstly, agricultural innovations do not have a high degree of portability and have to be fine-tuned to specific local conditions. Secondly, because agricultural innovations are usually human interventions in biological processes, they often cause new problems that have to be solved. Farmers are the actors having to adapt agricultural innovations to local conditions and having to detect new problems, which brings them at the heart of the innovation adoption process. Yet, because farmers have little options to organize their own research and development (R\&D), they are heavily dependent on suppliers, extension services, and research institutes (agricultural innovation, in other words, is heavily 'supplier-dominated'). Agricultural innovation, this chapter points out, is largely determined by the success of knowledge exchange between farmers and other actors. 
After the introductory chapter, part I of this dissertation places Dutch agricultural innovation in its wider context. Chapter 2 studies the international economic context and uses insights from New Economic Geography to show that Dutch agriculture profited greatly from its proximity to expanding markets in Western Europe. Dutch farmers were close to urban consumers, mainly in Germany and Britain, but also had good connections to foreign suppliers of various inputs and innovations. Trade statistics reveal that the imports of seeds and artificial fertilizers increased massively since the late nineteenth century. However, ongoing specialization and diversification brought Dutch farmers at the technological frontier, which made that importing knowledge and innovation from abroad was no longer sufficient. The Netherlands started generating its own innovation and gradually transformed into an exporter of knowledge.

Chapter 3 puts focus on the national political context. How can it be explained that the Dutch state, having ignored the agricultural cause during most parts of the nineteenth century, heavily invested in agricultural education and $R \& D$ during the twentieth century? Using agricultural periodicals, parliamentary minutes, and government documents as primary sources, this chapter finds the answer in the changing nature of agricultural innovation. For centuries, Dutch farmers had used innovations and inputs that were locally available. Since the midnineteenth century, however, Dutch farmers started relying heavily on imported fertilizers, seeds, and animal feed. Because of their lack of knowledge on these imported inputs, many individual farmers had a weak bargaining position with regard to their suppliers. Subsequent market failures caused the Dutch government to step in and improve access to knowledge, funding agricultural education and setting up agricultural experiment stations and an agricultural consultancy system. 'Protectionism of knowledge' was seen as a good alternative to the shunned 'protectionism of prices'. 
Whereas part I of this study discusses the economic and political context, part II concentrates on case studies. Chapter 4 explains why the Netherlands transformed from a relatively small user of artificial fertilizers at the end of the nineteenth century to one of the largest users of artificial fertilizers a few decades later. Besides land-labour ratios and the high level of specialization of Dutch farmers, the enormous growth in artificial fertilizer usage in the first decades of the twentieth century should also be attributed to the improved exchange of knowledge. Although other knowledge channels were also important, this chapter finds that the Dutch public agricultural consultancy system was pivotal. An international comparison shows that the Dutch agricultural consultancy system was one of the most elaborate of its time. The growing number of Dutch agricultural consultants improved knowledge exchange at the local level. The case of Jakob Elema, agricultural consultant for the province of Drenthe from the 1890s to the 1930s, exemplifies how individual consultants improve local networks and professionalized the 'on the ground' knowledge exchange. They often had a long-lasting effect on local agriculture through the education and press they helped set up.

Chapter 5 discusses the role of agricultural cooperatives. The case of the sugar beet cooperatives shows how agricultural cooperatives had a comparative advantage as knowledge networks with regard to networks provided by, for instance, agricultural consultants. Within cooperatives, individual farmers were part of a larger peer group, in which they were pressured to follow the production methods and participate in the knowledge exchange of the larger group. The archival records of the sugar beet cooperatives reveal how these groups continuously balanced between the freedom of the individual members and the uniformity and quality of the products the cooperative delivered. The sugar beet cooperatives contributed to the innovation capacity of their members by distributing knowledge and by giving access to inputs, particularly seeds. Since the late 1920 s the sugar beet cooperatives jointly conducted R\&D, eventually setting up their own research institute. 
Chapter 6 explains why the usage of greenhouses for the production of flowers, vegetables, and fruits increased massively since the 1910s, a development referred to as the 'Dutch Greenhouse Revolution'. A network of cooperative auctions and the proximity of the South Holland glass district, where most of the Dutch greenhouses were located, to the port of Rotterdam resulted in a quick shipment of Dutch horticultural products to the German and British urban consumers, which was extremely important for these perishable goods. The concentration of Dutch greenhouse acreage in South Holland resulted in a high density of experiment fields, study clubs, suppliers, and researchers, which improved knowledge exchange. Together with the willingness of cooperative rural banks and state guarantee funds to invest in greenhouse horticulture, this explains why the Dutch greenhouse horticultural sector became the largest of its kind and became a world leader in greenhouse horticultural technology.

Chapter 7 concludes by summarizing the main findings of this dissertation and reiterating the main line of argumentation. It shortly recaps the main contributions of this dissertation and reflects on its main two shortcomings. Firstly, because this study is largely based on archival material from formal networks (mainly cooperatives and public institutes), the significance of informal networks (family ties, villages communities, etc.) are still unclear. Secondly, as the approach of this study mainly consisted of actor-based case studies, some parts of Dutch agriculture have not been extensively studied. Chapter 7 also presents possible pathways for future research. The success of Dutch agricultural innovation, this study shows, can be partly attributed to the high level of self-organization of the Dutch farming population. But where does this social capital come from? Why did the Netherlands see such a rapid and expansive growth in agricultural cooperatives? Comparable questions can be raised concerning the relatively large Dutch agro-food industry. How can the swift rise of the Dutch agro-food 
industry since the mid-nineteenth century be explained? In sum, a deeper understanding of the economic development of Dutch agriculture is still required. 


\section{SAMENVATTING}

De uitgave van het tijdschrift National Geographic van september 2017 had een artikel waarin verbaasd gevraagd werd hoe het toch kan dat Nederland, een klein, geürbaniseerd en dichtbevolkt land in West-Europa, de tweede voedselexporteur ter wereld is. Het antwoord op deze vraag wordt in dit artikel gevonden in de innovatie-kracht van de Nederlandse landbouw. Met drones, GPS en kunstmatige intelligentie meten en beïnvloeden Nederlandse akkerbouwers de groei en de gevraagde bemesting of bewatering op zeer gedetailleerd niveau, soms per vierkante meter of zelfs per plant. Waarom is Nederlandse landbouwinnovatie toonaangevend?

Deze studie verklaart het succes van Nederlandse landbouwinnovatie door naar haar historische wortels te kijken. Dit proefschrift stelt de vraag 'waarom en hoe konden Nederlandse boeren de meest innovatieve van Europa worden'? Deze vraag wordt beantwoord door de ontwikkeling van de Nederlandse akkerbouw tussen de jaren 1880 en de jaren 1960 te bestuderen. Dit proefschrift komt ten eerste tot de conclusie dat de voorwaarden in Nederland gunstig waren. Met hun gunstige ligging ten opzichte van de haven van Rotterdam (het belangrijkste handelsnetwerk van Europa) en de geïndustrialiseerde stedelijke agglomeraties in Duitsland en Groot-Brittannië konden Nederlandse boeren goed profiteren van de groeiende vraag naar hoogwaardige landbouwproducten. In combinatie met toenemende internationale competitie bracht dit de Nederlandse landbouwsector ertoe voortdurend te specialiseren en diversifiëren, wat ertoe leidde dat Nederlandse boeren zich bevonden aan de technologische frontier, de grens van wat op dat moment technologisch mogelijk was.

Ten tweede hielp de Nederlandse overheid de Nederlands landbouwsector met het verleggen van deze technologische frontier door agrarische research and development (R\&D) te stimuleren. Door de overheid gefinancierde onderzoeksinstellingen en landbouwvoorlichting waren belangrijke kanalen voor de uitwisseling van kennis en innovatie. Ten derde had de 
Nederlandse landbouwsector een hoge organisatiegraad ten opzichte van buitenlandse landbouwsectoren, iets wat geillustreerd wordt in de dichtheid en variatie aan landbouwcoöperaties in Nederland. Deze landbouwcoöperaties, en andere boerenorganisaties, faciliteerden een horizontale uitwisseling van kennis tussen boeren onderling. Publieke instellingen en boerenorganisaties stelden de Nederlandse landbouwsector gezamenlijk in staat actief te zijn in markt niches en buitenlandse innovaties af te stemmen op specifieke Nederlandse condities. De hoge specialisatie van de Nederlandse landbouwsector zorgde ervoor dat het importen van buitenlandse innovatie en kennis niet langer voldeed, waarna de Nederlandse landbouwsector, aan de hand van publieke instellingen en boerenorganisaties zelf kennis en innovatie ging ontwikkelen. Kortom, de publiek-private samenwerking verschafte de kennisuitwisseling die noodzakelijk was om actief te blijven op de technologische frontier, iets waar Nederlandse boeren zich tot op de dag van vandaag bevinden.

Met deze bevindingen levert dit proefschrift twee belangrijke. Ten eerste, daar waar landbouwinnovatie meestal wordt gezien als het gevolg van veranderende verhoudingen tussen land en arbeid of als het product van de noodzaak om ecologische beperkingen op te heffen, laat dit onderzoek zien dat ook de nabijheid van stedelijke markten een essentiële determinant is voor landbouwinnovatie. De noodzaak tot innoveren werd bij Nederlandse boeren vooral bepaald doordat ze opereerden dichtbij het centrum van het klassieke Von Thünen model (wat voorschrijft dat hoe dichter bij een stedelijke markt hoe intensiever, gespecialiseerder, en diverser de landbouw is) en doordat ze hun positie op Britse en Duitse markten moesten beschermen.

Ten tweede, een aantal landbouwhistorici stelt dat de kennisintensieve groei van landbouw in vele delen van de wereld tijdens de twintigste eeuw werd gedreven door een 'industrieel paradigma'. Dit paradigma schreef voor dat de landbouw de methoden, doelen, en productiviteitsgroei van de industriële sector diende te volgen. Dit paradigma werd verspreid 
onder boeren door landbouwexperts, waarmee de praktische kennis van de individuele boer over bijvoorbeeld lokale condities verloren zou zijn gegaan. Dit proefschrift laat echter zien dat de kennisintensieve groei van de Nederlandse landbouwsector, hoewel inderdaad gedreven door een soort 'industrieel paradigma', werd ondersteund door een aanzienlijk gedeelte van de Nederlandse agrarische bevolking, aangezien de intensivering van de Nederlandse landbouw een van de belangrijkste manieren was om het hoofd te bieden aan internationale competitie. Met een betere toegang tot kennis verbeterde de veerkracht van Nederlandse boeren, konden ze adequater op competitie en crises reageren en konden ze in hun levensonderhoud voorzien.

Het grootste gedeelte van dit onderzoek bestaat uit case studies waarin gekeken wordt naar specifieke innovaties of specifieke subsectoren binnen de Nederlandse landbouw. Deze case studies worden in een groter perspectief geplaatst met een analyse op nationaal niveau. Dit biedt ruimte voor een tweeledige vergelijking. Ten eerste worden bevindingen uit de Nederlandse casus vergeleken met voorbeelden uit België, Denemarken, Duitsland, Groot-Brittannië en in een enkel geval de Verenigde Staten. Ten tweede worden regio's binnen Nederland met elkaar vergeleken om een helder beeld te krijgen van regionale verscheidenheid in landbouwinnovatie. Door deze variatie aan methodes is dit onderzoek gebaseerd op een breed scala aan bronnen. Kwantitatieve gegevens bestaan uit handelsstatistieken en landbouwstatistieken, terwijl kwalitatieve gegevens zijn samengesteld uit landbouwkranten en archief materiaal, zoals notulen, jaarrapporten en correspondentie van bijvoorbeeld landbouwcoöperaties, onderzoeksinstituten, en andere actoren.

Hoofdstuk 1 is de introductie van dit proefschrift. Het bespreekt relevante literatuur, het reflecteert op de aanpak en methodologie en het biedt een afbakening van de gebruikte concepten. Het is van belang te benadrukken dat landbouwinnovatie op tenminste twee punten verschilt van innovatie in algemene zin. Ten eerste zijn landbouwinnovaties niet gemakkelijk 
te verplaatsen: ze zijn pas succesvol als ze goed worden afgestemd op lokale condities. Ten tweede zijn landbouwinnovaties vaak menselijke tussenkomsten in biologische processen, wat maakt dat landbouwinnovaties vaak nieuwe moeilijkheden veroorzaken. De vereiste afstemming op lokale condities en de nieuwe problemen die door landbouwinnovatie kunnen worden veroorzaakt geven de individuele boer een centrale positie in het innovatieproces. Omdat individuele boeren zelf weinig aan $R \& D$ kunnen doen, zijn ze sterk afhankelijk van leveranciers, onderzoeksinstituten, en andere externe partijen (of anders gezegd: landbouwinnovatie is 'leverancier-gedomineerd'). Hoofdstuk 1 benadrukt dan ook dat het slagen van landbouwinnovatie grotendeels wordt bepaald door de mate van kennisuitwisseling tussen individuele boeren en andere actoren.

Na de introductie plaatst Deel I van dit proefschrift de Nederlandse landbouwinnovatie in een bredere context. Hoofdstuk 2 bestudeert de internationale economische context en gebruikt inzichten uit literatuur gelieerd aan New Economic Geography om te laten zien dat de Nederlandse landbouw kon profiteren van de nabijheid van groeiende West Europese markten. Nederlandse boeren waren niet alleen gunstig gelegen ten opzichte van hun stedelijke consumenten, voornamelijk in Duitsland en Groot-Brittannië, maar hadden ook goede verbindingen met buitenlandse leveranciers van innovaties en inputs. Handelsdata laten zien dat de invoer van kunstmest en zaden explosief groeide vanaf de late negentiende eeuw. Echter, aanhoudende specialisatie en diversificatie brachten Nederlandse boeren bij de technologische frontier waardoor het importeren van buitenlandse kennis en innovatie niet langer voldeed. De Nederlandse landbouwsector werd gedwongen zijn eigen kennis en innovatie te ontwikkelen, waardoor Nederland geleidelijk veranderde in de exporteur van kennis en innovatie die het tegenwoordig nog is.

Hoofdstuk 3 behandelt de nationale politieke context. Waarom investeerde de Nederlandse overheid vanaf de vroege twintigste eeuw op grote schaal in landbouwonderwijs 
en $R \& D$, terwijl het in de negentiende eeuw nauwelijks een landbouwbeleid had gevoerd? Door middel van negentiende-eeuwse landbouwkranten, notulen van parlementszittingen, en overheidsdocumenten zoekt dit hoofdstuk het antwoord op deze vraag in het veranderende karakter van landbouwinnovatie. Nederlandse boeren hadden voor eeuwen gebruik gemaakt van innovaties en inputs die lokaal voor handen waren. Vanaf het midden van de negentiende eeuw werd de Nederlandse landbouw echter steeds afhankelijker van meststoffen, zaden, en diervoeding uit het buitenland. Omdat individuele boeren vaak te weinig kennis hadden over deze geïmporteerde inputs was hun onderhandelingspositie tegenover hun buitenlandse leveranciers zwak. De Nederlandse overheid wilde dit marktfalen oplossen door de toegang tot kennis te verbeteren, wat leidde tot groeiende overheidsfinanciering voor landbouwonderwijs, landbouwproefstations, en landbouwvoorlichting. 'Protectionisme van kennis' werd gezien als een goed alternatief voor het vermeden 'protectionisme van prijzen'.

Waar Deel I van dit proefschrift de economische en politieke context behandelt, gaat Deel II dieper in op verschillende casussen. Hoofdstuk 4 verklaart waarom Nederland veranderde van een relatief kleine gebruiker van kunstmest aan het eind van de negentiende eeuw naar één van de grootste gebruikers van kunstmest wereldwijd enkele decennia later. Hoewel een deel van het antwoord ligt in de verhouding tussen land en arbeid en in de voortgaande specialisatie en intensivering van de Nederlandse landbouw, benadrukt dit hoofdstuk dat de enorme toename in kunstmestgebruik tijdens de eerste decennia van de twintigste eeuw onwaarschijnlijk was geweest zonder een verbeterende kennisuitwisseling. Verschillende kanalen voor kennisuitwisseling speelden een rol, maar de landbouwvoorlichting door de overheid was cruciaal. Een internationale vergelijking laat zien dat het Nederlandse landbouwvoorlichtingssysteem één van de best ontwikkelde van die tijd was. Het groeiende aantal voorlichters verbeterde de kennisuitwisseling op lokaal niveau. Het voorbeeld van Jakob Elema, landbouwvoorlichter in Drenthe vanaf de jaren 1890 tot de jaren 1930, laat zien hoe 
individuele voorlichters lokale netwerken verbeterden en de lokale kennisuitwisseling professionaliseerden. Nederlandse landbouwvoorlichters hadden een blijvende invloed op lokale landbouw doordat ze succesvol lokale landbouwpers oprichtte en landbouwscholen opzetten.

Hoofdstuk 5 bespreekt de rol van landbouwcoöperaties. De casus van de suikerbietencoöperaties laat zien hoe landbouwcoöperaties een voordeel hadden als kennisnetwerken ten opzichte van andere kennisnetwerken, zoals netwerken opgezet door landbouwvoorlichters. Als lid van coöperaties waren individuele boeren onderdeel van een grotere groep, waarin ze gedwongen werden de productiemethoden van deze grotere groep te volgen en te participeren in de kennisuitwisseling die door deze grotere groep werd gefaciliteerd. Het archiefmateriaal van de suikerbietencoöperaties illustreert hoe deze coöperaties continu balanceerden tussen de individuele vrijheid van de afzonderlijke leden en de uniformiteit en kwaliteit van het eindproduct dat de coöperatie aan de market leverde. De suikerbietencoöperaties verhoogden de innovatie-capaciteit van hun leden door kennis te verspreiden en door toegang te verlenen tot bepaalde inputs, met name zaden. Vanaf de jaren 1920 organiseerden de suikerbietencoöperaties in Nederland ook gezamenlijk hun eigen $R \& D$, wat uiteindelijk zelfs uitmondde in de oprichting van hun eigen onderzoeksinstituut.

Hoofdstuk 6 legt uit waarom in Nederland het gebruik van kassen voor de productie van bloemen, groente, en fruit vanaf de jaren 1910 snel groeide, een ontwikkeling die de 'Nederlandse Glastuinbouw Revolutie' genoemd is. Een netwerk van tuinbouwveilingen en de gunstige ligging van het Zuid-Hollands glasdistrict (het Westland en De Kring) ten opzichte van de haven van Rotterdam zorgden ervoor dat Nederlandse tuinbouwproducten snel naar de Britse en Duitse consument gebracht kon worden, wat gezien de beperkte houdbaarheid van deze producten van groot belang was. De hoge concentratie van glastuinbouw in Zuid-Holland zorgde bovendien voor een hoge dichtheid aan proefvelden, studie clubs, leveranciers, en 
onderzoekers, wat kennisuitwisseling ten goede kwam. Dit verklaart, in combinatie met de bereidheid tot investeren van boerenleenbanken en overheidsfondsen, waarom de Nederlands glastuinbouw de grootste in haar soort werd en waarom het de wereldleider op het gebied van glastuinbouw-technologie is geworden.

Hoofdstuk 7, tenslotte, geeft een samenvatting van de belangrijkste bevindingen en de argumentatie van dit proefschrift. Dit hoofdstuk herhaalt kort de belangrijkste bijdrages van dit proefschrift en reflecteert op de twee belangrijkste tekortkomingen van dit onderzoek. Ten eerste is vrijwel uitsluitend archiefmateriaal van formele netwerken (coöperaties en publieke instellingen) gebruikt, waardoor informele netwerken (familie banden, dorpsgemeenschappen, etc.) onderbelicht zijn gebleven. Ten tweede bestaat de aanpak van dit onderzoek voor een groot gedeelte uit case studies, waardoor andere belangrijke onderdelen van de Nederlandse landbouw niet zijn onderzocht. Hoofdstuk 7 presenteert tenslotte nog opties voor vervolgonderzoek. Dit proefschrift heeft laten zien dat het succes van de Nederlandse landbouwinnovatie deels verklaard kan worden door de hoge organisatiegraad van de Nederlandse landbouwbevolking. Maar waar komt dit sociale kapitaal vandaan? Waarom was er zo'n snelle en grote groei van landbouwcoöperaties in Nederland? Vergelijkbare vragen kunnen gesteld worden bij de relatief grote voedingsindustrie in Nederland. Hoe kan de snelle opkomst van voedselverwerkende fabrieken sinds het midden van de negentiende eeuw verklaard worden? Kortom, een beter begrip van de economische ontwikkeling van de Nederlandse landbouw is nog altijd nodig. 


\section{REFERENCES}

Archival records

\section{Brabants Historisch Informatie Centrum}

181 Suikerfabriek Dinteloord, Zevenbergen, Roosendaal, 1908-1968, 1908-1968

\section{Drents Archief}

0154 Rijkslandbouwleraar/Rijkslandbouwconsulent voor Drenthe

\section{Groninger Archieven}

1435 Friesch-Groningsche Coöperatieve Beetwortelsuikerfabriek, 1913-1970

\section{Nationaal Archief}

NL-HaNA, Landbouwcommissie, 2.11.25

NL-HaNA, Directie van de Landbouw: Afdeling Akker- en Weidebouw, 2.11.01

\section{Regionaal Archief Dordrecht}

746, Suiker Unie te Puttershoek en haar rechtsvoorgangers

\section{Zeeuws Archief}

455, Eerste Nederlandsche Coöperatieve Beetwortelsuikerfabriek, Sas van Gent, 1882-1991

\section{Published Primary Sources}

Handelingen der Tweede Kamer (minutes of parliamentary debates)

Landbouw-courant (agricultural periodical)

Verslagen van den Landbouw (agricultural statistics)

Vriend van den Landman (agricultural periodical)

Statistiek van den In-, Uit-, en Doorvoer (Dutch national trade statistics) 


\section{Secondary Literature}

111 Jaar Statistiek in Tijdreeksen. The Hague: CBS, 2010.

Acemoglu, Daron. "Directed Technical Change," The Review of Economic Studies, 69, no. 4 (October 2002): 781-809.

Aerts, Remieg, Herman De Liagre Böhl, Piet De Rooy, and Henk Te Velde. Land van kleine gebaren. Een politieke geschiedenis van Nederland 1780-1990. 9th ed. Nijmegen/Amsterdam: SUN, 2009.

Anderson, J.L. Industrializing the Corn Belt. Agriculture, Technology, and Environment, 1945-1972. DeKalb: Northern Illinois University Press, 2009.

Auderset, Juri, and Peter Moser. Die Agrarfrage in der Industriegesellschaft. Wissenskulturen, Machtverhältnisse und natürliche Ressourcen in der agrarischindustriellen Wissensgesellschaft (1850-1950). Cologne: Böhlau Verlag, 2018.

Bakker, M. Ondernemerschap en vernieuwing. De Nederlandse bietsuikerindustrie. NEHAJaarboek voor economische, bedrijfs- en techniekgeschiedenis 3. Amsterdam: NEHA, 1989.

Baregheh, Anahita, Jennifer Rowley, and Sally Sambrook. "Towards a Multidisciplinary Definition of Innovation," Management Decision, 47, no. 8 (2009): 1323-39.

Barendse, J. 25 Jaar Tuinbouwonderwijs, -Voorlichting, -Onderzoek in Het Zuid-Hollands Glasdistrict 1924-1949, 1949.

Barendse, Jan. Hollands tuin. De Westlandse tuinbouw van vroeger tot nu. 's-Gravenzande: Drukkerij A. Sonneveld, 1951.

Berkers, Eric, and Frank W. Geels. "System Innovation through Stepwise Reconfiguration: The Case of Technological Transitions in Dutch Greenhouse Horticulture (19301980)," Technology Analysis \& Strategic Management, 23, no. 3 (2011): 227-47.

Bieleman, J. Boeren in Nederland. Geschiedenis van de landbouw 1500-2000. Amsterdam: Boom, 2008. . Boeren Op Het Drentse Zand, 1600-1910. Een Nieuwe Visie Op de "oude" Landbouw. AAG Bijdragen 29. Wageningen, 1987.

. "De landbouw in de periode 1850-1945." In Geschiedenis van Drenthe, edited by J. Heringa, D.P. Blok, M.G. Buist, and H.T. Waterbolk, 2nd ed., 547-90. Meppel: Boom, 1986.

. Five Centuries of Farming. A Short History of Dutch Agriculture 1500-2000.

Mansholt Publication Series 8. Wageningen: Wageningen Academic Publishers, 2010.

Bloemen, E., J. Kok, and J.L. Van Zanden. De Top 100 van Industriële Bedrijven in Nederland 1913-1990. The Hague: Adviesraad voor het Wetenschaps- en Technologiebeleid, 1993.

Blomme, Jan. The Economic Development of Belgian Agriculture 1880-1980. A Quantitative and Qualitative Analysis. Studies in Belgian Economic History 3. Brussel, 1992.

Boekholt, P.Th.F.M. "De nieuwste tijd 1850-1945." In Geschiedenis van Drenthe, edited by J. Heringa, D.P. Blok, M.G. Buist, and H.T. Waterbolk, 2nd ed., 591-678. Meppel: Boom, 1986.

Boersma, K. "Creating an Agricultural Research Network: Irradiation of Plants with Artificial Light at Philips Research in the 1930s," Business and Economic History On-Line, 2 (2004): 1-27.

Bosma, A.F., S. Van Veen, and H.J.M. De Vis. De ontwikkeling van de tuinbouwvestiging in het Zuidhollands Glasdistrict. LEI Studies 17. The Hague: Landbouw-Economisch Instituut, 1965.

Boulet, Michel. "1848, 1960: Two Laws for Agricultural Education in France. Essay on Comparisons between State's Methods of Intervention." In The State and Rural 
Societies. Policy and Education in Europe 1750-2000, edited by Nadine Vivier, 24758. Rural History in Europe 4. Turnhout: Brepols, 2008.

Boutkan, P.J. "Wat Deed Het Borgstellingsfonds," Bedrijfsontwikkeling, 7, no. 7/8 (August 1976): 513-17.

Brassley, P. "Agricultural Education, Training and Advice in the UK, 1850-2000." In The State and Rural Societies. Policy and Education in Europe 1750-2000, edited by Nadine Vivier, 259-74. Rural History in Europe 4. Turnhout: Brepols, 2008.

Brock, William H. Justus von Liebig: The Chemical Gatekeeper. Cambridge: Cambridge University Press, 1997.

Carnevali, Francesca. "Social Capital and Trade Associations in America, c. 1860-1914: A Microhistory Approach," Economic History Review, 64, no. 3 (August 2011): 905-28.

Christensen, Jens. Rural Denmark, 1750-1980. Translated by Else Buchwald Christensen. Copenhagen: The Central Co-operative Committee of Denmark, 1983.

Clement, Marcel. Transport en economische ontwikkeling. Analyse van de modernisering van het transportsysteem in de provincie Groningen (1800-1914). Groningen: Wolters, 1994.

Collins, E.J.T., ed. 1850-1914. The Agrarian History of England and Wales 7. Cambridge: Cambridge University Press, 2000.

Cortat, Alain. "How Cartels Stimulate Innovation and R\&D: Swiss Cable Firms, Innovation and the Cartel Question," Business History, 51, no. 5 (September 2009): 754-69.

Crafts, Nicholas, and Abay Mulatu. "How Did the Location of Industry Respond to Falling Transport Costs in Britain Before World War I?," Journal of Economic History, 66, no. 3 (September 2006): 575-607.

David, Paul A. "The Mechanization of Reaping in the Ante-Bellum Midwest." In Industrialization in Two Systems: Essays in Honor of Alexander Gerschenkron, edited by Henry Rosovsky, 3-39. New York: John Wiley \& Sons, 1966.

De Haan, H. "The History of the Plant Breeding Institute I.v.P. 1912-1962," Euphytica, no. 12 (1963): 130-36.

De Vries, Jan. European Urbanization 1500-1800. Cambridge, MA: Harvard University Press, 1984.

De Vries, Jan, and Ad van der Woude. The First Modern Economy: Success, Failure, and Perseverance of the Dutch Economy, 1500-1815. Cambridge: Cambridge University Press, 1997.

De Wit, W. "Twintig jaar Borgstellingsfonds voor de Landbouw (1951-1971)," Bedrijfsontwikkeling, 3, no. 10 (Oktober 1972): 871-73.

De Zeeuw, A. "25 Jaar Borgstellingsfonds Voor de Landbouw," Bedrijfsontwikkeling, 7, no. 7/8 (August 1976): 507-8.

Dekker, H. Landbouwonderwijs in Drenthe. Kwantitatieve en kwalitatieve analyse van de belangstelling van de boerenzoons voor het landbouwonderwijs. LandbouwEconomisch Instituut Afdeling Streekonderzoek 361. The Hague: LandbouwEconomisch Instituut, 1961.

Diser, Lyvia. "Laboratory versus Farm: The Triumph of Laboratory Science in Belgian Agriculture at the End of the Nineteenth Century," Agricultural History, 86, no. 1 (Winter 2012): 31-54.

Dolman, M.A., G.D. Jukema, and P. Ramaekers, eds. De Nederlandse landbouwexport in 2018 in breder perspectief. Wageningen Economic Research Rapport 2019-001. Wageningen: Wageningen Economic Research, 2019.

Epstein, S.R., and Maarten Prak. "Introduction: Guilds, Innovation, and the European Economy, 1400-1800." In Guilds, Innovation, and the European Economy, 1400- 
1800, edited by S.R. Epstein and Maarten Prak, 1-24. Cambridge: Cambridge University Press, 2008.

Federico, Giovanni. Feeding the World. An Economic History of Agriculture, 1800-2000. Second Edition. Princeton: Princeton University Press, 2009.

Feldman, Maryann P. "Why Location Matters for Innovative Activity." In The Geography of Innovation, 13-28. Economics of Science, Technology and Innovation 2. Dordrecht: Kluwer Academic Publishers, 1994.

Feldman, Maryann P., and Nadine Massard. "Location, Location, Location: Institutions and Systems in the Geography of Innovation." In Institutions and Systems in the Geography of Innovation, 1-20. Economics of Science, Technology and Innovation 25. Dordrecht: Kluwer Academic Publishers, 2002.

Fernández, Eva. "Selling Agricultural Products: Farmers' Co-Operatives in Production and Marketing, 1880-1930," Business History, 56, no. 4 (2014): 547-68.

Filarski, Ruud, and Gijs Mom. Van transport naar mobiliteit. De transportrevolutie, 18001900. Zutphen: Walburg Pers, 2008.

Finlay, Mark Russell. "Science, practice, and politics: German agricultural experiment stations in the nineteenth century." Iowa State University, 1992.

Fitzgerald, Deborah. Every Farm a Factory. The Industrial Ideal in American Agriculture. New Haven and London: Yale University Press, 2003.

Folley, R.R.W. The Role of Credit in Business Growth: An Example from the Netherlands. An Examination of Dutch Glasshouse Growers' Use of Agricultural Credit Banks and Other Credit Sources during the Expansion Period 1952-1965. Ashford: Wye College, 1968.

Frankema, Ewout. "Kapitaalvorming in infrastructuur in Nederland 1900-1970." Rijksuniversiteit Groningen, 2001.

Frankema, Ewout, Pieter Woltjer, and Jan-Pieter Smits. "Changing Economic Leadership. A New Benchmark of Sector Productivity in the United States and Western Europe, ca. 1910," Low Countries Journal for Social and Economic History, 10, no. 3 (2013): 80113.

Gijsberts, L. "De vraag naar Westlandse groenten en fruit." In Van Crisis tot Kracht. Gedenkboek ter gelegenheid van het vijfenzeventig-jarig bestaan van de Bond Westland, 133-54. Naaldwijk: Bond Westland, 1964.

Goddard, Nicholas. Harvests of Change. The Royal Agricultural Soceity of England 18381988. London: Quiller Press, 1988.

Godin, Benoit. Models of Innovation. The History of an Idea. Cambridge, MA: The MIT Press, 2017.

Goossens, Martine, and Koen Dries. "Twee vroege voorbeelden van agro-business: de suikerbietindustrie en de graanstokerijen." In Nijver België. Het industriële landschap omstreeks 1850, edited by Bart Van der Herten, Michel Oris, and Jan Rogiers, 265-76. Ortelius Series. MIM, 1995.

Goudswaard, N.B. Agrarisch onderwijs in Nederland, 1783-1983. Culemborg: Educaboek, 1986.

Grantham, George. "The Shifting Locus of Agricultural Innovation in Nineteenth-Century Europe: The Case of the Agricultural Experiment Stations." In Technique, Spirit and Form in the Making of the Modern Economies: Essays in Honor of William N. Parker, edited by Gary Saxonhouse and Gavin Wright, 191-214. Research in Economic History 3. Greenwich and London: Jai Press, 1984.

Grigg, D.B. Population Growth and Agrarian Change. An Historical Perspective. Cambridge Geographical Studies 13. Cambridge: Cambridge University Press, 1980. 
Groot, Frans. Roomsen, rechtzinnigen en nieuwlichters. Verzuiling in een Hollandse plattelandsgemeente, Naaldwijk 1850-1930. Hilversum: Verloren, 1992.

Groote, Peter. "Kapitaalvorming in infrastructuur in Nederland 1800-1913." Rijksuniversiteit Groningen, 1995.

Grooters, J.W. "Tuinbouw onder glas en varkenshouderij. Vergelijking tussen twee landbouwkennissystemen in Nederland." Landbouwkundig Tijdschrift 103, no. 5 (1991): 27-29.

Guinnane, T.W. "Cooperatives as Information Machines: German Rural Credit Cooperatives, 1883-1994," Journal of Economic History, 61, no. 2 (2001): 366-89.

Harmsen, K. Het Instituut voor Bodemvruchtbaarheid 1890-1990. Haren: Instituut voor Bodemvruchtbaarheid, 1990.

Harwood, Jonathan. Europe's Green Revolution and Others Since. The Rise and Fall of Peasant-Friendly Plant Breeding. Routledge Explorations in Economic History 56. London and New York: Routledge, 2012. . "Research and Extension in Political Context: Rural Unrest and the Origins of the Prussian Chambers of Agriculture." In The State and Rural Societies. Policy and Education in Europe 1750-2000, edited by Nadine Vivier, 135-57. Rural History in Europe 4. Turnhout: Brepols, 2008.

- "Review Die Agrarfrage in Der Industriegesellschaft: Wissenskulturen, Machtverhaeltnisse Und Natürliche Ressourcen in Der Agrarisch-Industriellen Wissensgesellschaft (1850-1950) by Auderset and Moser," Agricultural History, 93, no. 1 (Winter 2019): 191-93.

- Technology's Dilemma. Agricultural Colleges between Science and Practice in Germany, 1860-1934. Bern: Peter Lang, 2005.

. "Why Did Nineteenth-Century States Establish Agricultural Research Stations? The Origins of the South German Plant-Breeding Stations c. 1900." In Integration through Subordination. The Politics of Agricultural Modernisation in Industrial Europe, edited by Peter Moser and Tony Varley, 245-66. Rural History in Europe 8. Turnhout: Brepols, 2013.

Hayami, Yujiro, and Vernon W. Ruttan. Agricultural Development. An International Perspective. 2nd ed. Baltimore: The Johns Hopkins University Press, 1991.

Heijbroek, Willem, and Jurgen Maassen, eds. Zoete invallen. 75 jaar onderzoek en voorlichting voor de Nederlandse suikerbietenteelt. Bergen op Zoom: Stichting IRS, 2005.

Henriksen, Ingrid. “Avoiding Lock-in: Cooperative Creameries in Denmark, 1882-1903,” European Review of Economic History, 3, no. 1 (April 1999): 57-78.

Henriksen, Ingrid, and Morten Hviid. "Diffusion of New Technology and Complementary Best Practice: A Case Study," European Review of Economic History, 9 (2005): 36597.

Henriksen, Ingrid, Markus Lampe, and Paul Sharp. "The Role of Technology and Institutions for Growth: Danish Creameries in the Late Nineteenth Century," European Review of Economic History, 15, no. 3 (2011): 475-93.

Het landbouwkrediet in Nederland. Rapport van de Commissie Landbouwkrediet. The Hague: Cedo Nulli, 1960.

Hicks, J.R. The Theory of Wages. 2nd ed. London: Macmillan, 1963.

Homburg, Ernst. Groeien door kunstmest. DSM Agro 1929-2004. Hilversum: Verloren, 2004.

Jones, Geoffrey, and Walter A. Friedman. "Business History: Time for Debate," Business History Review, 85, no. 1 (March 2011): 1-8.

Jones, Peter M. Agricultural Enlightenment. Knowledge, Technology, and Nature, 1750-1840. Oxford: Oxford University Press, 2016. 
Kemmers, W., and L. Gijsberts. 75 jaar Centraal Bureau van de Tuinbouwveilingen in Nederland. Vianen: Habo Dacosta, 1992.

Klein, Alexander, and Nicholas Crafts. "Making Sense of the Manufacturing Belt: Determinants of US Industrial Location, 1880-1920," Journal of Economic Geography, 2011, 1-33.

Klemann, H.A.M. "Tussen Reich en Empire. De economische betrekkingen van Nederland met zijn belangrijkste handelspartners. Duitsland, Groot Brittannië en België en de Nederlandse handelspolitiek, 1929-1936.” Erasmus University Rotterdam, 1990.

Knaap, Dorien. "Voor geld is altijd wel een plaats te vinden": de firma W.A. Scholten (18411892) De eerste Nederlandse industriële multinational. Groningse Historische Reeks 27. Assen: Koninklijke Van Gorcum, 2004.

Knibbe, Merijn. Agriculture in the Netherlands 1851-1950. Production and Institutional Change. Amsterdam: NEHA, 1993.

. "Feed, Fertilizer and Agricultural Productivity in the Netherlands, 1880-1930," Agricultural History, 74, no. 1 (2000): 39-57.

. "Landbouwproductie en -productiviteit, 1807-1997." In Nationaal goed. Feiten en cijfers over onze samenleving, (ca.) 1800-1999, edited by Ronald Van der Bie and Pit Dehing, 37-60. Amsterdam: Stichting beheer IISG, 1999.

Knibbe, Merijn, and Marijn Molema. "Institutionalisation of Knowledge-Based Growth: The Case of the Dutch-Frisian Dairy Sector (1895-1950)," Rural History: Economy, Society, Culture, 29, no. 2 (October 2018): 217-35.

Koning, Niek. The Failure of Agrarian Capitalism. Agrarian Politics in the United Kingdom, Germany, the Netherlands and the USA, 1846-1919. London and New York: Routledge, 1994.

Koopman, Gerrie. Van Hall tot Heden. Tachtig jaar hoger agrarisch onderwijs in Groningen (1912-1992). Groningen: REGIO-PRojekt Uitgevers, 1992.

Koppel, Bruce M., ed. Induced Innovation Theory and International Agricultural Development. A Reassessment. Baltimore: The Johns Hopkins University Press, 1995.

Kopsidis, Michael, and Heinrich Hockmann. "Technical Change in Westphalian Peasant Agriculture and the Rise of the Ruhr, circa 1830-1880," European Review of Economic History, 14, no. 2 (August 2010): 209-37.

Kopsidis, Michael, and Nikolaus Wolf. "Agricultural Productivity across Prussia during the Industrial Revolution: A Thünen Perspective," Journal of Economic History, 72, no. 3 (September 2012): 634-70.

Krohn, W., and W. Schäfer. "The Origins and Structure of Agricultural Chemistry." In Perspectives on the Emergence of Scientific Disciplines, edited by G. Lemaine, R. Macleod, M.J. Mulkay, and P. Weingart, 27-52. Maison Des Sciences de l'Homme, Paris Publications 4. The Hague: Mouton \& Co., 1976.

Krugman, P.R. "Increasing Returns and Economic Geography," Journal of Political Economy, no. 99 (1991): 483-99.

Krugman, P.R., and A.J. Venables. "Globalization and the Inequality of Nations," Quarterly Journal of Economics, 4, no. 110 (1995): 857-80.

Krugman, P.R., A.J. Venables, and Fujita Masahisa. The Spatial Economy: Cities, Regions, and International Trade. Cambridge, MA: MIT Press, 1999.

Lampe, Markus, and Paul Sharp. A Land of Milk and Butter. How Elites Created the Modern Danish Dairy Industry. Chicago: University of Chicago Press, 2018. . "A Quest for Useful Knowledge. The Early Development of Agricultural Accounting in Denmark and Northern Germany," Accounting History Review, 27, no. 1 (2017): 73-99. 
Landes, David S. The Wealth and Poverty of Nations. Why Some Are so Rich and Some so Poor. New York and London: W.W. Norton and Company, 1999.

Maat, Harro. "Het innovatiesysteem voor de Nederlandse landbouw," NEHA-Jaarboek voor economische, bedrijfs- en techniekgeschiedenis, 66 (2003): 233-62.

. "Science Cultivating Practice. A History of Agricultural Science in the Netherlands and Its Colonies 1863-1986." Wageningen University, 2001.

Maltha, D.J. Honderd jaar landbouwkundig onderzoek in Nederland 1876-1976.

Wageningen: Centrum voor landbouwpublikaties en landbouwdocumentatie, 1976.

Martinelli, Pablo. "Von Thünen South of the Alps: Access to Markets and Interwar Italian Agriculture," European Review of Economic History, 18, no. 2 (May 2014): 107-43.

Mathijsen, A., ed. The Origins of Veterinary Schools in Europe - a Comparative View. Utrecht, 1997.

McCloskey, Deirdre N. Bourgeois Dignity: Why Economics Can't Explain the Modern World. Chicago and London: University of Chicago Press, 2010.

- Bourgeois Equality. How Ideas, Not Capital or Institutions, Enriched the World. Chicago and London: University of Chicago Press, 2016.

- The Bourgeois Virtues: Ethics for an Age of Commerce. Chicago and London: University of Chicago Press, 2006.

Mitchell, B.R. European Historical Statistics 1750-1970. London and Basingstoke: Macmillan, 1975.

Mokyr, Joel. A Culture of Growth: The Origins of the Modern Economy. Princeton and Oxford: Princeton University Press, 2017.

-. The Enlightened Economy: An Economic History of Britain 1700-1860. New Haven and London: Yale University Press, 2012.

- The Gifts of Athena. Historical Origins of the Knowledge Economy. Princeton: Princeton University Press, 2002.

Mom, Gijs, and Ruud Filarski. Van transport naar mobiliteit. De mobiliteitsexplosie, 18952005. Zutphen: Walburg Pers, 2008.

Moser, Peter, Juri Auderset, and Beat Bächi. "Die agrarisch-industrielle Wissensgesellschaft im 19./20. Jahrhundert: Akteure, Diskurse, Praktiken." In Geschichte im virtuellen Archiv. Das Archiv für Agrargeschichte als Zentrum der Geschichtsschreibung zur ländlichen Gesellschaft, edited by Beat Brodbeck, Martina Ineichen, and Thomas Schibli, 21-38. Studien und Quellen zur Agrargeschichte 3. Baden: Hier und Jetzt Verlag, 2012.

Nicholson, Julian. The Dutch Glasshouse Industry. An Economic History. Wye: Wye College Press, 1995.

Offringa, C. Van Gildestein naar Uithof. 150 jaar diergeneeskundig onderwijs in Utrecht. Vol. Deel I: 's Rijksveeartsenijschool (1821-1918) Veeartsenijkundige Hoogeschool (1918-1925). Utrecht: Rijksuniversiteit te Utrecht. Faculteit der diergeneeskunde, 1971.

Ogilvie, Sheilagh. The European Guilds. An Economic Analysis. Princeton and Oxford: Princeton University Press, 2019.

Olmstead, Alan L. "The Mechanization of Reaping and Mowing in American Agriculture, 1833-1870," Journal of Economic History, 35, no. 2 (1975): 327-52.

Olmstead, Alan L., and Paul W. Rhode. "Conceptual Issues for the Comparative Study of Agricultural Development." In Agriculture and Economic Development in Europe Since 1870, edited by Pedro Lains and Vicente Pinilla, 27-51. London: Routledge, 2009.

Creating Abundance. Biological Innovation and American Agricultural

Development. Cambridge: Cambridge University Press, 2008. 
"Induced Innovation in American Agriculture: A Reconsideration," Journal of Political Economy, 101, no. 1 (1993): 100-118.

. "The Red Queen and the Hard Reds: Productivity Growth in American Wheat, 18001940," Journal of Economic History, 62, no. 4 (2002): 929-66.

Pan-Montojo, Juan. "Landowners, Technicians and Associations: The Formation of the Agricultural Public Institutions in Spain, 1847-1936." In The State and Rural Societies. Policy and Education in Europe 1750-2000, edited by Nadine Vivier, 11134. Rural History in Europe 4. Turnhout: Brepols, 2008.

Pavitt, Keith. "Sectoral Patterns of Technical Change: Towards a Taxonomy and a Theory," Research Policy, 13, no. 6 (1984): 343-73.

Pazzagli, Rossano. "From Private Initiative to State Intervention: The Origins of Agricultural Education in Italy." In The State and Rural Societies. Policy and Education in Europe 1750-2000, edited by Nadine Vivier, 231-46. Rural History in Europe 4. Turnhout: Brepols, 2008.

Perkins, J.A. "The Agricultural Revolution in Germany 1850-1914," Journal of European Economic History, 10 (1981): 71-118.

. "The Organisation of German Industry, 1850-1930: The Case of Beet-Sugar

Production," Journal of European Economic History, 19 (1990): 549-72.

Persson, Torsten, ed. Nobel Lectures, Economics 1991-1995. Singapore: World Scientific Publishing, 1997.

Pilat, Dirk. Dutch Agricultural Export Performance (1846-1926). Historia Agriculturae 19. Groningen: Nederlands Agronomisch-Historisch Instituut, 1989.

Planas, Jordi. "The Emergence of Winemaking Cooperatives in Catalonia," Business History, 58 (2016): 264-82.

Plantenberg, P., ed. 100 jaar veilingen in de tuinbouw. Amstelveen: ACT, 1987.

Porceddu, E., and R. Rabbinge. "Role of research and education in the development of agriculture in Europe," European Journal of Agronomy, no. 7 (1997): 1-13.

Priester, Peter. "Boeren met machines." In Techniek in Nederland in de twintigste eeuw. Deel III: Landbouw, voeding, edited by H.W. Lintsen, 64-71. Zutphen: Walburg Pers, 2000.

- Geschiedenis van de Zeeuwse landbouw circa 1600-1910. AAG Bijdragen 37.

Wageningen, 1998.

Roessingh, H.K. "Tobacco Growing in Holland in the Seventeenth and Eighteenth Centuries:

A Case Study of the Innovative Spirit of Dutch Peasants," The Low Countries History

Yearbook: Acta Historiae Neerlandicae, no. 11 (1978).

Rogers, Everett M. Diffusion of Innovations. 5th ed. New York: Free Press, 2003.

Rommes, Ronald. Voor en door boeren? De opkomst van het coöperatiewezen in de Nederlandse landbouw vóór de Tweede Wereldoorlog. Hilversum: Verloren, 2014.

Rosenberg, Nathan. Inside the Black Box: Technology and Economics. Cambridge: Cambridge University Press, 1982.

Rosés, Joan R. "Why Isn't the Whole of Spain Industrialized? New Economic Geography and Early Industrialization, 1797-1910," Journal of Economic History, 63, no. 4 (December 2003): 995-1022.

Ruttan, Vernon W. Technology, Growth and Development: An Induced Innovation Perspective. New York: Oxford University Press, 2001.

Sangers, W.J. De ontwikkeling van de Nederlandse tuinbouw (tot het jaar 1930). Zwolle: Tjeenk Willink, 1952.

Saxena, M.L. Agricultural Credit in the Netherlands. The Hague: Institute of Social Studies, 1962. 
Schling-Brodersen, Ursula. Entwicklung und Institutionalisierung der Agrikulturchemie im 19. Jahrhundert: Liebig und die landwirtschaftlichen Versuchstationen.

Braunschweiger Veröffentlichungen zur Geschichte der Pharmazie und der

Naturwissenschaften 31. Braunschweig: Technische Universität, 1989.

Schumpeter, Joseph A. The Theory of Economic Development. An Inquiry into Profits, Capital, Credit, Interest, and the Business Cycle. Translated by Redvers Opie. 3rd ed. Harvard Economic Studies 46. Cambridge, MA: Harvard University Press, 1949.

Schuurman, Anton. "Agricultural Policy and the Dutch Agricultural Institutional Matrix during the Transition from Organized to Disorganized Capitalism." In Integration through Subordination. The Politics of Agricultural Modernisation in Industrial Europe, edited by Peter Moser and Tony Varley, 65-84. Rural History in Europe 8. Turnhout: Brepols, 2013.

. "The Construction of Dutch Agriculture Inc: From Liberal Capitalism to Organized Capitalism." Lisbon, 2008.

Segers, Yves, and Leen van Molle. Leven van het land. Boeren in België 1750-2000. Leuven: Davidsfonds, 2004.

Slicher van Bath, B.H. De agrarische geschiedenis van West-Europa, 500-1850. Sixth Edition. Utrecht: Spectrum, 1987.

. The Agrarian History of Western Europe, AD 500-1850. Translated by Olive Ordish. London: Edward Arnold (Publishers) Ltd, 1963.

- Yield Ratios, 810-1820. AAG Bijdragen 10. Wageningen, 1963.

Sluyterman, Keetie, Joost Dankers, Jos van der Linden, and Jan Luiten van Zanden. Het coöperatieve alternatief. Honderd jaar Rabobank 1898-1998. The Hague: Sdu Uitgevers, 1998.

Sluyterman, Keetie E. Driekwart eeuw CSM. Cash flow, strategie en mensen. CSM, 1995.

Smil, Vaclav. Enriching the Earth. Fritz Haber, Carl Bosch, and the Transformation of World Food Production. Cambridge, MA: The MIT Press, 2001.

Smits, Jan-Pieter. "Technological Change, Institutional Development and Economic Growth in Dutch Agriculture, 1870-1939." In Agriculture and Economic Development in Europe Since 1870, edited by Pedro Lains and Vicente Pinilla, 97-116. London: Routledge, 2009.

Smits, Ruud. "Innovation Studies in the 21st Century: Questions from a User's Perspective," Technological Forecasting and Social Change, 69, no. 9 (December 2002): 861-83.

Snelders, H.A.M. "Landbouw en scheikunde in Nederland in de vóór-Wageningse periode (1800-1876)," AAG Bijdragen, 24 (1984).

Spinage, C.A. Cattle Plague. A History. New York: Kluwer Academic/Plenum Publishers, 2003.

Terlouw, Frida. "De geschiedenis van de bietsuikerindustrie in Nederland en van de Coöperatieve Suikerfabriek en Raffinaderij g.a. Puttershoek 1912-1966 in het bijzonder met inachtneming van de overheidspolitiek en de verhouding tussen de coöperatieve en de particuliere industrie." Nederlandse Economische Hogeschool, 1969.

Thirtle, Colin G., and Vernon W. Ruttan. The Role of Demand and Supply in the Generation and Diffusion of Technical Change. 2nd ed. London and New York: Routledge, 2001.

Tracy, Michael. Government and Agriculture in Western Europe, 1880-1988. Third Edition. New York: Harvester Wheatsheaf, 1989.

Uekötter, Frank. Die Wahrheit ist auf dem Feld. Eine Wissensgeschichte der deutschen Landwirtschaft. 3rd ed. Umwelt und Gesellschaft 1. Göttingen: Vandenhoeck \& Ruprecht, 2012. 
Van den Ban, A.W. Boer en landbouwonderwijs. De landbouwkundige ontwikkeling van de Nederlandse boeren. Bulletin Afdeling Sociologie en Sociografie van de Landbouwhogeschool 8. Wageningen: Afdeling Sociologie en Sociografie van de Landbouwhogeschool, 1957.

. "Hoeveel boeren hebben landbouwonderwijs gevolgd?" Landbouwvoorlichting, June 1956, 314-17.

Van den Muijzenberg, Erwin W.B. A History of Greenhouses. Wageningen: Institute for Agricultural Engineering, 1980.

Van der Haar, J. De geschiedenis van de Landbouwuniversiteit Wageningen. Deel I: van school naar hogeschool, 1873-1945. Wageningen: Landbouwuniversiteit Wageningen, 1993.

Van der Laarse, R. A Nation of Notables: Class, Politics and Religion in the Netherlands in the Nineteenth Century. Occasional Papers in the Contemporary History and Politics 3. Salford: European Studies Research Institute, 2000.

Van der Poel, J.M.G. Het Landbouwonderwijs in Nederland tot 1918. Wageningen: Centrum voor landbouwpublikaties en landbouwdocumentatie, 1976.

- Honderd jaar landbouwmechanisatie in Nederland. Agronomisch-Historische Bijdragen 11. Wageningen: H. Veenman \& Zonen N.V., 1967.

Van Doesburg, Jan, Elke Kooistra, Cor Vonk Noordegraaf, and Willem van Winden, eds. Honderd jaar praktijkonderzoek voor de glastuinbouw. Meten = weten. Doetinchem: Elsevier, 1999.

Van Emmenes, A. Kikkerdorp en de Kikkerdorpers. Geldersche Historische Novelle, bewerkt in de Strafgevangenis te Nieuwer-Amstel. Vol. 3. Bibliotheek voor Ontspanning en Ontwikkeling 7. Amsterdam: De Roode Bibliotheek, 1897.

Van Lennep, M.B. "De geschiedenis van het landbouwkundig onderzoek in Nederland," TNO Nieuws, no. 14 (1959): 103-9.

Van Molle, Leen. "Kulturkampf in the Countryside. Agricultural Education, 1800-1940: A Multifaceted Offensive." In Land, Shops and Kitchens. Technology and the Food Chain in Twentieth-Century Europe, edited by Carmen Sarasua, Peter Scholliers, and Leen Van Molle, 139-69. CORN Publication Series 7. Turnhout: Brepols, 2005. - 100 jaar Ministerie van Landbouw. Het Belgisch landbouwbeleid in de wisselwerking tussen economische en sociale toestanden, politiek en administratie 1884-1984, Agricontact, koerier van het Ministerie van Landbouw, 154 (September 1984): 1-141.

Van Rooij, Arjan, Eric Berkers, Mila Davids, and Frank Veraart. "National Innovation Systems and International Knowledge Flows: An Exploratory Investigation with the Case of the Netherlands," Technology Analysis \& Strategic Management, 20, no. 2 (2008): 149-68.

Van Stuijvenberg, J.H. De ontstaansgronden van de landbouwcoöperatie in her-overweging. Den Haag: Nationale Coöperatieve Raad voor Land- en Tuinbouw, 1977.

- Het Centraal Bureau. Een coöperatief krachtveld in de Nederlandse landbouw 18991949. Rotterdam, 1949.

Van Valen, Leigh. “A New Evolutionary Law,” Evolutionary Theory, 1 (1973): 1-30.

Van Zanden, Jan Luiten, and Maarten Prak. Nederland en het poldermodel. De economische en sociale geschiedenis van Nederland, 1000-2000. Amsterdam: Bert Bakker, 2013.

Van Zanden, J.L. De economische ontwikkeling van de Nederlandse landbouw in de negentiende eeuw, 1800-1914. AAG Bijdragen 25. Wageningen, 1985.

. "Mest en ploeg." In Geschiedenis van de techniek in Nederland. De wording van een moderne samenleving 1800-1890. Deel I: Techniek en modernisering. Landbouw en voeding, edited by H.W. Lintsen, 53-69. Zutphen: Walburg Pers, 1992. 
. "The Development of Agricultural Productivity in Europe 1500-1800," NEHAJaarboek voor economische, bedrijfs- en techniekgeschiedenis, 61 (1998): 66-85.

- The Economic History of the Netherlands 1914-1915. A Small Open Economy in the "long" Twentieth Century. Contemporary Economic History of Europe. London and New York: Routledge, 1998.

. The First Green Revolution. The Growth of Production and Productivity in European Agriculture 1870-1914. Research Memorandum 1988-42. Amsterdam: Vrije Universiteit, 1988.

- "The First Green Revolution: The Growth of Production and Productivity in European Agriculture, 1870-1914," Economic History Review, 44, no. 2 (1991): 21539.

Van Zanden, J.L., and R.T. Griffiths. Economische geschiedenis van Nederland in de 20e eeuw. Utrecht: Het Spectrum, 1989.

Van Zanden, J.L., and Arthur van Riel. The Strictures of Inheritance: The Dutch Economy in the Nineteenth Century. Translated by Ian Cressie. Princeton, NJ: Princeton University Press, 2004.

Vedder, A. "Prof. Ir. Jacob Elema," Nieuwe Drentse Volksalmanak, 75 (1957): 9-22.

Veldman, Hans, Eric van Royen, and Frank Veraart. A Powerful Partner in Dutch Agriculture and Horticulture. The History of Cebeco-Handelsraad, 1899-1999. Rotterdam: Foundation for History of Technology, 1999.

Verkaik, A.P. Organisatiestructuur landbouwkundig onderzoek en achtergronden van haar totstandkoming. The Hague: Nationale Raad voor Landbouwkundig onderzoek TNO, 1971.

Vermeulen, W.H. Den Haag en de landbouw. Keerpunten in het negentiende-eeuwse landbouwbeleid. Staatkunde en Burgerschap 5. Assen: Van Gorcum, 1966.

Vijverberg, A.J. Glastuinbouw in ontwikkeling. Beschouwingen over de sector en de beïnvloeding ervan door de wetenschap. Delft: Eburon, 1996.

Vivier, Nadine. "European Agricultural Networks, 1750-1850: A View from France." In $A$ Common Agricultural Heritage? Revising French and British Rural Divergence., edited by John Broad, 23-36. The Agricultural History Review Supplement Series 5. Exeter: British Agricultural History Society, 2009.

Whetham, Edith H., ed. 1914-1939. The Agrarian History of England and Wales 8. Cambridge: Cambridge University Press, 1978.

Wieland, Thomas. "Wir beherrschen den pflanzlichen Organismus besser,..." Wissenschaftliche Pflanzenzüchtung in Deutschland 1889-1945. Abhandlungen und Berichte, Neue Folge 20. München: Deutsches Museum, 2004.

Wolf, Nikolaus. "Endowments vs Market Potential: What Explains the Relocation of Industry after the Polish Reunification in 1918?," Explorations in Economic History, no. 44 (2007): 22-42.

Zuurbier, P.J.P. "De besturing en organisatie van de Landbouwvoorlichtingsdienst." Landbouwhogeschool Wageningen, 1984.

- De relaties tussen onderzoek, voorlichting en de boer. Den Haag: Directie Bedrijfsstructurele Aangelegenheden, 1978. 


\section{Harm Zwarts \\ Wageningen School of Social Sciences (WASS) \\ Completed Training and Supervision Plan}

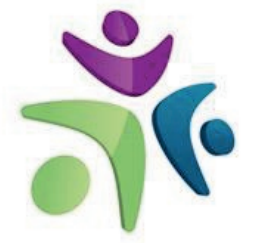

Wageningen School

of Social Sciences

\begin{tabular}{|c|c|c|c|}
\hline Name of the learning activity & Department/Institute & Year & ECTS* \\
\hline \multicolumn{4}{|l|}{ A) Project related competences } \\
\hline $\begin{array}{l}\text { Basic Training in Economic and Social } \\
\text { History }\end{array}$ & N.W. Posthumus Institute & $2016-2018$ & 17 \\
\hline Datini-ESTER Advanced Seminar & ESTER/Datini & 2017 & 2 \\
\hline WASS research proposal & WASS & 2016 & 6 \\
\hline \multicolumn{4}{|l|}{ B) General research related competences } \\
\hline Introduction course & WASS & 2016 & 1 \\
\hline Scientific Writing course & Wageningen in'to Languages & 2016 & 1.8 \\
\hline Organizing a panel & $\begin{array}{l}\text { Rural History Conference (Paris, } \\
\text { Sept. 2019) }\end{array}$ & 2019 & 0.5 \\
\hline Organizing a panel & $\begin{array}{l}\text { Rural History Conference (Leuven, } \\
\text { Sept. 2017) }\end{array}$ & 2017 & 0.5 \\
\hline $\begin{array}{l}\text { 'Agricultural Innovation and State-Led } \\
\text { Consultancy: the Diffusion of Useful } \\
\text { Chemical Knowledge among Dutch Farmers, } \\
\text { c. 1890-1950' }\end{array}$ & $\begin{array}{l}\text { Posthumus Congress (Gent, May } \\
\text { 2019); Oxford Social and Economic } \\
\text { History Graduate Workshop } \\
\text { (Oxford, May 2019) }\end{array}$ & 2019 & 1 \\
\hline $\begin{array}{l}\text { 'Cooperative Organization and Agricultural } \\
\text { Innovation. The Dutch Sugar Beet Industry, } \\
\text { c. } 1890-1970 \text { ' }\end{array}$ & $\begin{array}{l}\text { Rural History Conference (Paris, } \\
\text { Sept. 2019); Utrecht Economic and } \\
\text { Social History Seminar (Utrecht, } \\
\text { Feb. 2019); Social, Economic, and } \\
\text { Demographic History Seminar } \\
\text { (Nijmegen, Jan. 2019); H2D2 } \\
\text { Seminar (Michigan, Dec. 2018); } \\
\text { Cambridge Graduate Seminar in } \\
\text { Social and Economic History } \\
\text { (Cambridge, Jan. 2018). }\end{array}$ & 2018-2019 & 1 \\
\hline $\begin{array}{l}\text { "No Protectionism of Prices, but } \\
\text { Protectionism of Knowledge": the } \\
\text { nineteenth-century origins of Dutch } \\
\text { agricultural innovation in a European } \\
\text { perspective' }\end{array}$ & $\begin{array}{l}\text { Rural History Conference (Leuven, } \\
\text { Sept. 2017); CAGE, EHES \& IAS } \\
\text { Summer School (Warwick, July } \\
\text { 2017); Posthumus Congress } \\
\text { (Nijmegen, June 2017); RHI seminar } \\
\text { (Wageningen, Oct. 2016). }\end{array}$ & $2016-2017$ & 1 \\
\hline \multicolumn{4}{|c|}{ C) Career related competences/personal development } \\
\hline $\mathrm{RHI}$ seminar organizer & $\begin{array}{l}\text { Rural and Environmental History } \\
\text { Group }\end{array}$ & $2017-2018$ & 2 \\
\hline Lecturer 'Sustainability Transitions' & $\begin{array}{l}\text { Rural and Environmental History } \\
\text { Group }\end{array}$ & 2017, 2019 & 2 \\
\hline Total & & & 35.8 \\
\hline
\end{tabular}

*One credit according to ECTS is on average equivalent to 28 hours of study load 


\section{Funding}

This research was funded by the Nederlands Agronomisch Historisch Instituut (NAHI), project number 2100909800 .

\section{Cover image}

Photograph of greenhouses in the village of Terbregge (currently part of Rotterdam), date unknown. The photograph is from the private collection of N.F.J. Zwarts. 



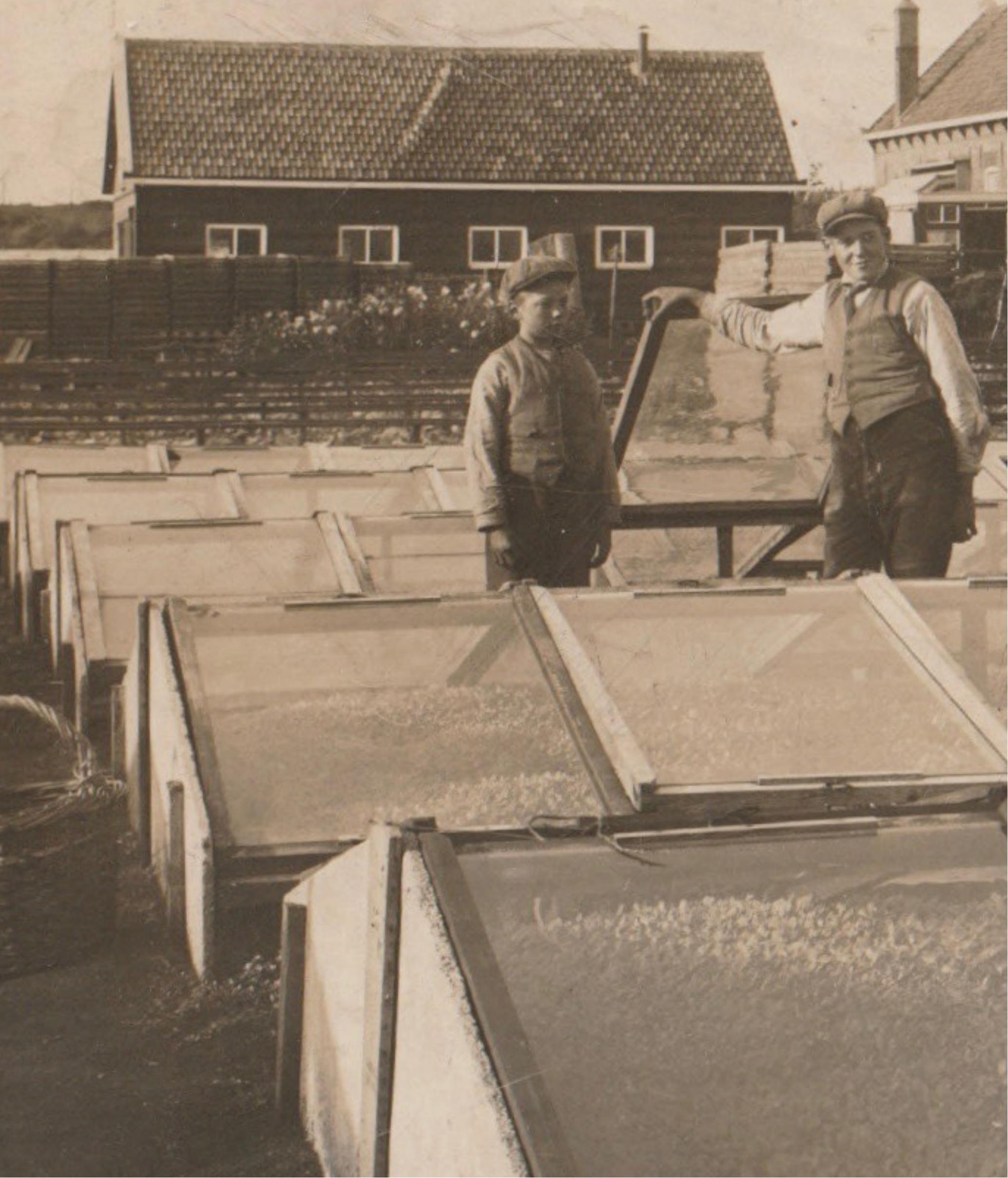

